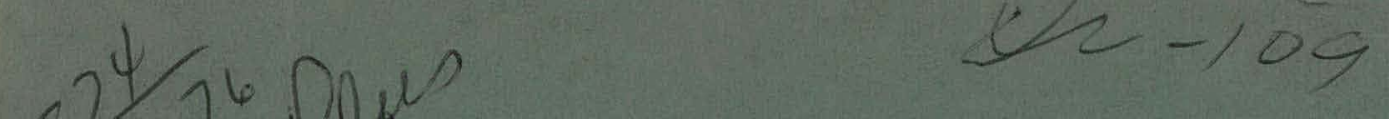

BNWL-1958

UC-12

\title{
A Survey of Materials and Corrosion Performance in Dry Cooling Applications
}

March 1976

Prepared for the Energy Research and Development Administration under Contract E(45-1):1830 


\section{DISCLAIMER}

This report was prepared as an account of work sponsored by an agency of the United States Government. Neither the United States Government nor any agency Thereof, nor any of their employees, makes any warranty, express or implied, or assumes any legal liability or responsibility for the accuracy, completeness, or usefulness of any information, apparatus, product, or process disclosed, or represents that its use would not infringe privately owned rights. Reference herein to any specific commercial product, process, or service by trade name, trademark, manufacturer, or otherwise does not necessarily constitute or imply its endorsement, recommendation, or favoring by the United States Government or any agency thereof. The views and opinions of authors expressed herein do not necessarily state or reflect those of the United States Government or any agency thereof. 


\section{DISCLAIMER}

Portions of this document may be illegible in electronic image products. Images are produced from the best available original document. 
NOTICE

This report was prepared as an account of work sponsored by the United States Government. Neither the United States nor the Energy Research and Development Administration, nor any of their employees, nor any of theif contractors, subcontractors, or their employees, makes any warranty, express or implied, or assumes ariy legal liability or responsibility for the accuracy, completeness or usefulness of any imformation, apparatus, product or process disclosed, or represents that its use would not infringe privately owned rights.

\author{
PACIFIC NORTHWEST LABORATORY \\ operated by \\ BATTELLE \\ for the \\ ENERGY RESEARCH AND DEVELOPMENT ADMINISTRATION \\ Under Contract E(45-1)-1830
}
Printed in the United States of America
Availabie from
National Technical Information Service
U.S. Department of Commerce
5285 Port Royal Road
Springfieid, Virginia 22751

Price: Printed Copy \$6.50; Mitrofiche $\$ 2.25$

EADARh Michitano -. 
BNINL-1958

UC -12

A SURVEY OF MATERIALS AND CORROSION

PERFORMANCE IN DRY COOLING APPLICATIONS

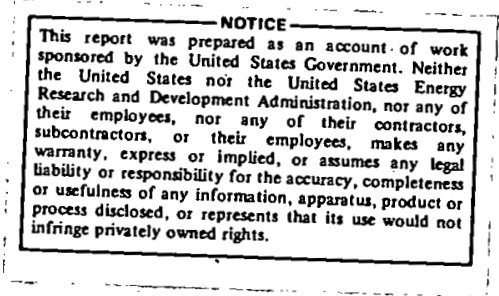

by

A. B. Johnson, Jr., D. R. Pratt and G. E. Zima

March 1976

Battelle

Pacific Northwest Laboratories

Richland, Washington 99352

DISTRRIBUTION OF THIS DOCUMENT IS UNLIMITED 
There is presently only one dry-cooled central power station in the U.S. However, the prospects that additional dry-cooled capacity will be needed in the future prompted a program sponsored by the Energy Research and Development Administration (ERDA), to assess the state-of-the-art and to develop dry cooling as an option for the utility industry. Battelle's Pacific Northwest Laboratories is program manager for the dry cooling tuwer program. [arly program action has centered on industrial contacts to derive the current philosophy, methodology and problem areas in dry cooling technology.

Battelle contacled a cross section of the U.S. dry cooling equipment industry and made visits to several operating dry-cooled power stations in Europe. This report addresses the construction materials and the scope of the successful performance and operational problems, emphasizing results from the U.S. survey. The results of the European survey are summarized in a separate report, which factors in a broader perspective regarding the operation of dry-cooled power stations.

The results of the survey indicate that U.S. industrial dry-cooled equipment functions with very few operational problems. The types of problems which occur were cataloged, including corroston, fall blade, fan motor, and gear box failures, freezing, hail damage and hot air recirculation. None of the potential problems were regarded as severe by the users.

Corrosion, while not a frequent problem, was the only problem which has resulted in shut downs for major repair. This occurred at one drycooled power station (Kugeley) and al d rew industrial air cooled instal= lations having polluted atmospheres. Correct siting and materials selection for large dry-cooled power stations will assure that corrosion is a minimal problem. To provide guidance for corrosion control, the report summarizes aqueous and air-side corrosiun aspects of candidate materials in dry cooling applications. The applications include piping, condensers, louvers, structures, and the air-cooled surfaces. 
Thousands of small air-cooled heat exchangers (dry coolers) are used in U.S. industrial applications. The large scale application which most nearly matches the temperature range of dry-cooled power stations, $45-60^{\circ} \mathrm{C}$ $\left(120-150^{\circ} \mathrm{F}\right)$, involves dry coolers for natural gas pipeline compressor engines. Six of the largest gas pipeline companies were surveyed, comprising 219 stations and 1542 coolers, which have operated up to 28 years. The coolers range in size from 1 to $50 \mathrm{M} \mathrm{Btu} / \mathrm{hr}$. The principal construction materials are aluminum fins, admiralty tubes and carbon steel headers; copper fins were used in some units.

These small dry coolers have an excellent record of reliability; they are on 1 ine $290 \%$ of the time, except where recent reductions in gas loads require shut downs. The large majority are sited at rural locations; approximately $10 \%$ of the coolers are in industrial, urban, or marine environments. Only two stations having aluminum-finned units have experienced severe air-side corrosion problems. One station located in a marine environment near a sulfur plant replaced four coolers after 13 years, due to intergranular attack on the aluminum fins. The second case occurred about 1960 and the failure mechanism is not clear. Aluminum fins have been examined from stations which operated 16 years and about 1.5 miles from the Gulf of Mexico and 18 years at a semiarid location in the Northwest. In both cases the maximum corrosion penetration from metallography was less than $12 \mu \mathrm{m}(0.5 \mathrm{mil})$. Copper-finned tubes had to be replaced by aluminum in sulfur-contaminated environments. It is importo remember that air-side corrosion generally occurs only when both moisture and corrosive atmospheric pollutants are present simultaneously. Fin fouling is minimized by annual or semiannual cleaning. Cleaning procedures include spraying with fire hoses and/or detergent solutions; steam cleaning or air lances are used at some sites.

Heat transfer fluids in the coolers are either inhibited water or water-glycol solutions. Corrosion from the coolant. side has not been an operational problem in pipeline dry coolers.

A survey of dry cooler performance in process applications indicated a corrosion failure rate substantially higher than that for compressor 
engine coolers because of chemically polluted local atmospheres and aggressive in-tube fluids. An oil company with 14 refineries in 7 countries experienced 23 corrosion failures in 625 dry coolers. The coolers consistently failed from interior corrosion by aggressive process solutions. Serious corrosion occurred on copper fins in sulfur-contaminated U.S. gas refineries. Examples of serious aluminum fin corrosion also have occurred in process applications. The air-side and process-side environments to which dry coolers are subjected in the process industry generally are more aggressive than would be encountered in typical power stations. Therefore. the failure rate and component life statistics from process coolers have limited value for predicting service lives of power station cooling tower materials.

Some industrial coolers operate with a combination of wet and drycooled modules. The potential for corrosion in these units is generally higher than in all-dry units because of moisture drift from the wet module and less effective chemistry control in the circulating water, compared to a closed cycle dry-cooled system.

Another option involves deluge r.noling, where water is sprayed or cascaded over the exterior surfaces of closed loop systems. Spray systems which have operated since 1958 have been inspected. Severe corrosion and deposition have occurred occasionally, hut the systems are reported to operate acceptably if the water is properly treated. The concept of a water cascade intermittently passed over exterior fin surfaces to augment cooling during hot weather is under investigation in the Ivanavo plant in Russia, based on Hungarian pilot studies. Corrosion and deposition will be studied as a function of delugate chemistry.

Large dry-cooled power stations (plants $>100$ MWe) first came on line in 1961; approximately 10 of the large plants were in operation by 1975, mainly in Europe. Smaller stations came on line as early as 1939. The internal cooling tower circuits are exposed to steam and condensate (direct cycle) or only to condensate (indirect cycle). Most direct cycle power plants are in Europe and they have been built by one European manufacturer 
who employs steel tubes and galvanized steel fins. No unsatisfactory corrosion of the galvanized steel fins have been reported for the three direct cycle power plants included in this survey. Unlike the large indirect cycle plants, these direct cycle units are elevated high off the ground (up to $40 \mathrm{~m}$ ) and have no wet cooling towers in the immediate vicinity discharging corrosive drift and moisture onto their finned surfaces. The indirect cycle plants are constructed with aluminum fins and tubes. Aqueous and air-side corrosion has been acceptable at most locations. Serious air-side corrosion occurred at the Rugeley plant in England, resulting from a combination of a contaminated environment, crevices on the plate-type aluminum fin assembly, and horizontal fin orientation, which maximized accumulation of moisture and contaminants in the highly humid atmosphere. At the Ibbenbüren plant, where the dry tower is located alongside a wet tower and the station's coal storage pile, severe fouling by coal dust occurred at some locations on the plate-type aluminum fins. Preliminary examinations suggest that aluminum corrosion is occurring under the caked coal dust. In coal fired plants, the dry tower location must be carefully chosen in relation to existing wet cooling towers, coal storage piles and prevailing winds. No serious aqueous corrosion problems have been reported in the operating power stations. However, steel corrosion product transport was sufficiently severe in the Russian Razdan plant to cause plant personnel to contemplate aluminizing the steel surfaces and consider a major change in water chemistry.

There is a large body of atmospheric corrosion literature which includes information relevant to dry cooling tower candidate materials. However, the data apply to dry-cooled plant finned tubes only during shut down conditions, when the metal is at ambient temperature. While the plant is on-line the finned tube temperatures are above the dewpoint, and the corrosion-inducing motsture effects will be low except when there is fog, rain or snow. On the other hand, corrosive effects of some contaminants are not well-defined in the dry cooling tower temperature regime. 
While the performance of small dry coolers in natural gas pipeline compressor engine service indicates that dry towers can be expected to operate satisfactorily in rural environments, there are essentially no data, based on metallurgical examinations, which precisely define air-side corrosion rates in the dry cooling tower operating regime as a function of the air-side environment. Studies are needed which correlate corrosion under ambient and dry cooling conditions. Systemmatic assessment of corrosion environments at sites where dry-cooled plants are to be built appears prudent. With judicious siting, air-side corrosion will be minimal. However, for plants with large capital investments and high downtime costs, aqueous and air-side corrosion monitoring should extend over plant life, to detect possible changes in corrosiun of the large heat transfer surfaces before extensive damage occurs, providing an opportunity for timely corrective action.

Some aqueous corrosion studies have direct application to dry cooling system operating regimes, including the condenser, piping and air-cooled heat exchanger. Principal areas where additional definition would be of value are: rates of corrosion product transport and deposition as a function of a system design and water chemistry; the effectiveness of the so-called "neutral" method of water chemistry control for systems employing both aluminum and steel; limits of operation to avoid specific failure mechanisms such as corrosion fatigue, stress corrosion cracking and erosion corrosion.

Operating standards or guides for cooling equipment design and operation already exist. However, additional guides may be desirable for drycooled plants to define procedures which avoid serious corrosion problems. Regarding air-side corrosion, the standards should address questions such as materials selection as a'function of environment; optimum cleduing and layup procedures; corrosion monitoring; and methods to minimize atmospheric corrosion of ancillary equipment. Water-side operating standards and guides should define water chemistry control requirements for the cooling water loop as a function of material and plant design; methods to clean 
water-side surfaces if required; acceptable materials combinations; interactions of design factors (e.g., stress levels and heat treatments) and corrosion.

\section{Conclusions}

- The performance of dry coolers at gas pipeline compressor stations suggests that dry-cooled equipment can function satisfactorily for at least 30 years in clean, rural atmospheres and in some industrial environments.

- Aluminum finned dry cooler performance in the process industry has limited value for predicting weathering performance in power plant application. Process plants of ten have chemically contaminated local atmospheres that are corrosive to metals. In addition, their tubes operate with aggressive tube-side fluids at higher temperatures, and their operational histories frequently differ from that of dry towers. However, process plants are the largest users of aluminum finned dry coolers.

- Observations from the operating dry-cooled power stations suggest that corrosion has been a minimal problem at most locations. However, additional metallographic evidence would be useful in assessing quantitatively both air-side and water-side corrosion as a function of plant siting, design, materials of construction, operating conditions and time. The operating plants are a potentially valuable source of quantitative information, and systemmatic corrosion sampling prograllis should be instituted.

- Construction materials for dry cooling towers in operating power plants include three principal classes of materials for finned assemblies:

- aluminum tubes and aluminum fins

- steel tubes (externally galvanized) and aluminum fins

- steel tubes and galvanized steel fins.

Copper-base alloy tubes and aluminum fins are used extensively in small industrial aerial coolers, but the copper. alloys are not 
economically competitive with aluminum and steel for construction of dry cooling towers in large power plant applications.

Contact condensers and piping which carry steam and steam condensate are constructed with mild steel. Louvers and panels generally are either steel (painted), aluminum, or galvanized steel.

- Aluminum has performed satisfactorily in thousands of industrial air coolers and in a few dry cooling towers. It has performed satisfactorily for lnng periods with few exceptions, these being in a few contaminated atmospheres where chlorides and/or sulfur compounds were major contaminants. Some air-side corrosion has occurred on European galvanized steel dry cooling towers exposed in industrial environments, but has not required plant shutdowns. In relatively clean environments, galvanized steel corrosion has not been a problem.

Water-side corrosion problems have been minimal in operating industrial coolers and dry cooling towers. Some mild cases of corrosion product transport have been reported.

- Design factors such as crevices, horizontal fins, imbedded fins and wrap-on fins with dissimilar metals between the fins and tubes tend to promote corrosion under adverse conditions but appear to be acceptable at locations where atmospheres are clean and dry.

- Corrosion of dry-cooled fin surfaces can be minimized with organic coatings, but with substantial economic penalties. There is too little experience to assure that the cuatings will last for 30 year plant lives without considerable maintenance, which would be difficult on finned tubes. If a corrosive environment is anticipated, one vendor suggests the alternative of using thicker fins or fins clad with an aluminum-zinc alloy. 


\section{TABLE OF CONTENTS}

SUMMARY AND CONCLUSIONS ................. $\ldots$ i

LIST OF TABLES . . . . . . . . . . . . . . . . . xi

LIST OF FIGURES . . . . . . . . . . . . . . . xiv

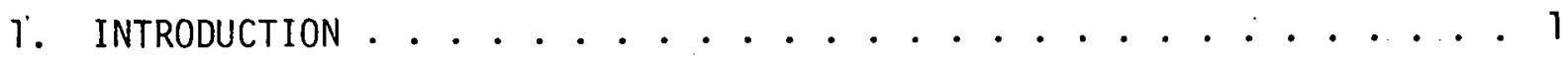

1.1 Present Scope of Dry Cooling . . . . . . . . . . 2

1.2 Significance of Corrosion in Dry-Cooled Power Stations . . . . 5

2. U.S. INDUSTRIAL EXPERIENCE WITH AIR COOLED EQUIPMENT . . . . . 7

2.1 Gas Pipeline Compressor Engine Coolers . . . . . . . . . . 7

2.1 .1 Cooling Concepts .............. . . 9

2.1.2 Scope of Compressor Engine Survey . . . . . . . . 10

2.1.3 Water Chemistry . . . . . . . . . . . . 10

2.1.4 Corrosion of Compressor Engine Coolers ...... 13

2.1 .5 Air-Side Corrosion ............. . 14

2.1.6 Water-Side Corrosion . . . . . . . . . . 17

2.1 .7 Freezing . . . . . . . . . . . . 18

2.1 .8 Recirculation . . . . . . . . . . . 18

2.1.9 Fouting ..................... 19

2.1.10 Miscellaneous 0perational Problems . . . . . . . . 19

2.2 Dry Coolers in the Process Industry . . . . . . . . . 20

2.2.1 Dry Cooler Performance in Petroleum Refineries . . . . . 20

2.2.2 Dry Cooler Performance in Natural Gas Processing Plants . . 20

2.3 Materials Performance in Wet/Dry Coolers . . . . . . . . 26

2.3.1 Wet/Dry Cooling Towers.............. . 26

2.3.2 Deluge Systems. . . . . . . . . . . . . 28

2.4 Industrial Steam Condensers. . . . . . . . . . . . . . 30

2.5 Discussions with Dry-Cooled Equipment Vendors. . . . . . . 31

2.5.1 Discussions at Hudson Products, Inc. . . . . . . 32

2.5.2 Discussions at Marley . . . . . . . . . . . . . 33

2.5.3 Discussions at Ecodyne and MRM. . . . . . . . . 35

3. CORROSION BEHAVIOR IN DRY-COOLED POWER GENERATING STATIONS . . . . 37

3.1 Direct Cycle Plants. . . . . . . . . . . . . . 37

3.1.1 Steam/Water Corrosion Performance . . . . . . . . 38 
3.1.2 Air-side Corrosion ............. . . 40

3.2 Indirect Cycle Plants ................ . . 40

3.2.1 Aqueous Corrosion . . . . . . . . . . . . . 42

3.2.2 Air-Side Corrosion .............. . . 45

4. SURVEY OF PUBLISHED CORROSION DATA ............. . . . 47

4.1 Water-Side Corrosion of Candidate Materials . . . . . . . 48

4.1 .1 Candidate Materials .............. . . 48

4.1 .2 Aluminum Base Allnys . . . . . . . . . . . . . 50

4.1.2.1 General Corrosion Behavior . . ....... 50

4.1.2.2 Efrect of Temperature ........... 52

4.1.2.3 Effect of $\mathrm{pH} \ldots \ldots . . . . . . .53$

4.1.2.4 Corrosion Mechanisms . . . . . . . . . . 54

4.1 .3 Copper-Base Alloys ................ . . 63

4.1.3.1 General Corrosion Behavior......... 63

4.1.3.2 Effect of $\mathrm{pH} . \ldots . . . . . . .666$

4.1.3.3 Corrosion Mechanisms . . . . . . . . 67

4.1 .4 Iron-Base Alloys . . . . . . . . . . . . . 82

4.1.4.1 General Corrosion Behavior. . . . . . . . . . 82

4.1.4.2 Corrosion Mechanisms ............ . 88

4.2 Atmospheric Corrosion of Candidate Materials . . . . . . . 97

4.2.1 Candidate Materials ... . . . . . . . . . . . 97

4.2.2 Relevance of Atmospheric Corrosion Data . . . . . . . 97

4.2.3 Atmospheric Corrosion Characteristics . . . . . . . 98

4.2.4 Aluminum Alloys ............. . . 106

4.2.4.1 Atmospheric Corrosion Data--Aluminum Alloys . . . 107

4.2.4.2 Corrosion Mechanisms . . . . . . . 112

4.2 .5 Iron-Base Alloys ................. 113

4.2.5.1 Corrosion Behavior--Steels . . . . . . . 115

4.2.5.2 Corrosion Mechanisms--Stee1s . . . . . . . 117

4.2.6 Copper-Base Alloys . . . . . . . . . . . . . . 122

4.2.6.1 Atmospheric Corrosion Dáta--Copper Alloys . . . . 122

4.2.6.2 Corrosion Mechanisms--Copper Alloys ... . . . 128 
4.2.7 Galvanized Steel . . . . . . . . . . . 130

4.2.7.1 Atmospheric Corrosion Data--Gaivanized Steel . . . 131

4.2.7.2 Corrosion Mechanisms--Galvanized Steel . . . . . 133

5. DRY COOLING TOWER CORROSION REFERENCES ............ 135

6. DRY COOLING TOWER CORROSION RESEARCH . . . . . . . . . . . 138

7. FUTURE DEVELOPMENT OF A DRY COOLING TOWER CORROSION DATA BASE . . 14.7

8. REFERENCES . . . . . . . . . . . . . . . . . 144

9. ACKNOWLEDGEMENTS . . . . . . . . . . . . 151

10. APPENDICES . . . . . . . . . . . . . . . 152

10.1 Dry Cooler Operating Experience ........... 152

10.2 Cost of Candidate DCT Materials . . . . . . . . . . 155

10.3 Water Treatment Costs . . . . . . . . . . 158 


\section{LIST OF TABLES}

1 Compressor Engine Dry Cooler Design and Performance Data $\quad \frac{\text { Page }}{9}$

2 Compressor Engine Dry Cooler Summary 12

3 Comparison of Common and Unitized Coolants. 13

4 Summary of Air-Side Corrosion--Compressor Engine Coolers 15

5. Dry Cooler Performance in Petroleum Refineries , 21

6. Temperature Limits for Various Finned Tube Designs 22

7 Dry Cooler Performance in One Company's Gas Processing Company 23

8 Materials in Conventional Wet/Dry Coolers 27

9 Power Plants with Direct-Cycle Cooling 37

10 Water Chemistry at Operating Direct-Cycle Plants 39

11 Power Plants with Indirect Cycle Cooling 40

12 Water Chemistry at Operating Indirect-Cycle Plants 41

13 Candidate Materials for Dry-Cooled Systems. 49

14 Examples of Aluminum Alloys Used for Tubular Heat Exchangers 50

15 Logarithmic Slopes and Intercepts for Corrosion of 1100 Aluminum in Water

16 Internal Surface Area and Volume, 1100 MW Fossil Plant Circulating Water System

17 Dissolution of Gibbsite in Pure Water, $25^{\circ} \mathrm{C} \quad 62$

10 Copper Alloys Uscd for Tubular Heat Exchangers 64

19 Maximum Allowable Velocities of Aerated Fresh Water for Copper Alloys in Heat Exchanger Service 74

20 Corrosion Product Release from Copper Alloys 78

21 Effect of Velocity and Water Purity on Corrosion Product Release from Carbon Steel

22 Type 304 Stainless Steel Corrosion and Release in Neutral, High-Purity, Flowing Water

23. Solubilities of Gases in Water. 101

24 Electrode Potential of Várious Metals and Alloys in ChloridePeroxide Solution

25 ASTM Chemical Requirements for Weathering-Type Steels 116

26 Chemical Composition of 12 Steels with Best Atmospheric Corrosion Resistance 
27 Corrosion Performance of Aluminized Steel Versus Carbon Steet 1

118

28 Corrosion Performance of Aluminum-Silicon Alloy Coating Versus Galvanized Coatings in Various Atmospheres

29 Copper Alloys Tested for Atmospheric Corrosion 123

30 Life Expectancy of Galvanized Steel Sheets

132 


\section{LIST OF FIGURES}

Page

IA Direct Cooling Tower Steam Condensing System 3

IB Indirect Dry Cooling Tower Steam Condensing System with Mechanical-Draft Tower

3 Dry Coolers--Unitized Systems--Used to Cool Compressor Engine $0 i 1$ and Jacket Water; Installed 1958

4 Dry Cooler-Common System--Used to Cool Compressor Engine $0 \mathrm{i} 1$ and Jacket Water; Installed 1952/3

5 Dry Cooler in Sulfur-Free Environment (Company E) 24

6 Dry Cooler in Sulfur-Contaminated Environment (Company E)

7 Air-Cooled Steam Condenser (Company E) 31

8 Effect of the $\mathrm{pH}$ Value (Hydrazine Content) on Aluminum in the Circulating Water, Ibbenbüren

9 Corrosion of Aluminum Alloy 1100 in Continuously Refreshed Distilled Water

10 Corrosion of Aluminum Alloy 1100 in 0xygen-Saturated Solutions at $50^{\circ} \mathrm{C}$

11 Effect of pH of Distilled Water on the Weight Loss of Aluminum Alloy 3004-H14 Specimens Exposed at $60^{\circ} \mathrm{C}$ for One Week

12 Effect of $\mathrm{pH}$ on Corrosion of Aluminum Alloy $1100-\mathrm{Hl} 4$ by Various Chemical Solutions

13 Weight Loss of Aluminum Alloy 1100 in Continuously Refreshed Water at $70^{\circ} \mathrm{C}$

$14 \mathrm{pH}$ Dependence of the Solubility of Gibbsite 62

15 Relative Effect of $\mathrm{pH}$ on the Rate of Corrosion of Copper Alloys

16 Effect of Velocity on the Maximum Erosion Corrosion Penetration Rate for Copper Tube Exposed to Sodium Zeolite Softened, Aerated Water at Selected Temperatures

17 Effect of Velocity on the Maximum Erosion Corrosion Penetration Rate for Copper Tube Exposed to Sodium Zeolite Softened, Cold Vacuum Deaerated Water at Selected Temperatures

18 Effect of Velcoity on the Maximum Erosion Corrosion Penetration Rate for Admiralty Brass Tube Exposed to Sodium Zeolite Softened, Aerated Water at Selected Temperatures

19 Effect of Velocity on the Maximum Erosion Corrosion Penetration Rate for 90/10 Copper Nickel Exposed to Sodium Zeolite Softened, Aerated Water at Selected Temperatures 
20 Release of Copper Corrosion Product to Static, Unrefreshed Deionized Water

$21 \mathrm{pH}$ Dependence of the Solubility of Hydrated Copper Oxide

22 Dependence of the Corrosion Rate of Carbon Steel on $\mathrm{pH}$

Maintained by Ammonia

23 Dependence of the Corrosion Rate of Carbon Steel on Water Purity in Oxygen-Saturated Water

24 Dependence of Carbon Steel'Corrosion Rate on 0xygen Concentration in High-Purity Water

25 Corrosion Rate of Carbon Steel in Neutral, High-Purity Water at Very Low Dissolved Oxygén Concentration

26 Relationship of Number of Cycles of Failure to Stress for Steels Subjected to Cyclical Stress

27 Variation of the Corrosion Rate of Mild Steel with Flow Rate Up to $1.0 \mathrm{~m} / \mathrm{sec}$

$28 \mathrm{pH}$ Dependence of the Solubility of $\mathrm{Fe}(\mathrm{OH})_{2}(\mathrm{~s})$ at $25^{\circ} \mathrm{C} \quad 95$

$29 \mathrm{pH}$ Dependence of the Solubility of $\mathrm{Fe}(\mathrm{OH})_{3}(\mathrm{~s})$ at $25^{\circ} \mathrm{C}$

30 Characteristic Kinetic Corrosion Curves for Atmospheric Corrosion of Various Metals

31 Effect of Increasing Humidity on Mild Steel with Various Atmospheric Contaminants

105

32 Effect of Initial Exposure Conditions on Subsequent Corrosion of Copper

33 Maximum Depths of Attack of Aluminum Alloy 3003-H14 at 10 and 20 Year Periods Superimposed on Curves Obtained on Related Alloys Exposed at New Kensington

34 Rate of Weathering of Aluminum Alloy 3003-H14 in Industrial Environments as Measured by Loss of Tensile Strength

35 Measured Depths of Attack of Aluminum Alloy 3003-H14 at 10 and 20 Year Periods Superimposed on Curves Obtained on Related Alloys Exposed at Point Judith, RI

36 Rate of Weathering of Aluminum Alloy 3003-H14 in Seacoast Environments as Measured by Loss of Tensile Strength

37 Breakthrough Potential of Aluminum (99.99\%) in Different Halide Solutions, and Open Circuit Corroslon Potential in Chloride Solutions Containing $5 \mathrm{ppm} \mathrm{Cu}^{++}$

38 Comparative Corrosion of Steels of Varying Thicknesses, Industrial Atmosphere, Kearney, $\mathrm{NJ}$

39 Schematic Representation of the Rust Layers on Steels After Exposure to the Atmosphere for Long Periods 
40 Effect of $\mathrm{pH}$ on Corrosion of Iron in Aerated Soft Water at Room Temperature

41 Corrosion of Copper Alloys in Atmospheric Tests _. 124

42 Corrosion of Copper Alloys from Atmospheric Tests $\quad 125$

43 Effect of $\mathrm{SO}_{2}$ Concentration on Copper Corrosion at Various Relative Humidities

44 Curves of Anodic Polarization of Copper in $0.1 \mathrm{~N} \mathrm{Na}_{2} \mathrm{SO}_{4}$ and $0.1 \mathrm{~N}$ $\mathrm{NaCl}$ Solutions of Different Thickness

45 Service Life of Zinc Coatings Versus Zinc Thickness

46 Graphical Presentation of Empirical Equation Showing the Effects of Time of Panel Wetness and Atmospheric Sulfur Dioxide on the Corrosion of Iinc

47 Equivalence Between Sulfur Dioxide Taken Up by -Zinc and Atmospheric Corrosion of Zinc at Stuttgart 


\section{MATERIALS PERFORMANCE AND CORROSION}

IN DRY COOLING APPLICATIONS

\section{STATE-OF-THE-ART SUMMARY}

\section{INTRODUCTION}

Battelle's Pacific Northwest Laboratories (PNL) is program manager for an Energy Research and Development Administration (ERDA) program to assess and develop dry cooling as an option for the electrical generating industry. Presently, steam is condensed in large power plants by once-through cooling from lakes or streams or, increasingly, in wet towers, which discharge water to the atmosphere by evaporation. Environmental restrictions, increasing water costs, and decreasing availability of cooling water portend that closed cycle dry cooled steam condensers may become attractive at some U.S. locations before 1990. (1)

An early phase of the Dry Cooling Tower Program involved development of a working relationship with various sectors of U.S. industry having direct or potential interest in dry cooling. Results of the early contacts were reported, ${ }^{(2)}$ including perceptions of industry regarding the major problems in dry cooling tower technology.

Subsequent industrial contacts have focused on defining operating experience with dry cooled equipment, including the scope of successful performance and the reasons for equipment failures.

This report summarizes materials performance in a cross section of U.S. dry-cooled installations. It also addresses projections of corrosion performance in dry cooling tower applications, based on the U.S. industrial contacts, corrosion and water chemistry information from selected power stations, and the pertinent literature.

A subsequent report will summarize information from selected foreign dry-cooled central power stations. The surveys update and complement earlier surveys. $(3,4)$ 
The surveys concentrate on state-of-the-art dry cooling concepts. The Program is actively involved with assessments of advanced concepts, such as ammonia cycles, fluidized bed concepts and plastic heat exchangers. However, materials aspects of those systems are beyond the scope of this report.

In general, both metric and English units will be given; where extensive revision of tables or graphs would be required, the original units will be used.

The excellent cooperation of numerous industrial contacts is gratefully acknowledged.

\subsection{PRESENT SCOPE OF DRY COONI TNG}

About two dozen electrical generating plants in Europe, Asia and South Africa use air cooled steam condensers. ${ }^{(3,5)}$ The plants have electrical outputs ranging from 4 to 220 MWe. A small unit in the German Ruhr began operation in 1939. (5) A 13 MWe unit in Luxemburg has operated since 1956. The normal temperature range in the cooling towers is $50-65^{\circ} \mathrm{C}\left(120-150^{\circ} \mathrm{F}\right)$.

Two major dry-cooled power plant designs are used in the foreign plants.

- The direct system, which involves transport of steam from the turbine outlet to the air-cooled, tower, where it condenses and returns to the boiler as condensate; (Figure $1 A$ )

- The indirect system, which involves steam condensation in a direct contact condenser, which sprays high quality condensate into the steam to condense it; most of the heated condensate is pumped to the dry cooling tower to dissipate the heat absorbed from the steam; the remaining condensate returns to the boiler via the feedwater circuit (Figure 1B).

A third option, now being installed at the Schmehausen ${ }^{(\sigma)}$ and Grootvlei plants, is the indirect cycle with a standard surface condenser. (7) Steam is condensed in the surface condenser and the condensate is recycled to the boiler. An independent cooling circuit on the secondary side carries heat to the cooling tower for release through the finned tubes. 


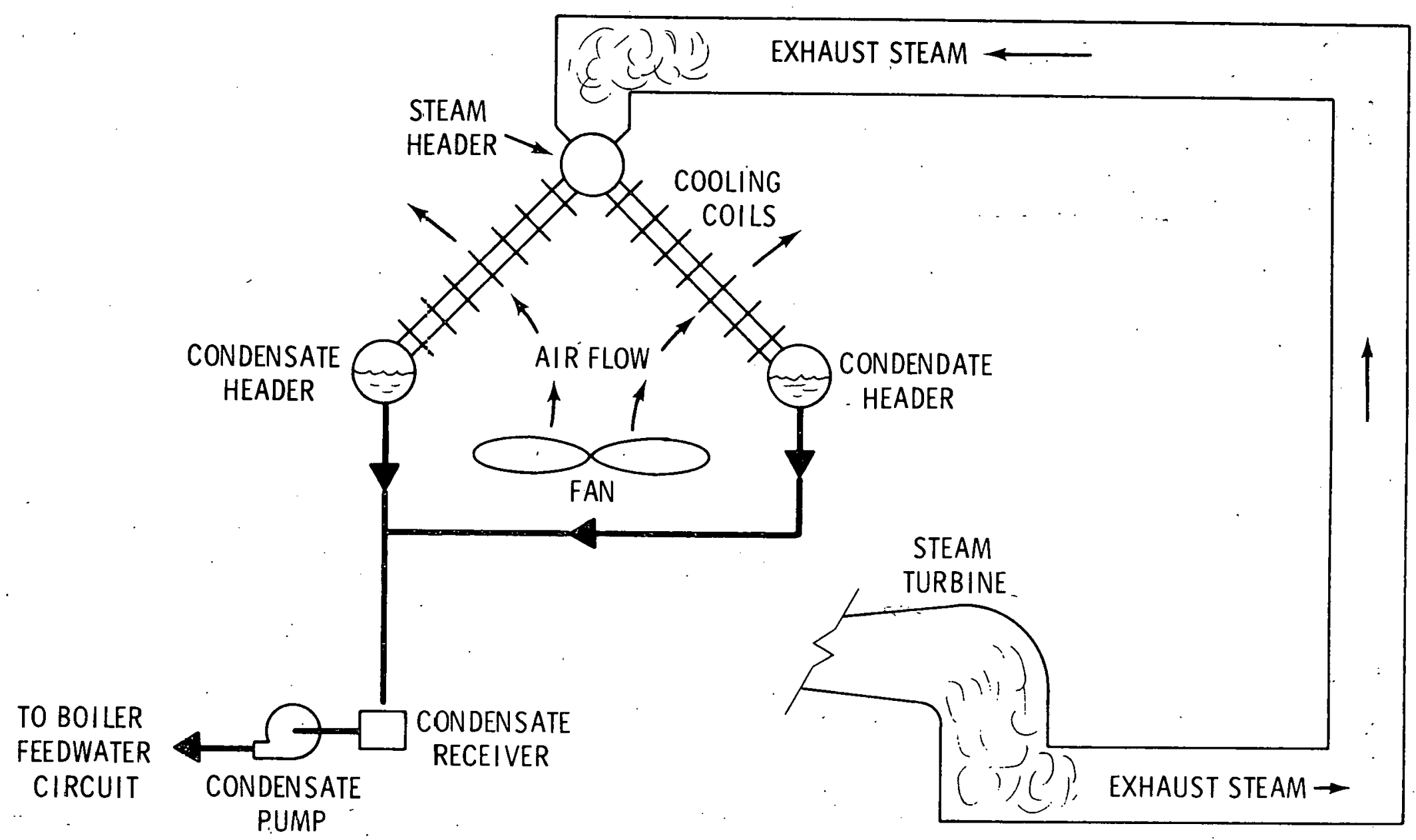

FIGURE 1A. Direct Cooling Tower Steam Cöndensing System (3) 


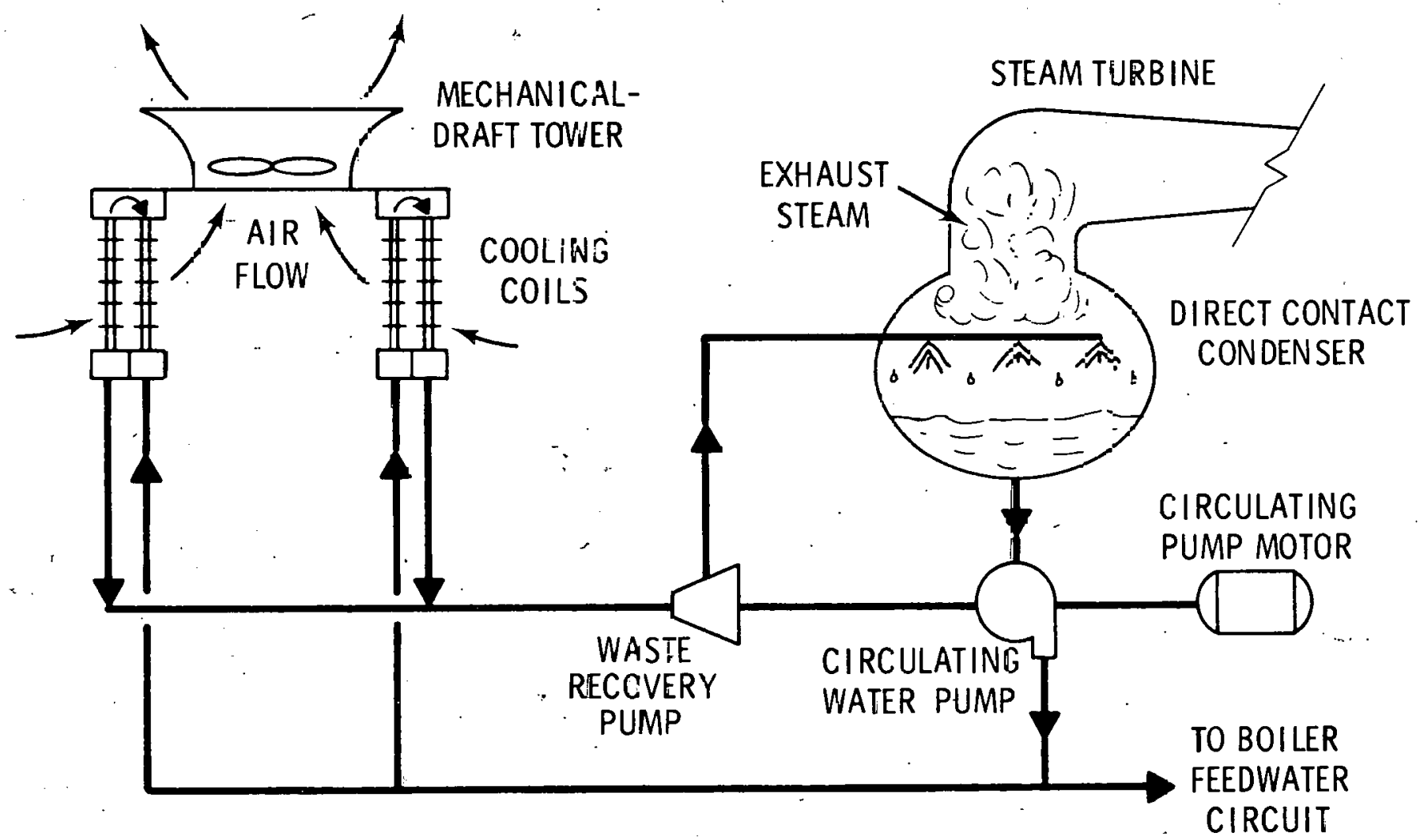

FIGURE 1E. Indirect, Dry Cooling Tower Steam Condensing System with Mechanical-Draft Tower (3) 
The Neil Simpson (Wyodak) Plant at Gillette, Wyoming is the only U.S. dry-cooled central power station. ${ }^{(3)}$ It is a direct-cooled coal fired mine mouth station located in a region with a severely limited water supply. There are two air-cooled units at Wyodak, a 3-MWe generator, operated since 1962, and a 20-MWe unit, operated since 1969. A 330-MWe plant under construction at Wyodak will be the world's largest single dry-cooled unit, with operation planned for 1978 . Some small U.S. industrial power generators also use air-cooled steam condensers. All power plants currently using dry cooled condensers are fossil-fired. However, application of the concept to nuclear plants appears feasible by using the indirect method with a surface condenser, to isolate radiation from the tower.

Thousands of small air-cooled units provide cooling for various industrial processes in the U.S. and elsewhere. The industrial coolers are constructed with banks of finned tubes cooled by fan-driven air streams. Typical applications include cooling of chemical process streams, large water cooled compressor engines and compressed gases. The industrial units are technically known as air-cooled heat exchangers but are referred to as air coolers by the process industry and as dry coolers or dry towers by the power industry. Some industrial units utilize the wet/dry concept, which combines evaporative and nonevaporative components in the same cooler.

The industrial units provide cooling over a wide range of inlet and outlet temperatures. Temperatures of $400^{\circ} \mathrm{C}\left(750^{\circ} \mathrm{F}\right)$ and higher are not uncommon. Also, many of the dry coolers are exposed to aggressive process solutions, which result in much higher failure rates from corrosion than would occur in units exposed to steam condensate at relatively low temperatures. Therefore, selectivity is required in relating industrial dry cooler experience to expected performance of dry towers in power stations.

\subsection{SIGNIFICANCE OF CORROSION IN DRY-COOLED POWER STATIONS}

Corrosion was identified in the initial survey ${ }^{(2)}$ as a, potentially costly factor which needs to be assessed and minimized in dry-cooled installations. Corrosion has not been a major problem in dry-cooled equipment, but some corrosion failures have occurred because of polluted 
atmospheres. In large (1000 MWe) electrical generating stations, outages cost the utility between $\$ 750,000$ and $\$ 1 M^{(8)}$ per day. With proper siting, material selection, and water chemistry control, outages due to corrosion of the cooling tower are not likely. Even if replacement of tower components is required, it should be possible to accomplish on a modular schedule, which would avoid total plant shutdown.

Surface condenser corrosion has caused outages in generating plants using once-through cooling. In dry-cooled plants using surface condensers, the closed loop between the condenser and the cooling tower offers the prospect of a controlled, relatively benign water chemistry, which should minimize shutdowns due to condenser corrosion. Direct. cycle cooling towers and indirect towers using contact condensers will be subject only to the relatively low corrosion rates characteristic of low temperature steam and steam condensate, given proper materials selection and water chemistry control. 


\section{U.S. INDUSTRIAL EXPERIENCE WITH AIR-COOLED EQUIPMENT}

This survey was undertaken to assess the scope of successful drycooled equipment performance and the types of problems which have occurred in U.S. installations. The survey was weighted toward natural gas pipeline compressor stations because they appear to represent the large scale U.S. industrial application which most nearly matches the temperature regime in dry-cooled power plants. Air-side experience from dry coolers used in process industries has some relevance, but the incidence of failure is relatively high (about 3 percent) caused principally from attack on internal surfaces by hot, aggressive process solutions.

Most of the industrial coolers circulate liquids through the finned tubes. However, dry coolers are used to condense steam in some industrial applications such as waste heat boilers and small power plants.

Information for the survey was obtained through questionnaires, discussions, on-site inspections and by some metallurgical examinations of specimens from failed and unfailed dry-cooled equipment.

\subsection{GAS PIPELINE COMPRESSOR ENGINE COOLERS}

Natural gas transmission companies require large compressor engines to provide gas transport through the regional and transcontinental pipelines. Air-cooled equipment provides cooling for the engine jacket water and lubricating oil. The compressor stations are located at 60-130 mile intervals along the major pipelines. Figure 2 shows the network of principal gas pipelines in the U.S. Dry cooler performance information was requested from several of the largest gas pipeline companies. Responses were received from companies with pipelines extending from Texas and Louisiana to the Northeastern States, in Florida, California, the Pacific Northwest, and the Rocky Mountain States. 


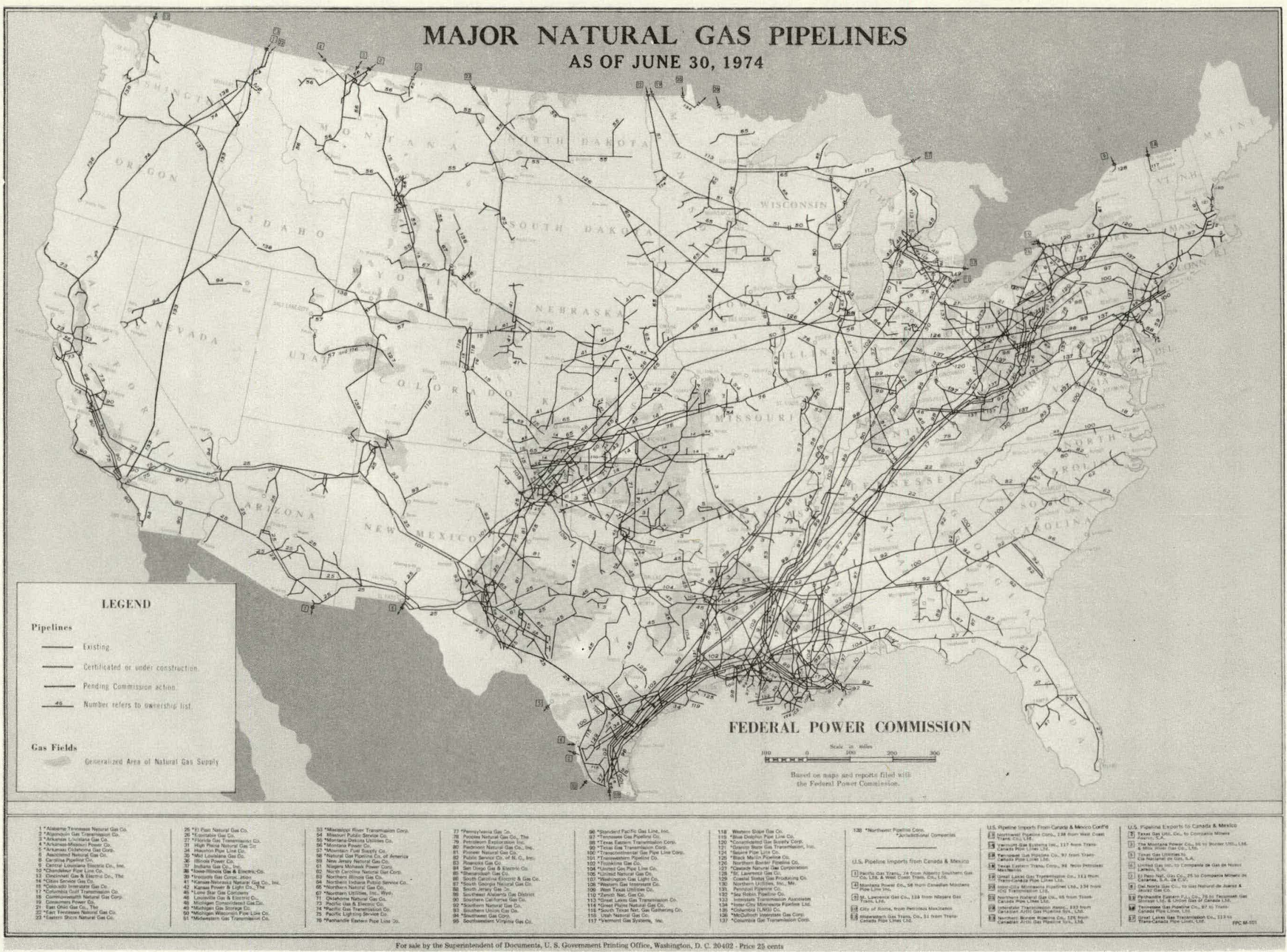

FIGURE 2. Major U.S. Natural Gas Pipelines 
Two types of engines are used at the compressor stations: reciprocating ( 1100 to $7500 \mathrm{hp}$ ) and gas turbine ( 1100 to $10,500 \mathrm{hp})$. The compressor engine coolers are constructed with banks of finned tubes. Figure 3 shows a typical installation; the banks of tubes are typically four tubes deep and are $\sim 3.7$ meters ( $12 \mathrm{ft}$ ) above ground level. The finned tube sections are of various sizes, but are typically $10 \mathrm{~m}(30 \mathrm{ft})$ long and $2.7 \mathrm{~m}(8 \mathrm{ft})$ wide. Fin designs include solder-bonded, wrap-on, embedded, extruded and plate fin designs.

\subsubsection{Cooling Concepts}

Cooling water circulates to the engine cooling jacket and oil cooler in closed loops. Fans drive air across the finned tubes to provide cooling. Table 1 shows typical design and operating parameters for the recent generation of compressor engine dry coolers.

\section{TABLE 1. Compressor Engine Dry Cooler Design and Performance Data}

$\begin{array}{ll}\text { Heat Exchange Rate, Btu/hr } & 1,000,000-50,000,000 \\ \text { Total Fluid Entering, } \mathrm{Tb} / \mathrm{hr} & 200,000-2,000,000 \\ \text { Inlet Temp, }{ }^{\circ} \mathrm{F} & 125 \text { (Typical) } \\ \quad \text { Outlet Temp, }{ }^{\circ} \mathrm{F} & 115 \text { (Typical) } \\ \text { Pressure Drop, psi } & \sim 5 \text { psi } \\ \text { Air Flow } 1 \mathrm{~b} / \mathrm{hr} & 700,000-6,000,000 \\ \text { Air Temp. } & 105 \text { (Typical) } \\ \quad \text { Inlet Temp, }{ }^{\circ} \mathrm{F} & 113 \text { (Typical) } \\ \quad \text { Outlet Temp, }{ }^{\circ} \mathrm{F} & 100-150\end{array}$


Two concepts are used for the compressor engine coolers: common and unitized. The common system employs a single bank of coolers servicing a number of compressor engines (Figure 4). In the unitized concept, each compressor engine has its own auxilliary systems, including the dry cooler (Figure 3 ). The unitized concept is predominant in recent installations, since it provides more flexibility in station operation. Water chemistries in the two systems are compared in the following section.

\subsubsection{Scope of Compressor Engine Survey}

Table 2 summarizes the numbers of slalions and coolers included in the compressor station survey. Further information reydrding results of a questionnaire survey are given in Appendix A. Approximate average cooler ages ranged from 15 to 22 years for the six companies shown in Table 2 . Maximum cooler ages were 19 to 28 years. The predominant tube construction material is admiralty brass; headers and piping are constructed of carbon steel. The vast majority of the coolers have aluminum fin material; none are made of galvanized steel. A small fraction of the coolers have had copper fins. Some coolers have extruded aluminum fins (6063 alloy); steel liners (A214 a110y) serve as conduits for the coolant.

\subsubsection{Water Chemistry}

Water chemistries for the common and unitized compressor engine cooler designs are compared in Table 3. The cuolants operate with inlet temperatures of $50-105^{\circ} \mathrm{C}$ and outlet temperatures of $45-75^{\circ} \mathrm{C}$. Most installations operate in the lower region of the temperature ranges, $265^{\circ} \mathrm{C}$ inlet, $245^{\circ} \mathrm{C}$ outlet.

Although the coolers operate in closed cycles, there are occasional needs to dispose of the coolants. Due to emerging restrictions on chromium releases, corrosion inhibitors which do not contain chromates are being tested. One company is testing nitrate inhibitors at four stations.

The water chemistries in the compressor engine coolant systems are not directly relevant to direct cycle dry cooled plants and to the indirect cycle with a contact condenser. Both of these designs operate with relatively pure steam condensate. However, the compressor engine water chemistries are potentially relevant to indirect systems using surface condensers. The surface condenser concept is not presently used in operating dry cooled power 


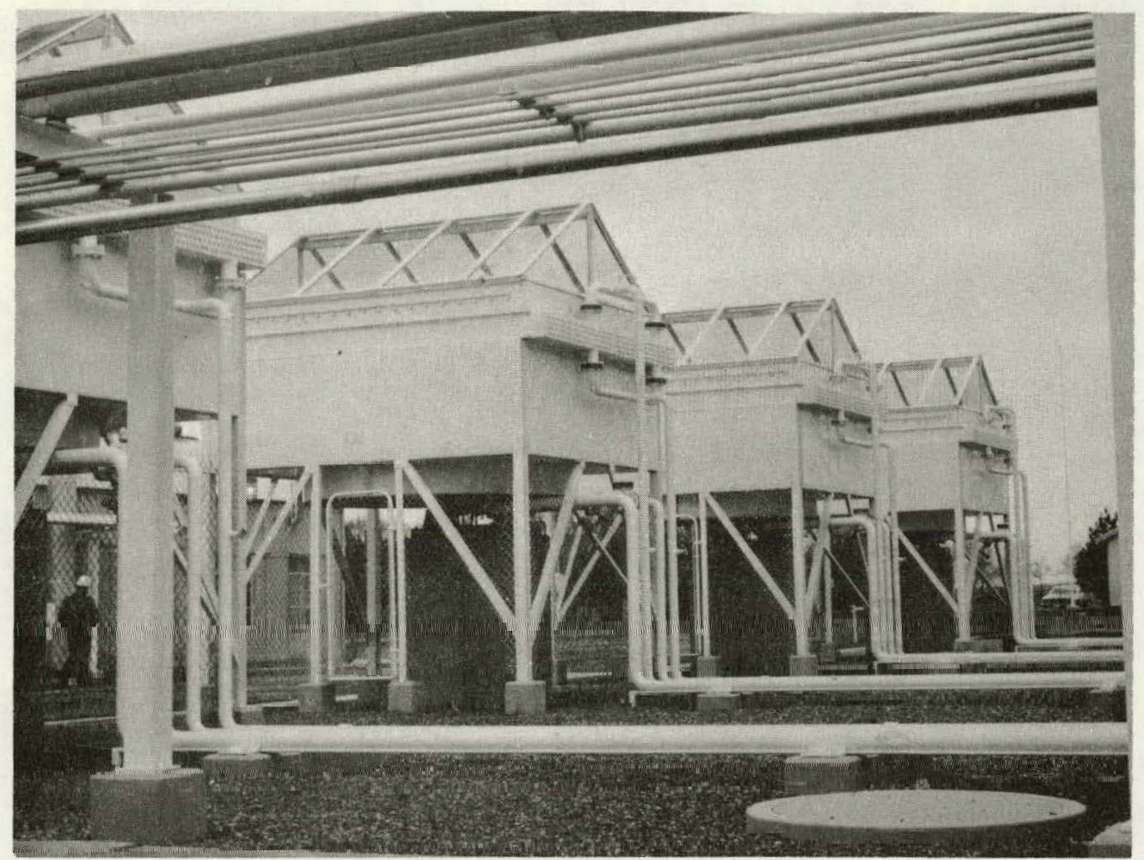

FIGURE 3. Dry Coolers--Unitized Systems--Used to Cool Compressor Engine Jacket Water--Installed 1958

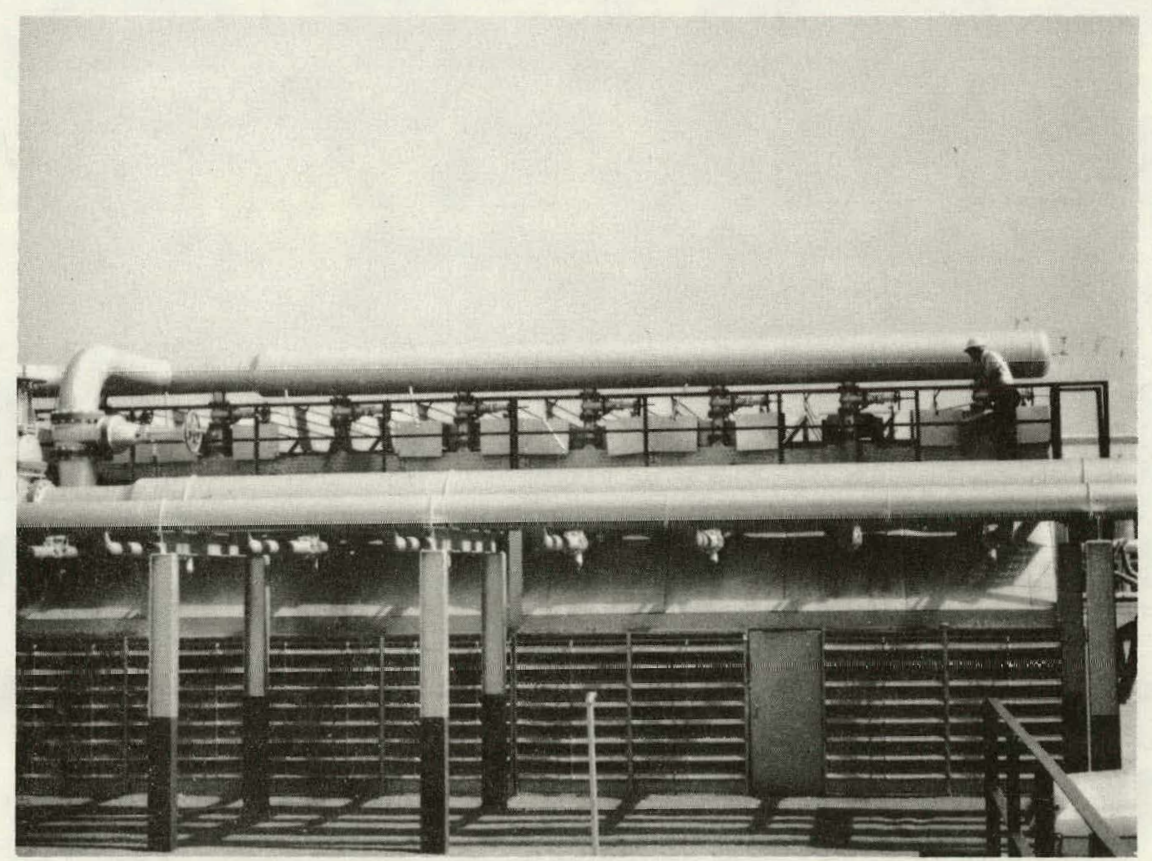

FIGURE 4. Dry Cooler--Common System--Used to Cool Compressor Engine $0 \mathrm{il}$ and Jacket Water; Installed 1952/3 
TABLE 2. Compressor Engine Dry Cooler Summary

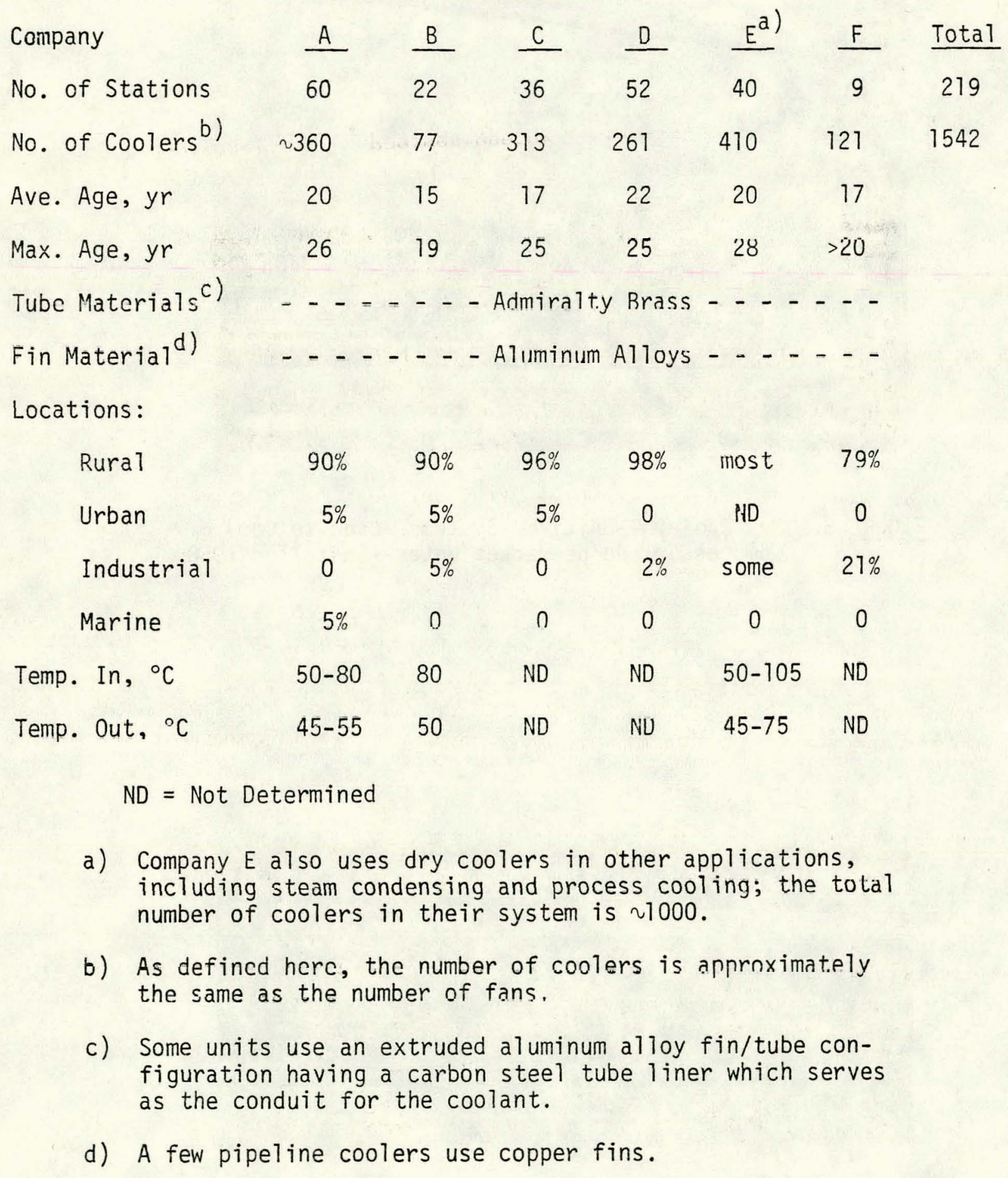


TABLE 3. Comparison of Common and Unitized Coolants

\begin{tabular}{|c|c|c|c|}
\hline \multirow[b]{2}{*}{ Coolant System Volume: } & & Common & Unitized \\
\hline & 1iters & $150,000-750,000$ & $5600-11,000$ \\
\hline & gallons & $40,000-200,000$ & $1500-3000$ \\
\hline Coolant Composition: & & $\begin{array}{l}\text { zero hardness water } \\
\text { (<2.0 ppm total } \\
\text { solids) }\end{array}$ & $\begin{array}{l}\text { - deionized water } \\
(\sim 10 \mu \mathrm{mho} / \mathrm{cm})\end{array}$ \\
\hline & & $\begin{array}{l}\text { ? } 1000 \mathrm{ppm} \text { dichromate } \\
\text { inhibitor }\end{array}$ & $\begin{array}{l}25-50 \% \text { ethylene } \\
\text { glycol }\end{array}$ \\
\hline . & & ${ }^{\circ} \mathrm{pH} 8.4-8.6$ & $\begin{array}{l}1200-1400 \mathrm{ppm} \\
\text { orthophosphate } \\
\text { inhibitor }\end{array}$ \\
\hline
\end{tabular}

stations. However, a surface condenser may be necessary in dry cooled nuclear plants to isolate radiation from the dry cooling tower. Surface condensers are presently being installed in both nuclear (Schmehausen) and fossil (Grootvlei) dry-cooled power plants. The surface condenser will operate with the steam condensate circuit on one side and the closed-loop cooling tower circuit on the other. One estimate $(7)$ indicates that the volume of the cooling tower, circuit would be 25 to 50 times the volume of the condensate circuit. . It will be necessary to control the water chemistry in the closed loop to minimize corrosion of the surface condenser and tower circuits. Deionized or inhibited waters are prospective candidates, which must be weighed against the respective water treatment costs in the relatively large circult. However, elimination of the cooling water corrosion and inleakage problem, characteristic of once through cooling, appears to be a significant advantage of dry cooled plants.

\subsubsection{Corrosion of Compressor Engine Coolers}

Because the compressor engine coolers operate in a temperature regime similar to the air coolers in power stations, the airside corrosion experience is relevant to projections of lifetimes for power station equipment. Dry coolers in compressor engine cooler application have been in service for up to 28 years, which is firm evidence that corrosion has not been a limiting problem in all but two cases. However, quantitative data from 
metallographic examinations) regarding the corrosion of these dry coolers from the date of installation to the present is lacking. Some preliminary metallographic examinations have been conducted as part of this survey and are summarized later in this section.

\subsubsection{Air-Side Corrosion}

Table 2 indicates that more than $90 \%$ of the compressor stations are at rural sites. The range of rural environments includes dry, low humidity locations in the Pacific Northwest and Southwest, where annual rainfalls are ib to $2 b \mathrm{~cm}(6-10$ inches $)$. Uther rurāi sites in the Northwest, South, Southeast and Northeast have annual rainfalls of 90 to $150 \mathrm{~cm} / \mathrm{y}(35-60 \mathrm{in} / \mathrm{y})$.

Because the coolers operate above the dewpoint, they tend to remain dry while on line. In this important respect they differ from materials exposed under normal atmospheric conditions, where time-of-wetness is a major corrosion parameter. The major aspects of atmospheric corrosion will be discussed in more detail in Section 4.2 of this report. "However, moistureladen inlet air which is chemically polluted may be aggressive toward the first rows of tubes. Evidence of this has been seen in units where corrosion rates were relatively rapid. Advanced corrosion caused the solderbonded fins to detach from the bottom tubes; fins on upper tubes were corroded but still attached. Attempts are made to minimize the effect by directing the hot inlet coolant through the tubes which contact the inlet air.

Effects of air-side corrosion on cooler performance are summarized in Table 4 as a function of site location.

The long-term air-side corrosion performance of aluminum fins in pipeline compressor dry coolers has been satisfactory except for a few instances of polluted atmospheres. For example, an aluminum fin specimen was obtained from the bottom row of tubes in a dry cooler that has been in operation in an arid, rural environment for 18 years. Metallographic examination of this specimen indicated only a few shallow pits up to 20.3 $\mathrm{mil}$ in depth; the major portion of the fin surface was essentially undisturbed by corrosion. Of the 219 compressor stations included in this survey, 
serious corrosion of the dry cooler aluminum fins has occurred at only two. One company has experienced corrosion of carbon steel decking and shrouds in humid southeastern environments, but no performance-limiting corrosion occurred on cooler tubes or fins. "Another company has experienced corrosion of copper fins in sour gas ( $\mathrm{H}_{2} \mathrm{~S}$ - and $\mathrm{SO}_{2}$-contaminated) environments; the company has replaced essentially ali copper fins with aluminum.

TABLE 4. Summary of Air-Side Corrosion--

Compressor -Engine "Coolers

Location

Rural-Dry

Rural-Humid

Industria 1-Dry

Industrial-Humid

Marine/Industria]-Humid

\section{Corrosion.}

- no serious corrosion

- no serious fin or tube corrosion

- serious corrosion of steel decking

- no serious corrosion of Al fins and Cu alloy tubes::

- serious corrosion of Cu fins and stee 1 Touvers at sites having $\mathrm{SO}_{2}$ and $\mathrm{H}_{2} \mathrm{~S}$ contaminants

- serious Al fin corrosion at one site located adjacent to a gasoline plant

- serious Al fin corrosion at one site where sulfur and salt water are contaminants

- serious steel component corrosion

The two stations where serious aluminum fin corrosion occurred are both located in the southern U.S. One station is located 20-30 miles from the Guif of Mexico in an agricultural area; a gasoline processing plant is inrated adjarent to the compressor station, but therc is no clear evidence that the gasoline plant contributed to the corrosive attack. Prevailing winds are from the south, off the Gulf. The original coolers at this 
station were constructed in 1949, were of the common design, and used aluminum fins, spiral wrapped on admiralty tubes. The coolers were replaced in 1960 due to corrosion which caused deterioration of the fins. No metallographic examinations of the fins were made, but company personnel stated that the corrosion started at the outer edge of the fin and progressed inward. The fins of the replacement coolers were coated with an epoxy resin to prevent recurrence of the problem.

The other station which has experienced serious fin corrosion is sited in Louisiana in a marine environment. A sulfur mine, processing plant and shipping dock are located about 3.5 miles to the south; the prevailing wind blows northward from the sulfur plant to the compressor station. Oyster shell dust, which is prevalent in the area, is also present in the atmosphere during dry weather. Four coolers of the unitized design were originally installed at this site, two in 1961 and two in 1963. Tubes were admiralty, fins were aluminum, solder-bonded to the tubes. These four units suffered cooling problems starting about three years after installation due to fin deterioration. Fins (solder-bonded) on the lower banks of tubes began to come loose from the tubes, due to corrosion of the fins. However, the corrosion was not at the solder bond. The coolers were replaced in April 1975.

Metallographic examination of fin and tube specimens indicatc that the corrosion attack on the fins was intergranular. Chemical analysis indicates that the fin material is in the 1100 series, probabily 1130.: The attack on the fins on the lower bank of tubes was more severe than the attack on the upper bank.

Analysis of the corrosion mechanism which caused the aluminum fins to fail is not complete. The factors which contributed to the failure appear to be the moist, marine environment and sulfur compound contamination. However; other contaminants have been identified which may have contributed, including lead, fluorine and calcium. At dry, rural sites, soldered fins are performing satisfactorily. Soldered fins are now rarely supplied on new dry coolers. 
Accelerated corrosion of aluminum fins did not occur after 15 years at a site about $100 \mathrm{~km}(60 \mathrm{mi})$ from the site where the accelerated corrosion occurred. Comparing the two sites, sulfur compounds are present at the first site but are not a factor at the second site; salt water is located within two hundred yards of the first site and 1.5 miles from the second site, so the marine influence is minimal at the second site. Both sites have high rainfalls $(65 \mathrm{in} / \mathrm{y}$ or $1.6 \mathrm{~m} / \mathrm{y}$ at the first site; $050 \mathrm{in} / \mathrm{y}$ or 1.25 $\mathrm{m} / \mathrm{y}$ at the second site). Oyster shells are used for ground cover at both sites, suggesting that dusting from the shells is not a significant corrosion factor per se. Some synergistic effect of the oyster shell dust with other corrodents at the first site is possible. A quantitive comparison of corrosion rates at the two sites is being generated from identical corrosion specimens placed at each site. Some specimens are exposed in the hot air above the dry cooled units; some are exposed under ambient conditions.

\subsubsection{Hater-Side Corrosion}

Water-side corrosion was not identified as a performance limiting problem at any of the compressor stations. Inleakage of oil to the coolant caused some fouling on a few compressor engines, but the problem was correctable by flushing out the oil. Mild water-side deposition problems occurred at a few sites, but did not require shutdowns.

A metallographic examination was conducted on an admiralty pipe section from a cooler exposed at the sulfur-contaminated site described under the previuus heading. No evidence of localized corrosion was detectable on the water side after 13 years; the wall thinning rate is estimated to be $20.0005 \mathrm{in} / \mathrm{y}$. A few shallow pits, $\sim$ one to two mils deep were observed on the air side.

In summary, dry jacket water coolers operate in a temperature range pertinent to air-cooled applications in power generating stations. Successful experience up to 28 years is available. Air-side corrosion problems have occurred, but infrequently. In the few cases where severe fin deterioration has occurred, highly contaminated environments were the cause. No performance limiting problems from water-side corrosion have occurred in the jacket water coolers. 


\section{1 .7 Freezing}

Freezing of coolant inside the cooler tubes has occurred at numerous compressor station sites in the past. However, corrective measures have reduced freezing to a minimal problem at most locations.

The only case where recirculation caused plant shutdown occurred at a Gulf Coast site, involving coolers with reduced cooling capacity due to severe fire corrosion. Westerly winds blowing across a compressor engine building carried hot engine exhaust into inlet dir to the coolers. Recent experience with new replacement coolers indicates that with the restored cooling capacity, shutdowns are no longer necessary during periods of severe wind.

At locations where freezing occurs, louvers have been installed to keep water temperatures above freezing by controlling air flows.

At one site, a waste heat boiler used dry coolers to condense steam. Freezing occurred in steam upcomers, causing tube rupture, resulting in removal of the unit from service. This was the only instance encountered in this survey where freezing resulted in removal of equipment from service.

\subsubsection{Recirculation}

Recirculation, or recycling of hot air through the coolers, has not been a major general problem at the pipeline compressor stations, but it can decrease the cooling efficiency of the dry units. One company indicated that they diminished recirculation problems by using induced rather than forced draft fans and by use of stacks 10 feet high above the coolers to channel the hot air away from the cooler inlet air.

One Gulf Coast compressor station had recirculation problems on corroded coolers when westerly winds blowing over a compressor engine building carried hot exhaust into the inlet air to the coolers, forcing shutdown of the engines. Recent replacement of the corroded coolers with new units has solved the problem; the new units operate without shutdown during severe westerly winds. 


\subsubsection{Fouling}

Fouling includes deposits of dust, vegetation and insects which accumulate on the finned tubes. In severe cases, they inhibit air flow and reduce heat transfer. Fouling is controlled through periodic cleaning by hosing with pressurized water; at some sites a mild soap is added to the water; steam cleaning is used as an extreme measure at some sites. Air lances are another less frequent cleaning method. At some locations, annual or semiannual cleaning is . sufficient to suppress fouling. Company $E$ has sprayed the finned surfaces of some dry coolers with tap water to increase cooling efficiency on hot days. The procedure was temporarily effective, but the units gradually lost heat transfer due to scale buildup on the fin surfaces from water impurities.

\subsubsection{Miscellaneous Operational Problems--Gas Compressor Engine Coolers}

Company $A$ indicated that their early installations included a radiator design which was not sufficientiy strong. The tubes developed leaks due to vibration. Company $B$ has had some tube failures on dry coolers due to vibration, caused by fans which were mounted from the cooler frame. The fans are now mounted on concrete pads, which has eliminated the vibration problem.

Company B indicated that care must be used when cooler frames are spray painted. Paint overspray sometimes coats heat exchanger surfaces, resulting in some loss of heat transfer.

Two companies indicated that undersizing of units on initial installation had been a problem. They stressed the importance of correct sizing or slight oversizing to avoid extreme measures on hot days, which may cause other operational problems.

Company $B$ indicated that erosion of fins and other metal equipment has occurred in locations subject to high winds carrying fine sand particles. Replacement of units has been necessary after as little as four years of service because of this problem. No other company surveyed has reported this problem.

Two companies cited gear box failures as an operational problem.

Appendix A summarizes results of a survey regarding compressor engine cooler operational problems. 


\subsection{DRY COOLERS IN THE PROCESS INDUSTRY}

Process industry contacts included a major oil company and a natural gas processing company. Dry coolers with aluminum finned tubes are the predominant means of waste heat disposal in petroleum refineries, natural gas processing plants and chemical plants despite the chemically-poiliuted atmospheres and aggressive in-tube fluids operating at high temperatures and pressures.

\subsubsection{Dry Cooler Performance in Petroleum Refineries}

Table 5 summarizes the types of environments, the numbers of dry coolers involved, and corrosion failure experience from 14 oil refineries in seven countries. Table 6 indicates temperature limitations on the various finned tube designs used by the company. Summarizing the information:

- The predominant fin material is aluminum; the predominant tube material is ASTM A-179 seamless carbon steel; a few units use staiṇless steel and copper alloys, where carbon steel is not suitable; low melting point materials (e.g., brass) are not used with combustible streams; essentially all air cooled heat exchangers use 1 -inch $(2.5 \mathrm{~cm})$ OD tubes.

- The total number of dry coolers is 625; ten operated for 15-20 yr; one operated for $>20 \mathrm{yr}$. (See Table 5 for age distributions.)

- Iwenty-three coolers fatled, w1th ages in the range of one to 12 years; thus, $3.7 \%$ of the coolers failed.

- All failures occurred from the internal side; no failures due to fin corrosion were reported; freezing and loose tube rolls were the failure causes at one site; all other failures were due to tube corrosion by aggressive species.

- The operating temperatures are generally substantially higher than those encountered in dry cooled power stations.

\subsubsection{Dry Cooler Performance in Natural Gas Processing Plants}

Data regarding dry cooler performance in natural gas processing applications appear in Table 7. Some coolers have operated for up to 28 years. The plants are generally in arid, rural locations; plant atmospheres 
TABLE 5. Or.y Cooler Performance in Petroleum Refineries.

\begin{tabular}{|c|c|c|c|c|c|c|c|c|c|c|c|}
\hline \multirow{3}{*}{$\begin{array}{l}\text { Enviromient } \\
\text { Industrial }\end{array}$} & \multicolumn{7}{|c|}{ Approximate Humber of Coolers } & \multirow[b]{2}{*}{$\begin{array}{l}\text { No. of } \\
\text { Coolers } \\
\text { Which } \\
\text { Fotled }\end{array}$} & \multicolumn{3}{|c|}{ Corrosion Problen Experience } \\
\hline & \multirow{3}{*}{$\frac{\begin{array}{c}\text { Tota? } \\
\text { Mumber }\end{array}}{60}$} & \multicolumn{6}{|c|}{ 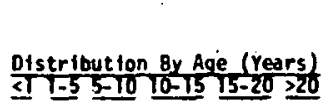 } & & $\begin{array}{c}\begin{array}{c}\text { Age } \\
\text { (Years) } \\
\text { at Fallure }\end{array} \\
\end{array}$ & Service & Mature of Probles, etc. \\
\hline & & $\mathbf{0}$ & 4 & 45 & 11 & 0 & 0 & 1 & 10 & $\begin{array}{l}\text { Lube ofl wax } \\
\text { de-0iler }\end{array}$ & 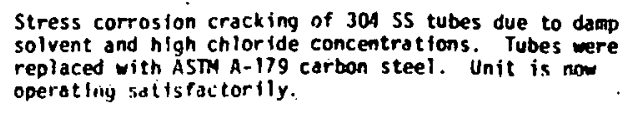 \\
\hline & & & & & & & & 2 & 10 & $\begin{array}{l}\text { Isomax TKC and TKM } \\
\text { sections }\end{array}$ & 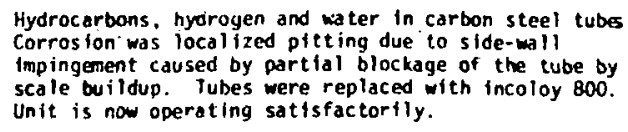 \\
\hline Industrial & 106 & 2 & 36 & 63 & 3 & 2 & 0 & 4 & 5 & $\begin{array}{l}\text { Isomax } \\
\text { CKN section }\end{array}$ & $\begin{array}{l}\text { Internal corroston and erosion of the botion two rows } \\
\text { caused by side and bottom wall impingement from } \\
\text { partial blockage of tube from scale buildup. }\end{array}$ \\
\hline & & & & & & & & 2 & 17 & Cumene Plant & $\begin{array}{l}\text { Localized internal pitting wile units were periodi- } \\
\text { cally out of service. Tubes' were copper-finned car- } \\
\text { bon steel. }\end{array}$ \\
\hline & & & & & & & & 4 & 6 & Delayed Coker & $\begin{array}{l}\text { Internal erosion at the ends of tubes (carbon steel). } \\
\text { cause undetermined. Intend to extend twbe life by } \\
\text { installing ferrules. }\end{array}$ \\
\hline Marine & 18 & 0 & 0 & 0 & 18 & 0 & 0 & 2 & MA & $\begin{array}{l}\text { Crude untt } \\
\text { Overhead condenser }\end{array}$ & $\begin{array}{l}\text { Internal corrosion at the tube inlets caused by mo is- } \\
\text { ture and chlorides. May inject causte el sewhere to } \\
\text { reduce the chloride level in the overhead vapors. }\end{array}$ \\
\hline $\begin{array}{l}\text { Rural and } \\
\text { Industrits! }\end{array}$ & 8 & 0 & 0 & 0 & 8 & 0 & 0 & Mone & & & . \\
\hline Industria] & 13 & 0 & 4 & 1 & 0 & 7 & 1 & 1 & 8 & $120 \mathrm{lbs}$. afr & $\begin{array}{l}\text { Internal pitting due to carbon dioxide in condensed } \\
\text { water. }\end{array}$ \\
\hline Industrial & 61 & 14 & $20^{\circ}$ & 13 & 14 & 0 & 0 & 2 & $6-8$ & Hydrocracker & $\begin{array}{l}\text { Internal corroston/erosion caused by wet sulfide and } \\
\text { wet. chloride. (0ther than corrosion, these problens } \\
\text { have been encountered: Tube distortion due to high } \\
\text { row temperature difference, plug leaks, fan blade } \\
\text { vibration fatigue.) }\end{array}$ \\
\hline Industrial & 4 & 0 & o & 3 & 0 & $\mathbf{I}$ & 0 & Mone & & & \\
\hline Industrial & 12 & 0 & 12 & 0 & 0 & 0 & o & Mone & & & $\begin{array}{l}\text { Only probiems have been frozen and split tubes and } \\
\text { loose tube rolls. }\end{array}$ \\
\hline industrfal & 125 & 55 & 10 & 60 & 0 & 0 & 0 & 2 & 4 & $\begin{array}{l}\text { Crude units } \\
\text { Overhead condensers }\end{array}$ & $\begin{array}{l}\text { Corrosion/erosion or inlet end of tubes, caused by } \\
\text { high velocity and improper chemical treatment injec- } \\
\text { tion systen. }\end{array}$ \\
\hline Industrial & 12 & 0 & 1 & 3 & 8 & 0 & 0 & None & & & \\
\hline $\begin{array}{l}\text { kursi } \\
\text { (oli fteld) }\end{array}$ & 4 & 0 & 0 & 0 & 4 & 0 & 0 & 1 & 12 & $\begin{array}{l}\text { O1l dehydration } \\
\text { condensers }\end{array}$ & $\begin{array}{l}\text { Internal corrosion in the first eight feet of tube, } \\
\text { where naphtho vapor and stean is condensed. Cor-, } \\
\text { rosion is caused by sulfur content of the crude ofl. } \\
\text { it can be contralled by an inhibitor. }\end{array}$ \\
\hline Industrial & 48 & 0 & 11 & 37 & 0 & 0 & 0 & Mone & & & \\
\hline Industrial & 90 & 0 & 0 & 27 & 67 & 0 & 0 & 1 & Mia & $\begin{array}{l}\text { Crude units } \\
\text { Overhead condensers }\end{array}$ & $\begin{array}{l}\text { Internal corrosion at inlet area, typical acldic cor- } \\
\text { rosion. Tubes were replaced with new tubes with a } \\
\text { spectai internal coating. }\end{array}$ \\
\hline Rural & 60 & 0 & 60 & 0 & 0 & 0 & 0 & 1 & 3 & & $\begin{array}{l}\text { Internal corrisition of ofly-mater effluent cooler. } \\
\text { caused by solits present in the ofly-water. }\end{array}$ \\
\hline
\end{tabular}

$\begin{array}{lllllllll}\text { TOTAL Coolers } & 625 & 71 & 158 & 261 & 127 & 10 & 1 & 23\end{array}$

MA - Mot avallable 
TABLE 6. Temperature Limits for Various Finned Tube Designs*

Temperature Limit

Finned Tube Design

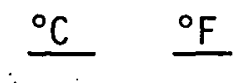

- Fins wrapped under tension and mechanically embedded

$400 \quad 750$

in a groove spirally cut into the outer surface of

the tube

- Inner tube (or liner) mechanically bonded to an alumi- 288550 num outer tube from which fins have been formed by extrusion

- Aluminum footed fins wrapped under tension over the outside surface of a grooved tube and pressed into the groove

- Aluminum footed fins wrapped under tension over the outside surface of the tube

*These are guidelines used by one petroleum refiner and do not necessarily represent limits generally accepted in the industry.

frequently contain substantial concentrations of $\mathrm{SO}_{2}$ and $\mathrm{H}_{2} \mathrm{~S}$. Specific failure rate information was not available for all sites. The principal air-side corrosion problem has occurred on copper-finned tubes exposed to the sulfide and sulfur oxide contaminated atmospheres. Most copper-finned tubes have been replaced with aluminum-finned tubes. The aluminum tubes appear to perform adequately.

In summary, in the rural, arid, environments contaminated with $\mathrm{SO}_{2}$ and $\mathrm{H}_{2} \mathrm{~S}$, aluminum and galvanized fins appear to operate satisfactonrily; the hot steel tubes also appear to survive, but steel louvers undergo rusting. At similar dry locations where sulfur is absent, steel corrosion is not a problem. (Compare Figures 5 and 6.) Internal corrosion has been a substantial cause of tube replacement, but specific details regarding the failure frequency are not available. Admiralty tubes appeared to give 
TABLE 7. Dry Cooler Performance in One Company's Gas Processing Operations

\begin{tabular}{|c|c|c|c|c|c|c|}
\hline \multirow[b]{2}{*}{ Operation } & \multirow{2}{*}{$\begin{array}{l}\text { Number of } \\
\text { Sections (a) }\end{array}$} & \multicolumn{2}{|l|}{ Materials } & \multicolumn{2}{|c|}{$\begin{array}{c}\text { Operating } \\
\text { Temperatures, }{ }^{\circ} \mathrm{F} \\
\end{array}$} & \multirow[b]{2}{*}{ Remarks } \\
\hline & & Fins/Tubes & Headers & Inlet & Outlet & \\
\hline Gas Coolers & $\begin{array}{r}>130 \\
>51 \\
3 \\
2 \\
18 \\
>204\end{array}$ & $\begin{array}{l}\text { Aluminum/Admiralty } \\
\text { Aluminum/Steel } \\
\text { Aluminum/70-30 Cu-Ni } \\
\text { Steel/90-10 Cu-Ni } \\
\text { Unknown }\end{array}$ & $\begin{array}{l}\text { Steel or } \\
\text { cast iron }\end{array}$ & $120-600$ & $113-199$ & $\begin{array}{l}\text { 0ldest operating } \\
\text { unit installed } \\
\text { in } 1952\end{array}$ \\
\hline Steam Condensers & $\begin{array}{r}>36 \\
26 \\
\quad 9 \\
>71\end{array}$ & $\begin{array}{l}\text { Aluminym/Admiralty } \\
\text { Copper }(b) / A d m i r a 1 t y \\
\text { Aluminum/90-10 Cu-Ni }\end{array}$ & $\begin{array}{l}\text { Steel or } \\
\text { cast iron }\end{array}$ & $154-389$ & $120-200$ & \\
\hline $\begin{array}{l}\text { Still Reflux } \\
\text { Condensers }\end{array}$ & $\begin{array}{r}45 \\
22 \\
24 \\
7 \\
98\end{array}$ & $\begin{array}{l}\text { Aluminum/Admiralty } \\
\text { Aluminum/Steel } \\
\text { Aluminum/Aluminum } \\
\text { Aluminum/Tinned Steel }\end{array}$ & $\begin{array}{l}\text { Steel or } \\
\text { cast iron }\end{array}$ & $171-250$ & $120-210$ & $\begin{array}{l}\text { 0ldest operating } \\
\text { unit installed } \\
\text { in } 1954\end{array}$ \\
\hline $\begin{array}{l}\text { Still Overhead } \\
\text { Condensers }\end{array}$ & $\begin{array}{r}14 \\
>14 \\
3 \\
2 \\
2 \\
>35\end{array}$ & $\begin{array}{l}\text { Aluminum/Steel } \\
\text { Aluminum/Tinned Steel } \\
\text { Aluminum/Aluminum } \\
\text { Aluminum/Admiralty } \\
\text { Copper(b)/Admiralty }\end{array}$ & $\begin{array}{l}\text { Steel or } \\
\text { cast iron }\end{array}$ & $142-225$ & $120-165$ & \\
\hline Soluticn Coolers & $\begin{array}{r}>28 \\
5 \\
>33 \\
\end{array}$ & $\begin{array}{l}\text { Al uminum/Steel } \\
\text { Aluminum/Admiralty }\end{array}$ & $\begin{array}{l}\text { Steel or } \\
\text { cast iron }\end{array}$ & $174-338$ & $120-200$ & \\
\hline TOTAL & $>441$ & & & & & \\
\hline
\end{tabular}

a. A section includes a single bank of tubes; the number of sections is approximately equal to the number of fans.

b. Appear to have been replaced with aluminum.

NOTE: > indicates that actual number is mildly higher than the number indicated. 


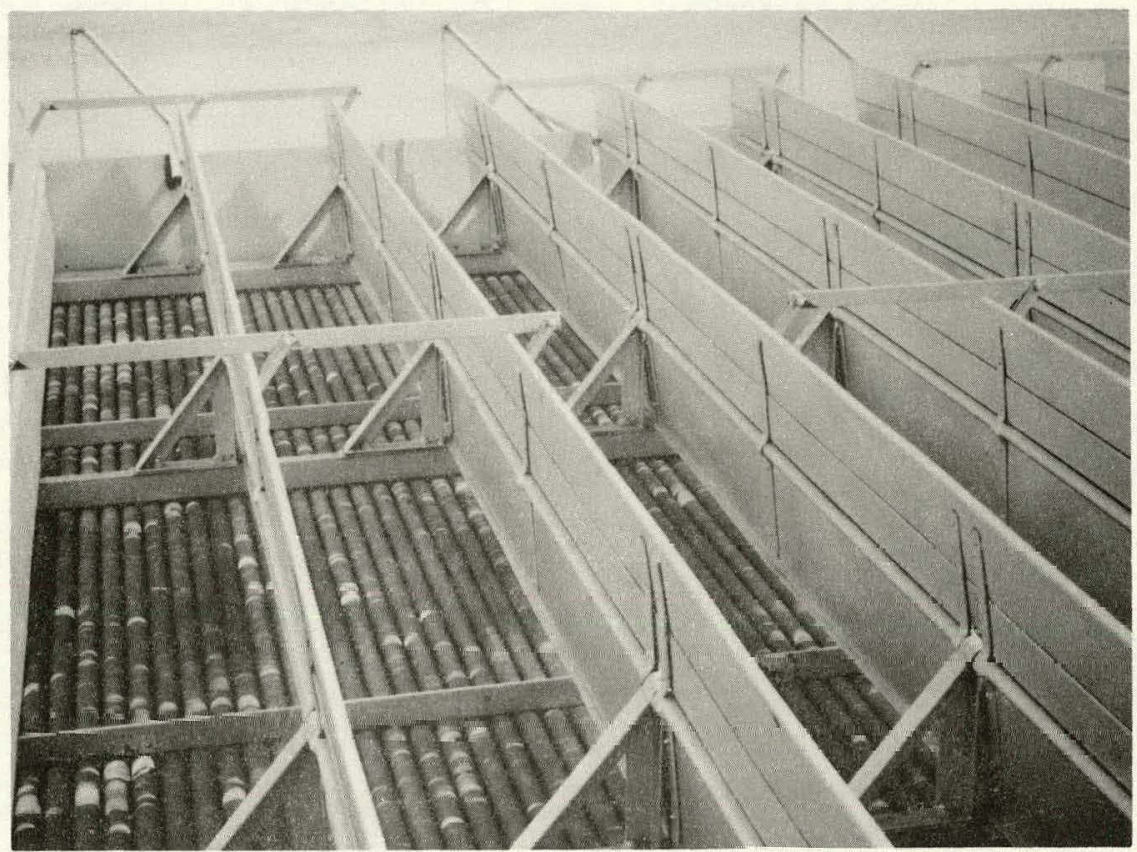

FIGURE 5. Dry Cooler in Sulfur-Free Environment (Company E)

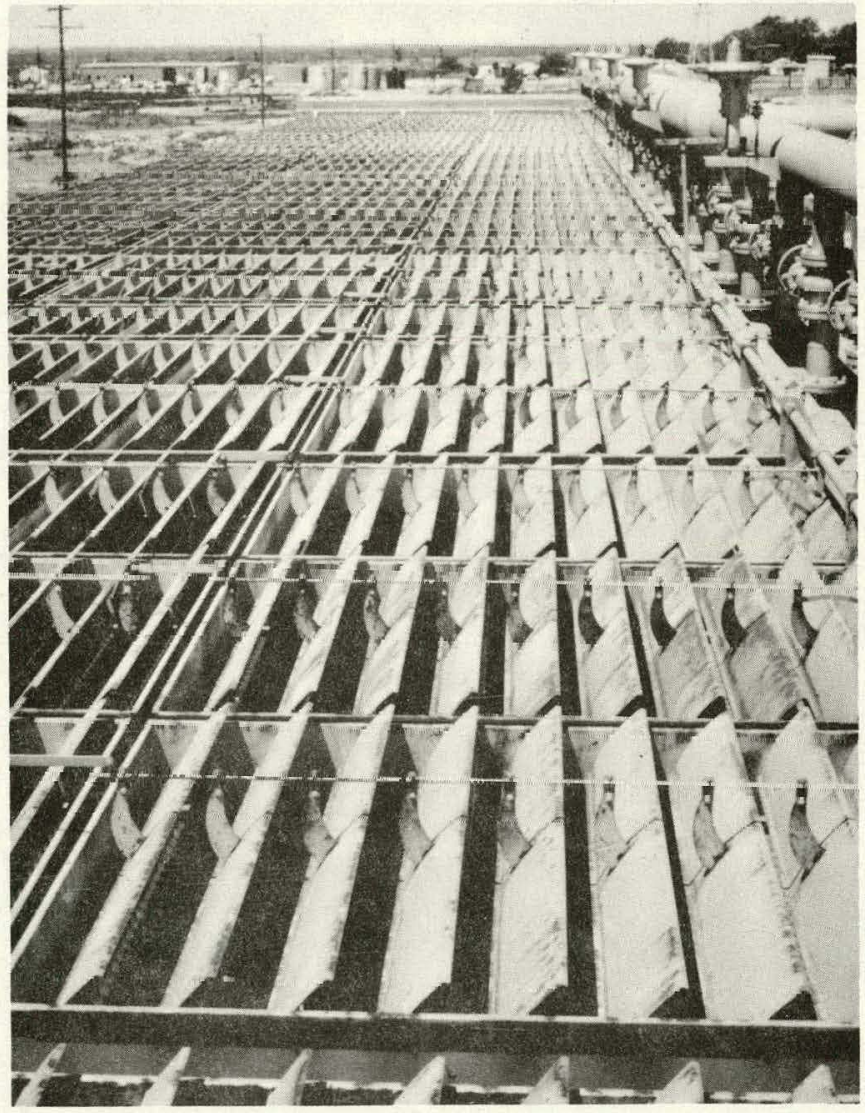

FIGURE 6. Dry Cooler in Sulfur-Contaminated Environment (Company E) 
satisfactory service in jacket water and steam condensing applications. Finned tube designs which.avoid crevices have the advantage that they provide more corrosion protection of the base tube metal and an enhanced heat transfer integrity compared to embedded, pressed and footed aluminum fins of the type described in Table 6. Corrosion may loosen the heat transfer bond between the tube and the aluminum fin that is embedded, pressed or footed, and thereby increase its thermal resistance and reduce its overall heat transfer capability.

Other equipment problems on the gas refinery dry coolers are summarized below:

- Gear box failures occurred at one plant; the failures occurred on small (16. hp) units, of the right-angle gear design; the failures occurred from chipping, breaking and wearing of gear teeth; the gear box horsepower rating was adequate for the fan ratings, but failures were due to shock loads during fan reversal when units were stopped or started; replacement with larger units is expected to solve the problem.

- Freezing has occurred in coils on steam condensers; the solution has been to install louvers either over the coils (Figs. 5 and 6), on the sides of the air-cooled units (Fig. 4). or both; in some units, variable pitch, automatically controlled fans are used; the key to prevent freezing is to have flexibility on air flows, reducing the flows as the temperatures approach freezing conditions; good temperature control has been attained with one variable pitch fan on automatic control in conjunction with one or more fixed pitch fans on automatic on-off temperature control. Louvers also are sometimes installed with automatic temperature controls.

- Hail damage was obvious at some locations, characterized by substantial numbers of grossly bent fins (Fig. 5); hail screens and/or louvers are used over some units to protect the fins.

- Some stainless steel fan.blades failed by. s.tress corrosion cracking; plastic and aluminum. blades have performed satisfactorily. Most of the dry coolers in this company's plants have fans driven by 
electric motors; a few locations have hydraulic drives, which involve oil-driven fan motors; the hydraulic drives provide variable fan speeds to control temperatures; they are most prevalent at remote locations where electric power is not available.

\subsection{MATERIALS PERFORMANCE IN WET/DRY COOLERS}

The wet/dry cooling concept combines conventional evaporative cooling with finned-tube heat exchangers. Several alternative designs are possible, depending on the sequencing of air and water flows through the wet and dry sections. The air can flow through the two sections either in series or in parallel. Likewise, the water flows can be series or parallel.

Principal justifications for the wet/dry concept for power plants include plume abatement and water conservation, when compared with the wet tower concept. The deluge concept provides an additional option, which involves flooding the cooler surfaces with water to enhance heat transfer. The various wet/dry concepts are treated in detail elsewhere. $(10,11)$ Experience with intentional wetting of extended surfaces in the United States has not been totally successful. Water solids and airborne particulates cause fin-side fouling problems which affect not only heat transfer conductance but also mass air flow. (11)

\subsubsection{Wet/Dry Cooling Towers}

Wet/dry coolers have been marketed since the late 1940's. Vendors which supply finned tube wet/dry coolers include Ecodyne, Hudson Products, and Marley. Typical materials in wet and dry sections appear in Table 8. The only fin material which has seen over 15 years service in wet/dry towers in the United States process industry is extruded aluminum. Galvanized steel has had mixed performance in the humid section of wet cooling towers and in wet/dry towers; corrosion of galvanized steel is dependent on water chemistry.

In most wet/dry configurations installed at power plants, the finned tubes in the dry section are vertical, compared to the normal horizontal attitude in all-dry coolers. Wet/dry towers used at process plants have the same horizontal tube configuration as the all-dry coolers. 
TABLE 8: Materials in Conventional Wet/Dry Coolers

\begin{tabular}{|c|c|}
\hline Wet Section & Dry Section \\
\hline $\begin{array}{c}\text { Structure: galvanized steel } \\
\text { wood }\end{array}$ & $\begin{array}{l}\text { al uminum* } \\
\text { steel }\end{array}$ \\
\hline 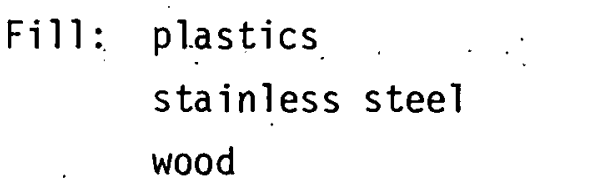 & $\begin{array}{l}\text { stainless steel } \\
\text { copper alloys } \\
\text { Tubes: steel }\end{array}$ \\
\hline Dampers: a luminum & $\begin{array}{l}\text { stainless steel } \\
\text { copper nickel } \\
\text { admiralty }\end{array}$ \\
\hline
\end{tabular}

*Coated fins can be specified

Water chemistry control in wet/dry units involves $\mathrm{pH}$ control, usually, by $\mathrm{H}_{2} \mathrm{SO}_{4}$ additions, and chlorine additions to suppress algae and bacteria.

The range of potential operational problems in wet/dry systems covers the range characteristic of the separate systems, such as corrosion, freezing, fan/motor failure, etc. In addition, there is a higher tendency for corrosion on dry sections coupled to wet coolers than on dry sections operating alone for the following reasons:

- The moisture content of the air passing over the dry section is increased by proximity to the wet section. The chemically-laden drift and moist vapors discharged by the tower fans are recirculated under certain conditions back to the dry tower section.

- The vertical configuration of the finned tubes places the fin surfaces in the horizontal position, tending to promote moisture accumulation on the fins during operation and downtime; the effect is enhariced if the design includes crevices where moisture can accumulate.

- Purity control of the circulating water is more difficult than in the closed cycle dry systems; water which circulates through the tubes in the dry section absorbs oxygen and other impurities from the atmosphere while passing through the wet section. 
Specific instances of severe corrosion in wet/dry units include rusting of carbon steel. tubes due to exposure to the oxygenated coolant on the interior and to moist air on the exterior tube surfaces. Advanced rusting occurred within the first year of service. Another case involved crevice corrosion on a spiral-wrapped aluminum fin on an admiralty tube after five years of service. White corrosion product developed on aluminum surfaces in contact with the admiralty tube. The probable mechanism is moisture accumulation in the crevice supporting the electrochemical corrosion of the aluminum as a result of galvanic effects iii cunlact with copper, possibly combined with oxygen concentration cell action,

\subsubsection{Deluge Systems}

In deluge systems, water passes over the exterior cooling surfaces. If deposition of impurities from the water is minimal, heat transfer is enhanced.

The Niagara Blower Co. markets a system involving concurrent flow of a water spray and air (induced draft) over the outer surfaces of tube bundles made from unfinned tubes. Tube bundles, straight-through or serpentine type, are mounted horizontally. Construction materials include hot-dip galvanized steel, stainiess steel and ronper alloys.

The system involves oxygenated water of relatively low purity, compared to steam condensate. In some waters $\mathrm{pH}$ cont.rol is used to suppress scaling. Blowdown ( $<5 \%$ of the water. inventory) also is practiced, to control scaling. The manufacturer indicates that scale on tube exterior surfaces will not develop with proper water treatment ( $<300 \mathrm{ppm}$ total solids) and if exterior surfáce temperatures are maintained below $150^{\circ} \mathrm{F} .(12)$ surface coatings, generaliy rubberized materials, are used to minimize corrosion of the water reservoir.

Four companies were contacted regarding the performance of the Niagara Blowers: A steel plant, an automobile manufacturer, a metal fabricator and a metal caster. Observations are summarized below:

- The oldest unit had been on line since 1956. It showed some corrosion of sheet metal panels, light corrosion of aluminum louvers 
and mild rust on exhaust screens. The tube bundle material was a copper alloy. Some sćale was evident on the tube surfaces, but the unit had operated without major problems.

- A unit installed in 1967 was galvanized at the mill prior to assembly. 0lder and later units were galvanized after assembly, which appears to provide better corrosion resistance. A unit installed at the same plant in 1972 had some scale deposit on the copper tubes, but no visible corrosion.

- One company has five Niagara blowers which have been on 1 ine 15 years. Each unit disperses $50 \times 10^{6}$ Btu/hr. Scale up to $\sim 1 \mathrm{~mm}$ ( 0.04 in.) thick was collected from the tube bundle in one unit. The plant is installing equipment for automatic $\mathrm{pH}$ monitoring and control to inhibit scale formation. Considerable corrosion was evident on sheet metal panels. The tube bundles were 12 pipes high and 21 pipes wide. The pipes were $1.9 \mathrm{~cm}(0.75 \mathrm{in.})$ ID.

- One company had replaced the blowers with dry cooled equipment after ten years. The reasons cited were that the units had serpentine coils, which were difficult to clean mechanically. Deposits formed, due to poor water quality.

- One plant operator has a unit which cools an extrusion press and dissipates 1,750,000 Btu/hr; the tubes are copper; the cooling water temperature is $105^{\circ} \mathrm{F}$ max; the process side temperature is maintained at $120^{\circ} \mathrm{F}$; the unit has operated since 1959 without serious corrosion problems; minimal air-side corrosion has occurred; steel panels are cleaned annually and are repainted every three years; the water $\mathrm{pH}$ is maintained at 8.5 to 9.0 to minimize corrosion of steel components such as valves; the experience with the unit has been better than design expectations; wind effects have not caused operational problems; freezing caused plant shutdown twice one year and once the following year; louvers were installed in the cold air intake to solve the freezing problem; all plant maintenance is performed during schedule shutdowns; the principal problems with the unit have been corrosion and leakage of valves and fittings. 
A wet/dry concept for deluge cooling of plate-type fins is under investigation at Ivanavo, Russia, based on Hungarian experiments. The field demonstration plant will be 60 MWe. The concept involves construction of a cooling assembly from plate-type fins arranged in an inverted $V$ configuration. Hot water passes through horizontal tubes cooled by the fins. The leading candidate for fins and tubes currently is aluminum. During periods of relatively high temperature, air cooling of the fins would be supplemented by injecting cold water at the apex of the $V$; water would flow downward over the exterior surfaces of the fins and be cycled to a reservoir before returning to the cooling tower. During warm weather, the tower would operate in the deluge mode a large fraction of each day, returning to the dry mode at night.

In simulation tests, the $\mathrm{pH}$ of the deluge water was maintained below 7.5. Dissolved solids concentrations were 400-500 ppm. Carbonate was : $35 \mathrm{mg}$ /equiv. Makeup water was acidified; chloride levels were very low. Algae is not considered by the Russians to be a problem because of the periodic drying.

Studies are planned for the period 1976-79 to investigate water consumption, water chemistry control requirements, deposition, corrosion and methods of water distribution to the finned surfaces.

\subsection{INDUSTRIAL STEAM CONDENSERS}

Dry coolers are used by Company E (Table 2) for. condensing steam in industrial steam generating stations; steam condensation rates are 11,340 $\mathrm{kg} / \mathrm{hr}(25,000 \mathrm{lb} / \mathrm{hr})$. In a typical plant (Figure 7) the inlet steam temperature is $104^{\circ} \mathrm{C}\left(219^{\circ} \mathrm{F}\right)$; the exiting condensate temperature is $52^{\circ} \mathrm{C}\left(125^{\circ} \mathrm{F}\right)$. The tubes are admiralty, $12.2 \mathrm{~m}(40 \mathrm{ft})$ in length and $2.5 \mathrm{~cm}(1 \mathrm{in})$ diameter. The fins are aluminum. The water chemistry is summarized below:

$$
\begin{aligned}
& \text { Steam condensate } \mathrm{pH} \\
& \text { condensate } \mathrm{Cl}^{-} \\
& \text {alkalinity }
\end{aligned}
$$

$$
7.5-8.0
$$$$
20 \mathrm{ppm}
$$$$
4 \mathrm{ppm} \text { (mcthyi orangc) }
$$ 


$$
\begin{aligned}
& \text { Boiler water } \mathrm{pH} \\
& \text { Sulfite is added for oxygen control. } \\
& \text { Phosphate is added for hardness control. } \\
& \text { Feedwater is softened by a zeolite process. }
\end{aligned}
$$

The plant shown in Figure 7 has operated approximately two years without corrosion or other operational problems.

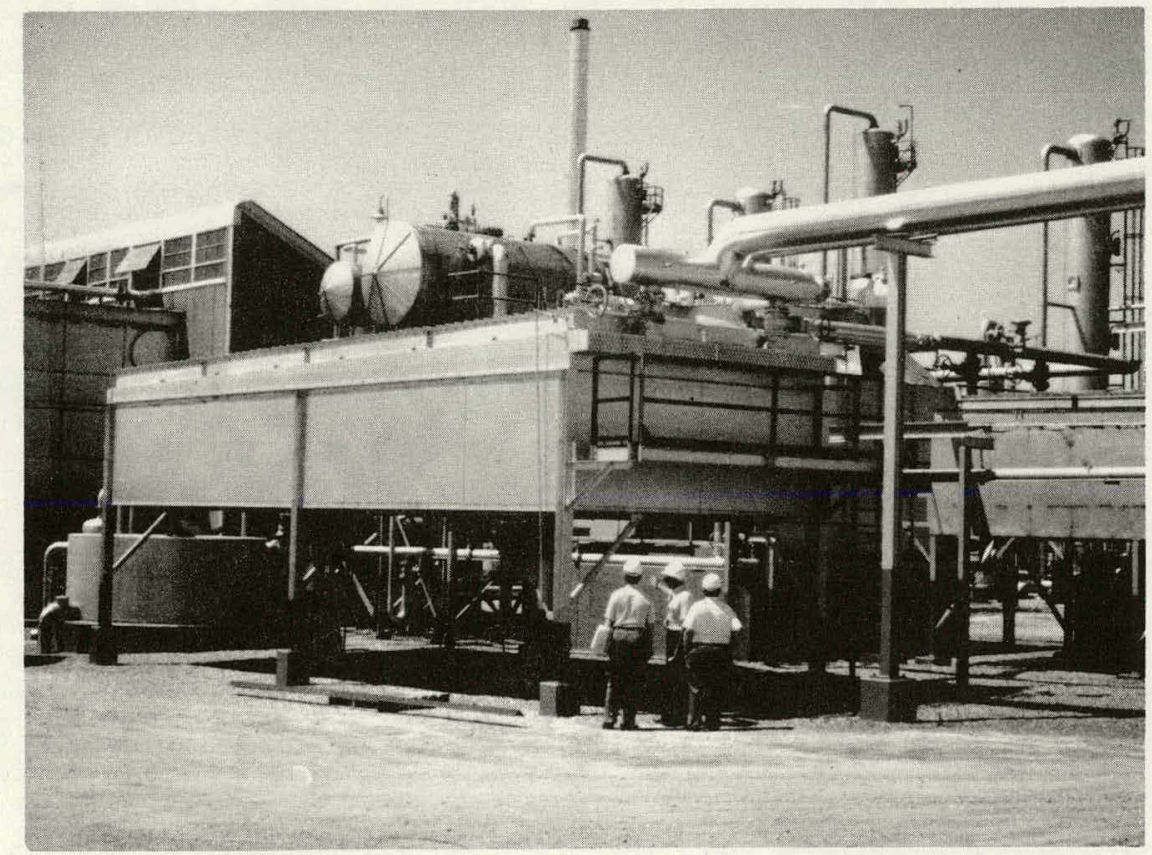

FIGURE 7. Air-Cooled Steam Condenser (Company E)

\subsection{DISCUSSIONS WITH DRY-COOLED EQUIPMENT VENDORS}

The three dry-cooled equipment vendors shown below were contacted regarding design and performance of their products:

Hudson Products, Houston, Texas

Marley Company, Mission, Kansas

Ecodyne, Santa Rosa, California and Massillon, Ohio (MRM Division) 
These represent the largest U.S. vendors of dry-cooled equipment, but they are not the only suppliers.

\subsubsection{Discussions at Hudson Products, Inc.}

Hudson indicated that less than three percent of their units have been replaced due to corrosion. However, the failures occurred predominantly from the process side in the dry cooled units, due to corrosive process solutions. A major source of failure is ammonia attack on carbon steel pipes. In applications where the coolant chemistry can be carefully controlled, such as the pipeline coolers cited earlier, the failure rates are a fraction of one percent. The most common problems on the air side have occurred on wet/dry units, where corrosion rates are higher than on dry units. Some dry-cooled units have been replaced due to scale buildup caused when they were sprayed repeatedly with low purity water to increase cooling during periods of high ambient temperature. The Hudson staff indicated that up to 80 percent of the air-side corrosion occurs on the bottom row of cooler tubes, which must be taken into account in corrosion sampling.

The most common a11oys used at Hudson are A-214 carbon steel for tubes and 1100 and 6063-F aluminum for fins. Up to 1945-47 nearly all dry cooler fins were fabricated from copper alloys, due to lower cost. The fins were either wrapped on or soldered. In sulfur-contaminated atmospheres, the copper fins deteriorated rapidly due to corrosion, initiating both at the fin tips and at points of attachment to the tubes. Extensive use of aluminum fin materials began about 1947. Aluminum generally is tolerant of atmospheres contaminated with $\mathrm{H}_{2} \mathrm{~S}$, unless water is present. Admiralty tubes and aluminum fins have been a preferred combination for jacket water coolers. However, cost advantages are causing a trend toward use of carbon stee 1 tubes as liners for extruded aluminum fins.

The Hudson staff made the following points regarding coatings:

- Organic cuatings are expensive; in 1975 polyurethancs cost about $\$ 0.70$ per linear foot of finned tube; epoxy coatings cost about twice as much; coatings can essentially double the cost of the finned tube; 
- The coating imposes a penalty on heat transfer;

- It is questionable that organic coatings will last for the life of the equipment; however, Hudson supplies coated equipment if specified by the customer;

- Galvanized coatings have performed well in most applications; there have been some cases of poor-quality coatings, principally from inadequate thickness control; costs of organic coatings and galvanizing were indicated as being similar, but the trend is to galvanizing because of potentially greater long term benefits in most environments.

Corrosion in wet/dry systems is minimized by drift eliminators, which limit moisture carryover from the wet system to the finned tubes in the dry sections. However, the eliminators are never $100 \%$ effective, resulting in moisture carryover which promotes corrosion and scale buildup on the finned tubes.

The Hudson staff was optimistic that air-cooled equipment will function satisfactorily in central power station applications. Nuclear plants are particularly attractive, due to the lack of atmospheric contaminants.

\subsubsection{Discussions at Marley}

The Marley Company has conducted accelerated corrosion tests involving air-side and water-side investigations. The results have been reported(14) and will be only briefly summarized here.

In a joint program initiated at the request of American Electric Power Service Corporation, Marley exposed sections of aluminum finned tubes at five sites, including rural, industrial and marine environments. Ethylene glycol solutions were sealed inside the tubes to provide an acceleration factor; due to thermal inertia which maximized early morning moisture condensation on the external surfaces. Some specimens had electrodeposited acrylic coatings on the external surfaces; coating thicknesses were about 25 to $35 \mu \mathrm{m}(0.001$ to $0.0015 \mathrm{in})$. The aluminum fin alloys were 1100, 7072, and 3003; tube materials were 3003, 6061 and 5052 aluminum alloys, steel and admiralty. 
The corrosion specimens were exposed unheated, therefore simulating shutdown conditions. The test results after 44 months indicated the following:

- corrosion varied markedly from site to site; the marine and industrial sites rapidly degraded the uncoated fins and showed little difference among the.alloys; attack at rural sites was mild;

- attack on the fins involved severe localized pitting;

- exterior tube corrosion was less severe than fin corrosion, suggesting possible fabrication effects, since one of the alloys (3003) was represented in fins and tubes;

- the electrodeposited acrylic coatings suppressed corrosion.

The tests reinforce other atmospheric corrosion data indicating large differences in corrosion rates from site to site because of chemicallypolluted atmospheres. The Marley staff indicated the view that the corrosion of candidate materials needs to be evaluated at the specific sites where they will be used. The test indicated that coatings were beneficial over the test duration (up to 44 months). However, much longer exposures are needed to assure that the coatings would not eventually degrade in the aggressive environments over the 1 ife of a plant ( $30 \mathrm{y})$.

The atmospheric corrosion tests demonstrated that certain chemicalilypolluted environments will degrade aluminum cooling tower materials under shutdown conditions. They underscore the need to develop corrosion data for various types of atmospheric pollutants.

The method of fin attachment was indicated to be an important determinant in fin corrosion. Crovicer, tend to promote corrosion in moist environments. Early sampling inspections indicated slightly more corrosion or horizontal fins, but all subsequent inspections showed no measurable differences between vertical and horizontal fins.

In addition, corrosion of the fins roughened their surfaces and accentuated entrapment of fouling materials. In some cases, this secondary 
effect can be more important than the actual corrosion damage itself with regard to the equipment performance.

The Marley staff recognized that there are uncertainties regarding the long-term performance of coatings. They estimated that break-even cost would occur if the coating extended heat exchanger life by 15 percent.

Marley conducted tests of water-side corrosion of candidate tube materials with American Electric Power Company. The tests included aluminum alloys, copper and admiralty. Tube internal surfaces were exposed to flowing $(\sim 1.5 \mathrm{~m} / \mathrm{sec})$ steam condensate at $60^{\circ} \mathrm{C}\left(140^{\circ} \mathrm{F}\right)$. The $\mathrm{pH}$ range was 9 to 10, with hydrazine being the principal factor in the relatively high $\mathrm{pH}$. Aluminum corrosion rates were high, with penetrations up to $\sim 100 \mu \mathrm{m}(0.004 \mathrm{in})$ in six months. Corrosion rates on copper and admiralty were almost nil. Two factors may have contributed to the high aluminum corrosion: a) the relatively high $\mathrm{pH}$, controlled by hydrazine; (5) b) the possibility of copper contamination from a heat exchanger in the system; it is recognized that even low levels of dissolved copper cause accelerated corrosion of aluminum in aqueous systems. (15) However, this is less likely to occur in closed recirculating systems. In open systems, water treatments are commercially available which will properly control this condition.

\subsubsection{Discussions at Ecodyne and MRM}

Ecodyne at Santa Rosa manufactures wet and wet/dry systems. MRM (McKenzie-Ris Manufacturing Corporation) is the dry-cooled equipment division of Ecodyne, located at Massilion, Uhio. In 1960 MRM took over operation of Griscom-Russe1i, which began manufacturing dry-cooled equipment in the 1930 's.

Plume abatement presently is the major justification for wet/dry systems, but in 5 to 10 years water conservalion will become a strong incentive. Comments regarding wet/dry system materials and corrosion performance were presented in the section on wet/dry systems.

To avoid freezing in wet/dry units, Ecodyne uses the following measures: 
- closure of air dampers on the upwind side

- wind walls

- vertical walls to minimize splash on louvers

- fan reversal as required to deice louvers.

The MRM dry-cooled units are supplied with aluminum (principally alloy 1100), copper, steel or stainless steel fins. Principal tube materials are steel, stainless steel, and copper base alloys, but other tubes can be supplied. The principal fin designs are: wrap-on type shoulder tension fins which are satisfactory for service up to $200^{\circ} \mathrm{C}\left(400^{\circ} \mathrm{F}\right)$; shouldergrooved fins, which are embedded in and protect the tube in service to $350^{\circ} \mathrm{C}\left(650^{\circ} \mathrm{F}\right)$; and edge-grooved fins, good for service exceeding $500^{\circ} \mathrm{C}$ in certain metal combinations.

Air-side fouling has generally been a minor problem in the air-cooled units, compared to scale, corrosion and biological fouling in water-cooled units. Annual cleaning of fin surfaces is adequate at most locations. 


\section{CORROSION BEHAVIOR IN DRY-COOLED POWER GENERATING STATIONS}

The foregoing survey has concentrated on U.S. industrial air-cooled units. Most are relatively small. Many have airside corrosion conditions which are relevant to drycooled power stations, but water chemistries generally differ from current power station cooling tower chemistries, which involve steam condensate. It is essential to a rounded view of dry cooling tower corrosion and water chemistry technology that information from operating dry-cooled power plants be presented. The following information is derived from the literature and from plant visits ${ }^{(16)}$. Information from direct cycle and indirect cycle plants is included.

\subsection{DIRECT CYCLE PLANTS}

Direct cycle central power stations included in this survey are the Volkswagenwerk at Wolfsburg, Germany, the Neil Simpson Station at Wyodak, Wyoming and the Union Termica Station at Utrillas, Spain. Table 9 below provides data regarding the plants. Other direct cycle plants are listed by Rossie and Cecil ${ }^{(3)}$.

TABLE 9. Power Plants with Direct-Cycle Cooling

\begin{tabular}{|c|c|c|c|c|}
\hline Plant & $\begin{array}{l}\text { No. of } \\
\text { Units }\end{array}$ & $\begin{array}{l}\text { Rating, a) } \\
\text { MWe. }\end{array}$ & $\begin{array}{c}\text { Air-Side } \\
\text { Environment }\end{array}$ & $\begin{array}{l}\text { Year on } \\
\text { Line }\end{array}$ \\
\hline Volkswagenwerk & 14 & 50 & Light Industrial & $\begin{array}{c}1961-67 \\
1970\end{array}$ \\
\hline \multirow[t]{2}{*}{ Neil Simpson } & 1 & 3 & Dry Rural (Mine Mouth) & 1962 \\
\hline & 1. & 22 & Dry Rural (Mine Mouth) & 1969 \\
\hline Union Termica & $i$ & 1.60 & Dry Rural (Mine Mouth) & 1970 \\
\hline
\end{tabular}

a) Rating for each unit

Steam passes directly from the turbine to the tower, where it curderises and returns to the boiler as condensate (Fig. 1-A).

All but one of the units shown in Table 9 were manufactured by GEA and are constructed of galvanized steel fins and carbon steel tubes and headers. The 3 MWe Neil Simpson (Wyodak) unit was manufactured by Griscom Russell. It has aluminum fins, admiralty tubes and steel headers. 
The water chemistries of the three plants are compared in Table 10.

\subsubsection{Steam/Water Corrosion Performance}

Volkswagenwerk: Slight internal scale formed on the tower tube surfaces, but this does not cause operational problems. No other corrosion problems have occurred. The exhaust steam from the turbine contains $210 \%$ : moisture, but no erosion of tubes or piping has been observed. Anticipated plant life is 225 years.

Freezing problems have occurred at the Volkswagenwerk during periods of heavy extraction steam requirements which resulted in low steam flow to the condenser. The problem has been solved by maintaining the condensate temperature above $5^{\circ} \mathrm{C}\left(41^{\circ} \mathrm{F}\right)$ when the air temperature reached $0^{\circ} \mathrm{C}\left(32^{\circ} \mathrm{F}\right)$. This is accomplished by keeping the condenser loaded to approximately 40,800 to $45,400 \mathrm{~kg} / \mathrm{hr}(90,000$ to $100,000 \mathrm{lb} / \mathrm{hr})$. of steam and by switching the fans on and off more frequently than had been done before. Subsequent tests have shown that the condenser steam load can be reduced to about $22,700 \mathrm{~kg} / \mathrm{hr}(50,000 \mathrm{lb} / \mathrm{hr})$ without freezing.

Union Termica: No corrosion or scaling problems have occurred to April 1975. Plant availability has been $7000 \mathrm{hr} / \mathrm{yr}$ (80\%) sillie 1970; down.time has not been caused by problems related to the dry tower.

Neil Simpson: In the 3-MWe unit, deposition on the turbilie has occurred due to sulfite carryover. At current sulfite concentrations, deposition is not a problem. No other corrosion problems have occurred.

In the 22-MWe unit, some iron sludge buildup has occurred in the boiler, but acid cleaning has been required only once since 1969. Iron oxide deposits have occurred on the turbine. Iron transport appears to contribute substantially to the iron oxide buildup in the boiler. The relative contribution of iron oxide from boiler corrosion and corrosion product transport frum the tower is not clear. Visual inspection indicates some dark iron oxide deposits on internal surfaces of the tower tubes and also in the hot well, suggesting the presence of a protective magnetite film. Plant availability has been $297.5 \%$ since the 1969 startup. 
TABLE 10: Water Chemistry at Operating Direct-Cycle Plants

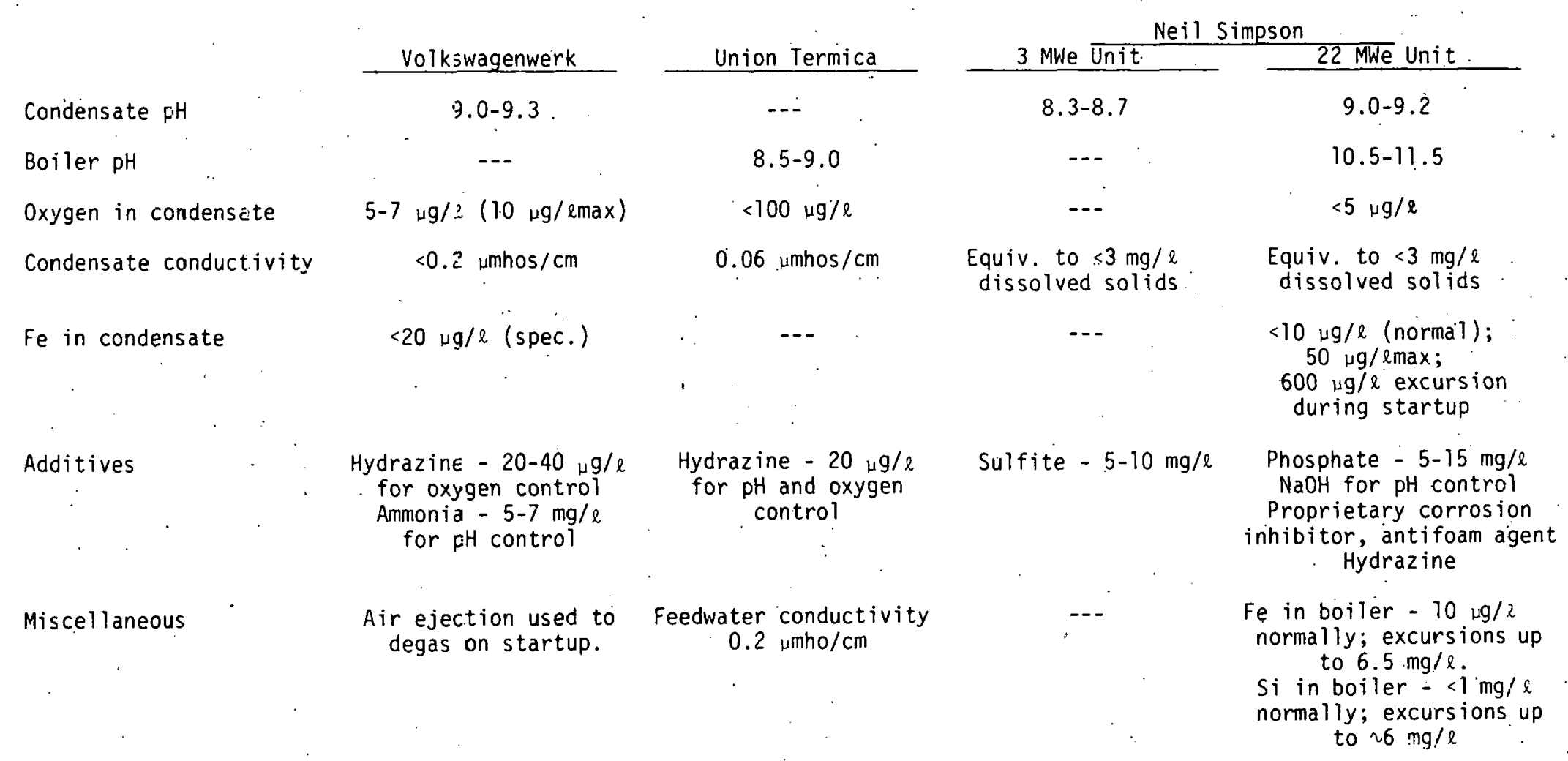


In summary, oxygen concentrations in the direct cycle condensate normally range from 5 to $10 \mu \mathrm{g} / 1$. Condensate conductivities range from 0.06 to $0.20 \mu \mathrm{mho} / \mathrm{cm}$, which corresponds to dissolved solids contents of about 50 to $150 \mu \mathrm{g} / 1$. Though the units operate below atmospheric pressure, no air inleakage problems have occurred. None of the units use condensate polishing.

\subsubsection{Air-Side Corrosion}

None of the direct cycle plants have experienced significant air-side corrosion of the galvanized surfaces in exposures up to 14 years, nor has there been any significant air-side corrosion of the aluminum fins at the Neil Simpson Station.

\subsection{INDIRECT CYCLE PLANTS}

Indirect cycle central power stations included in the survey include the Rugeley Station at Rugeley, England, the Preussag Plant at Ibbenbüren, Germany, the Gyöngyös Station at Gyöngyös, Hungary, and the Razdan Station at Razdan, USSR (Table 11; See also Fig. T-B). All the plants are of the Heller-Forgo design ${ }^{(3)}$. The design involves a carbon steel spray condenser with stainless steel nozzles, which inject cooled condensate into steam exiting from the turbines to condense it. The condensate is pumped to the cooler to dissipate the heat absorbed from the steam. The tower has aluminum tubes and plate-type aluminum fins. The tubes are vertical and the fins are horizontal. Water chemistries are summarized in Table 12.

TABLE 11. Power Plants With Indirect Cycle Cooling

\begin{tabular}{lcccccc}
\multicolumn{1}{c}{ Plant } & $\begin{array}{c}\text { No. of } \\
\text { Units }\end{array}$ & $\begin{array}{c}\text { Rating } \\
\text { MWe }\end{array}$ & & \multicolumn{1}{c}{$\begin{array}{c}\text { Air-Side } \\
\text { Environment }\end{array}$} & & Startup Date \\
Rugeley & 1 & 120 & & Marine, Industrial & & 1962 \\
Ibbenbüren & 1 & 150 & & Light Industrial & & 1967 \\
Gyöngyös & 2 & 100 & & Dry Rural & & 1969 \\
Gyöngyös & 2 & 200 & & Dry Rural & $\cdots$ & 1972 \\
Razdan & 3 & 220 & & Light Industrial & $\cdots$ & $1970-72$
\end{tabular}




\section{TABLE 12. Water Chemistry at Operating Indirect-Cycle Plants}

Rugeley

Condensate $\mathrm{pH}$

Boiler pH

Oxygen in Circulating Water $100-300 \dot{\mu g} / 1$

Oxygen in Boiler Feedwater

Fe in Condensate

$20 \mu \mathrm{g} / \mathrm{l}$

A1 in Condensate

$20 \mu \mathrm{g} / 1$

$10-20 \mu \mathrm{g} / \mathrm{T}$

At in Boiler Feedwater

Conductivity of Condensate $1.5-2.0 \mu \mathrm{mhos} / \mathrm{cm}$ Additives
Morpholine$3.3 \mathrm{mg} / 1$ residual

\section{Ibbenbüren.}

$7.8-8.0$

$$
\begin{gathered}
100-300 \mu \mathrm{g} / 1 \\
10-20 \mu \mathrm{g} / 1 \\
10 \mu \mathrm{g} / 1 \\
20 \mu \mathrm{g} / 1 \\
2 \mu \mathrm{g} / 1
\end{gathered}
$$

$0.3 \cdot \mu \mathrm{mhos} / \mathrm{cm}$

Hydrazine$50 \mu \mathrm{g} / \mathrm{l}$ residual

\section{Gyöngös \\ $6.8-7.0$}

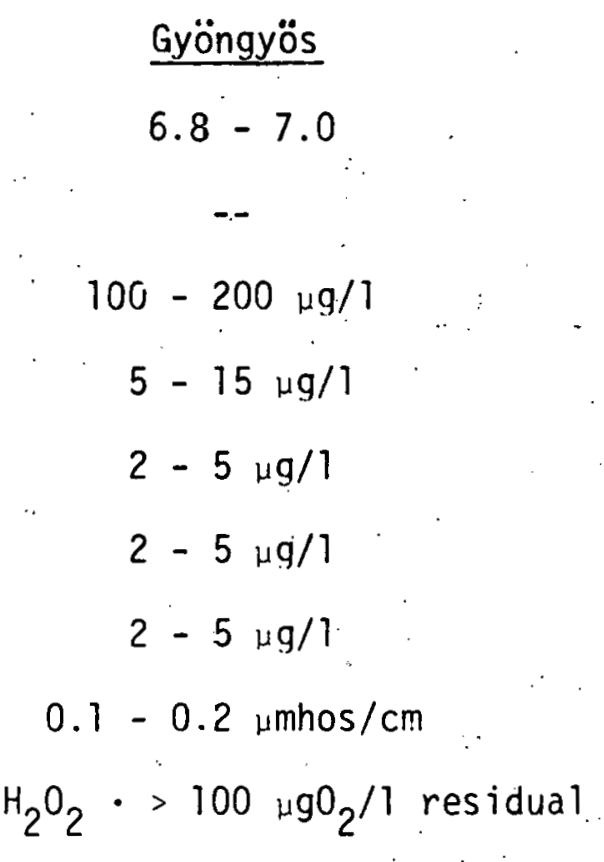




\subsubsection{Aqueous Corrosion}

A11 of the above plants employ Forgo-type cooling coils constructed of aluminum. The Forgo coil is constructed by placing an aluminum collar over each aluminum tube, followed by a section of the aluminum plate fin. The collars and fins are stacked alternately on the tubes until each coil is completed, at which time the fins and collars are tightly pushed together by a hydraulic press; then an expanding mandrel is drawn through the tubes, resulting in a tight mechanical burd belween tubes, collars and fins ${ }^{(3)}$. The tube bundles are mounted vertically, resulting in a horizontal fin position. The spray condenser and circulating water piping are constructed of carbon steel. Water boxes at each end of the condenser supply condensate to 24 stainless steel spray nozzle header pipes running across the condenser shell.

The use of both aluminum and steel in the circulating water circuit requires careful water chemistry control to prevent corrosion of both materials. The optimum $\mathrm{pH}$ for water in contact with aluminum is between 5.0 and $8.0^{(17)}$ with the $\mathrm{pH}$ of minimum corrosion being about 6.0 to $6.5^{(18)}$. Values of $\mathrm{pH}$ higher than about 8.0 cause a rapid increase in the aluminum dissolution rates. For maximum protection of steel, the condensate $\mathrm{pH}$ should be maintained above 8 8.5. At Rugeley the $\mathrm{pH}$ of the circulalion water is maintained in the lower range to minimize aluminum corrosion; the steel surfaces are coated with plastic to prevent steel corrosion due to the relatively low $\mathrm{pH}$ conditions. Aluminum in the condensate has varied between 10 to $20 \mathrm{\mu g} / \ell$, while soluble iron has remained at $20 \mu \mathrm{g} / \mathrm{\ell}^{(5)}$. No water-side corrosion problems or deposits are reported at Rugeley.

The Ibbenbüren plant has experienced a variety of feedwater chemistry problems. With the $\mathrm{pH}$ of the condensate malntained at 8.5 and above by hydrazine injection, aluminum content increased sharply as indicated in Fig. $8 .^{(5)}$ More precise $\mathrm{pH}$ control between 7.8 and 8.0 reduced soluble aluminum to $20 \mu \mathrm{g} / \mathrm{l}$; expected tube 1 ife is $20-30$ years based on this low solubility. 
Other workers have found that aluminum is not affected by hydrazine in the condensate. (19) Binger, et al., showed that the corrosion rate of aluminum is low in ammonia solutions at high $\mathrm{pH}^{(20)}$ and stated that at the concentrations normally employed, volatile amines added to boiler water for $\mathrm{pH}$ control have virtually no effect on the performance of aluminum alloys. $(21,22)$ It is not clear whether the increased solubility of aluminum with increasing $\mathrm{pH}$ at Ibbenbiiren was due to the higher hydrazine concentration or some to other reason, such as the possible presence of extraneous copper ions in solution.

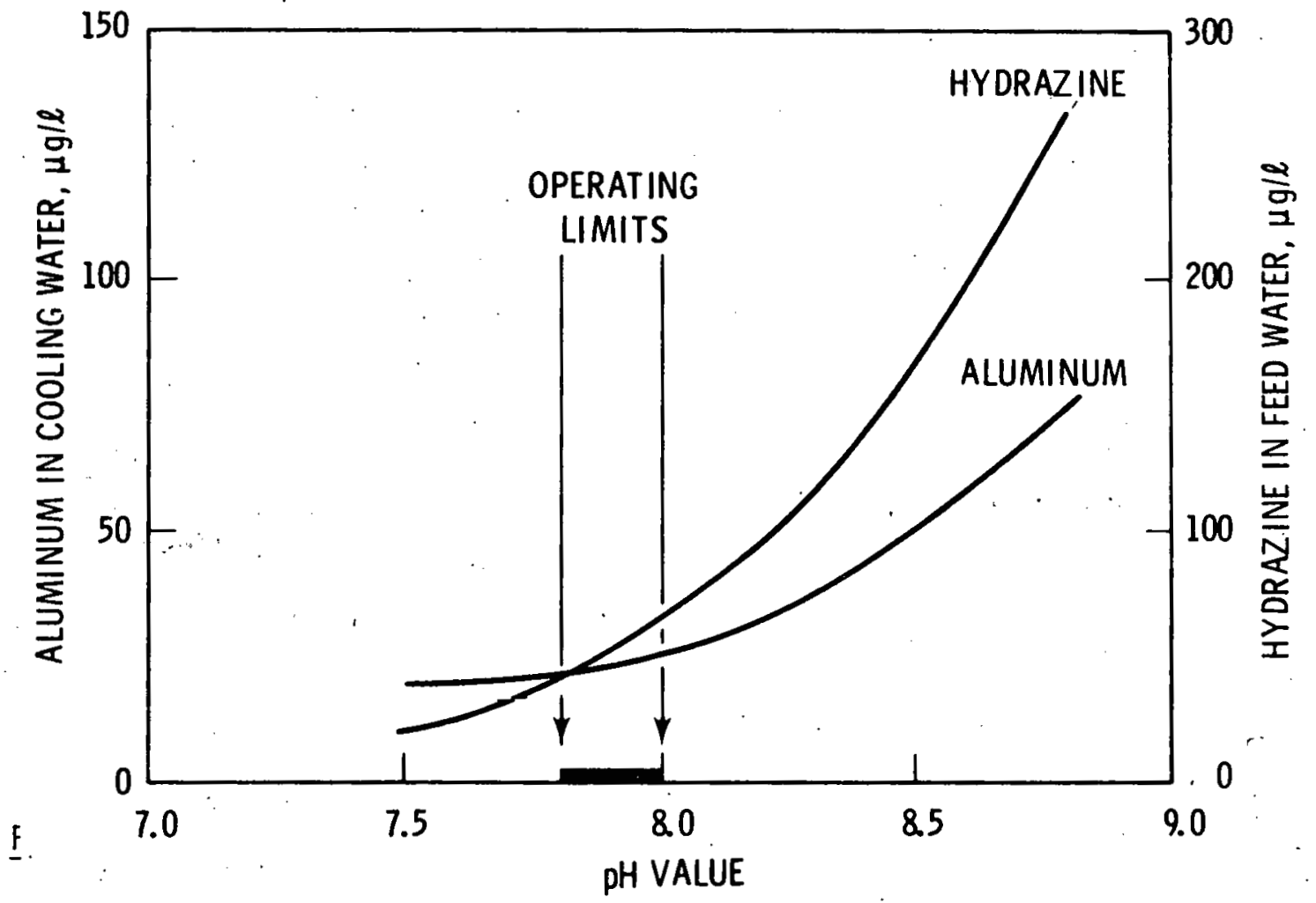

FIGURE 8. Effect of pH (Hydrazine Content) on Aluminum in Circulating water, Ibbenburen (5). 
Before going to the boiler, the condensate at Ibbenbiuren is passed through asbestos-coated screen filters, which reduce the aluminum content. to $10 \mu \mathrm{g} / \ell_{\text {.. }}$ Cation/anion demineralizers reduce the aluminum content to ..... $2 \mu \mathrm{g} / \ell^{(3)}$.

Concerning the effect of dissolved copper on the corrosion rate of aluminum, Heller reported no difficulty with accelerated corrosion of aluminum surfaces in spite of the fact that the aluminum-tubed air-cooled condenser under'study shared copper-bearing condensate from surface condenser cooled units. (5) on the other hand, in laboratory tests conducted at Ibbenbüren, aluminum content of simulated condensate $(\mathrm{pH} 7.0-9.0)$ reached high concentrations, ranging up to $4 \mathrm{mg} / \mathrm{l}$. It was determined that the high aluminum corrosion rate resulted from a brass pump in the test installation; the presence of copper ions caused the aluminum to corrode. (3). As a result of this study, the use of copper alloy products was avoided in the thermal and cooling tower cycles of the 150-MW unit at Ibbenbüren.

Visual inspection of the water system and condenser internal surfaces after operation for one year indicated no pitting or other corrosion problems at Ibbenbüren.

At Razden a problem with deposition of iron oxide on the internal surfaces of the aluminum tubes on the cooling tower has caused plant personnel to comtemplate plating the Internal surfaces of lhe slet piping with an aluminum metallized paint to produce similar internal surfaces throughout the system. It is anticipated that the aluminized coating would be approximately 25 microns thick and have a service life of $25-30$ years.

Water chemistry at Razden intially was similar to that at Rugeley and Ibbenbüren. (13) Now, however, the plant operators are contemplating conversion to a system of water chemistry control similar to that used at Gyöngyös, as described below.

The Gyöngyös Station is successfully using the "neutral method of operation" as a solution to the problem of protecting both aluminum and steel surfaces in the cooling tower circuit (23). This consists of operating the boiler water, feedwater and condensate at very low dissolved 
solids concentrations $(20.1 \mu \mathrm{mho} / \mathrm{cm})$ and neutral $\mathrm{pH}$. In the cooling tower circuit the oxygen concentration is maintained between 150 and 200 $\mu \mathrm{g} / 1$; this oxygen concentration causes passive iron oxides to form on the steel surfaces, preventing further corrosion. Laboratory and operating plant tests conducted by Brush and Pearl ${ }^{(24)}$ and other workers $(25,26)$ have shown that carbon steel and stainless steel corrosion can be inhibited by keeping oxygen concentrations in neutral water at $15-2000 \mu \mathrm{g} / 1$ in the temperature range of $28^{\circ} \mathrm{C}-204^{\circ} \mathrm{C}\left(100^{\circ} \mathrm{F}-400^{\circ} \mathrm{F}\right)$. Corrosion product release in this water chemistry regime is only half that found when the oxygen level is $3 \mu \mathrm{g} / 1$ or below. At temperatures above $250^{\circ} \mathrm{C}\left(482^{\circ} \mathrm{F}\right)$, oxygen must be completely eliminated to prevent corrosion of steel surfaces; therefore, oxygen must be removed from feedwater before it goes to the boiler ${ }^{(23)}$.

The "neutral method" of operation was at first unsuccessful at Gyöngyös due to the relatively high $(20.5 \mu \mathrm{mho} / \mathrm{cm})$ dissolved solids content of the circulating water. The high purity water necessary for successful use of this method could only be obtained by condensate polishing. Equipment for this treatment is less expensive for a plant using dry cooling because cooling water inleakage is not a factor; therefore, impurity control is less difficult than it is in a plant where once-through cooling is used.

Since the installation of condensate polishing equipment at Gyöngyös, the "neutral method of operation" has been used successfully. No corrosion product transport or deposition in the boilers and turbines has been detected.

\subsubsection{Air-Side Corrosion}

of the four plants using the indirect (Heller) system, only the Rugeley Station has reported serious air-side corrosion. The cooling coils at Razden must be cleaned periodically to remove cement dust deposition from a nearby plant ${ }^{(13)}$, but no apparent problems have resulted from this situation.

The Preussag plant at Ibbenbüren has serious fouling problems resulting from proximity to pulverized coal storage areas and wet cooling towers ${ }^{(16)}$. The situation is aggravated by the notched fins, which act as effective dirt 
traps. Since the aluminum Forgo-type fins cannot withstand cleaning by pressurized water, cleaning with pressurized air has been attempted severai times with negligible effect. Removal of the bundies and cleaning in sul-" furic acid may be necessary. Preliminary metallographic examinations show that corrosion of the aluminum fins is occurring beneath the caked coal dust. The combination of fouling and corrosion has reduced the heat 'rejection capacity of the Ibbenbüren plant to $72 \%$ after eight years of operation.

The Rugeley plant has experienced serious air-side corrosion. The station is located at the site of a coal mine and is also adjacent to an ash sin:= tering plant which makes light weight aggregate from the plant ash. Also, the dry tower is in close proximity to four evaporative towers and is subject to drift and spray. from them. Within a short time after startup, serious corrosion occurred in crevices between the cooling coil fins and the spacer collars. This corrosion eventually resulted in perforation of the tubes. The problem is attributed to high humidity, evaporative tower drift and atmospheric pollutants, the principal active ingredients being moisture and chlorides $(27)$. Despite the tight mechanical joints between the fins and spacer collars, moisture containing chlorides penetrated the minute crevices and set up active corrosion cells behind the collars, causing pitting and finally perforation of the aluminum tube walls. Moisture kept these cells active, and the bulky corrosion products distorted the tubes locally. The corrosion eventually became widespread on the weather-side tubes, particularly in coolers that had been out of service for a period.

As an attempted solution to the Rugeley corrosion probleill, all epoxy coating was selected as the best method to protect the coolers from airside corrosion. At the present time, all of the cooling colls at the Rugeley Station have been treated with the epoxy coating. However, air-side corrosion of the cooling coils is still continuing; the more recent problems are attributed to a difference in coil design which introduced a collar which prevented adequate coverage by the epoxy coating, leaving a thinly-coated local area which remained vulnerable to air-side corrosion. A method has been developed for sealing the leaks at a very low cost; the procedure does not involve dismantling or down time. 


\section{SURVEY OF PUBLISHED CORROSION DATA}

Corrosion of dry-cooled equipment, including the condenser, piping, air cooler tubes and fins, falls into two broad categories:

- water and/or steam corrosion of interior surfaces;

- atmospheric corrosion of exterior surfaces.

The foregoing survey of industrial experience indicates that corrosion has been a minimal problem in air-cooled equipment. The fact that some cases of severe corrosion have occurred demonstrates a need to identify and avoid conditions which lead to untimely replacement or substandard operation of air coolers and related equipment in large electrical generating plants. This report briefly summarizes from the literature, atmospheric and aqueous corrosion data which are relevant to the dry cooling tower regime, $\sim 45-65^{\circ} \mathrm{C}\left(120-150^{\circ} \mathrm{F}\right)$ and while the plant is at ambient temperatures. Several corrosion mechanisms shown below will be considered in this treatment, including the following:

- stress corrosion cracking

- intergranular attack

- corrosion fatigue

- pitting

- de-alloying phenomena
- galvanic attack

- uniform corrosion

- crevice corrosion

- erosion corrosion

- fretting corrosion

This report does not attempt to treat each mechanism in depth nor can it hope to identify all operating regimes where the potential failure mechanisms may be significant to power plant dry cooling system corrosion technology; rather, it establishes an initial basis for discussion and further definition of the above mechanisms and others which may prove to be important. The mechanisms could apply either to corrosion of exterior or interior surfaces, though not equally in all cases. Other considerations such as corrosion product transport and deposition apply principally to interior surfaces, but may have some significance to exterior surfaces in deluge systems. Isolated cases of several of the failure mechanisms 1 isted above have occurred in operating dry-cooled equipment (see Section 1). However, the impacts have been minor to this point. On the other hand, it is important to identify and avoid operating regimes where corrosion faitures can occur. 
The following sections will consider aqueous and atmospheric corrosion of state-of-the-art dry cooling tower materials.

\subsection{WATER-SIDE CORROSION OF CANDIDATE MATERIALS}

\subsubsection{Candidate Materials}

Table 13 shows the candidate materials for the various water-side applications in dry-cooled systems. While it may be possible to use each material in the application checked, all characteristics of each material (such as corrosion behavior, heat exchanger properties, ease of handling, cost, etc.) must be considered in making the materials selections. The relative costs of these materials are given in Appendix B. Only corrosion behavior of these materials will be examined in detail here.

Titanium is finding increasing use as a condenser tubing material, particularly in aggressive water-side environments. It has been projected that by 1985 titanium will account for about one-quarter of the condenser market. However, in closed systems such as the dry cooling circuits where water chemistry is controllable, titanium will probably not be considered because of its high relative cost (see Appendix $B$ ). In these less aggressive environments, aluminum becomes more attractive for surface condenser applications because of cost considerations.

Attention must be given to the combinations of materials used in the condensing and/or cooling systems. For example, combinations of copper-base alloys and aluminum alloys in the same system (such as a copper-alloy condenser and an aluminum-tubed dry cooling tower) should be avoided because of aluminum corrosion caused by copper ion dissolution in circulating water and subsequent deposition on the aluminum surfaces, forming numerous local galvanic cells. In closed systems, the problem can be reduced by use of organic phosphorus compounds as a corrosion inhibitor. Such inhibitors cannot be used in steam condensate, however. 
IABLE 13. CANDIDATE MATERIALS FOR DRY-COOLED SYSTEMS

\begin{tabular}{|c|c|c|c|c|c|}
\hline \multicolumn{2}{|c|}{ DIRECT CYCLE } & \multicolumn{4}{|c|}{ INDIRECT CYCLE } \\
\hline $\begin{array}{c}\text { Exhaust Steam } \\
\text { Piping } \\
\end{array}$ & $\begin{array}{l}\text { Cooling } \\
- \text { Coils } \\
\end{array}$ & $\begin{array}{l}\text { Contact } \\
\text { Cond. }\end{array}$ & $\begin{array}{l}\text { Surface } \\
\text { Cond. }\end{array}$ & $\begin{array}{c}\text { Condensate } \\
\text { Piping } \\
\end{array}$ & $\begin{array}{l}\text { Heat Exchanger } \\
\text { Piping } \\
\end{array}$ \\
\hline$x$ & $x$ & $x^{2}$ & $x^{2}$ & $x$ & $x$ \\
\hline$\cdot$ & $x$ & & $x$ & & $x$ \\
\hline & $x$ & , & $x$ & & $x$ \\
\hline . & $x$ & & $x$ & & $x$ \\
\hline$x$ & $x$ & $x$ & $x$ & $x$ & $x$ \\
\hline$x$ & $x$ & $x$ & $x$ & $x$ & $x$ \\
\hline & & & $x$ & & $x$ \\
\hline
\end{tabular}

1- Special water treatment must be used if copper-base alloys are used elsewhere in the circuit.

2- Proper engineering considerations must be employed to reduce erosion by saturated steam impingement. 
Combinations of aluminum and steel in the same system require careful measures to ensure protection of both metals from corrosion. This may be accomplished by striking a balance between the optimum $\mathrm{pH}$ values for each metal, coating the steel surfaces and operating at the optimum $\mathrm{pH}$ for the protection of aluminum, using corrosion inhibitors (in indirect systems with surface condensers) or employing the "neutral method of operation" as described previously.

\subsubsection{Aluminum Base Alloys}

\subsubsection{General Corrosion Behavior}

Aluminum is an attractive choice for heat excharyer material because of its light weight, high thermal conductivity, corrosion resistance, ease of fabrication and low relative cost. Examples of aluminum alloys employed in tubular heat exchangers are given in Table 14. Alcoa recommends aluminum alloy 6063-T832 for condenser tubing, citing its excellent corrosion resistance and higher resistance to erosion than other aluminum alloys $(29)$.

TABLE 14. Examples of Aluminum Alloys Used For Tubular Heat Exchangers

\begin{tabular}{ll} 
Alloy No. & \multicolumn{1}{c}{ Nominal Composition } \\
1100 & $0.20 \mathrm{Cu}, 99.0 \mathrm{Al}$ \\
3003 & $1.2 \mathrm{Mn}, 0.12 \mathrm{Cu}$ \\
5052 & $2.5 \mathrm{Mg}, 0.2 \mathrm{Cr}$ \\
5454 & $2.6 \mathrm{Mg}, 0.7 \mathrm{Mn}, 0.10 \mathrm{Cr}$ \\
6061 & $1.0 \mathrm{Mg}, 0.25 \mathrm{Cu}, 0.6 \mathrm{Si}, 0.20 \mathrm{Cr}$ \\
6063 & $0.65 \mathrm{Mg}, 0.40 \mathrm{Si}$ \\
Alclad & \\
J003, 3004 & $1.0 \mathrm{Zn}, 99.0 \mathrm{Al}$. bunded lo Alloy 3003 or 3004
\end{tabular}

While its position in the Electromotive Force Series would classify it as an active metal, aluminum becomes passive when exposed tu water and other oxidizing media due to the formation of a protective oxide file ${ }^{(17)}$. The growth and destruction of this film is the controlling feature of 
aluminum corrosion. Dissolved oxygen in water improves the corrosion resistance of aluminum, but oxygen is not necessary for passivity to occur. Aluminum is well-suited for handling steam and steam condensate containing carbon dioxide or oxygen because aluminum is more resistant to these contaminants than copper-base and iron-base materials (22). Horst and Marchese indicate that aluminum is not affected by oxygen scavengers such as hydrazine in the condensate, and that it is more resistant than admiralty brass to ammonia attack in the air-cooler section of condensers (19). This is an agreement with the work of others $(20,21,22)$. However, increased corrosion of aluminum at Ibbenbüren may have been due to high pH maintained by hydrazine ${ }^{(5)}$. At the concentrations normally employed, volatile amines (such as ammonia and morpholine) added to boiler water for $\mathrm{pH}$ control and filming amines added for corrosion control have virtually no effect on the performance of aluminum alloys $(21,22)$.

In contrast to the generally good corrosion performance of aluminum found by investigators cited above, a: study by the Marley Company, cited earlier, resulted in relatively high corrosion rates ${ }^{(14)}$. The corrosion behavior of several materials was investigated including aluminum-and copper-base alloys exposed to steam condensate at velocities and temperatures typical of a dry tower system operating in a super-critical steam cycle $\left(1.6 \mathrm{~m} / \mathrm{sec}, 60^{\circ} \mathrm{C}\right.$ ). The corrosion of all aluminum tube samples (alloys 3003, 5052, 6061, and Alcald 3004) ranged between 3.5 and $4.0 \mathrm{mils}$ after six months exposure $\left(13-15 \mathrm{mg} / \mathrm{dm}^{2} /\right.$ day $)$ based on average weight loss $(14)$. Other workers $(18,21,30,31)$ have determined aluminum corrosion rates on the order of $0.07 \mathrm{mg} / \mathrm{dm}^{2} /$ day under similar temperature and flow conditions. Horst and Marchese $(19)$ point out the care that must be exercised in interpreting laboratory data because of the problem of accurately simulating operating conditions. This is particularly true in the determination of aluminum corrosion rates if the possibility exists of contamination of the test water with even trace amounts of copper. The fact that a copper alloy heat exchanger existed in the Marley test circuit suggests this possibility.

Rates of aluminum corrosion in pure water are reduced to $0.04 \mathrm{mg} / \mathrm{dm}^{2} \cdot /$ day in $10^{-3} \mathrm{~N}(? 15 \mathrm{mg} / 1) \cdot \mathrm{H}_{2} \mathrm{O}_{2}$ and sti1l lower by $2 \mathrm{mg} / 1 \mathrm{~K}_{2} \mathrm{Cr}_{2} \mathrm{O}_{7}{ }^{(32)}$ : 


\subsubsection{Effect of Temperature}

In neutral, deaerated distilled water, the corrosion rate of Type 1100 aluminum increases with increasing temperature, but at $70^{\circ} \mathrm{C}$ that rate is still very low, about $0.07 \mathrm{mg} / \mathrm{dm}^{2} /$ day $(18)$. Thus, at the temperatures encountered in surface condensers and power plant dry-cooled heat exchangers, aluminum alloy corrosion is.generally acceptable in low velocity steam and high purity steam condensate, with or without oxygen and carbon dioxide (19).

Aluminum corrosion in high purity water is chararterized hy an initial period of relatively rapid corrosion, followed by a constant lower rate of corrosion. The attack is uniform and without marked pitting. Corrosion rates of aluminum alloy 1100 in distilled water at various temperatures are shown in Figure $9^{(18)}$. At the temperatures relevant to the dry, cooling regime, the corrosion rate of aluminum alloys in deionized water varies by an inverse logarithmic relation with time $(33,34)$.

A thermally induced intergranular failure mechanism occurs in many aluminum alloys in water above $200^{\circ} \mathrm{C}$ but does not occur at dry cooling tower temperatures $(35,36)$.

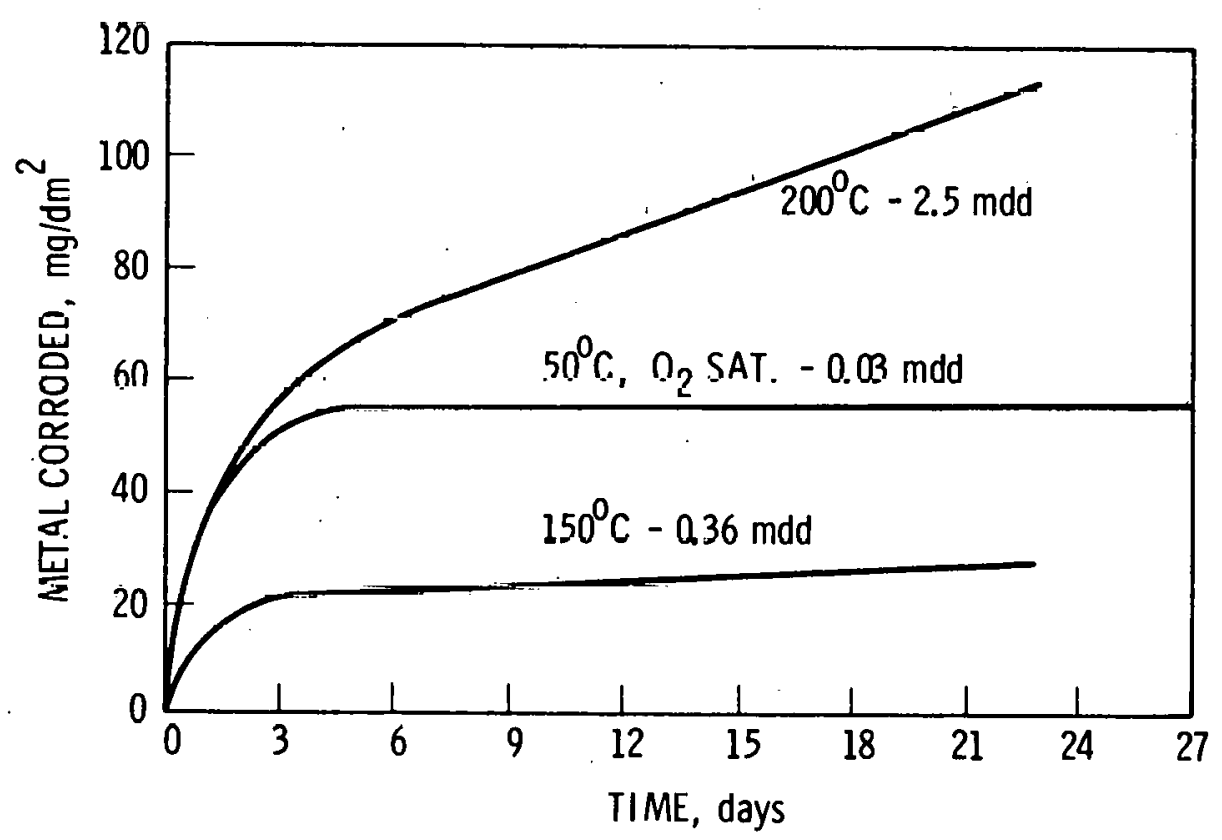

FIGURE 9. Corrosion of Aluminum Alloy 1100 in Continuously Refreshed Distilled Water (18). 


\subsubsection{Effect. of $\mathrm{pH}$}

The $\mathrm{pH}$ of minimum corrosion of aluminum in high purity water is temperature dependent. Below $100^{\circ} \mathrm{C}$ the $\mathrm{pH}$ of minimum corrosion is in the general vicinity of 6.0 to 6.5 ( $\mathrm{pH}$ measured at room temperature $)^{(18)}$. For oxygen-saturated solutions at $50^{\circ} \mathrm{C}$, Draley and Ruther found the minimum corrosion rate $\left(0.03 \mathrm{mg} / \mathrm{dm}^{2} /\right.$ day) to occur in neutral (pH 7) water. Their findings are illustrated in Figure 10.

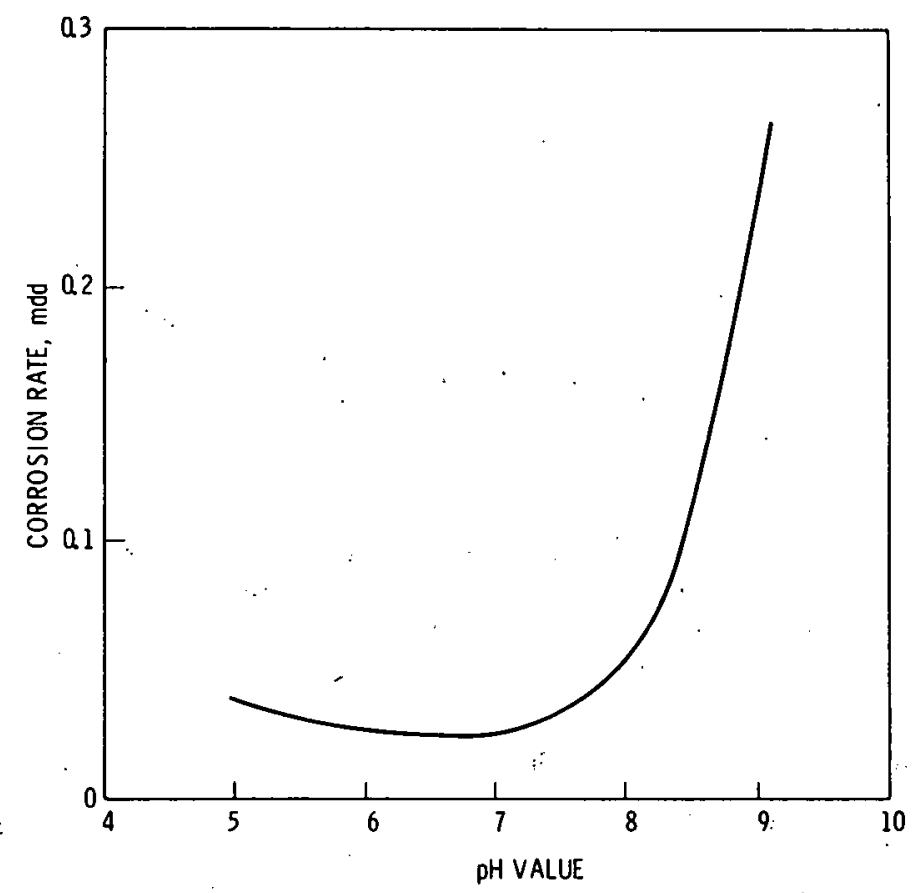

FIGURE 10. Corrosion of Aluminum Alloy 1100 in 0xygen-Saturated Solutions at $50^{\circ} \mathrm{C}$ (18).

Binger and Marstiller (22) found the minimum rate of corrosion to occur at about $\mathrm{pH} 4$ for alloy $3003-\mathrm{H} 14$ in $60^{\circ} \mathrm{C}$ water (see Fiqure 11). Draley and Ruther (18). noted that mild pitting took place in autoclave

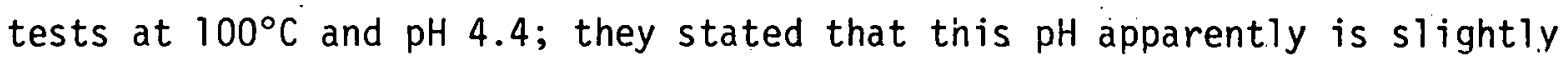
low for adequate resistance to corrosion at this temperature.

The $\mathrm{pH}$ of minimum corrosion is sensitive to oxygen content; being highest in oxygen-saturated water (17). The corrosion rate is reduced and spallation of the oxide film is prevented by saturating the water with oxygen. 
Increasing the $\mathrm{pH}$ above that at which minimum attack occurs generally makes aluminum more susceptible to corrosive effects of solution velocity. Apparently this effect is due to the increasing solubility of the corrosion product as the $\mathrm{pH}$ increases. The $\mathrm{pH}$ of minimum attack tends to decrease as the temperature increases $(18)$.

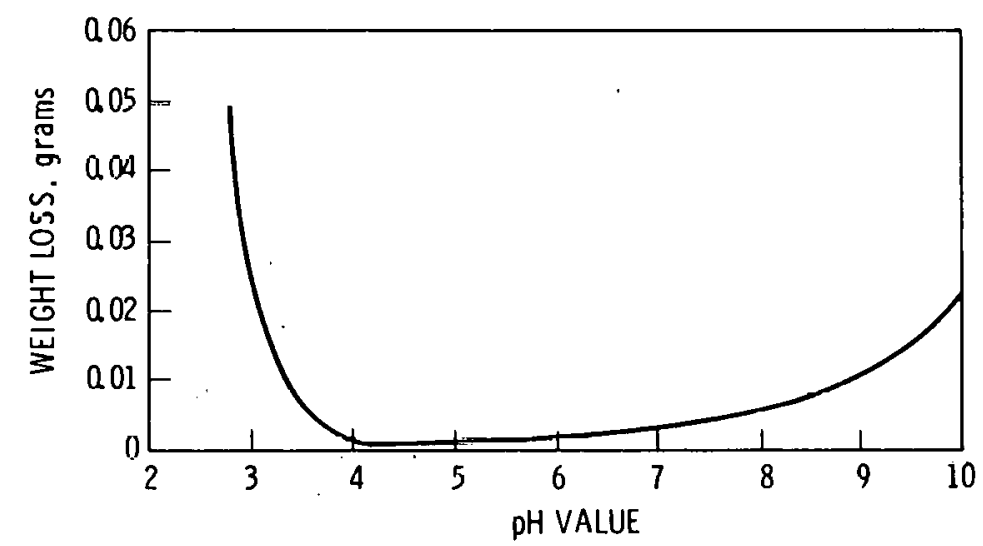

FIGURE 11. Effect of pH of Distilled Water on the Weight Loss of Aluminum Alloy 3003-H14 Specimens (1.6 mm x $12.7 \mathrm{~mm} \times$ $76.2 \mathrm{~mm}$ ) Exposed at $60^{\circ} \mathrm{C}$ for 1 Week $(22)$.

In water with a pH of 8.5 or more, the corrosion resistance of aluminum depends primarily on the nature of the compounds causing the high pH. Figure 12 from Binger, et al ${ }^{(20)}$ shows the dependence of aluminum corrosion on $\mathrm{pH}$ and indicates that the corrosion rates vary substantially with the anionic and cationic species used for $\mathrm{pH}$ control.

As noted previously $(19,21,22)$, high $\mathrm{pH}$ caused by ammonia and other amine compounds is significantly less detrimental than that caused by other alkaline compounds. Thus aluminum: is compatible with ammonia and volatile amines used for boiler $\mathrm{pH}$ and oxygen control.

\subsubsection{Corrosion Mechanisms}

\section{Stress Corrosion Cracking}

Pure aluminum is immune to stress corrosion cracking ${ }^{(32)}$. Certain aluminum alloys and tempers are or can become susceptible to stress corrosion cracking, but these are not selected for air cooler service. 


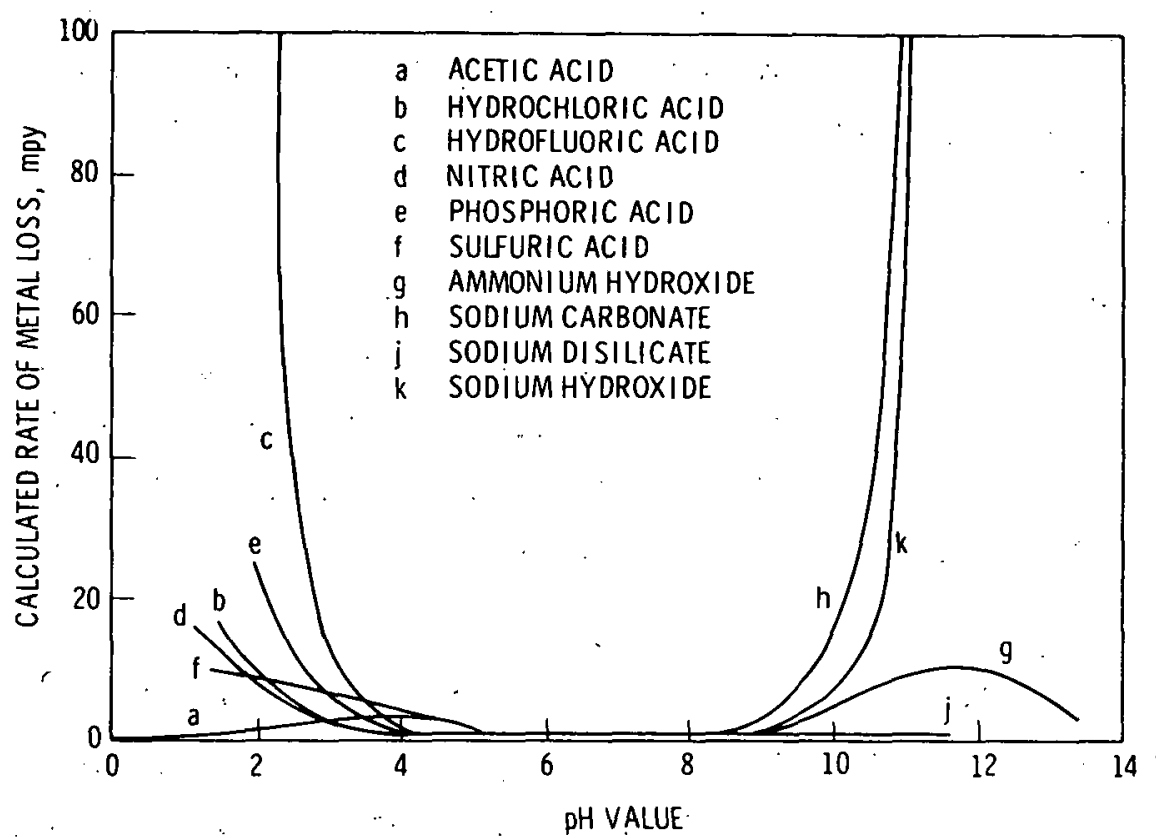

FIGURE 12. Effect of $\mathrm{pH}$ on Corrosion of Aluminum A1loy 1100-H14 by Various Chemical Solutions(20).

Of the aluminum alloys commonly used for tubular heat exchangers (see Table 14), none is subject to stress corrosion cracking in normal usage. High strength alloys in the $2 x x x$ and $7 x x x$ series are not recommended for tubular heat exchanger service because of susceptibility to stress corrosion cracking (37), and lower resistance to general corrosion.

\section{Intergranular Attack}

Intergranular attack in aluminum alloys arises when cathodic or anodic grain boundary precipitates develop as a result of thermal treatments. Aluminum-base magnesium alloys with less than $3 \% \mathrm{Mg}$ are not affected. The 6061 and 6063 alloys may show a minor degree of intergranular attack, but the chromium present has a tendency to offset this. The 3003 alloy is not normally affected.

The temperature above which intergranular corrosion of practical significance occurs is cited as being between 125 and $275^{\circ} \mathrm{C}(18,32,38)$, depending on the environment. Iron and nickel in the alloy is highly beneficial in retarding this effect or raising the temperature at which it 
begins ${ }^{(38)}$. However, the aqueous intergranular attack of aluminum is not expected to be a problem in the lower temperature regimes $\left(60^{\circ} \mathrm{C}\right)$ expected in dry cooling applications.

\section{Crevice Corrosion}

In a recent review, Godard et al ${ }^{(39)}$ concluded that crevice attack is not generally responsible for significant deterioration of aluminum. Crevice corrosion in the atmosphere and fresh water was considered negligible. On the other hand, when aluminum was exposed to sodium chloride solutions the corrosion rate in crevices was ten times that outside the crevice in this experiment. (40)

While crevice corrosion is expected to be minimal in the high-purity water of dry-cooled systems, aluminum alloys in general are susceptible to this form of attack. Crevices should be eliminated by proper design of the system. Crevices between aluminum and other metals should be particularly avoided because of the possible combined effects of crevice and galvinic corrosion.

Pitting Corrosion

Pitting is not likely to develop on the water-side of dry-tower. heat exchanger tubing as long as the purity of the water is maintained. In high purity water at the temperatures of interest, aluminum has exhibited only minimal uniform attack. Draley and Ruther $(18)$ know of no instance of significant aluminum pitting in high purity water. There have been instances of localized attack in crevices between aluminum and materials cathodic to it, most likely due to decreased water purity in the crevice. Pitting will not occur on aluminum coupled to stainless steel if the water is sufficiently pure ${ }^{(41)}$.

In oxygen-saturated distilled water at $70^{\circ} \mathrm{C}$, micropits on the order of 20 microns form, but no gross pitting occurs $(42,43)$. These micropits do not grow in size, but their number increases. This is probably a localized, self-stifling reaction. Apparently, corroding aluminum repairs breaks in its protective oxide film if the water is sufficiently pure. 
Traces of $\mathrm{Cu}^{++}$(as little as $0.02 \mathrm{ppm}$ ) in water react with aluminum, depositing metallic copper at local sites. These metals set up tiny localized cathodes and both initiate pitting and stimulate pit growth by galvanic action. Again, if the water cannot be treated to reduce this problem, care must be taken to ensure high water purity; however, copper ions cannot be removed completely by conventional purification systems. Only by eliminating copper materials from a system containing aluminun can the latter material be fully protected from this form of attack. The effect is very pH sensitive; pitting resulting from copper ion plating decreases with increasing $\mathrm{pH}$ due to decreased solubility of copper. Pitting has occurred on the cooling water side of some once-through aluminum surface condensers, but is. much less likely to occur on aluminum in contact with steam condensate or inhibited waters.

\section{Erosion Corrosion}

- Experience with aluminum condenser tubes in steam surface condensers has shown that aluminum tubes should not be subjected to direct impingement of turbine exhaust steam ${ }^{(17)}$. Direct impingement of low quality steam on the upper banks of aluminum condenser tubes in a plant operated by Wisconsin Electric Power Company (WEPCO) caused erosion corrosion and resulted in boiler water concentrations of aluminum as high as $7 \mathrm{mg} / \mathrm{l}$. This relatively high concentration of aluminum, coupled with marginal circulation in the boiler waterwall tubes caused the formation of noselite scale $\left(4 \mathrm{Na}_{2} 0 \cdot 3 \mathrm{Al}_{2} 03 \cdot 6 \mathrm{SiO}_{2} \cdot \mathrm{SO}_{4}\right)$. Increasing boiler blowdown and raising boiler water pll effectively addressed this problem ${ }^{(44)}$. This problem can be avoided by the use of clip-on stainless steel sleeves on the first several rows of tubes or by the selective placement of stainless steel tubes in this area of the condenser. Massive tube failures however, due to waterside erosion corrosion, forced the replacement of all aluminum condenser tubes at WEPCo ${ }^{(44)}$.

On the water side of the condenser, erosion corrosion of aluminum tubes is sensitive to flow rate. In tests designed to examine this effect, the corrosion rate of aluminum in $\mathrm{pH} 7$ water flowing at $2.7 \mathrm{~m} / \mathrm{sec}$ ( $9 \mathrm{fps}$ ) increased when the temperature was increased from $70^{\circ} \mathrm{C}$ to $95^{\circ} \mathrm{C}\left(158\right.$ to $203^{\circ} \mathrm{F}$ ). 
However, decreasing the temperature to $80^{\circ} \mathrm{C}\left(176^{\circ} \mathrm{F}\right)$ and increasing the flow rate to $6.1 \mathrm{~m} / \mathrm{sec}(20 \mathrm{fps})$ resulted in higher corrosion rates $(18)$.

Aluminum condensers have operated satisfactorily at the design water velocity of $2.1 \mathrm{~m} / \mathrm{sec}(7 \mathrm{fps})^{(19,29)}$. WEPCo, however, experienced erosion corrosion problems at the inlet end of aluminum condenser tubes; this problem was attributed to inlet end turbulence,although velocities were in a range easily handled by conventional condenser materials. The first few inches of the tubes were spray painted in "an "effort to protect the inlet ends, but extraneous paint droplets deposited beyond the painted area caused rapid and extensive erosion damage. Despite these problems, aluminum surface condensers have operated satisfactorily provided the tubes are prulec led frum steam-side erosion, water velocities are relatively low, and water boxes are specially designed to prevent excessive turbulence ${ }^{(44)}$.

Galvanic Attack

The problems associated with aluminum/copper couples and copper contaminated waters in aluminum systems has already been mentioned, but these problems can be practically handled in closed systems by the use of organic phosphorus compound corrosion inhibitors. Waters containing significant amounts of dissolved nickel ( $>0.1 \mathrm{ppm})$ should also be approached with caution (19).

In pH 5 water at $100^{\circ} \mathrm{C}\left(212^{\circ} \mathrm{F}\right)$, flow rates of $0.15 \mathrm{~m} / \mathrm{min}(0.5 \mathrm{ft} / \mathrm{min})$ to $24.7 \mathrm{~m} / \mathrm{sec}(81 \mathrm{ft} / \mathrm{sec})$, pitting of aluminum resulted from contacts with several types of stainless steels ${ }^{(45)}$. This pitting, which occurred in contact areas only, was up to 13 mils in depth after one year.

Other workers $(46,47)$ also point out the severe localized corrosion which can occur at the point of the coupling when aluminum is coupled with copper, mild steel or stainless steel. The effect is temperature sensitive and is more pronounced in waters with increased conductivity. Most galvanic problems can be handled with proper attention to water treatment.

Horst and Marchese ${ }^{(19)}$ point out that galvanic action between aluminum tubes and steel tube sheets and water boxes is slight, but recommended practice is to coat the tube sheets and water boxes with a zinc-base paint to el iminate the large steel cathodic area and any likelihood of galvanic attack on aluminum tube ends. This coating should not be sprayed on the inside of 
the aluminum tubing in such a manner that extraneous paint droplets are formed on the metal surface; such droplets can result in serious cavitation damage $^{(29)}$.

\section{Corrosion Product Transport}

As cited previously, the aluminum corrosion rate in high purity water at $70^{\circ} \mathrm{C}\left(158^{\circ} \mathrm{F}\right)$ and neutral $\mathrm{pH}$ is approximately $0.07 \mathrm{mg} / \mathrm{dm}^{2} / \mathrm{day}(18)$. These same workers found that after an initial period of a few days, the amount of corrosion product from 1100 aluminum in water below the boiling point varies with the logarithm of time. The data in Table 15 below were obtained in high-purity $\left(10^{6} \mathrm{ohm}-\mathrm{cm}\right)$ water ${ }^{(31)}$. Intercept values are those extrapolated to one day.

\section{TABLE 15. Logarithmic Slopes and Intercepts for Corrosion of 1100 Aluminum in Water}

\begin{tabular}{|c|c|c|c|c|}
\hline \multirow[b]{2}{*}{ Temp, ${ }^{\circ} \mathrm{C}$} & \multicolumn{2}{|c|}{$\underline{0}_{2}=$ - saturated } & \multicolumn{2}{|c|}{$\mathrm{He}$ - saturated } \\
\hline & $\begin{array}{l}\text { Slope, } \\
\mathrm{mg} / \mathrm{dm}^{2} \text { - cycle }\end{array}$ & $\begin{array}{c}\text { Intercept, } \\
\mathrm{mg} / \mathrm{dm}^{2} \\
\end{array}$ & $\begin{array}{l}\text { Slope, } \\
\mathrm{mg} / \mathrm{dm}^{2}-\text { cycle }\end{array}$ & $\begin{array}{c}\text { Intercept, } \\
\mathrm{mg} / \mathrm{dm}^{2} \\
\end{array}$ \\
\hline 50 & 3.14 & 36.59 & 2.62 & 37.43 \\
\hline 70 & 3.60 & 37.55 & 3.48 & 38.48 \\
\hline 95 & 7.83 & 5.72 & 5.66 & 11.17 \\
\hline
\end{tabular}

While these numbers are important from the standpoint of the integrity of the metal itself. (they indicate that the corrosion rate of the aluminum in this environment is very low), they do not accurately reflect the amount of corrosion product that is released and transported throughout the system. Mori and Draley $(30)$ showed that for 1100 aluminum in $70^{\circ} \mathrm{C}$ oxygenated water, the corrosion product dissolved at a constant rate after the first five days to provide $11.9 \mu \mathrm{g} \mathrm{Al} / \mathrm{dm}^{2} /$ day in the water. Their data is plotted in Figure 13. 


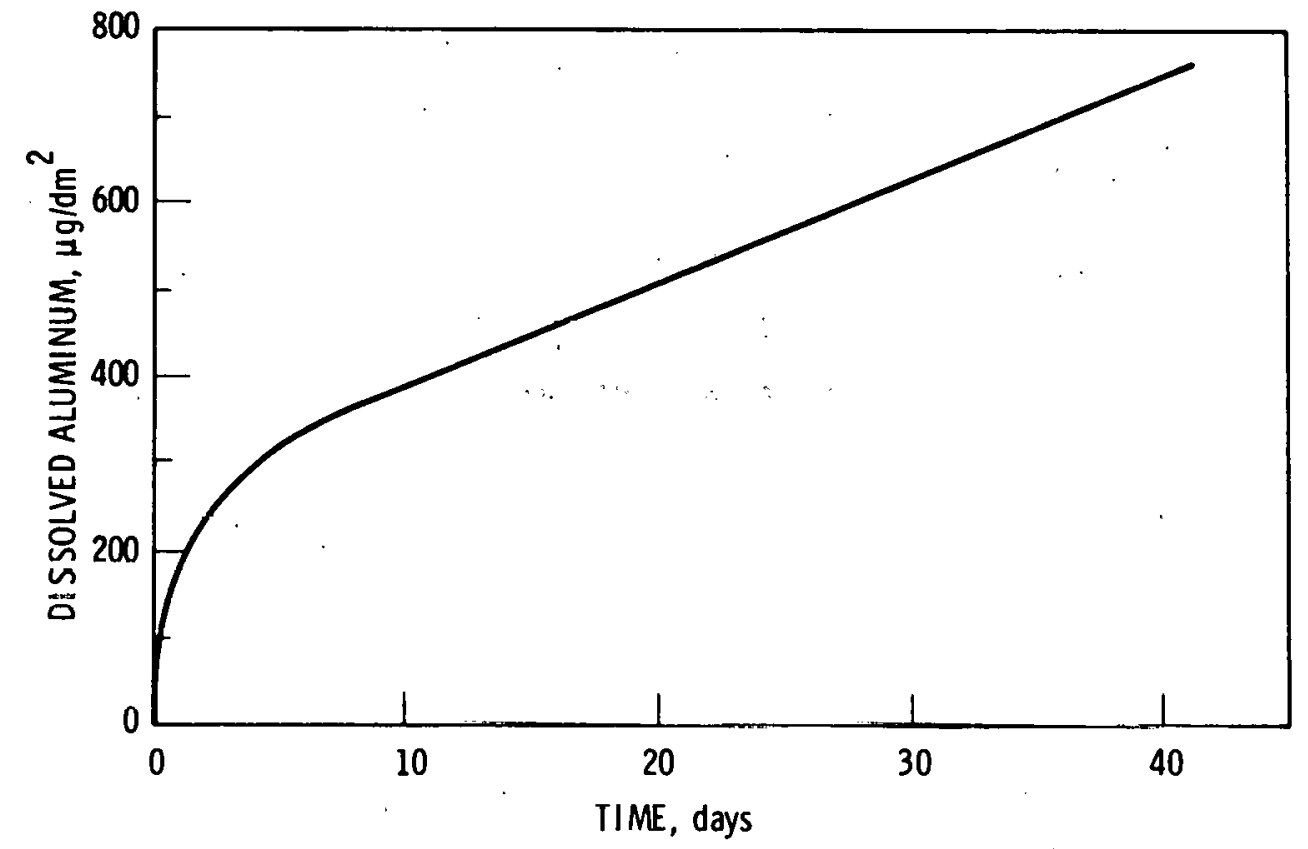

FIGURE 13. Weight Loss of Aluminum Alloy 1100 in Continuously Refreshed Water at $70^{\circ} \mathrm{C}(30)$.

Table 16 shows the estimated internal surface area and volume of the circulating water system of a typical 1000 MWe fossil plant using a surface condenser. Using these figures, the rate of corrosion product dissolution cited above, and the assumption that both the condenser and the dry cooling tower are constructed of aluminum, it is estimated that corrosion product release into the circulating water will amount to about $70 \mathrm{~kg}$ of aluminum per year. The majority of this corrosion product will be in a suspended or colloid form, probably as $\mathrm{Al}_{2} \mathrm{O}_{3}$..

Stumm and Morgan ${ }^{(48)}$ give the data in Table 17 for the dissolution of gibbsite in pure water at $25^{\circ} \mathrm{C}\left(77^{\circ} \mathrm{F}\right)$. A diagram, Figure 14 , can be constructed from the data In $_{\mathrm{Tab}} \mathrm{Te} 17$ to make a concentration $\mathrm{pH}$ diagram.

From this diagram it can be seen that the dissolution rate of gibbsite is minimal at a pH of about 5.8. Decreasing the $\mathrm{pH}$ from this value increases the concentration of $\mathrm{Al}^{3+}$; increasing the $\mathrm{pH}$ increases the concentration of $\mathrm{Al}(\mathrm{OH})_{4}{ }^{-}$. At pH 5.8 the $\mathrm{Al}^{3+}$ concentration is $0.01 \mu \mathrm{g} / 1$ and the $\mathrm{Al}(\mathrm{OH})_{4}{ }^{-}$ concentration is $0.017 \mu \mathrm{g} / 1$ as $\mathrm{Al}$. At neutral $\mathrm{pH}, \mathrm{Al}{ }^{3+}$ concentration is negligible $\left(2.7 \times 10^{-6}{ }_{\mu \mathrm{g} / 1}\right)$, and the $\mathrm{Al}(\mathrm{OH})_{4}^{-}$concentration is $0.27 \mu \mathrm{g} / 1$ 


\section{TABLE 16.}

Internal Surface Area and Volume, 1000-MW Fossil Plant Circulating Water System

Surface Area, $10^{6} \mathrm{dm}^{2}-$ Volume, $10^{6}$ iiters.

Surface Condenser

Dry Cooling Tower ${ }^{2}$

Piping $^{3}$

Total

$$
7.00
$$

8.93

1.76

17.69
4.02

5.13

$\underline{97.7}$

106.85

1- 80,000 tubes, $40^{\prime}$ long, 1" OD, 18 BWG

2- 102,000 tubes, 40' long, 1" OD, 18 BWG

3- 5260', 8' dia.; 1260', 7! dia; 1470!, 5! dia, 1000', 2' dia.

as A1. At the Preussag Power Plant at Ibbenburen, the circulating water is maintained at a pH of $\sim 7.8-8.0$, and they report an aluminum content of $20 \mu \mathrm{g} / 1^{(3)}$ : This agrees well with the theoretical amount, $15.85 \mu \mathrm{g} / 1 \mathrm{Al}(\mathrm{OH})_{4}^{-}$ (as. A1) at $\mathrm{pH} 8$, from the above considerations:

Thus the amount of dissolved aluminum corrosion product can be maintained at very low levels if the system pH is properly controlled, as shown in Figure 14. 
TABLE 17. Dissolution of Gibbsite in Pure Water, $25^{\circ} \mathrm{C}$

$\frac{1}{2} \mathrm{Al}_{2} \mathrm{O}_{3} \cdot 3 \mathrm{H}_{2} \mathrm{O}(\mathrm{s})=\mathrm{Al}^{3+}+30 \mathrm{H}^{-} . \quad \log \mathrm{K}=-34.0$

$\frac{1}{2} \mathrm{Al}_{2} \mathrm{O}_{3} \cdot 3 \mathrm{H}_{2} \mathrm{O}(\mathrm{s})+\mathrm{OH}^{-}=\mathrm{Al}(\mathrm{OH})_{4}^{-} \cdot \log \mathrm{K}=-1.0$

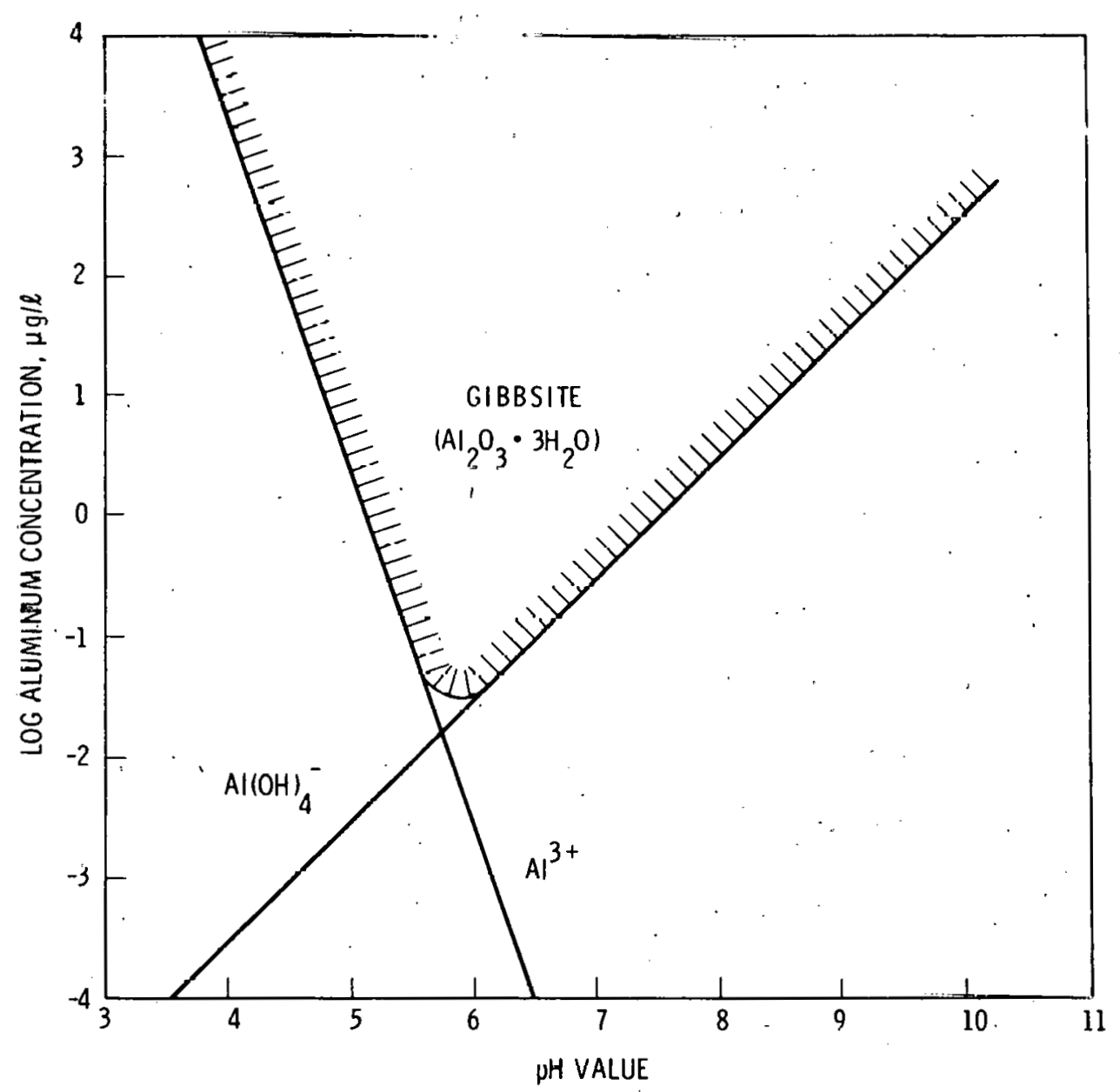

FIGURE 14. pH Dependence of the Solubility of Gibbsite. 


\subsubsection{Copper-Base Alloys}

\subsubsection{General Corrosion Behavior}

Copper-Base alloys are widely used in heat exchanger applications because of good corrosion resistance combined with mechanical workability, excellent thermal conductivity and ease of soldering or brazing. Examples of copper-base alloys commonly used in heat exchangers are given in Table 18. $(49,50)$

Alloys 142 and 443 perform well in fresh water once-through cooling systems when flow rates are below $2.1 \mathrm{~m} / \mathrm{sec}(7 \mathrm{fps})$; above this 1 imit they may be subject to inlet impingement attack. For severe operating conditions, alloys 608 or 706 are often used, although alloy 608 may be subject to pitting attack.

Admiralty (alloy 443) is commonly used as tubing material in jacket water aerial cooler applications. No performance-limiting corrosion of admiralty tubes in dry cooler usage has occurred in over 25 years of experience. However, as stated previously, the circulating water in jacket water dry coolers is chemically treated to inhibit corrosion. This mode of operation is potentially relevent to future dry cooling tower installations which utilize surface condensers ${ }^{(7)}$.. The experience in the dry coolers is not directly applicable to current technology, which involves corrosion by steam and steam condensate.

For salt and brackish water service, alloys $687,608,706$, or 715 frequently are chosen. Aluminum brass (alloy 687) is inhibited against dezincification, but high stresses and exposure to ammonia can lead to stress corrosion cracking. Recirculating systems serving evaporative cooling towers are generally constructed of alloy 443, although alloy 142 also. provides satisfactory service.

All the alloys mentioned provide good protection against exhaust steam or condensate corrosion of the tube external surface, but the best overall material is probably one of the copper nickel alloys. Reynolds and Pement state that of the copper-base alloys, 90/10 copper/nickel at 20 BWG $(0.035$ in), is the best standard engineering choice for a balance of physical, mechanical and 
TABLE 18. Copper Alloys l'sed for Tubular Heat Exchangers (50)

Nominal

Tube Material

Arsenical

Arsenic 0.35.

Phosphorus 0.03

\section{Advantãges}

(1) High thernal conductivity

2) Immune to stress corrosion cracking.

3) Good service experience in fresh water.

4) Excellent biofouling resistance.

i5) Has improved corrcsion resistance over copper.
(Alloy 194)

Copper

Iran

Phosphorus 0.03

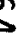

97.5
2.3
0.03

(1) Excellent corrosian resistance in fresh water.

(2) Immune to stress corrosion cracking

(3) Less costly than arsenical copper.

(4) Greater resistance to erosion corrosion than admiralty arid arsenical copper.

(5) Can be used cold worked.

(6) Excellent fouling resistance.

(7) High thermal conductivity.

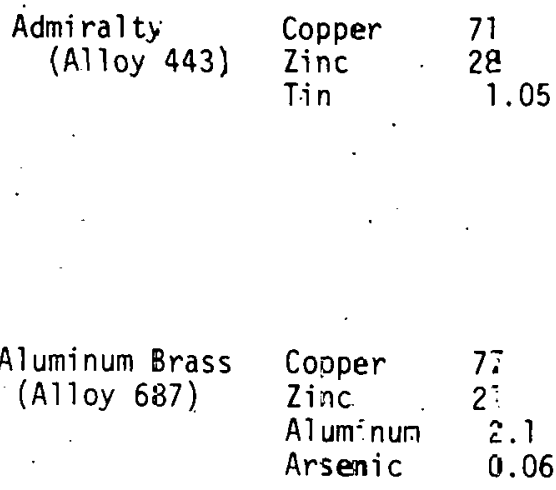

(1) Lowest cost of copper and copperbase alloys.

(2) Good waterside corrosion resistance in freshwater.

(3) Fair to good biofouling resistance.

(4) Improved resistance to suifidecontaining waters.

(5) Good thermal conductivity.

(1) Resistant to brackish and polluted waters.

(2) Moderate-in cost (>admiralty, <Cu/Ni).

(3) Resistant to sulfide-containing waters.

(4) More res stant than admiralty to dezinc:fication.

(5) rood thermal conductivity.

\section{0* sadvantages}

(1) High cost

2) Velocities $<1 \mathrm{~m} / \mathrm{sec}(3 \mathrm{fps})$ in seawater, $<2.1 \mathrm{~m} / \mathrm{sec}(7 \mathrm{fps}$ ) in fresh water.

(3) Susceftible to erosion corrosion and impingemen: attack.

(4) No prctective corrosion films other thar. copper oxides.

(5) Poor resistance to sulfide-containing waters.

(6) Very poor resistance to high ammonia concentrations in air removal sections.

(1) More costly than admiralty on equal-wall basis.

(2) Poor resistance to sulfide-containing waters.

(3) Poor saltwater corrosion resistance.

(4) Not resistant to high ammonia concentrations.

(1) Susceptible to stress corrosion cracking.

(2) Susceptible to dezincification.

(3) Freshuater velocity limit $1.8-2.4 \mathrm{~m} / \mathrm{sec}$ (6-3 fps); seawater. $1.5 \mathrm{~m} / \mathrm{sec}$ ( $5 \mathrm{fps})$.

(4) Susceptible to inlet end erosion corrosion.

5) Poor resistance to high ammonia concentrazions.

(6) Must je used annealed, therefore susceptible to handling damage.

(1) Susceptible to stress corrosion cracking

3) Prone to pitting in saline environments.

3) Susceptible to dezincification and dea Tuminumification.

4) Fair to poor bio-fouling resistance.

(5) Fair resistance to ammonia. 


\section{TABLE 18. (contd)}

\section{0/10 Copper/ Copper Nickel Nickel \\ (Alloy 706 ) \\ Iron}

요

70/30 Copper/ Copper Nickel Nicke
88.6
10

1.4 corrosion resistance.

(2) Immune to stress corrosion cracking.

(ङ) Good bio-fouling resistance.

(4) Resistant to pitting attack and erosion corrosion.

(5) Higher resistance to high velocities and local turbulent areas.

(6.) Excellent resistance to ammonia attack.

(i) May be used in light drawn condition.

(\&) Good physical and mechanical properties permit thinner wall.

$\begin{array}{ll}68.5 & \text { (1) Resistant to erosion corrosion. } \\ 31 & \text { (i) Immune to stress corrosion cracking. }\end{array}$

31

(Alloy 715 )

Iron

(1) Highest cost.

3) Can be used in cold worked condition. (3) Poor bio-fouling resistance.

(4) Best resistance to ammonia attack. (4) Low thermal conductivity.

(5) Strongest of copper-base condenser tube

(1) Costly (may be offset by thinner wall).

(2) Fair thermal conductivity.

(3) Not fully resistant to waters containing sulfide. alloys: 
corrosion properties vs cost ${ }^{(51)}$. ' It should out-perform the 18 BWG (0.049 in) brass alloys in almost all cases. 70/30 copper nickel is also excellent from a corrosion resistance standpoint; it is practically immune to stress corrosion cracking in ammonia and has good resistance to pitting attack, especially at water velocities exceeding $1.67 \mathrm{~m} / \mathrm{sec}(5.5 \mathrm{fps})$. Based on good corrosion resistance, $70 / 30$ copper/nickel is usually employed in the air-cooler section of surface condensers.

Hager $(50)$ points out that proper alloy choice rather than thicker tube wall builds reliability into a condenser tube. Tube failure generally occurs by highly selective attack; added wall thickness will. forestall the failure for a short period, but proper alloy selection will prevent it. Alloy 706 (90/10 copper/nickel) is often recommended because increased corrosion resistance permits thinner tube walls.

In general, the condenser tube alloys in common use owe their good corrosion performance to special additions which promote the formation of a protective film ${ }^{(52)}$. The film is easily disturbed by high-velocity water or may be dissolved by species such as carbonic acid and ammonium hydroxide.

\subsubsection{Effect of $\mathrm{pH}$}

General attack of copper-base condenser tubing is lowest in the $\mathrm{pH}$ range of 6 to 12, with the $\mathrm{pH}$ of minimum corrosion being about 9.4. A curve showing the general relation between $\mathrm{pH}$ and the corrosion behavior of copper alloys is presented in Figure $15{ }^{(52)}$. Also, see Figure 21.

When excessive amounts of carbon dioxide and oxygen buildup in condensers and dissolve in the condensate, the $\mathrm{pH}$ drops and corrosion grooving may occur. This type of corrosion is most pronounced at baffles and tube sheets where the acidic condensate collects.

When ammonia is not adequately vented, steam condensate becomes very corrosive to copper alloy condenser tubing. Water containing ammonium ions will prevent the formation of protective films on the metal surface. Condensate in the air cooler section may contain as much as 500 ppm ammonia which will cause rapid local corrosion of the tubing ${ }^{(52)}$. 


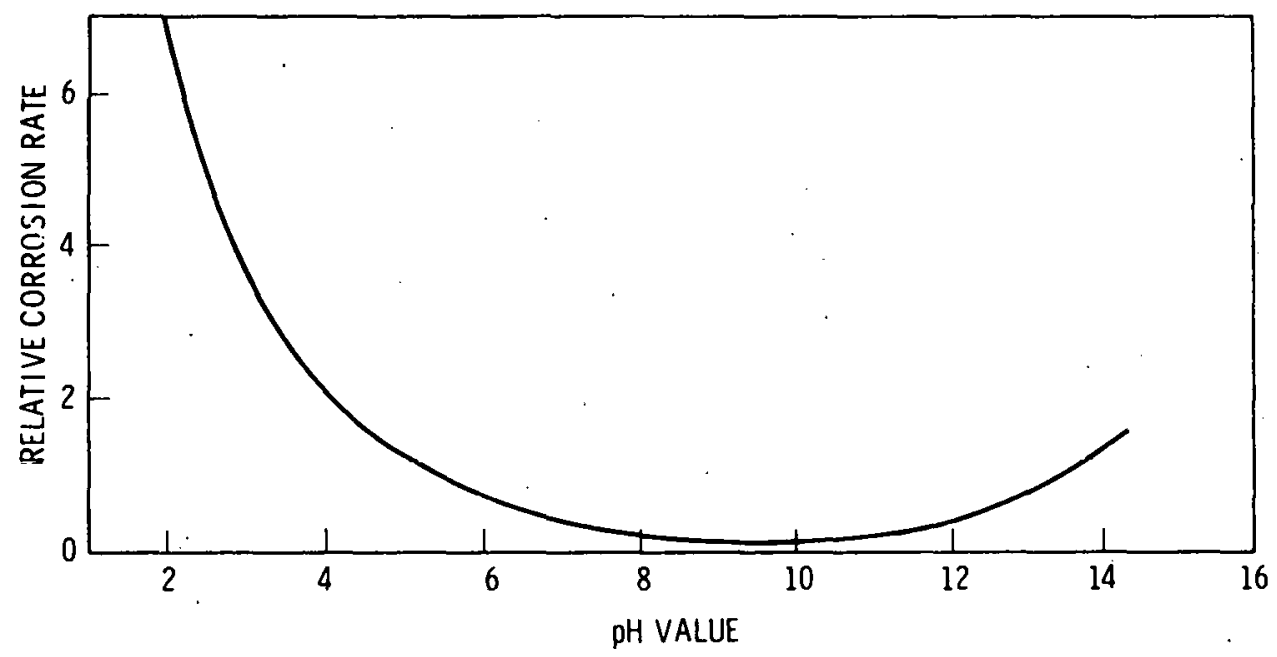

FIGURE 15. Relative Effect of pH on the Rate
of Corrosion of Copper Alloys $(52)$

The problem has largely been eliminated in newer two-pass condensers which have been redesigned to eliminate horizontal baffles, below which the vapor phase becomes rich in ammonia. Improved longitudinal control of the venting system has also alleviated this problem.

\subsubsection{Corrosion Mechanisms}

\section{Stress Corrosion Cracking}

Nearty aाt copper alloys are subject to stress corrosion cracking ${ }^{(53)}$; commercial tough pitch and electrolytically refined copper are generally immune $^{(32)}$. Stress corrosion cracks in most copper alloys are usually intergranular, but this is not always so and cannot be used to differentiate this type of cracking from other types such as fatigue cracking. Admiralty and aluminum brass almost invariably crack transgranularly.

Four factors that promote stress corrosion cracking are tensile stress, corrodent, susceptibility of the metal, and time ${ }^{(54)}$. Either residual or applied stress can induce stress corrosion cracking. Residual or internal stresses are those resulting from some prior deformation such as deep drawing or spinning(53). Applied or external stresses generally are controllable if properly addressed in the equipment design. Either type of 
stress may cause stress corrosion cracking, but only if the stress is tensile. Compressive stresses do not cause stress corrosion cracking; surface compressive stresses actually tend to prevent it, even though tensile stresses may exist in the body of the metal ${ }^{(55)}$.

The most important corrodent responsible for the cracking of copperbase alloys is ammonia $\left(\mathrm{NH}_{3}\right)^{(54)}$. Aqueous ammonia solutions are unique because they do not cause cracking in any other metal system. Amines and sulfamic acid also cause cracking. The presence of oxygen or other oxidizing agents (including carbon dioxide) is also necessary. The controlling factor may be moisture; stress corrosion cracking of brass dues not occur in dry ammonia ${ }^{(5,3)}$.

According to Thompson $(53,55)$, copper alloys can be roughly classified according to their resistance to stress corrosion cracking as follows:

Low resistance --

- Brass containing over $20 \%$ zinc

- Brass containing over $20 \%$ zinc and small amounts of lead, tin or aluminum

Intermediate resistance --

- Brass containing less than 20\% zinc

- Nickel silver:

- Phosphor bronze

High resistance --

- Silicun brunze

- Phosphorized copper

Very high resistance --

- Copper nickel

- Tough-pitch copper

- Aluminum bronze 
Using Thompson's experience as a guide, the CDA alloy numbers, in order of increasing resistance to ammonia stress corrosion cracking, would be $443,687,608,706,715,194$, and 122 .

Brunn and Schmidt indicate that the stress corrosion cracking tendency of aluminum brass (alloy 687) reaches a maximum at an arsenic content of about $0.08 \%(56)$. Other workers ${ }^{(57)}$ have shown that additions of $1.0-1.5 \%$ silicon to aluminum brass considerably reduce the stress corrosion susceptibility without affecting the corrosion resistance or physical or mechanical properties.

The fourth factor involved in stress corrosion cracking, the one which is a measure of resistance, is time. Cracking may occur in as little as five minutes or it may be delayed for months or years. Specimens have cracked after exposures of ten years in controlled tests ${ }^{(54)}$.

Condenser and heat exchanger tubes are subject to some, but usually not all, of the factors that contribute to stress corrosion cracking. Tubes are often admiralty or aluminum brass, alloys highly susceptible to stress corrosion cracking. Ammonia and amines are present in the steam and condensate from boiler feedwater additives to raise the $\mathrm{pH}$ and reduce corrosion of iron-base alloys in the thermal cycle. The low incidence of stress corrosion cracking in condensers and heat exchangers is due to the fact that air concentrations tend to be low in the cooling space, except in the air removal sections of the condenser. Also, residual stress generally is low because the tubes are supplied in the annealed condition. Annealing is the most effective means of removing residual stresses to suppress stress corrosion cracking (5:3). For $30 \% \mathrm{Zn}-\mathrm{Cu}$ brass (i.e., admiralty), heating at $350^{\circ} \mathrm{C}\left(662^{\circ} \mathrm{F}\right)$ for one hour is effective but recystallization and some loss of alioy strength will result ${ }^{(32)}$. Heat treatment at $300^{\circ} \mathrm{C}$ $\left(572^{\circ} \mathrm{F}\right)$ reportedly improves resistance to cracking without serious loss of physical properties. If contact with ammonia or oxygen can be avoided, cracking tendencies will be greatly minimized. However, it is difficult to guarantee that there will be no contact with ammonia because ammonia and amines are commonly used for oxygen and $\mathrm{pH}$ control, and very small 
quantities of ammonia cause cracking. 0xygen removal is less difficult; brass condenser tubes do not frequently crack in boiler water condensate containing ammonia because oxygen concentrations are extremely low.

Intergranular Attack

Aluminum bronzes are less frequently chosen for heat exchanger service than some of the other copper base alloys; alloy 614 is subject to stress-accelerated intergranular attack in steam atmosphieres.

Brass alloys, such as admiralty, have a relatively high susceptibility to intergranular corrosion. Some investigators believe that high arsenic and phosphorus levels in inhibited admiralty lead to intergranular attack (37).

\section{Crevice Corrosion}

Unlike the film-forming metals, such as stainless steels and aluminum, where crevice attack occurs deep in the interior of the crevice, the attack on copper alloys occurs at or near the mouth of the crevice. Instead of a differential aeration mechanism, a copper-ion concentration cell develops, with the highest concentration of copper ions within the crevice. Numerous examples have been observed on marine exposures; the problem is not expected on high-purity water systems. (37)

\section{Pitting Corrosion}

Pitting of copper-base alloys is usually caused by differential aeration cells, which are set up beheath deposits on the cupper surface, or by local high-velocity conditions. Pitting can normally be avoided by keeping the surfaces clean and by avoiding velocities, design geometries, and surface asperities which lead to ernsion at.tar.k (32). In steam condensate and high purity water, pitting corrosion of copper alloys should not be a problem.

\section{Dezincification}

Dezincification occurs in copper alloys either by preferential zinc corrosion or by simultaneous dissolution of copper and zinc with subsequent redeposition of copper. Whatever the mechanism, a porous residue of copper and corrosion products is left. The alloys so corroded often retain their 
original shape, but their tensile strength and ductility are seriously reduced ${ }^{(32)}$. This type of attack has been observed most frequently in uninhibited brass condenser tubing ${ }^{(52)}$. Dezincification of all alpha brasses with up to $40 \%$ zinc can be reduced by alloying additions of about $1 \%$ tin or a few hundredths percent arsenic, phosphorus, or antimony. In normal power plant operation, the addition of arsenic (0.02-0.10\%) to admiralty brass is usually effective in preventing this type of attack.

Exposure conditions which favor dezincification are (1) elevated temperatures, (2) stagnant solutions, and (3) porous inorganic scale formation. With proper alloy selection dezincification can be eliminated under dry cooling tower conditions.

\section{Fretting Attack}

Fretting corrosion is defined as damage occurring at the interface of two contacting surfaces, one or both being metal, subject to slight, high frequency relative slip. In the extreme, such damage may lead to failure by metal penetration, fatigue, or corrosion fatigue. At sufficiently high loads, soft metals serve to exclude air at the interface. Also, a soft metal may yield by shearing instead of sliding at the interface, thereby reducing damage. For this reason, brass in contact with steel tends to be less damaging than steel versus steel ${ }^{(32)}$.

Damage due to fretting can be minimized by combinations of soft metals with hard mctals as described above, design ot contacting surfaces to eliminate slip, and use of gaskets or lubricants.

\section{Corrosion Fatigue}

Cracking of a metal resulting from the combined action of a corrosive enviromiment and repeated or alternate stress is known as corrosion fatigue. The damage is almost always greater than the sum of the damage by corrosion and fatigue acting separately (32).

Corrosion fatigue cracks are typically transgranular. They are often branched, and several cracks are usually observed at the metal surface in the vicinity of the major crack diccounting for the failure. 
Metallographic examination of corrosion fatigue cracking of heatexchanger tubing made of aluminum brass showed that local pitting corrosion led to the formation of fatigue cracks ${ }^{(58)}$. Intergranular pitting attack followed by transgranular fatigue cracking has also been observed in admiralty brass tubing. However, pitting is not a necessary precursor to failure.

In heat. exchanger service, corrosion fatigue failures occur most frequently with the brasses. Copper nickel alloys, which tend to withstand corrosion better than the brasses, are more resistant to corrosion fatiguc. In general, resistance nf a metal to corrosion fatigue is associated more nearly with its inherent corrosion resistance than with high mechanical strength ${ }^{(32)}$.

Corrosion fatigue failures occur infrequently in heat exchangers; nevertheless, all types of tubular materials can fail in this manner under certain conditions. Tubes with high stress levels at the surface are most susceptible. Copper alloys are frequently supplied in a cold worked condition, resulting in residual stress. Stress may also bc induced during tube manufacture, shipping installation, and by faulty maintenance. When susceptible tubes are subject to violent vibration, fatigue cracks may develop. Vibration has been experienced in steam condensers when the tube supports are too widely spaced, resulting in severe resonant vibrations. It is characteristic to find the crack location approximately midway between tube supports. Sometimes fatigue cracks occur at or near the tube sheet or tube support. (37)

Vibration in existing condensers can be controlled by eliminating the source or by making alterations to the condenser itself. Vibration also can be alleviated by applying Micarta tube supports at intermediate points along the tubing.

The selection of support spacing for tubing in new condensers can be guided by service experience with units which are free from this difficulty even though they are surrounded by sources of vibration. Calculational methods also can be applied to define the optimum location of the supports ${ }^{(28)}$. 
Fretting attack on vibrating tubes where they contact tube supports may set up fatigue cracks. Experimental evidence has been developed in a twostage test to show the role of fretting on fatigue. First, a material is subjected to a fretting fatigue test for a number of cycles. If a fatigue crack is initiated it will propagate to failure in the second stage without fretting. The typical number of fretting cycles to initiate a crack, under the conditions of the experiment, was found to be 30,000 for steels, 100,000 for age-hardened aluminum alloys, and 350,000 for copper alloys.

\section{Erosion Corrosion}

Copper has shown sensitivity to corrosion by high-velocity water, particularly at inlet ends of heat exchanger and condenser tubes ${ }^{(59)}$. The corrosion rate increases with dissolved oxygen and chloride ion concentration and with low $\mathrm{pH}^{(32)}$. Copper-zinc alloys are more resistant to impingement attack than copper and hence are used in preference to copper for condenser tubes. Table 19 summarizes the resistance of various copper alloys to impingement attack by showing the maximum allowable water velocities for each alloy in heat exchanger service.

An excellent summary of the effect of velocity and temperature on the impingment attack of copper, admiralty and $90 / 10$ copper nickel has been published by Myers and Obrecht ${ }^{(60)}$. Fiqures 16 and 17 show the results with regard to copper, CDA alloy 122.

These curves show that for relatively non-aggressive deaerated waters, velocities in copper tube systems should not exceed $2.4 \mathrm{~m} / \mathrm{sec}$ ( $8 \mathrm{fps}$ ) and temperatures should not exceed $60^{\circ} \mathrm{C}\left(140^{\circ} \mathrm{F}\right)$. Where aggressive waters (high purity waters with appreciable quantities of oxygen and carbon dioxide) are involved, the velocity in a copper tube system should not exceed $1.2 \mathrm{~m} / \mathrm{sec}(4 \mathrm{fps})$. Even at that velocity, maximum penetration was about $4.5 \mathrm{mpy}$ at $60^{\circ} \mathrm{C}\left(140^{\circ} \mathrm{F}\right)$.

Figure 18 shows the rates of impingement attack of admiralty brass at various temperatures and velocities. 
TABLE 19.

MAXIMUM ALLOWABLE VELOCITIES OF AERATED FRESH WATER FOR COPPER ALLOYS IN HEAT EXCHANGER SERVICE

\begin{tabular}{llcc} 
Alloy & \multicolumn{1}{c}{ Common Name } & Velocity, $\mathrm{m} / \mathrm{sec}$ & (fps) \\
\cline { 1 - 1 } 122 & Deoxidized Copper & $1.2-1.5$ & $4-5$ \\
194 & HSM Copper & 1.5 & 5 \\
443 & Admiralty & 2.4 & 8 \\
608 & Aluminum Bronze & 2.7 & $y$ \\
614 & Aluminum Bronze $+2 \mathrm{Fe}$ & 3.4 & 11 \\
687 & Aluminum Brass & 3.4 & 11 \\
706 & $90 / 10$ Copper/Nickel & 3.6 & 12 \\
715 & $70 / 30$ Copper/Nickel & 4.6 & 15
\end{tabular}
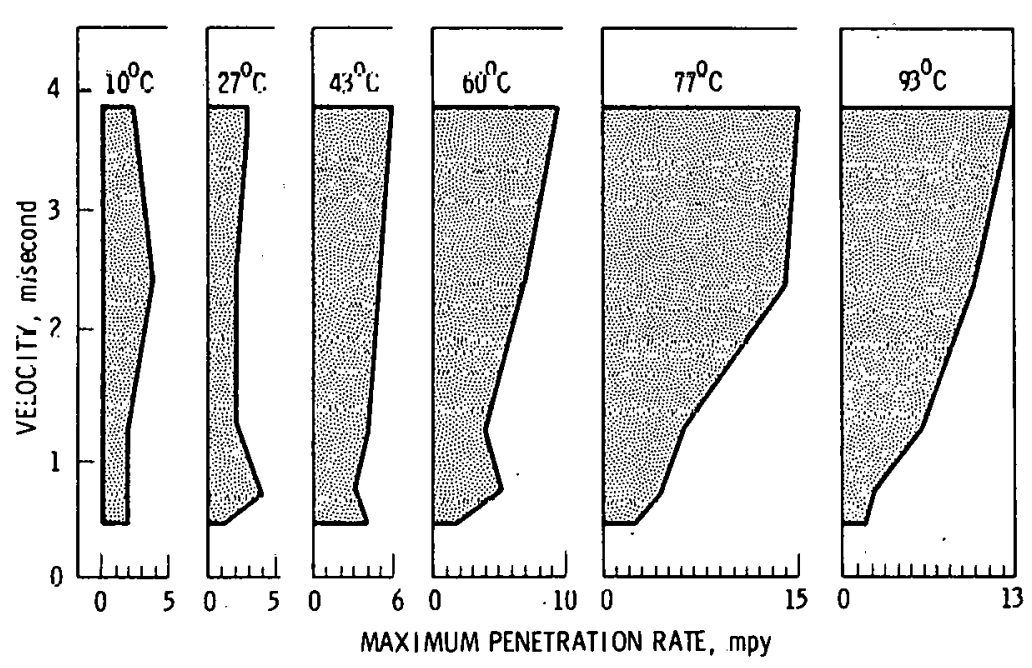

FIGIJRE 16. Effect of Velocity on the Maximum Erosion Corrosion Penetration Rate for Copper Tube Exposed to Sodium Zeolite Softened, Aerated Water at Selected Temperatures (60). 

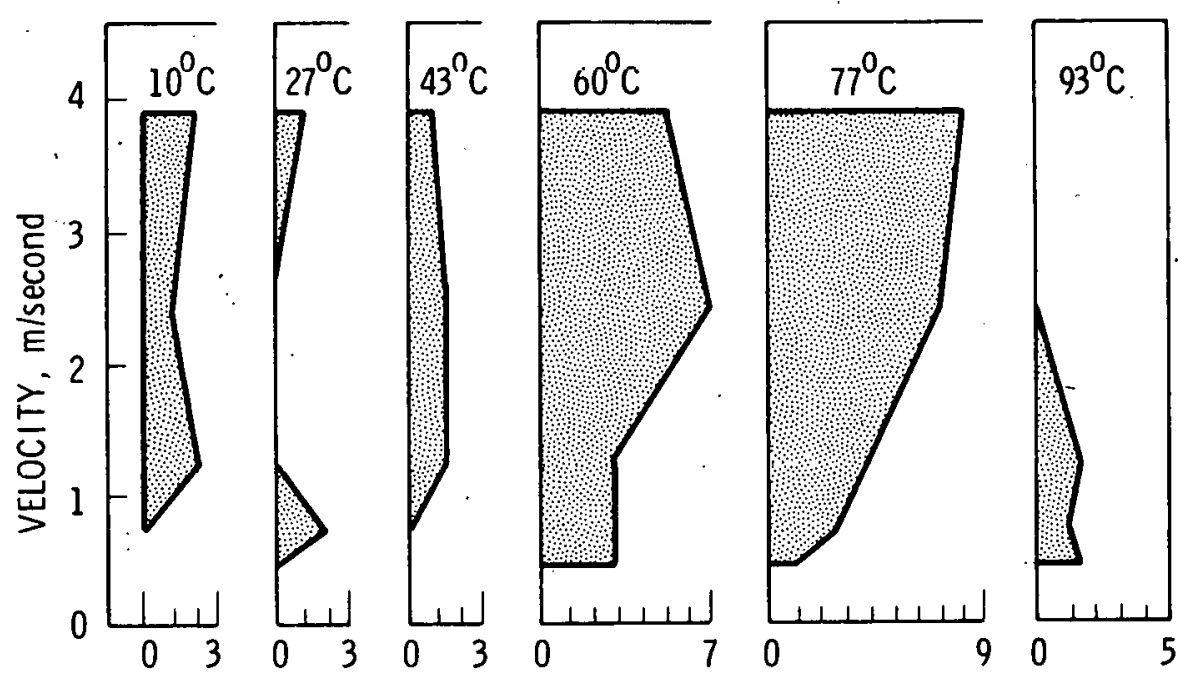

MAXIMUM PENETRATION RATE, mPY

FIGURE 17. Effect of Velocity on the Maximum Erosion Corrosion Penetration Rate for Copper Tube Exposed to Sodium Zeolite Softened, Cold Vacuum Deaerated Water at Selected Temperatures (60).
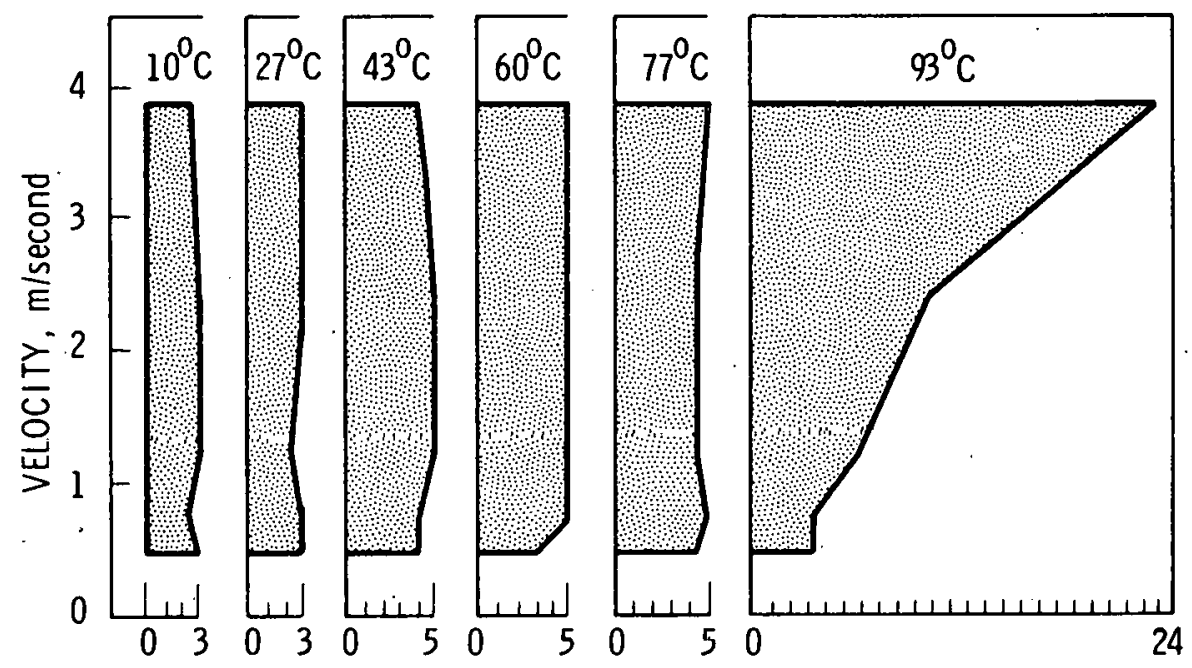

MAXIMUM PENETRATION RATE, mPY

FIGURE 18. Effect of Velocity on the Maximum Erosion Corrosion Penetration Rate for Admiralty Brass Tube Exposed to Sodium Zeolite Softened, Aerated Water at Selected Temperatures (60). 
These figures show that admiralty brass tubing has good resistance to impingement attack by high purity water containing appreciable quantities of dissolved oxygen and carbon dioxide at velocities up to $4.0 \mathrm{~m} / \mathrm{sec}(13.1 \mathrm{fps})$, provided that the temperature does not exceed $77^{\circ} \mathrm{C}\left(170^{\circ} \mathrm{F}\right)$.. The maximum penetration rate under these conditions. is about $5 \mathrm{mpy}$.

Figure 19 shows results of similar tests for 90/10 copper nickel.
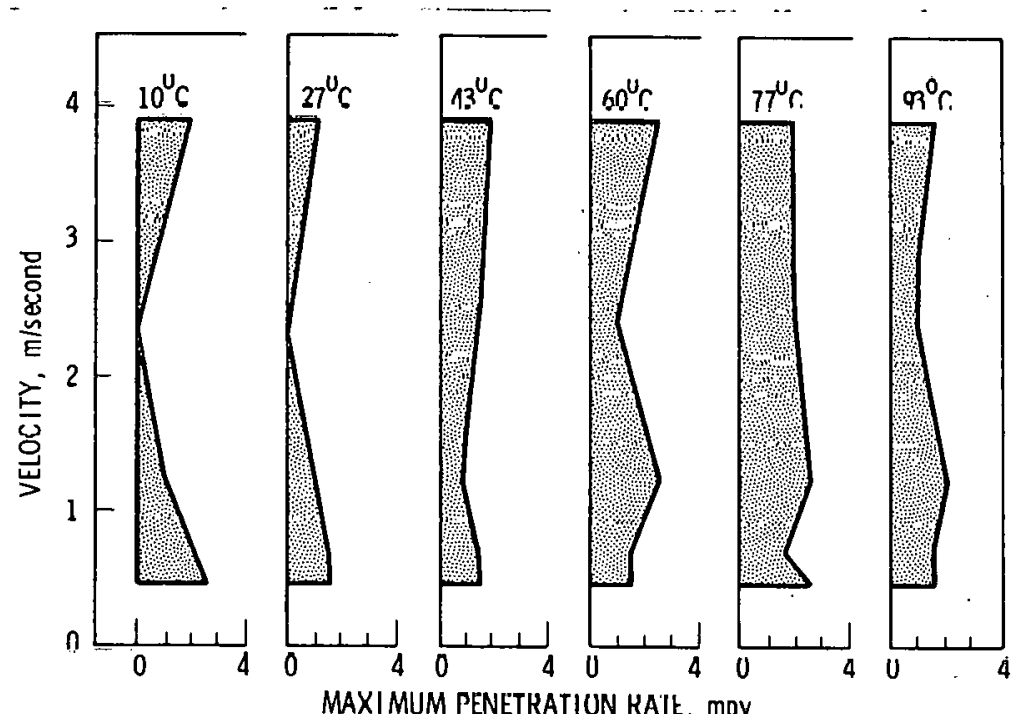

FIGURE. 19. Effect of Velocity on the Maximum Erosion Corrosion Penetratiun Rale for 90/10 Copper Nickel Exposed to Sodium 7eolite Softened, Aerated Water at Selected Temperatures (60).

of the metals tested, this alloy had by far the greatest resistance to impingement attack. Maximum penetration was less than 2 mpy at velocities up to $4.0 \mathrm{~m} / \mathrm{sec}(13.1 \mathrm{fps})$ and temperatures up to $93^{\circ} \mathrm{C}\left(200^{\circ} \mathrm{F}\right)$; however, even this amount of corrosion may be unacceptable in nuclear systems from the standpoint of corrosion product transport.

$\underline{\text { Galvanic Attack }}$

Copper is noble to both aluminum and iron, as has been mentioned previously. It may cause serious corrosion of these metals when coupled to them. 
Again, there will always be some pickup of copper ions from any of the copper-base heat exchanger alloys by high-purity water or steam condensate. The copper ions may be transported to other parts of the system where they will plate out on more active metals such as steel or aluminum. Local pitting of these metals may develop as a result of the galvanic action resulting from the copper ion contamination.

\section{Corrosion Product Transport}

Release rates of corrosion products from copper alloys into high purity, neutral $\mathrm{pH}$ water systems at two oxygen levels and various temperatures are shown in Table 20. (24) These data are from tests using continuously demineralized test water. The release rates at both oxygen levels are about equal to their respective corrosion rates. The corrosion and release rates for the copper-base alloys are significantly increased by oxygen addition to neutral, continuously-purified water. Corrosion rates increased from between one and ten $\mathrm{mg} / \mathrm{dm}^{2} / \mathrm{mo}$ at $10 \mathrm{w}$ temperatures and oxygen concentrations to around $1000 \mathrm{mg} / \mathrm{dm}^{2} / \mathrm{mo}$ at high temperatures and oxygen levels.

These data indicate that oxygen concentrations in refreshed systems using copper-base alloys should be maintained as low as possible to minimize corrosion and corrosion product dissolution.

In discussion of a paper by Johnson and Kehmna $(61), W$. A. Keilbaugh points out that boiler feedwater corrosion product contamination is transported on both soluble and insoluble forms. Deposition can result directly from the insoluble corrosion product without a transition through. some soluble state. Thus it is important to minimize overall corrosion as well as corrosion product dissolution; the findings of Brush and Pearl $(24,62)$ are therefore pertinent in a qualitative way to closed, nonrefreshed circulating systems.

In closed circulating water systems, corrosion product dissolution will increase to an equilibrium value; soluble copper concentration will 
TABLE 20. Corrosion Product Release from Copper Alloys(22)

\begin{tabular}{|c|c|c|c|}
\hline Material & Temp. $\left({ }^{\circ} \mathrm{C}\right)$ & $\begin{array}{c}\text { Release } R \\
3 \mu \mathrm{g} / 1 \text { Oxygen } 5 \\
100-200 \text { Hydrogen } \\
(\mu \mathrm{g} / 1) \\
\end{array}$ & $\begin{array}{c}\text { ate, } \mathrm{mg} / \mathrm{dm}^{2} / \mathrm{mo} \\
200 \mathrm{\mu g} / 1 \text { Oxygen } \\
25 \text { Hydrogen } \\
(\mu \mathrm{g} / \mathrm{l}) \\
\end{array}$ \\
\hline \multirow[t]{7}{*}{70 Copper + 30 Nickel } & 38 & & 17.8 \\
\hline & 66 & 2.7 & 43.3 \\
\hline & 93 & 3.1 & 12.9 .0 \\
\hline & 121 & 2.5 & 7.0 \\
\hline & 149 & 3.2 & 495.0 \\
\hline & 177 & 5.9 & 2738.0 \\
\hline & 204 & 11.3 & 747.0 \\
\hline \multirow[t]{7}{*}{70 Copper + 30 Nicke $1+$ Iron } & 38 & & 0.9 \\
\hline & 66 & 1.8 & 12.6 \\
\hline & 93 & 2.0 & 42.5 \\
\hline & 121 & 2.2 & 50.3 \\
\hline & 149 & 2.4 & 621.0 \\
\hline & 177 & 3.2 & 786.0 \\
\hline & 204 & 7.1 & 666.0 \\
\hline \multirow[t]{7}{*}{90 Copper + 10 Nickel } & 38 & & 14.4 \\
\hline & 66 & 0.5 & 71.4 \\
\hline & 93 & 1.4 & 118.0 \\
\hline & 121 & 1.0 & $107.0^{\circ}$ \\
\hline & 119 & 1.3 & 136.0 \\
\hline & 177 & 2.9 & 276.0 \\
\hline & 204 & 7.1 & 1554.0 \\
\hline \multirow[t]{7}{*}{ Admiralty Brass } & 38 & & 21.7 \\
\hline & 66 & 1.3 & 98.1 \\
\hline & 9.3 & 1.3 & 365.0 \\
\hline & 121 & 2.5 & 969.0 \\
\hline & 149 & 4.6 & \\
\hline & $177^{\circ}$ & 3.7 & \\
\hline & 204 & 7.2 & \\
\hline
\end{tabular}


then remain constant. In static tests using unrefreshed deionized water at. 38 and $43^{\circ} \mathrm{C}\left(100\right.$ and $\left.109^{\circ} \mathrm{F}\right)$, Johnson ${ }^{(63)}$ found that copper corrosion product dissolution leveled off after about 30 days to give a total dissolution of about $0.37 \mathrm{mg} / \mathrm{cm}^{2}(1.2 \mathrm{mg} / 1)$. The data are shown graphically in Figure 20. The pH of the water used in these tests was not specified, but neutrality is assumed.

The shape of these curves indicates either that a protective film develops, thereby hindering further dissolution, or that saturation occurs. Physical examination of the specimens revealed an adherent oxide film, which is characteristic of protective oxide formation ${ }^{(63)}$.

Concerning the solubility of the copper corrosion products, the following reactions are pertinent $(48,61)$ :

$$
\begin{array}{ll}
\mathrm{Cu}(\mathrm{OH})_{2}+2 \mathrm{H}^{+}=\mathrm{Cu}^{++}+2 \mathrm{H}_{2} \mathrm{O} & \text { Log K }=9.2 \\
\mathrm{Cu}(\mathrm{OH})_{2}=\mathrm{HCuO}_{2}^{-}+\mathrm{H}^{+} & \text {Log } \mathrm{K}=17.6
\end{array}
$$

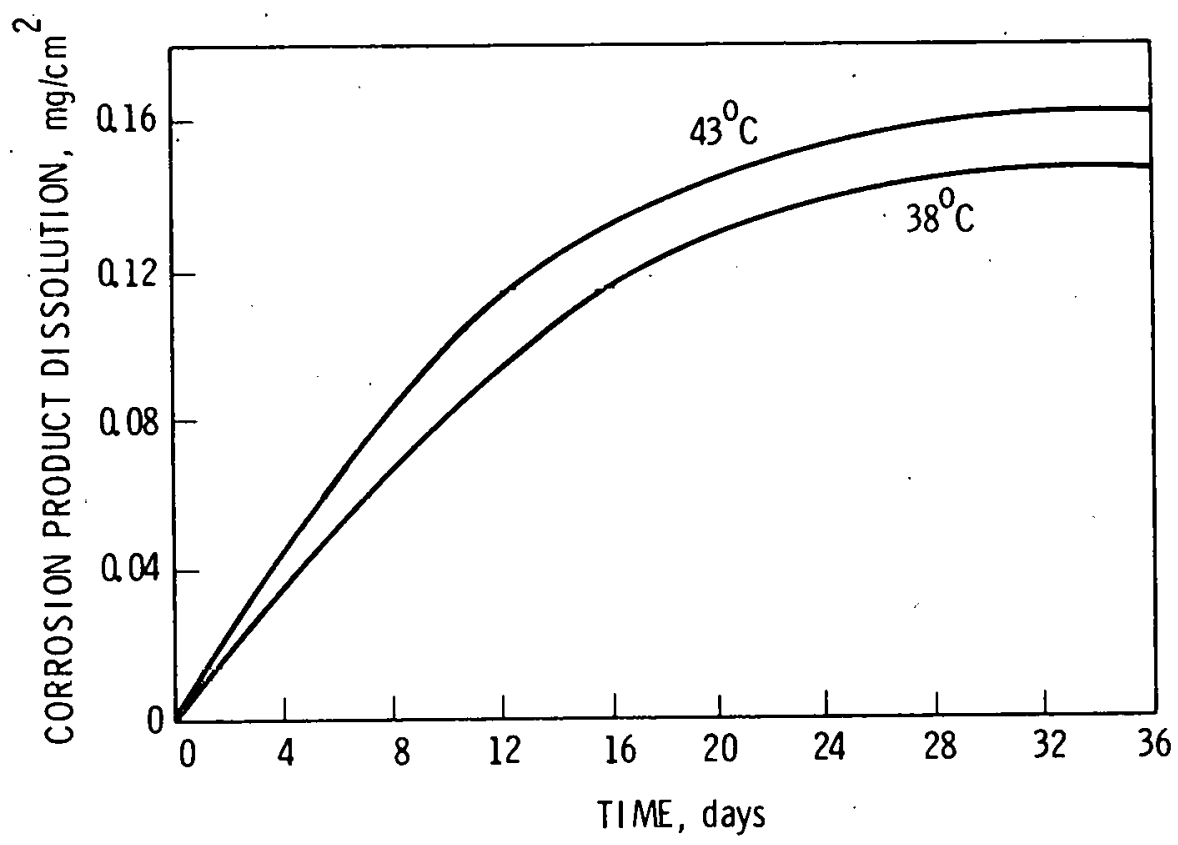

FIGIIRE 20. Release of Copper Corrosion Product to Static, Unrefreshed Deionized Water (63). 


$$
\begin{array}{ll}
\mathrm{Cu}(\mathrm{OH})_{2}=\mathrm{CuO}_{2}^{--}+2 \mathrm{H}^{+} & \text {Log } \mathrm{K}=30.6 \\
\mathrm{Cu}^{++}+\mathrm{OH}^{-}=\mathrm{CuOH}^{+} & \text {Log } \mathrm{K}=6.0 \\
\mathrm{Cu}^{++}+3 \mathrm{OH}^{-}=\mathrm{Cu}(\mathrm{OH})_{3}^{-} & \text {Log K}=15.2
\end{array}
$$

From these data the roncentration-pH diagram in Figure 21 can be constructed.

This diagram shows that the dissolution of copper hydroxide (hydrated copper oxide) reaches a minimum at about $\mathrm{pH} 9$. At this $\mathrm{pH}$ the tulal dissolved copper concentration is about $0.5 \mu \mathrm{g} / 1$, the major dissolved species being $\mathrm{Cu}^{++}$and $\mathrm{HCuO}_{2}^{-}$. Dissolved copper concentration increased at $\mathrm{pH}$ values greater than or less than 9; at $\mathrm{pH} 10$ the copper concentration is about $1.6 \mu \mathrm{g} / 1$ and at $\mathrm{pH} 7$ it is about $1 \mu \mathrm{g} / 1$, which agrees well with the experimental data of Johnson ${ }^{(63)}$.

As with aluminum alloys, the total dissolved copper in the circulating water of a 1000 MWe fossil plant will be very low if the $\mathrm{pH}$ is carefully controlled. However, deposition can occur if an appropriate sink is available, since the concentration of bivalent cupper is not strictly limited; any mechanism which removes one of the bivalent copper species in the above reactions will result in increased $\mathrm{Cu}(\mathrm{OH})_{2}$ dissolution. Johnson and Kehmna ${ }^{(61)}$ point out that if the atomic ratio of bivalent copper to bivalent iron contamination is greater than 0.5 , essentially all of the iron will be oxidized to $\mathrm{Fe}(\mathrm{OH})_{2}{ }^{+}$and ullillialely to $\mathrm{Fe}(\mathrm{OII})_{3}$ solid phasc. Bivalent copper is reduced to metallic copper in this reaction. The $\mathrm{Cu}^{++} / \mathrm{Fe}^{++}$ratio is greater than 0.5 at. $\mathrm{pH}$ values above 11 (see Figure 28); in this range deposits of ferric oxides and metallic copper can be expected. 


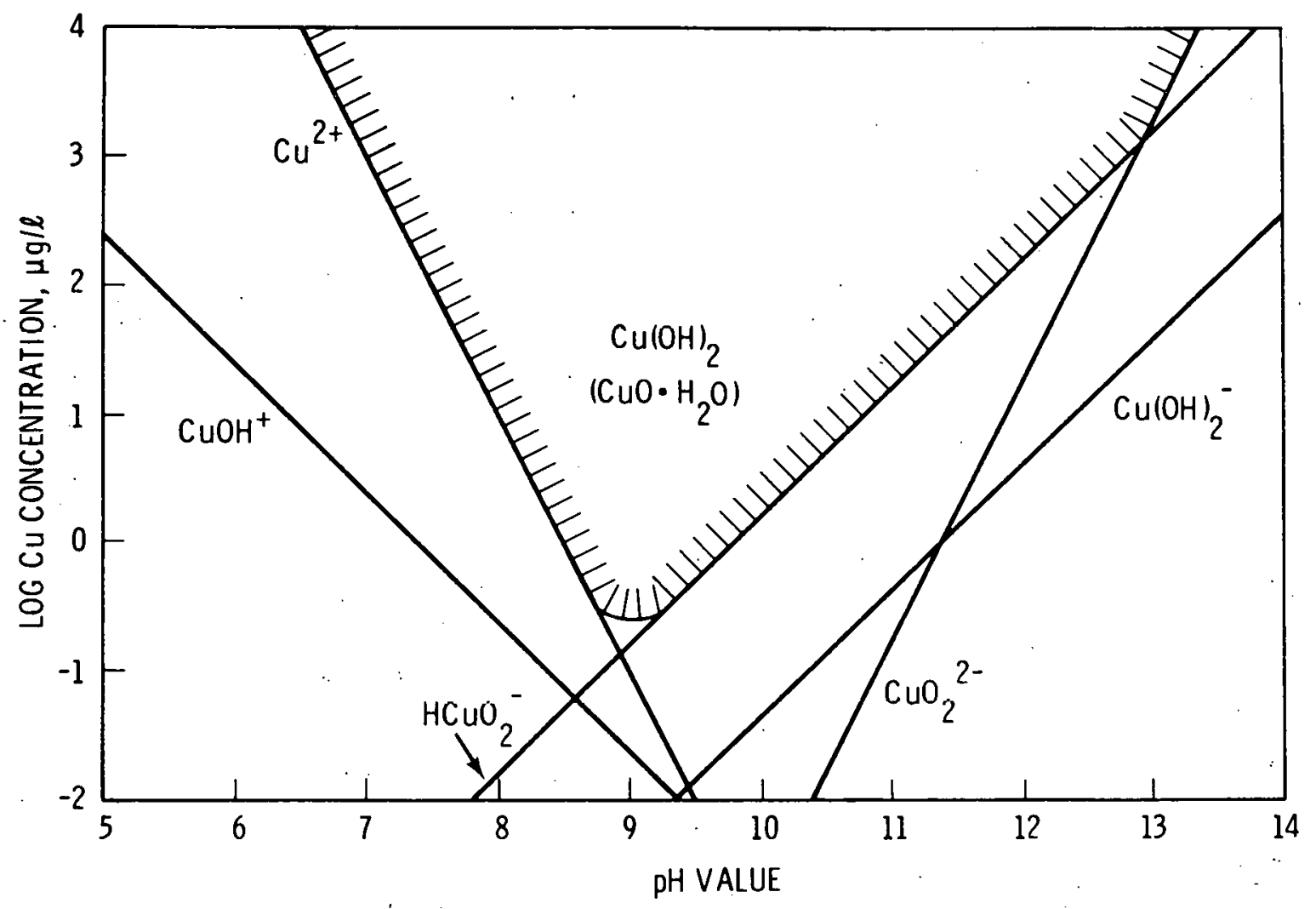

FIGURE 21. pH Dependence of the Solubility of Hydrated Copper Oxide 


\subsubsection{Iron-Base Alloys}

The stainless steels, particularly alloys 304 and 316 , are used increasingly as condenser material; they presently have broad acceptance as feedwater heater material. It is projected that by 1985 stainless steel will account for approximately one-quarter of the conventional surface condenser material market, with copper-base alloys accounting for one-half and titanium about one-quarter of the market ${ }^{(28)}$. Carbon steel is used for piping and condenser shells in indirect dry cooling systems and for. piping and dry tower tubing in direct systems. Carbon steel căn be considered a candidate for dry cooling tower components and piping in the closed recirculating system employing a surtace condenser if proper control of water chemistry is maintained. Stainless steel is used for spray nozzles in the condenser of direct systems.

Hager $(50)$ gives the following advantages and disadvantages for stainless steel as a condenser material:

Advantages -

1) Excellent condensate-side corrosion resistance

2) Lower cost on a per-foot bas is compared with heavier wall copper allnys

3) Negligible general corrosion rate

4) Physical and mechanical properties permit thin walls $(0.7 \mathrm{~mm})$

5) Resistant to velocities in excess of $4.6 \mathrm{~m} / \mathrm{sec}(15 \mathrm{ft} / \mathrm{sec})$

Disadvantages -

1) Susceptible to selective attack

2) Must be kept. c.lcan to assure condenser tube reliability

3) Highly susceptible to chloride attack (pitting)

4) Very low thermal conductivity

\subsubsection{General Corrosion Behavior}

At anodic areas, iron corrodes according to the reaction

$$
\mathrm{Fe}=\mathrm{Fe}^{++}+2 \mathrm{e}^{-} \text {. }
$$


This reaction is rapid in most media; the overall iron corrosion rate is controlled by the slower cathodic reaction, one of which is:

$$
\mathrm{H}^{+}+\mathrm{e}^{-}=1 / 2 \cdot \mathrm{H}_{2} \text {. }
$$

This reaction proceeds rapidly at low pH but only slowly in neutral or alkaline aqueous media. For example, in deaerated neutral water at room temperature, the corrosion rate of iron is less than $1 \mathrm{mg} / \mathrm{dm}^{2} / \mathrm{day}$.

An important cathodic reaction in aqueous solutions above $\mathrm{pH} 4$ containing oxygen is:

$$
\mathrm{H}_{2}+1 / 2 \mathrm{O}_{2}=\mathrm{H}_{2} \mathrm{O}
$$

This reaction can proceed only as rapidly as oxygen reaches the metal surface; thus the rate of iron corrosion is controlled by the diffusion rate of oxygen to the surface of the metal. The overall corrosion reaction of iron, found by combining this reaction and the anodic reaction for the corrosion of iron, is: (31)

$$
\mathrm{Fe}+\mathrm{H}_{2} \mathrm{O}+1 / 2 \mathrm{O}_{2}=\mathrm{Fe}(\mathrm{OH})_{2}
$$

In order to minimize iron dissolution in condensate and feedwater lines in modern power plants, current practice dictates dosing with ammonia or volatile amine compounds to maintain the $\mathrm{pH}$ above 9 and keeping oxygen concentration in the condensate as low as possible $(<0.005 \mathrm{mg} / 1)$. This low oxygen, high pH type of treatment tends to drive the above reaction in the reverse direction. From the solubility product for the reaction

$$
\mathrm{Fe}(\mathrm{OH})_{2}(\mathrm{~s})=\mathrm{Fe}^{++}+2 \mathrm{OH}^{-} \quad \mathrm{K}_{\mathrm{sp}}=7.9 \times 10^{-16}
$$

iron (II) concentration at $\mathrm{pH} 8$ is $44 \mathrm{mg} / 1$. Raising the $\mathrm{pH}$ value by one unit leads to a reduction in iron (II) concentration to $0.44 \mathrm{mg} / 1$; only at $\mathrm{pH} 9.5$ does solubility of the bivalent ion $(0.04 \mathrm{mg} / 1)$ lie at the desired order of magnitude of high pressure boilers $(<0.01 \mathrm{mg} / 1)$. If the 
amount of loosely adhering corrosion products on steel piping is measured, an identical pH dependence is found; only above $\mathrm{pH} 9$ does corrosion become negligible (See Figure 22) ${ }^{(64)}$.

An alternative to the above practice, which may be attractive for use in dry cooled systems, is the "neutral method of operation" described earlier. This system of water chemical control requires maintenance of the $\mathrm{pH}$ in the range of 6.5 to 7.5 , oxygen concentration of $150-200 \mu \mathrm{g} / 1$ (dosed as $\mathrm{H}_{2} \mathrm{O}_{2}$ ), and specific conductance $<0.2 \mathrm{umho} / \mathrm{cm}$. The relatively high oxygen concentrations recommended by this method may seem incongruous in light of previous statements that the overall corrosion rate of iron is accelerated by dissolved oxygen. The key to successful operation of this method is low dissolved solids concentration coupled with the passivating action of oxygen. Figure $23^{(64)}$ shows that the corrosion rate of carbon steel is reduced to very lov! values in oxygen-saturated water when the specific conductance is reduced to $0.1 \mu \mathrm{mho} / \mathrm{cm}$. In neutral water of this high degree of purity, oxygen contributes to protective layer formation and reduction rather than enhancement of iron corrosion and dissolution. Figure 24 shows the relationship between iron corrosion rate and oxygen concentration in flowing high-purity water. In the absence of oxygen $(<0.005 \mathrm{mg} / 1)$, Figure 25 shows that the corrosion rate of iron in flowing, high purity neutral, water is on the order of $14 \mathrm{mg} / \mathrm{dm}^{2} /$ day ${ }^{(64)}$.

This inhibitive effect of oxygen in neutral, high-purity water has been corroborated by other workers $(23,24,26,65)$. Bakay and Szabo $(23)$ state that 100-200 $\mu \mathrm{g} / 1$ oxygen is optimum in the temperature range below $250^{\circ} \mathrm{C}\left(480^{\circ} \mathrm{F}\right)$. Their experience shows the necessity of condensate polishing to maintain the necessary high water purity. Freier ${ }^{(26)}$ concludes that $60 \mathrm{lg} / 1$ nxygen in a neutral feedwater system forms a protective layer on steel that substantially decreases the iron corrosion products carried by the feedwater. Above $150^{\circ} \mathrm{C}\left(300^{\circ} \mathrm{F}\right), 25 \mu \mathrm{g} / 1$ oxygen is sufficient to form the protective oxide.

Brush and Pearl ${ }^{(24)}$ have shown that oxygen in concentrations of 15 to $2000 \mu \mathrm{g} / 1$ is an effective corrosion inhibitor in neutral $\mathrm{pH}$, high-purity, continuously purified water in the range of $38-204^{\circ} \mathrm{C}\left(100-400^{\circ} \mathrm{F}\right)$. Table 21 shows 


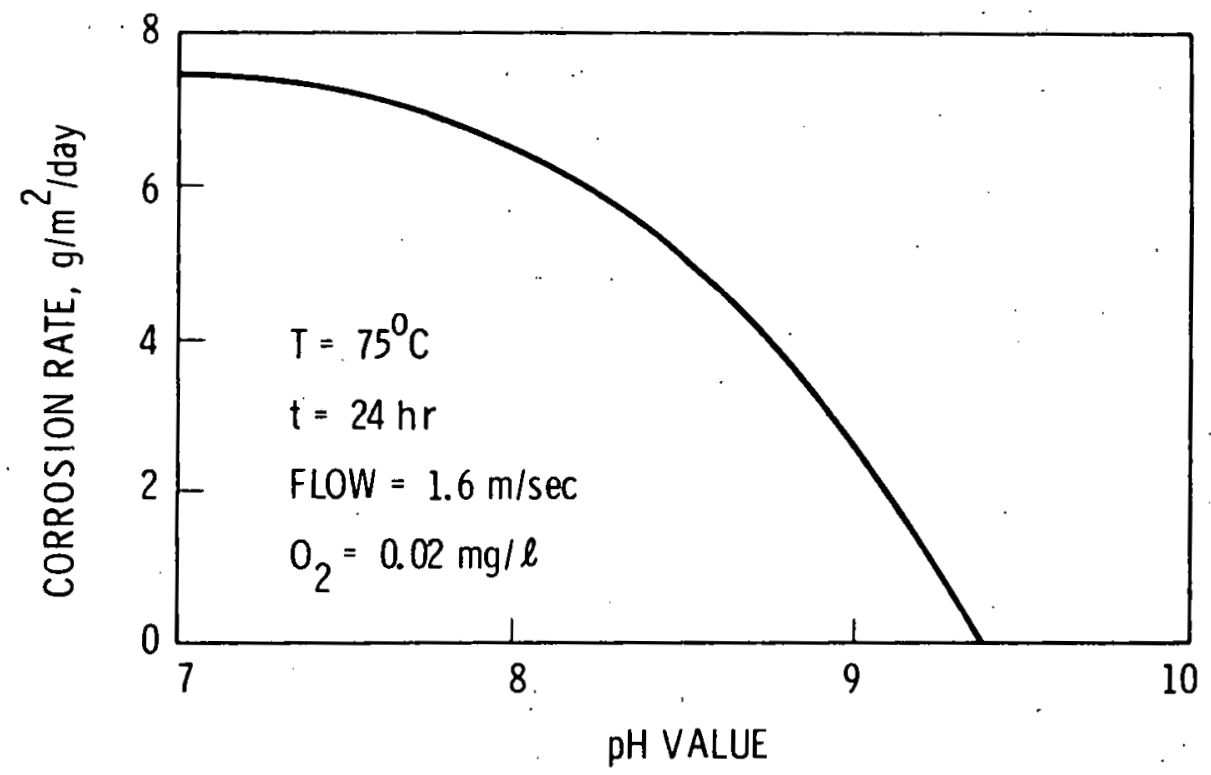

FIGURE 22. Dependence of the Corrosion Rate of Carbon Steel on pH Maintained by Ammonia (64)

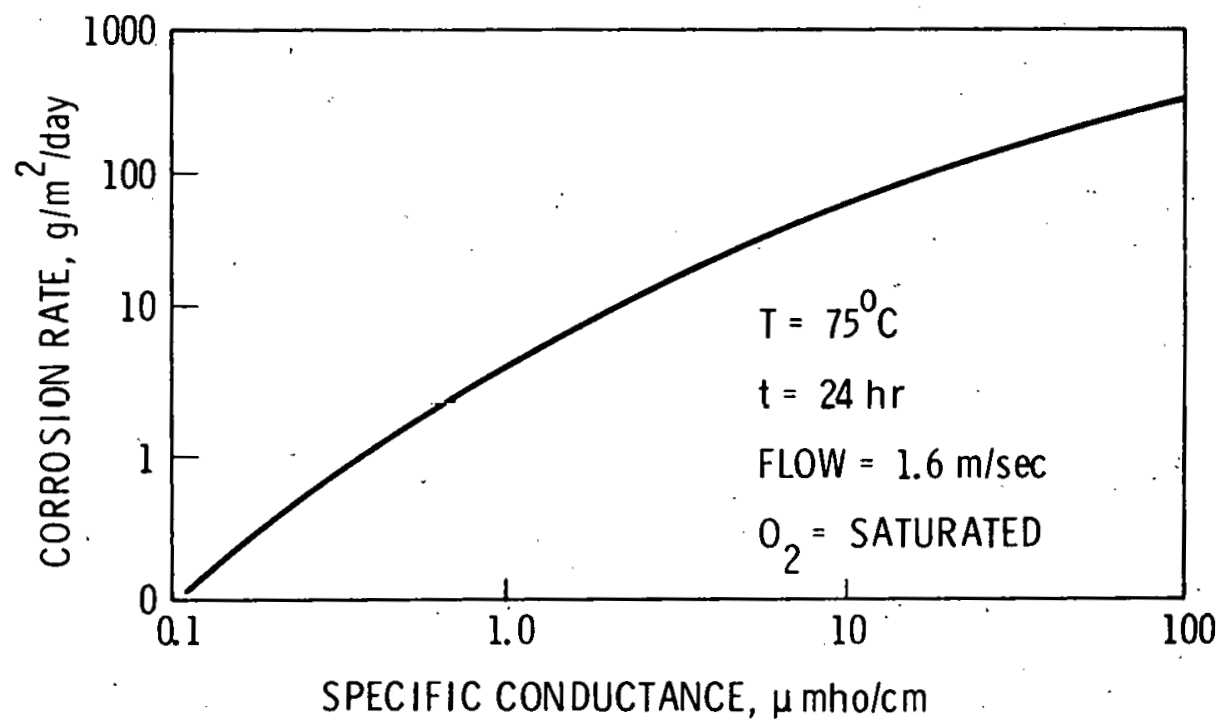

FIGURE 23. Dependence of the Corrosion Rate of Carbon Steel on Water Purity in Oxygen-Saturated Water (64) 


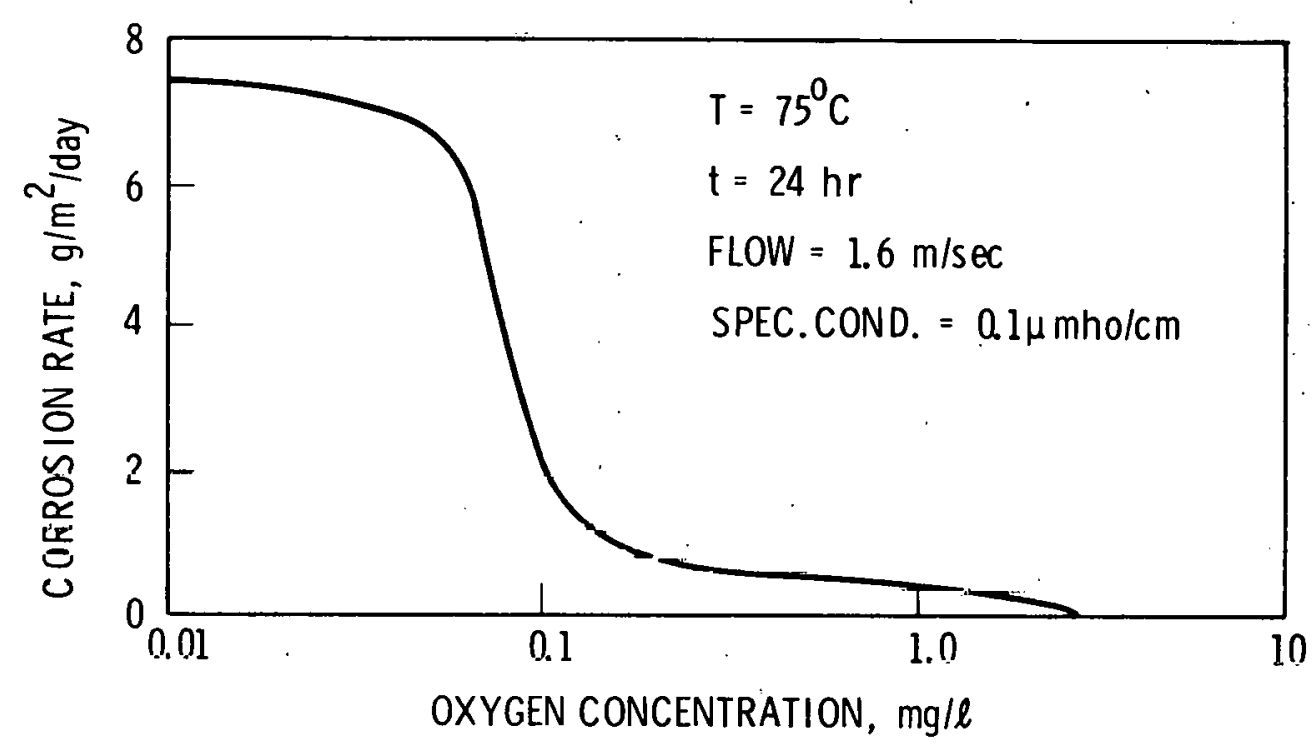

FIGURE 24. Dependence of Carbon Steel Corrosion Rate on Oxygen Concentration in High Purity Water (64).

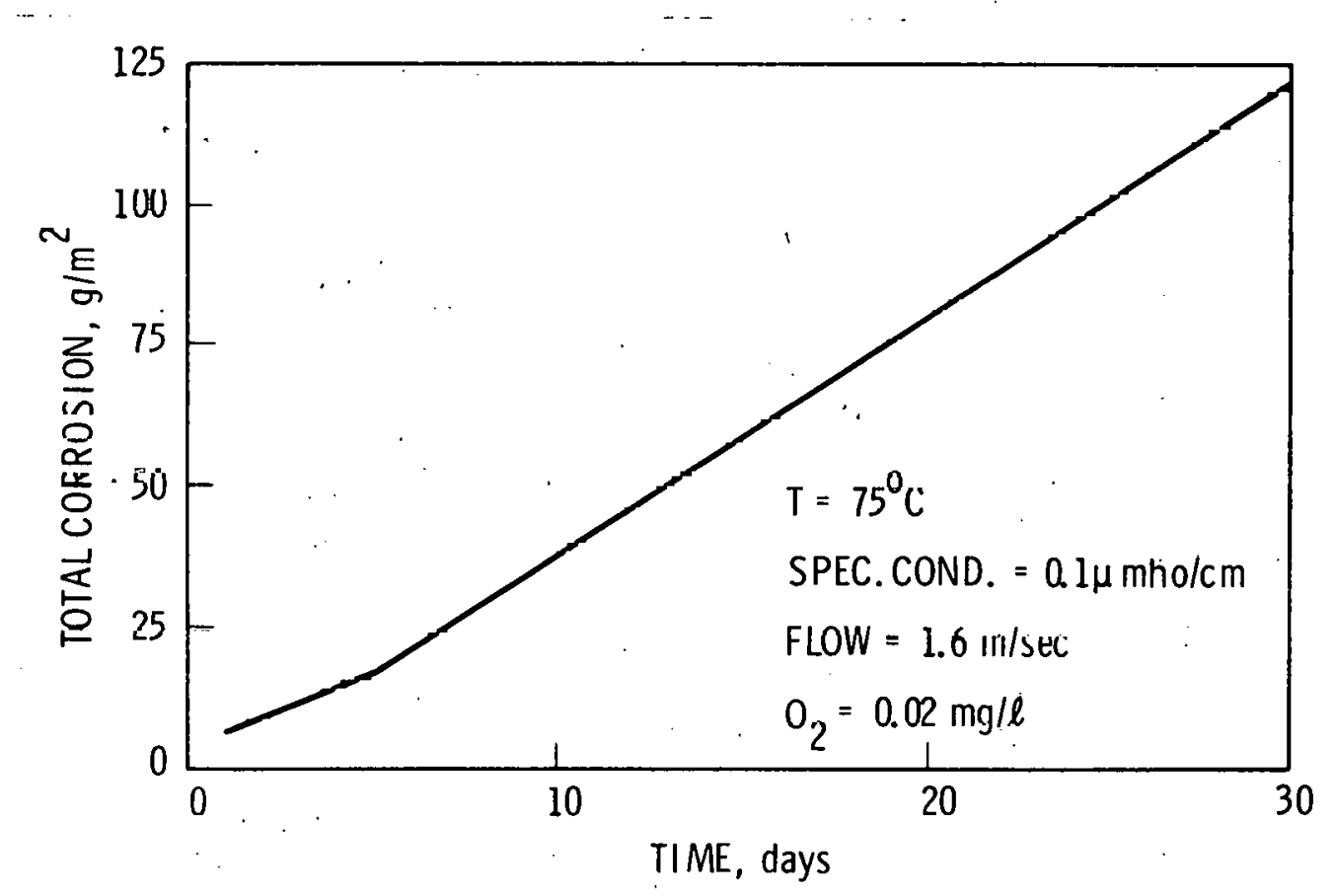

FIGURE 25. Corrosion Rate of Carbon Steel in Neutral, High Purity Water at Very Low Dissolved Oxygen Concentration (64) 
that this inhibitive effect of oxygen reduces the corrosion product release rate from carbon steel by factors of 40 to 70 over the losses found in neutral feedwater containing less than $10 \mu \mathrm{g} / 1$ oxygen.

In a dry cooling application, use of the "neutral method of operation" would require a water treatment plant capable of producing $0.1 \mu \mathrm{mho} / \mathrm{cm}$ water and condensate polishing facilities for maintaining that quality. The costs of treating waters of various quality to a very high purity are given in Appendix C.

For stainless steel, Brush and Pearl ${ }^{(24)}$ found that corrosion and release rates are less than $2.0 \mathrm{mg} / \mathrm{dm}^{2} / \mathrm{mo}$ in flowing $(1.8 \mathrm{~m} / \mathrm{sec})$ neutral feedwater containing more than $15 \mu \mathrm{g} / 1$ oxygen. At the temperature of interest to dry cooling applications (up to $66^{\circ} \mathrm{C}$ ), the corrosion rate of Type 304 stainless steel is $<0.1 \mathrm{mg} / \mathrm{dm}^{2} / \mathrm{mo}$ with flowing, neutral, high-purity water containing $200 \mu \mathrm{g} / \mathrm{T}$ oxygen (see Table 22).

\section{TABLE 21}

EFFECT OF VELOCITY AND WATER PURITY ON CORROSION PRODUCT RELEASE FROM CARBON STEEL ${ }^{(24)}$

\begin{tabular}{|c|c|c|c|c|c|c|c|c|}
\hline Temp, ${ }^{\circ} \mathrm{C}$. & $\begin{array}{c}\text { Conductivity, } \\
\mu \mathrm{mho} / \mathrm{cm}\end{array}$ & $\begin{array}{c}\text { Oxygen } \\
\text { Content, } \mu \mathrm{g} / 1 \\
\end{array}$ & \multicolumn{6}{|c|}{$\frac{\text { Release Rate, } \mathrm{mg} / \mathrm{dm}^{2} / \mathrm{mo}}{\text { Velocjty } \mathrm{m} / \mathrm{sec}}$} \\
\hline 38 & 0.1 & 3 & - & - & - & 218 & 280 & 328 \\
\hline 38 & 0.1 & .200 & - & - & - & 21 & - & 24 \\
\hline 52 & 0.1 & 5000 & 278 & 12 & 3 & 2 & - & - \\
\hline 52 & 3.6 & 5000 & 515 & 46 & 52 & 12 & - & $=$ \\
\hline 204 & 0.1 & 3 & - & - & - & 175 & 292 & 196 \\
\hline 204 & 0.1 & 200 & - & - & - & 13 & 3 & .16 \\
\hline
\end{tabular}


TABLE 22. Type 304 Stainless Steel Corrosion and Release in Neutral, High-Purity $(0.1 \mu \mathrm{mho} / \mathrm{cm})$ Flowing $(1.8 \mathrm{~m} / \mathrm{sec}$. Water. (24)

$3 \mu \mathrm{g} / 1 \mathrm{O}_{2}$

Corrosion Rate Release, Rate

Temp, ${ }^{\circ} \mathrm{C}$ 38

66

93

12.1

149

177

204 $\mathrm{mg} / \mathrm{dm}^{2} / \mathrm{mo}$

$-\cdots$

0.8

0.1

1.0

2.1

3.5

7.5

\begin{abstract}
$\mathrm{mg} / \mathrm{dm}^{2} / \mathrm{mo}$
\end{abstract}
$--$

0.8

0.7

1.0

2.0

3.4

7.3

\begin{tabular}{|c|c|}
\hline $\begin{array}{c}\text { Corrosion Rate } \\
\mathrm{mg} / \mathrm{dm}^{2} / \mathrm{mo}\end{array}$ & $\begin{array}{l}\text { Release } \text { Rate } \\
\mathrm{mg} / \mathrm{dm}^{2} / \mathrm{mo} \\
\end{array}$ \\
\hline$<0.1$ & $=0.1$ \\
\hline$<0.1$ & $<0.1$ \\
\hline$<0.1$ & $<0.1$ \\
\hline 0.6 & $<0.1$ \\
\hline 1.2 & $<0.1$ \\
\hline 1.4 & $<0.1$ \\
\hline 1.5 & 0.1 \\
\hline
\end{tabular}

\subsubsection{Corrosion Mechanisms}

\section{Stress Corrosion Crackina}

The austenitic stainless steels of the types used in modern condensers (304 and 316) are subject to stress corrosion cracking in chloride environments. The time to failure by stress corrosion has been found to be decreased markedly by an increase in temperature ${ }^{(66)}$. It has been reported that in concentrated chloride solutions at low temperatures oxygen has little influence on the time to failure under-stress ${ }^{(67)}$. A decrease in $\mathrm{pH}$ tacilitates cracking of austenitic stainless steels in magnesium chloride solutions $(66,67)$.

Thomas, et al. ${ }^{(68)}$ established that temperature has a considerably greater effect on the time to failure at a given stress in $\mathrm{MgCl}_{2}$ solutions than does chloride ion concentration. This is substantiated by the work of Sugimoto, et al. ${ }^{(69)}$, who found that at low temperatures $\left(100^{\circ} \mathrm{C}\right)$ only saturated chloride solutions would cause cracking of Type 304 stainless steel, while at high temperatures $\left(3 n n^{\circ} \mathrm{C}\right) 100 \mathrm{mg} / 1$ chloride is sufficient to cause cracking. 
Thus the susceptibility of stainless steels to stress corrosion cracking has been shown to increase with increasing temperature and chloride concentration. Chloride concentration and temperature will be relatively low in dry cooling tower environments, suggesting that stress corrosion cracking of candidate stainless steels will not generally be a problem.

Intergranular Attack

Improper heat treatment of stainless steels can cause the grain boundaries to become particularly susceptible to corrosion. The specific temperatures and times that induce this susceptibility are known as sensitizing heat treatments, which cause chromium to diffuse to the grain boundaries and precipitate chromium carbides. For the austenitic alloys under consideration for dry cooling applications the sensitizing temperature range is 400 to $850^{\circ} \mathrm{C}\left(752\right.$ to $\left.1562^{\circ} \mathrm{F}\right)$. The higher the temperature, the shorter is the time required for sensitization $(32)$.

Welding is probably the most common cause of susceptibility of intergranular corrosion $(70)$. Spot welding does not cause sensitization, but arc welding can cause damage, the effect being greater the longer the heating time, especially when heavy-gage material is involved. Sensitizing temperatures occur at a distance of several millimeters on either side of the weld. Hence, on exposure to a corrosive environment, failure of an austenitic stainless steel weld (called weld decay) occurs in zones slightly away from the weld rather than within the weld.

Most service experiences of intergranular corrosion have been in oxidizing acids; some problems have been experienced in seawater environments. The possibility of intergranular attack of sensitized austenitic stainless steel is a current problem in nuclear reactor operation, but it appears to occur at temperatures near $300^{\circ} \mathrm{C}$. The stainless steel is sensitized when carbon steel vessels to which it is attached are stressed relieved. Also, laboratory studies have shown that moisture and fluoride ions from fumes or spatter produced by welding with coated electrodes can cause intergranular attack of sensitized stainless steel. (71) pure water can attack sensitized 
type 430 ferritic stainless. However, in high-purity water systems used in dry cooling facilities, serious intergranular attack is not expected to be a problem with austenitic stainless steels.

\section{Pitting Corrosion}

Stainless steels exposed to seawater develop deep pits within months; the pits initiate usually at crevices or other areas of stagnant electrolyte. The austenitic stainless steels are more resistant than the martensitic or ferritic types; resistance increases as the nickel content increases. The austenitic alloys containing molybdenum (i.e., Type 316) are still more resistant; however, crevice corrosion and pitting of these alloys may occur in seawater in one to two years.

Pitting resulting from crevice corrosion is favored whenever a stainless steel is covered by an organic or inorganic film or by marine fouling organisms, which shield the surface from access to oxygen. It is therefore important to ensure that stainless steel heat exchanger surfaces remain clean. Cleanliness can be maintained by operating at moderately high water velocities (stainless steel is resistant to velocities in excess of $4.6 \mathrm{~m} / \mathrm{sec}$ ); this water movement also tends to keep all the surface on contact with aerated water and uniformiy passive.

Larbon and low-alluy steel component's arc susceptible to pitting corrosion during transfer and storage unless they are purged and contain a desiccant to maintain low humidity and are sealed to prevent ingress of high humidity air. Failure to remove rust prior to uperdiciu can lead to pitting when the unit is operated with water or steam at high temperatures. During down time, air must be excluded from carbon steel units if they remain wet to avoid pitting $(71)$.

\section{Fretting Corrosion}

Fretting corrosion was defined in the section on copper-base alloys. Laboratory experiments have shown that fretting corrosion of steel versus steel requires oxygen but not moisture ${ }^{(72)}$; however, fretting can occur when water is present. Fretting in the absence of oxygen may also produce mechanical damage. Damage increases as temperature is lowered. Brass in contact with steel tends to be less damaging than steel versus steel; combinations 
of stainless steels tend to be worst. As indicated previously, the typical number of fretting cycles to initiate a crack have been found to be 30,000 for steels; 100,000 for age-hardened aluminum alloys; and 350,000 for copper alloys $(37)$. These data are given to show the relative resistance of the materials to fretting corrosion. Actual service performance is strongly dependent upon conditions. Fretting problems in dry cooling facilities can be reduced or eliminated by proper design to avoid relative vibration of mating parts.

\section{Corrosion Fatigue}

For steels there exists a stress level, called the fatigue limit, below which failure will not occur regardless of the number of stress cycles. This fatigue limit is approximately half the tensile strength. In a corrosive environment, failure at a given stress level usually occurs within fewer cycles, and a true fatigue limit is no longer observed (See Figure $26^{(32)}$ ).

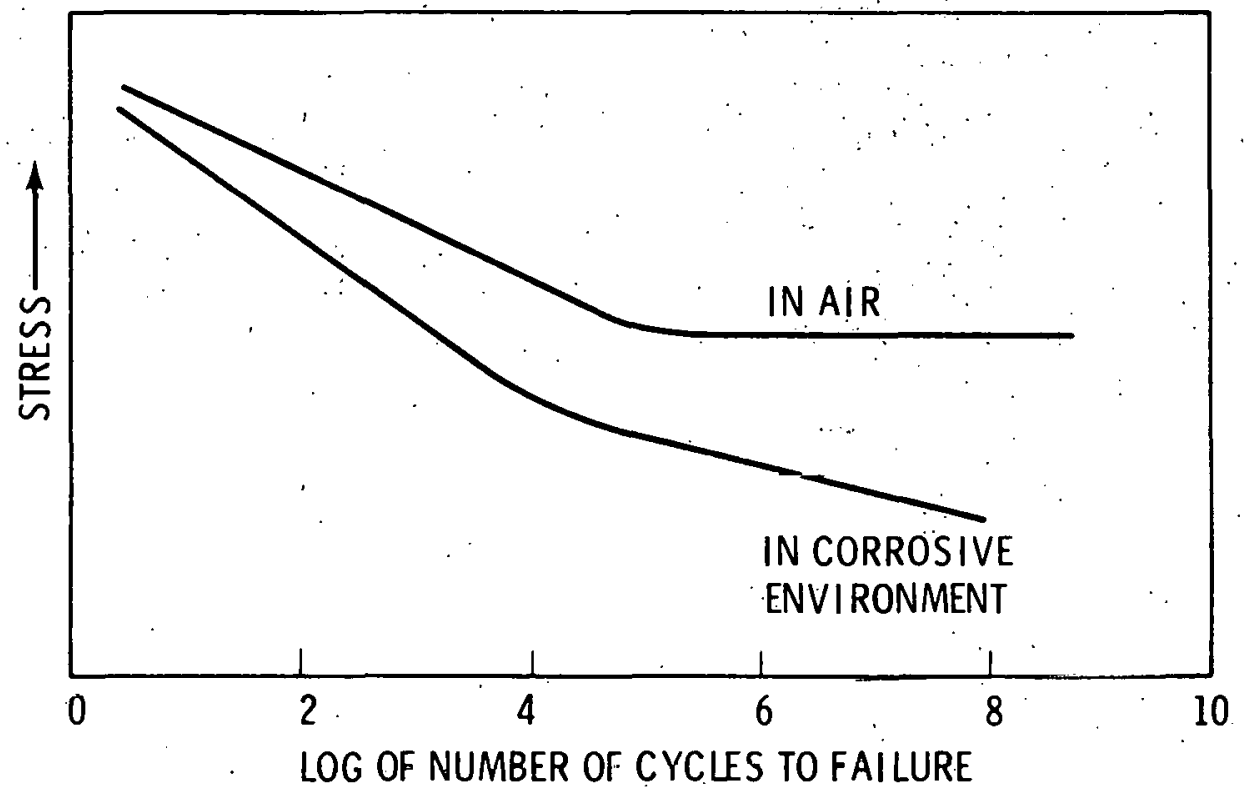

FIGURE 26. Relationship of Number of Cycles to Failure to Stress for Steels Subjected to Cyclical Stress. (32) 
Steel suffers corrosion fatigue in fresh waters, seawaters, and numerous other aqueous environments. The general rule is that the higher the uniform corrosion rate, the shorter the resultant fatigue life. (32)

Problems due to corrosion fatigue can be minimized by controlling water chemistry so that the overall corrosion rate is minimized.

\section{Erosion Corrosion}

The effect of velocity on the corrosion rate of steels is directly related to other. water quality parameters such as dissolved solids and oxygen content. Brush and Pearl ${ }^{(24)}$ found that the release rate of corrosion products from carbon steel increases with velocity (from 1.8 to $7.3 \mathrm{~m} / \mathrm{sec}$ ) in neutral, high purity $(0.1 \mu \mathrm{mho} / \mathrm{cm})$ water at $38^{\circ} \mathrm{C}$ with an oxygen content of $3 \mu \mathrm{g} / 1$; however, with $200 \mu \mathrm{g} / 1$ of oxygen the release rate is an order of magnitude lower and almost independent of velocity. (See Table 21) Release rate decreases markedly with velocity at an oxygen level of $5 \mathrm{mg} / 1$, being only $2 \mathrm{mg} / \mathrm{dm}^{2} / \mathrm{mo}$ at $1.8 \mathrm{~m} / \mathrm{sec}(6 \mathrm{fps}$ ). This decrease is due to a protective oxide resulting from the increased oxygen supply at higher velocity.

Applying the findings of Table 21 to dry cooling piping applfcaliurs and assuming that some oxygen $(2150-200 \mu \mathrm{g} / \mathrm{l})$ is maintalned ill the highpurity water ( 0.1 jmho/cill) sysleili to 'bring about passivity' as describer elsewhere in this paper, water velocities in carbon steel piping can be up t. $3.6 \mathrm{~m} / \mathrm{sec}(12 \mathrm{fps})$ with a corrosion rate of $\sim 5$ to $10 \mathrm{mg} / \mathrm{dm}^{2} / \mathrm{mo}$. Doubling this velocity results in a corrosion rate of $\sim 15$ to $20 \mathrm{mly} / \mathrm{dm}^{2} / \mathrm{mo}$; however, the velocity design point should be lower than $7.3 \mathrm{~m} / \mathrm{sec}(24 \mathrm{fps})$ to provide protection against increased corrosion in turbulent areas where water velocity will be higher than in the bulk fluid. Also, corrosion rates of 10 to $15 \mathrm{mg} / \mathrm{dm}^{2} /$ mo may be detrimental in nuclear systems from the standpoint of corrosion product transport.

Up to $1.0 \mathrm{~m} / \mathrm{sec}(3.3 \mathrm{fps})$ Butler and Stroud $(73)$ determined that the rate of mild steel corrosion is proportional to the cube root of the flow velocity (see Figure 27) in aerated, high-purity water. These workers 
determined the rate of corrosion of mild steel in high-purity, aerated, flowing $(2.0 \mathrm{~m} / \mathrm{sec})$ water at $55^{\circ} \mathrm{C}$ to be $68 \mathrm{mg} / \mathrm{dm}^{2} /$ day. However, this is the initial corrosion rate; the rate can be expected to decrease with time and drop to a steady state value more in accord with the finding of Brush and Pearl, whose data resulted from tests in excess of 5000 hours.

Brush and Pearl showed that the corrosion rate of type 304 stainless steel is $<0.1 \cdot \mathrm{mg} / \mathrm{dm}^{2} / \mathrm{mo}$ in flowing $(1.8 \mathrm{~m} / \mathrm{sec})$ high purity water at $65^{\circ} \mathrm{C}$ with $200 \mu \mathrm{g} / 1$ dissolved oxygen: With only $3 \mu \mathrm{g} / 1$ dissolved oxygen, the

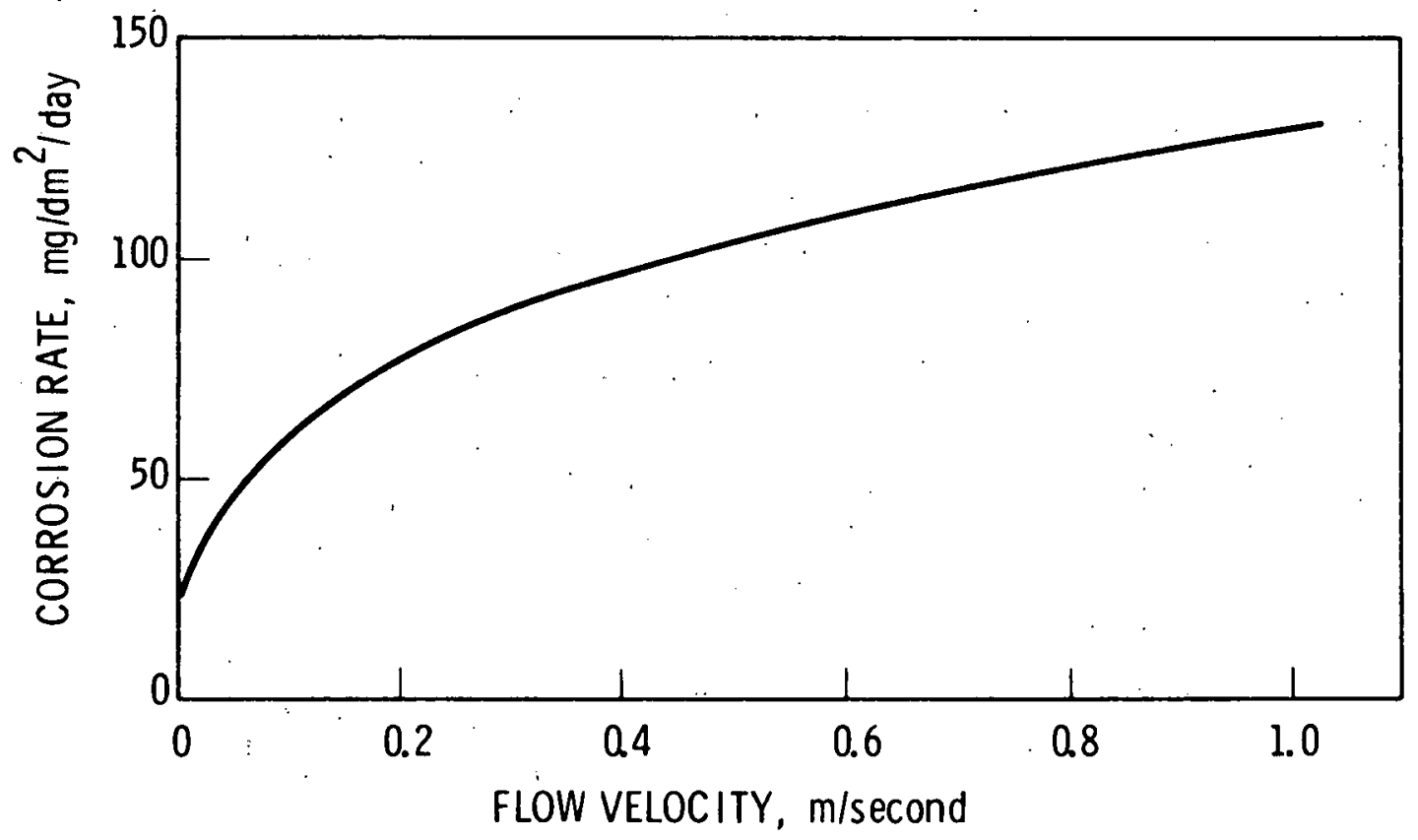

FIGURE 27. Variation of the Corrosion Rafe of Mild Steel with Flow Rate up to $1.0 \mathrm{~m} / \mathrm{sec}(73)$ 
corrosion rate is $0.8 \mathrm{mg} / \mathrm{dm}^{2} / \mathrm{mo}$ under the same conditions (24). Hager (51) cites the resistance of Types 304 and 316 to velocities in excess of 4.6 $\mathrm{m} / \mathrm{sec}$ (15 fps) as advantageous to their use as condenser materials. Milleville $\mathrm{f}^{(74)}$ gives justification for increasing the velocity in feedwater piping from $3.0 \mathrm{~m} / \mathrm{sec}(10 \mathrm{fps})$ to $10.7 \mathrm{~m} / \mathrm{sec}(35 \mathrm{fps}$ ) and states that velocities as high as $30.5 \mathrm{~m} / \mathrm{sec}$ (100 fps) will not cause an unacceptable degree of erosion corrosion.

\section{Corrosion Product Transport}

The release rates of corrosion products from carbon steel and Typè 304 stainless steel into continuously purlfled flowing waler have been given previously. (Tables 21 and 22). Aqain, these data indicate the drastically reduced corrosion and release rates in water containing some oxygen.

In closed, nonrefreshed circulating systems, the corrosion product release rates will be limited by their solubilities. Concerning the dissolution of corrosion products, the pertinent reactions, from Stumm and Lee ${ }^{(75)}$ arre:

$$
\begin{array}{ll}
\mathrm{Fe}(\mathrm{OH})_{2}(\mathrm{~s})=\mathrm{Fe}^{2+}+2 \mathrm{H}^{-} & \log \mathrm{K}=-15.1 \\
\mathrm{Fe}(\mathrm{OH})_{2}(\mathrm{~s})=\mathrm{Fe}(\mathrm{OH})^{+}+\mathrm{OH}^{-} & \log \mathrm{K}--9.40 \\
\mathrm{Fe}(\mathrm{OH})_{2}(\mathrm{~s})+\mathrm{OH}^{-}=\mathrm{Fe}(\mathrm{OH})_{3}^{-} & \log \mathrm{K}=-5.09 \\
\mathrm{Fe}(\mathrm{OH})_{3}(\mathrm{~s})=\mathrm{Fe}^{3+}+3 \mathrm{H}^{-} & \log \mathrm{K}=-36 \\
\mathrm{Fe}(\mathrm{OH})_{3}(\mathrm{~s})=\mathrm{Fe}(\mathrm{OH})_{2}^{+}+\mathrm{OH}^{-} & \log \mathrm{K}=-14.77 \\
\mathrm{re}(\mathrm{OH})_{3}(\mathrm{~s})=\mathrm{Fc}(\mathrm{OH})^{2+}+2 \mathrm{H}^{-} & \log \mathrm{K}=-24.17 \\
\mathrm{Fe}(\mathrm{OH})_{3}(\mathrm{~s})=\mathrm{Fe}(\mathrm{OH})_{3}(\mathrm{~d}) & \log \mathrm{K}=-6.54 \\
\mathrm{Fe}\left(\mathrm{OH}{ }_{3}(\mathrm{~s})+\mathrm{OH}^{-}=\mathrm{Fe}(\mathrm{OH})_{4}^{-}\right. & \log \mathrm{K}=-5
\end{array}
$$

The dependence of solubilities of $\mathrm{Fe}(\mathrm{OH})_{2}(\mathrm{~s})$ and $\mathrm{Fe}(\mathrm{OH})_{3}(\mathrm{~s})$ on $\mathrm{pH}$ is shown in Figures 28 and 29. In low oxygen systems in which the corrosion product is ferrous hydroxide, $\mathrm{Fe}(\mathrm{OH})_{2}(\mathrm{~s})$, minimum solubility occurs at a! pH of 11.8 . 


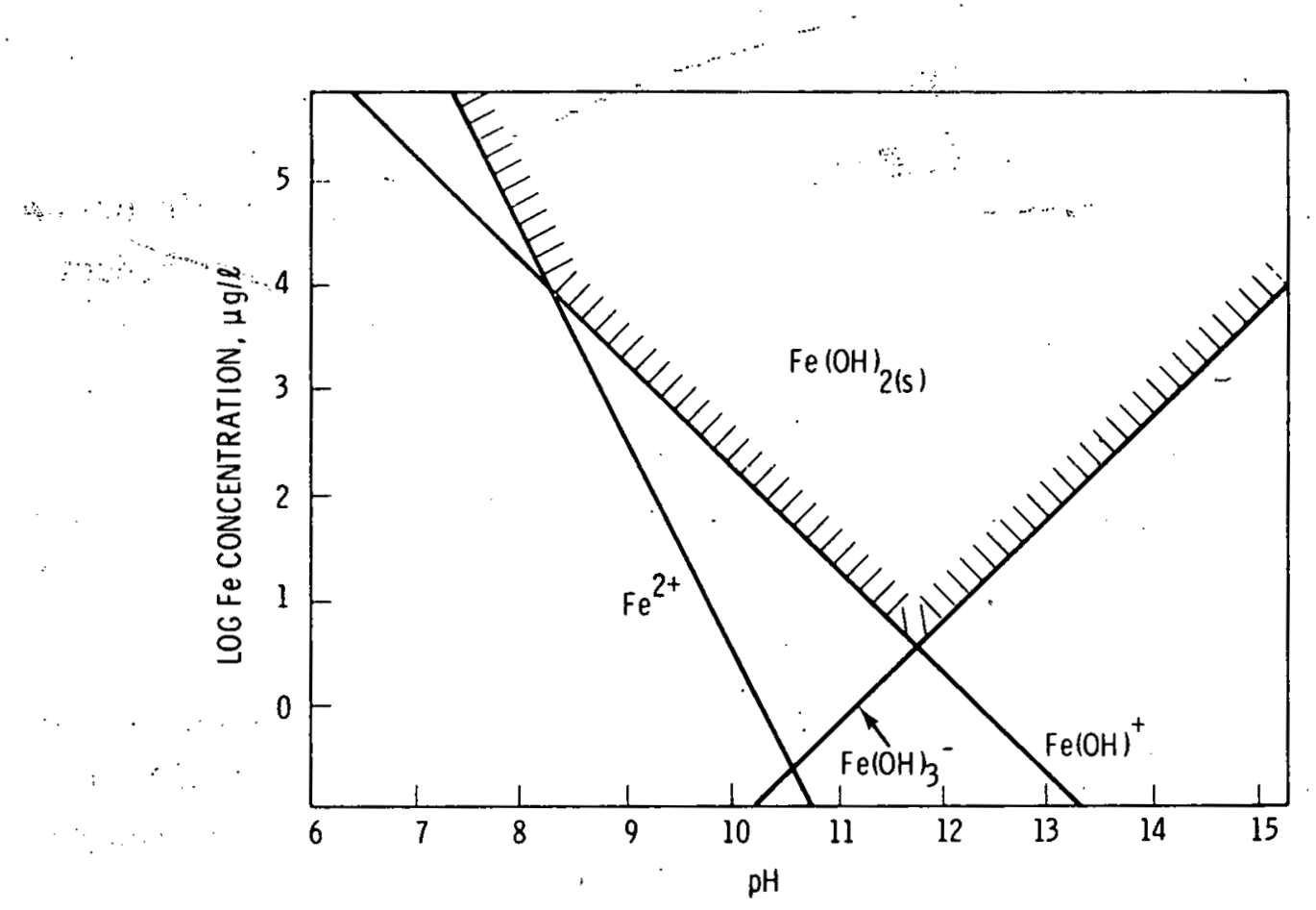

FIGURE 28. $\mathrm{pH}$ Dependence of the Solubility of $\mathrm{Fe}(\mathrm{OH})_{2(\mathrm{~s})}$ at $25^{\circ} \mathrm{C}$

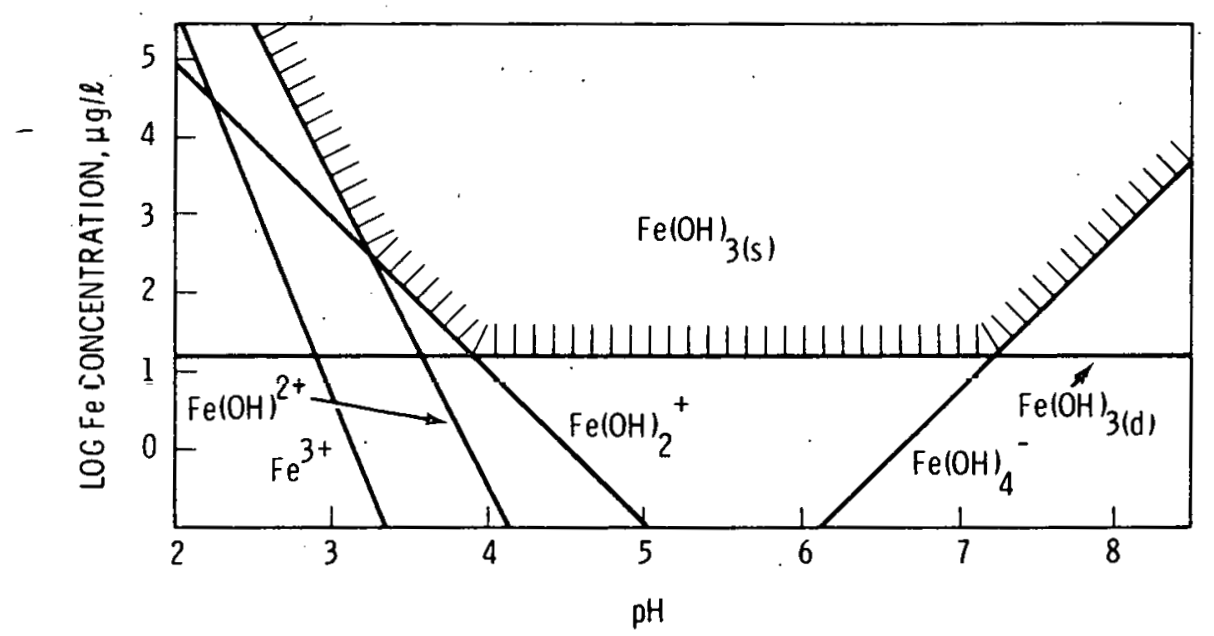

FIGURE 29. $\mathrm{pH}$ Dependence of the Solubility of $\mathrm{Fe}(\mathrm{OH})_{3(\mathrm{~s})}$ at $25^{\circ} \mathrm{C}$ 
The total $\mathrm{Fe}(\mathrm{II})$ concentration at this $\mathrm{pH}$ is about $6.4 \mu \mathrm{g} / \mathrm{l}$, the major solubilized species being $\mathrm{Fe}(\mathrm{OH})^{+}$and $\mathrm{Fe}(\mathrm{OH})_{3}^{-}$. In systems containing oxygen, amorphous ferric hydroxide, ferric oxide hydroxide and ferric oxide are the principal corrosion products. The $\mathrm{pH}$ of minimum corrosion product solubility is about 9 , the major solubilized species being undissociated molecular ferric hydroxide, $\mathrm{Fe}(\mathrm{OH})_{3}(\mathrm{~d})^{*}$ at a concentration of about $16 \mu \mathrm{g} / 1$. If only the dissociated species are considered, the total soluble ferric iron at $\mathrm{pH} 9$ is on the order of 10 nanograms per liter (parts per trillion).

Regarding the "neutrai meethod of operaling," sulubilized species in slightly oxygenated water at $\mathrm{pH} 7$ will be $\mathrm{Fe}(\mathrm{OH})_{3}(\mathrm{~d})^{\star}, 16 \mu \mathrm{g} / 1 \mathrm{Fe}(\mathrm{OH})_{2}^{+}$, about $1 \mathrm{~kg} / 1$ and $\mathrm{Fe}(\mathrm{OH})_{4}^{-}, 3 \times 10^{-3} \mathrm{\mu g} / 1$. This is not significantly greater than the amount of solubilized corrosion products in systems operating at conventional pH $(8.5-9.5)$, and as shown previously the overall corrosion rates are much less.

The importance of minimizing overall corrosion as well as corrosion product dissolution must again be emphasized; deposition can result directly from the insoluble corrosion product without a transition through some soluble state ${ }^{(61)}$. Reference is made to page 82 for the relationship between bivalent copper and bivalent iron concentrations with regard to metallic copper and ferric oxide deposition.

* $\mathrm{Fe}(\mathrm{OH})_{3}(\mathrm{~d})$ is dissolved molecular (undissociated) ferric hydroxide. 


\subsection{ATMOSPHERIC CORROSION OF CANDIDATE MATERIALS}

\subsubsection{Candidate Materials}

The principal state-of-the-art materials which are exposed on the air-side of air-cooled heat exchangers are:

- aluminum alloys

- copper alloys

- carbon steel

- : stainless stee?

- gàlvanized steel

The two prime candidates for dry cooling tower applications are aluminum alloys and galvanized steel. The survey cited in Section 3 indicated that these are the only two fin materials installed in existing drycooled power stations. Copper-base alloys are used for fins and tubes in dry coolers. However, copper has been largely displaced by aluminum for fin materials. Air-side exposure of steels occurs principally in applications such as louvers, headers and structural members. Steel finned tubes are used in some high-temperature aerial coolers in the chemical process industry.

Titanium finned tubes are fabricated for high-integrity installations, but are not likely to penetrate the dry cooling tower market in the foreseeable future unless significant reductions occur in the relative costs of titanium and the present candidates.

\subsubsection{Relevance of Atmospheric Corrosion Data}

There is a large body of atmospheric corrosion data which is relevant to dry cooling tower corrosion under prestartup and shutdown conditions. However, the data have no application to finned tube corrosion behavior while the plant is on-line, with the finned surfaces warm and dry. There is presently no power plant quantitative data base for finned surface corrosion under plant operating conditions. However, there is a relatively large experience factor from numerous industrial coolers which first went into operation about 21935 (Sections 1 and 2) and which operate at near the same fluid temperatures and ambient conditions. This experience indicates that 
corrosion from the air-side is a minimal problem in air-cooled heat exchangers because operation above the dew point minimizes exposure to the corrosive effect of moisture.

\subsubsection{Atmospheric Corrosion Characteristics}

Sereda ${ }^{(76)}$ summarized the important factors which influence the weathering of metals. Atmospheric corrosion data are available for a variety of metals and corrosion environments. While some corrosion problems continue to occur due to mismatching of Illderials and environments, proper intcrpretation of the data provide a substantial basis for avoiding these problems. At the same time, it is necessary to recognize the wide variability in atmosphertc corrosion for a given material over a varlety of sites. Larrabee and Ellis (77) found that the ratio of maximum to minimum corrosion for steel at 46 sites was 1570:1. The ratio of corrosion rates, steel-to-zinc, varied from 2:1 at Norman Wells to 118:i at Kure Beach. In approaching the question of site selection, it is important to recognize the factors which influence the variability in atmospheric corrosion rates. The need for specific onsite corrosion evaluations also is indicated, particularly for plants where large capital expenditures are committed.

The most important atmospheric corrosion parameters include: (76)

Moisture - Time-of-wetness shows a substantial correlation with corrosion, and is proposed to be the most important factor promoting atmospheric corrosion of metals. There is evidence, at least for steel and aluminum, that periodic wetting results in higher corrosion rates than continuous immersion. (78)

Pollutants - Atmospheric pollutants identified with corrosion include $\mathrm{SO}_{2}, \mathrm{H}_{2} \mathrm{~S}, \mathrm{NH}_{3}$, nitrates, nitrites, halide salts and particulate matter. Interaction of the pollutants with moisture to form corrosive electrolytes is the principal factor in atmospheric corrosion. The possible synergistic interactions among the range of atmospheric pollutants is complex and not well defined. However, comprehensive atmospheric monitoring programs are providing a substantial basis for evaluating effects of pollutants on corrosion. 
Proximity to Salt Water - Marine environments are generally regarded as being aggressive toward many construction materials. However, comparative data at Kure Beach sites $25 \mathrm{~m}$ and $250 \mathrm{~m}$ from the ocean indicated that corrosion rates were an order of magnitude higher at the closer site. Corrosion rates 1 to $2 \mathrm{~km}$ from shore are several fold lower than rates at the seashore. These observations have obvious implications to site selection for power stations utilizing dry-cooled equipment. However, each site must be evaluated individually to determine how far from the shoreline the marine environment actually extends.

Effects of Corrosion Products - Many metals form protective layers after a few years, which substantially reduce rates of atmospheric weathering. While no single curve can provide an adequate summary of this complex characteristic, Figure 30 is a qualitative summary of the passivating tendency of various metals under atmospheric exposure. (80) These curves reflect the well known ability of aluminum, copper and lead to develop stable, protective corrosion layers, while zinc, and particularly unalloyed iron, exhibit relatively rapid corrosion responses. The high corrosion rates indicated for zinc are somewhat misleading in the context of dry cooling equipment, since zinc-coated (galvanized) materials fare well in many atmospheric environments. On the other hand, in aggressive environments, zinc does tend to become annitir to most metal substrates, providing sacrificial protection.

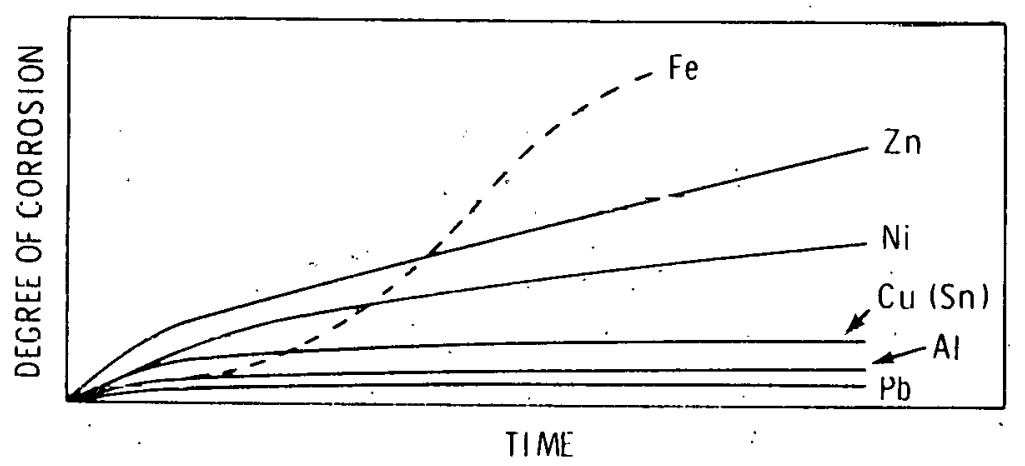

FIGURE 30. Characteristic Kinetic Corrosion Curves for Atmospheric Corrosion of Various Metals $(80)$ 
Temperature - Effects of temperature on atmospheric corrosion are generally not large and are often masked by other factors. Increasing the temperature above the dew point is generally beneficial, because it suppresses effects of moisture on corrosion. However, effects of temperature on corrosion induced by various atmospheric pollutants is not well defined.

The importance of moisture in atmospheric corrosion arises largely from its role in forming electrolytes on the metal surface. Water accumulates on a surface by temperature depression below the dew point, .... by physical adsorption on surface deposits (corrosion films, soot, $\mathrm{SiO}_{2}$, etc.) by chemical adsorption on hygroscopic salts, and by direct impingement of rain, or other precipitation. Ionizable species, deposited as particles or co-condensed with the moisture promote the electrochemical action which results in corrosion. Industrial contaminants, such as $\mathrm{SO}_{2}$ also provide electrolytes when dissolved in water. 0xygen reduction is generally the principal cathodic process in atmospheric corrosion, by the reaction:

$$
1 / 2 \mathrm{O}_{2}+\mathrm{H}_{2} \mathrm{O}+2 \mathrm{e}^{-} \rightarrow 2 \mathrm{OH}^{-} \text {. }
$$

Thus, the maximum electrochemical corrosion rate will generally occur under conditions which maximize the rate of oxygen supply to cathodic sites. Crevices and surface deposits often contribute to accelerated electrochemical corrosion by developing local concentration cells. In corrosion reactions where oxygen effects are important, temperature will play a significant role, because oxygen solubility in water decreases with temperature.

Solubilities of several gases as a function of temperature are shown in labie $23^{(78)}$ In all cases lhe sulubilities decrease with temperature However, there is a marked difference in solubility from one gas to another. The relative solubilities affect the relative corrosion character of the electrolyte on the metal surfaces in contact with contaminated a tmospheres. 
TABLE 23. Solubilities of Gases in Water (78)

Solubility (gm gas/100 $\mathrm{gm} \mathrm{H}_{2} \mathrm{O}$ ) (1 atm total P)

\begin{tabular}{lccc} 
Gas & \multicolumn{1}{c}{$10 \mathrm{C}$} & $20 \mathrm{C}$ & $\frac{30 \mathrm{C}}{7.8}$ \\
\cline { 2 - 3 } $\mathrm{SO}_{2}$ & 16.2 & 11.3 & 0.298 \\
$\mathrm{H}_{2} \mathrm{~S}$ & 0.511 & 0.385 & 3.59 \\
$\mathrm{O}_{2}$ & 5.37 & 4.34 & 15.6 \\
$\mathrm{air}$ & 22.8 & 18.7 & 5.17 \\
$\mathrm{NO}$ & 7.56 & 6.17 & 1.47 \\
$\mathrm{H}_{2}$ & 1.74 & 1.60 & 1.62 \\
$\mathrm{~N}_{2}$ & 2.31 & 1.89 & 0.094 \\
$\mathrm{C}_{2} \mathrm{H}_{2}$ & 0.150 & 0.117 & 1.90 \\
$\mathrm{CH}_{4}$ & 2.96 & 2.32 & 0.125 \\
$\mathrm{CO}_{2}$ & 0.232 & 0.169 & 0.572 \\
$\mathrm{Cl}_{2}$ & 0.997 & 0.729 & 67.3 \\
$\mathrm{HCl}^{2}$ & 77.2 & 72.1 & 65.1 \\
$\mathrm{NH}_{3}$ & 79.6 & 72.0 &.
\end{tabular}

Factors associated with the metal surface also are potentially important to promotion of atmospheric corrosion. Dissimilarities either on a macro- or microscale tend to create anodic-cathodic couples, which may result in galvanic attack, depending on the potential differences developed by the metal couples.

Residual and applied stresses are important factors in promoting corrosion failures in a broad range of materials and environmental conditions. Factors which reduce the risk of stress-induced failure include: selection of materials with demonstrated resistance to stress effects; specification of the metal at the lowest practicable intrinsic strength level; minimizing conjunctive effects of stress concentrations and zones where aggressive species can concentrate (e.g., crevices, corrosion product deposits, direct layers).

Electrochemical potentials between dissimilar metals in various service environments provide an estimate of the galvanic corrosion which may occur 
in the absence of filming or passivation. Table 24 presents electrochemical potential data for a number of metals and alloys in chloride-peroxide solution. (81) The more negative the potential, the greater is the susceptibility of the metal to corrosion in the medium. Metals at the negative end are anodic (active); metals at the positive end are cathodic (noble). The galvanic potential for any given couple can be determined from the differences of their potential read from the table. Relative potentials between metal couples can change substantially with environment, so the data in Table 24 provide only general guidance and should not be applied quantitatively to a broad range of conditions. While the electrolytes which develop in dry-cooled tin surfaces qeneral!y wlll contain chloride as an impurity, other species present may shift the potentials. Formation of passive films also shifts the potentials to more noble values. Uhlig ${ }^{(32)}$ points out that there is only one electromotive force series, but many galvanic series are possible because the relative responses of metals differ from one environment to another.

The successful performance of aluminum fins on copper. alloy tubes in many dry coolers is significant evidence that galvanic series must be interpreted carefully. In installations where the galvanic contact is dry most of the plant life, corrosion is not significant over exposures up to $\sim 25$ years. On the other hand, severe corrosion has arisen within 5 years when the couple is moist over a significant fraction of plant life.

Figure 31 illustrates the fact that multiple factors often interact to influence atmospheric corrosion. (82) Separate and combined influences of humidity, $\mathrm{SO}_{2}$ and particulates on mild steel corrosion are indicated in the figure. The contaminated environments indicate a "critical humidity" in the vicinity of $70-80 \%$, where corrosion rates markedly increase. The relatively potent interaction of soot, $\mathrm{SO}_{2}$ and humidity is particularly relevant to cooling tower siting and cleaning procedures in coal-fired plants. It is not to be implied that aluminum weathering is similar to that shown in Figure 31 for mild steel. Aluminum does not behave in the manner illustrated by Figure 31, as will be shown subsequently.

Figure 32 illustrates another important atmospheric corrosion consideration, namely, seasonal changes in contaminants, which may influence 
TABLE 24.

ELECTRODE POTENTIAL OF VARIOUS METALS AND ALLOYS IN CHLORIDE-PEROXIDE SOLUTION(81)

Metal or alloy ${ }^{a}$

Magnesium . . . . . . . . . . . . . . .

Zinc . . . . . . . . . . .......

$\mathrm{B} 605$. . . . . . . . . . . . . . .

A612 . . . . . . . . . . . . . . .

7072, Alclad 3003, Alclad 6061, Alclad 7075 .

X7005-T6, -T63; 7039-T6, -T63

220-T4

$5056,7079-16,5456,5083,214,218$

5154,5454

5052,5086

$3004,1060,5050,7075-\mathrm{T} 73$

$1100,3003,6751,6053,6061-16,6063$, Alclad

2014, Alclad 2024 . . . . . . . . . .

13, 43, cadmium . . . . . . . . . . .

7075-T6, 7178-T6..............

$356 \mathrm{T6}, 360$. . . . . . . . . . . .

2024-T81, 6061-T4 ............

355-T6 . . . . . . . . . . . .

2219-T6, $-\mathrm{T8}$

2014-T6, 750-T4

$108-\mathrm{F}$

$380-F, 319-F, 333-F$

195-T6 . . . •

B195-T6 . . . . . . . . . . . . . .

2014-T4, 2017-T4, 2024-T3, -T4 .......

2219-T3, -T4 . . . . . . . . . . . . .

Mild steel ..............
Potential, $V$ $0.1 \mathrm{~N}$ calomel scale $\mathrm{e}^{\mathrm{b}}$

$-1.73$

$-1.10$

$-1.06$

$-0.99$

$-0.96$

-0.93 to -0.96

$-0.92$

$-0.87$

$-0.86$

$-0.85$

$-0.84$

$-0.83$

$-0.82$

-0.81 to $-0.85^{C}$

$-0.81$

$-0.80$

$-0.79$

-0.79 to -0.82

$-0.78$

$-0.77$

$-0.75$

$-0.73$

$-0.72$

-0.68 to $-0.70^{c}$

-0.63 to $-0.65^{c}$

$-0.58$ 


\section{TABLE 24. (continued)}

\section{ELECTRODE POTENTIAL OF VARIOUS METALS AND ALLOYS}

IN CHLORIDE-PEROXIDE SOLUTION

\begin{tabular}{|c|c|}
\hline Metal or alloy ${ }^{a}$. & $\begin{array}{c}\text { Potential, } \mathrm{V} \\
0.1 \mathrm{~N} \text { calomel } \mathrm{scale} \\
\end{array}$ \\
\hline Lead . . . . . . . . . . . . . . . & -0.55 \\
\hline . . . . . . . & -0.49 \\
\hline Copper . . . . . . . . . . . & -0.20 \\
\hline ................. & -0.18 \\
\hline Stainless steel (series 300 , typè 430 ). & -0.09 \\
\hline Silver . . . . . . . . . . & -0.08 \\
\hline Nicke1 . . . . . . . . . . . . & -0.07 \\
\hline Chromium . ... . . . . . . . . . & -0.40 to +0.18 \\
\hline
\end{tabular}
a) The potential of all tempers is the same unless temper is designated.
b) Measured in an aqueous solution of $53 \mathrm{~g}$ per liter $\mathrm{NaCl}+3$ g per liter $\mathrm{H}_{2} \mathrm{O}_{2}$ at $25 \mathrm{C}$; values are very sensitive to peroxide concentration.

c) The potcntial varics with quenching rate. 
TEST TIME IN DAYS

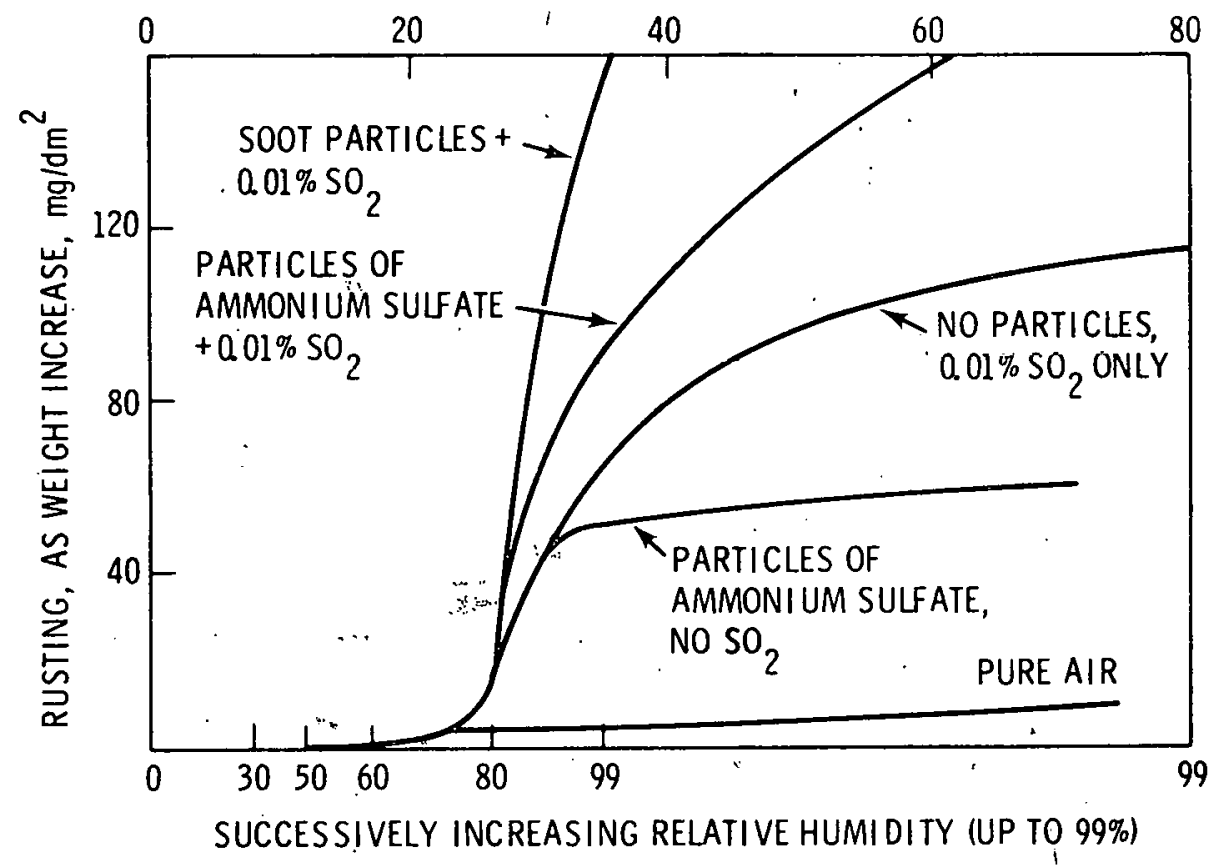

FIGURE 31. Effect of Increasing Humidity on Mild Steel: with Various Atmospheric Contaminants (82)

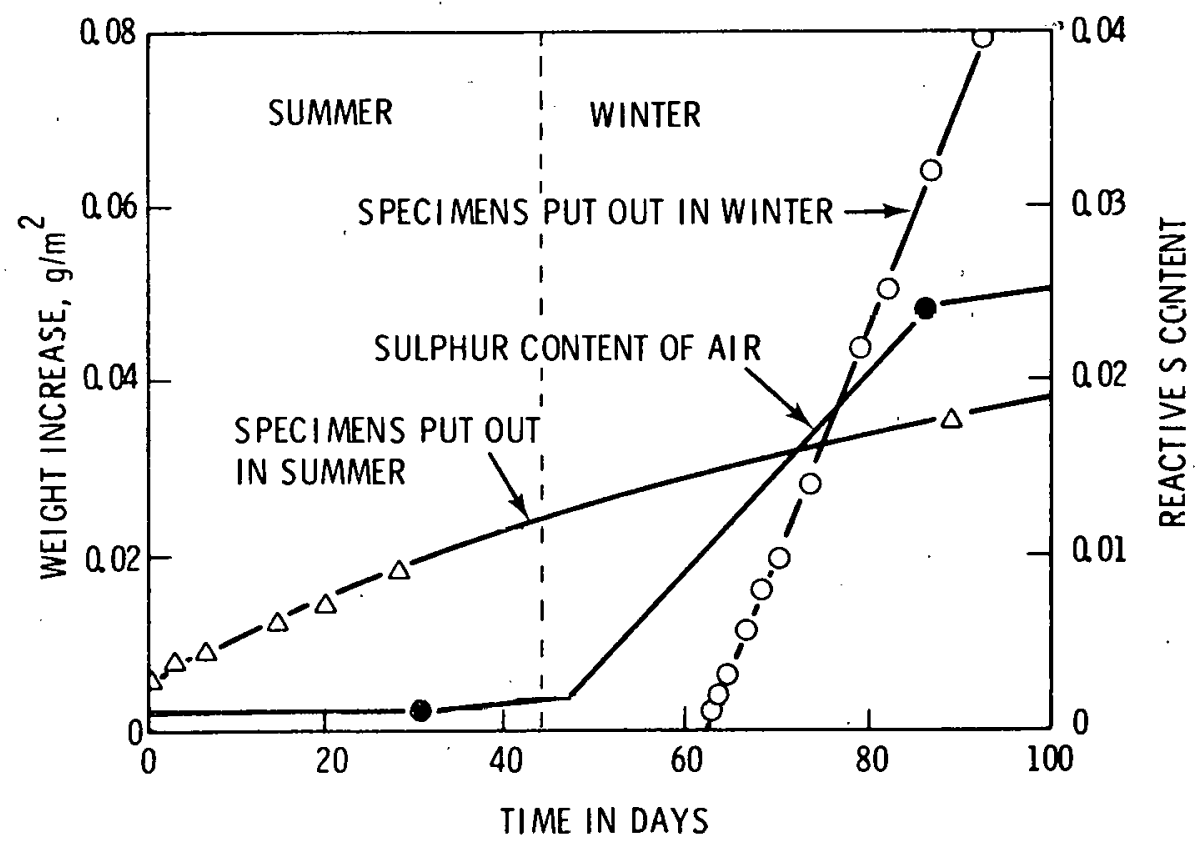

FIGURE 32. Effect of Initial Exposure Conditions 
corrosion. (82) The data, illustrated for copper, indicate a concomitant increase in corrosion with the wintertime rise in $\mathrm{SO}_{2}$ concentration under ambient conditions. Presumably, the summer specimens developed an oxide which was at least partially protective against sulfur species. The winter specimens did not have an opportunity to develop a protective film before exposure to the aggressive sulfur species. While it is not clear how broadly these results can be extrapolated to other materials, they suggest the prospect of optimum timing for installation of equipment, particularly in contaminated environments.

Of more general importance is the need to adequately protect equipment prior to and during installation. A cogent example of preinstallation corrosion arose at a gas pipeline compressor station, where a dry cooler was shipped and stored without a nitrogen cover gas or even adequate protection from ingress of moisture. During storage and installation, a substantial rust layer developed on the internal mild steel piping. The rust development went unnoticed. When the cooler was hooked up to the oil system of a large engine, substantial rust became suspended in the oil. It was necessary to remove the new system from service and chemically clean it to remove the rust. Similar occurrences in other segments of the power equipment industry clearly indicate the need for identification and enforcement of procedures which protect equipment during prestartup and layup phases. Proper protection requires approprtate cognizance by the fabricator, installer and plant operator.

The following sections will address specific atmospheric corrosion characteristics of alloys of aluminum, fron and copper, arld ydlvallized materials.

\subsubsection{Aluminum Alloys}

Aluminum is one of the two major finned tube materials now installed in operating dry-cooled power plants and is the major fin material for low temperature $\left(45-65^{\circ} \mathrm{C}\right)$ dry cooler applications.

Nominal compositions for aluminum alloys used in atmospheric service were previously given in Table 14. The alloys most commonly used for finned tube applications are 6061 or 6063 (extruded) and 1100 (plate, tension wound, or soldered). 


\subsubsection{Atmospheric Corrosion Data -- Aluminum Alloys}

Figure 33 presents corrosion data for aluminum alloys operating at ambient metal temperatures as obtained at industrial and marine sites for exposure times up to 30 years. (83) strength (LOTS) and maximum and average local penetration. Data on loss of tensile strength (LOTS) were generated on thin pre-machined specimens. The numerical values would be much lower for thicker specimens. The data for the inland industrial site (Figure 33 ) is an excellent example of the selflimiting tendency for the atmospheric corrosion of aluminum alloys. The greatest. corrosion occurred during the first 2 years, with a low subsequent corrosion rate out to the limit of the observations. Figure 34 , for the industrial sites, shows that aluminum corrosion response is sensitive to environmental conditions. (83) Based on the LOTS parameter, the self-limiting tendency is evident for the Rochester site; but not for the Altoona site, where a relatively high near-linear rate is evident. The design significance of such data is a function of the section size and application of the component.

Figure 35 presents penetration data for a marine site (Pt. Judith) for the same alloys shown in previous figures. ${ }^{(83)}$ Superimposing Figures 33 and 35 reveals that after about 1 year, both the average and the maximum penetration curves for the marine site are persistently greater than those for the inland industrial site. After 30 years, the disparity in both measures of corrosion is roughly a factor of two less in favor of the industrial site. Figure 36 presents LOTS data for various marine sites, including La Jolla, which is considered to be an extremum location with respect to marine environment corrosion. (83) Again, the data demonstrate that, like industrial atmospheres, the "marine" category allows a wide variation in local conditions (wind, salt deposition, periodic wetting, rain cleaning, etc.) It is interesting that the data for the extreme marine site (La Jolla) and the extreme industrial site (Altoona) are virtually superimposable on the basis of the LOTS parameter, at least to 20 years of exposure. 


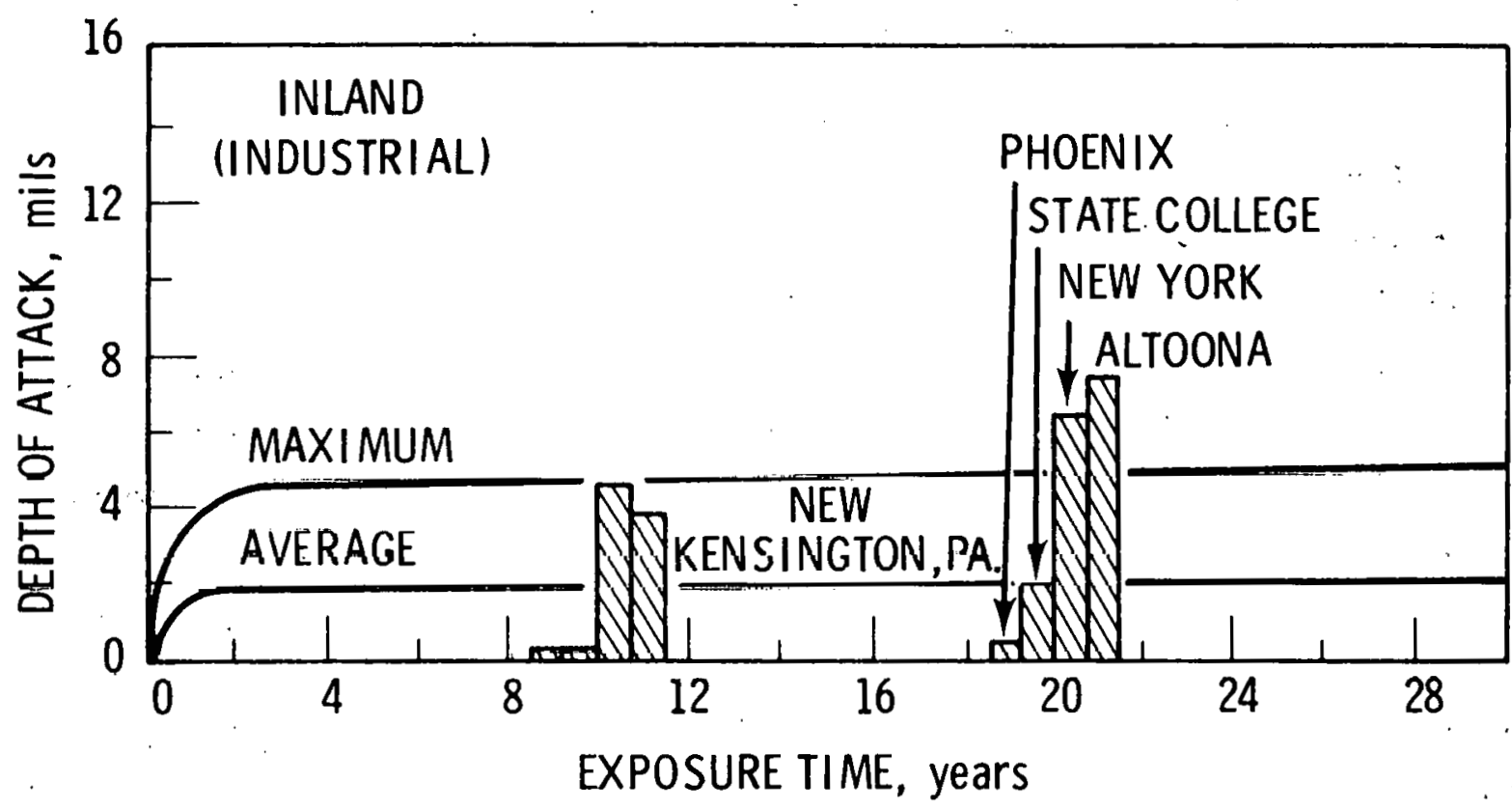

FIGURE 33. Maximum Depths of Attack (Vertical Bars) of Aluminum Alloy 3003-H74 at 10 and 20 Year Periods Superimposed on Curves Obtained on Related Alloys $(1100,3003,3004)$ Exposed at New Kensington. Values for Phoenix and State College (NonIndustrial Environments) are Shown for Comparison. (83)

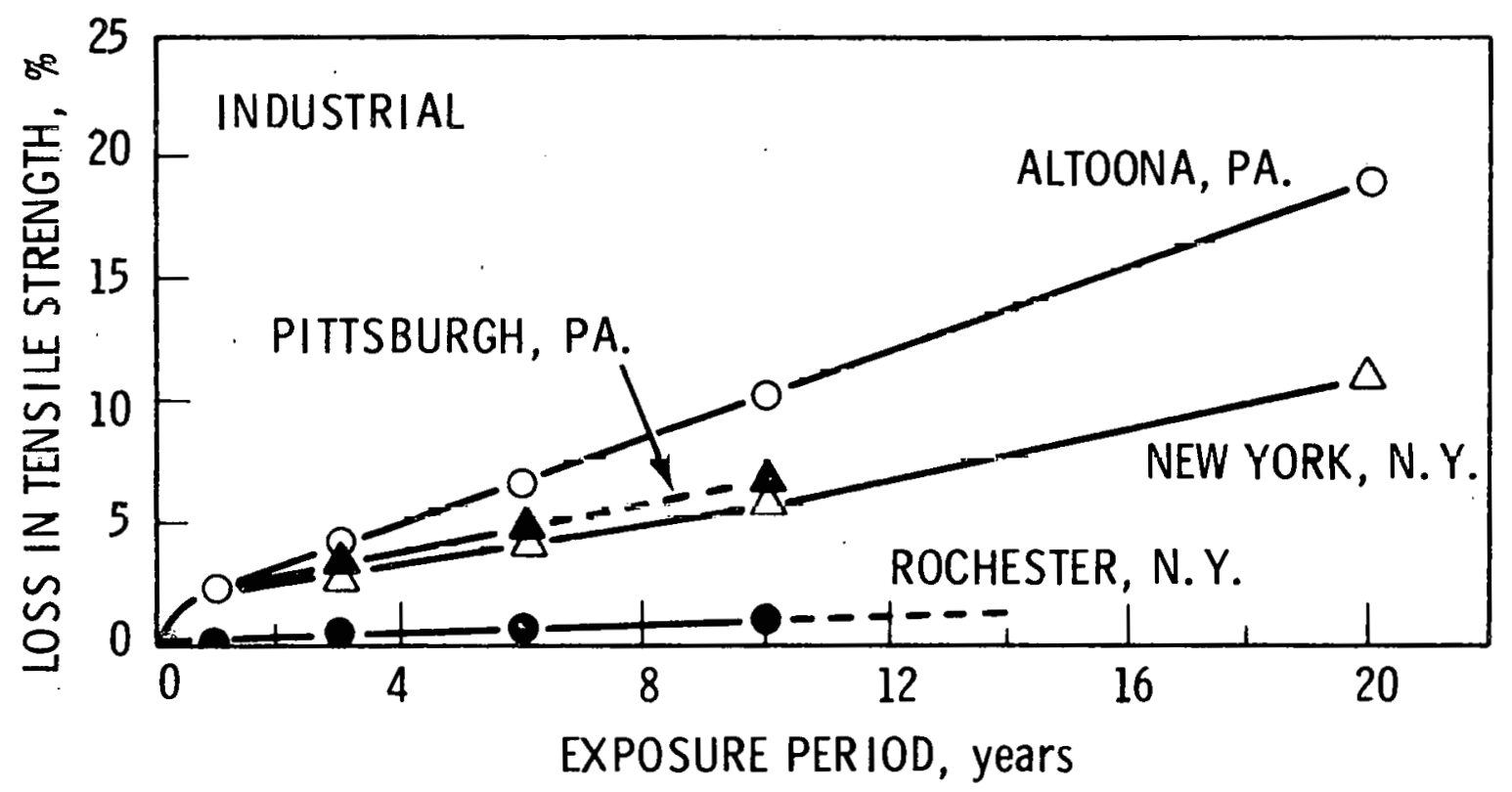

FIGURE 34. Rate of Weathering of Aluminum Alloy 3003-H74 in Industrial Environments as Measured by Loss of Tensile Strength.(83) 


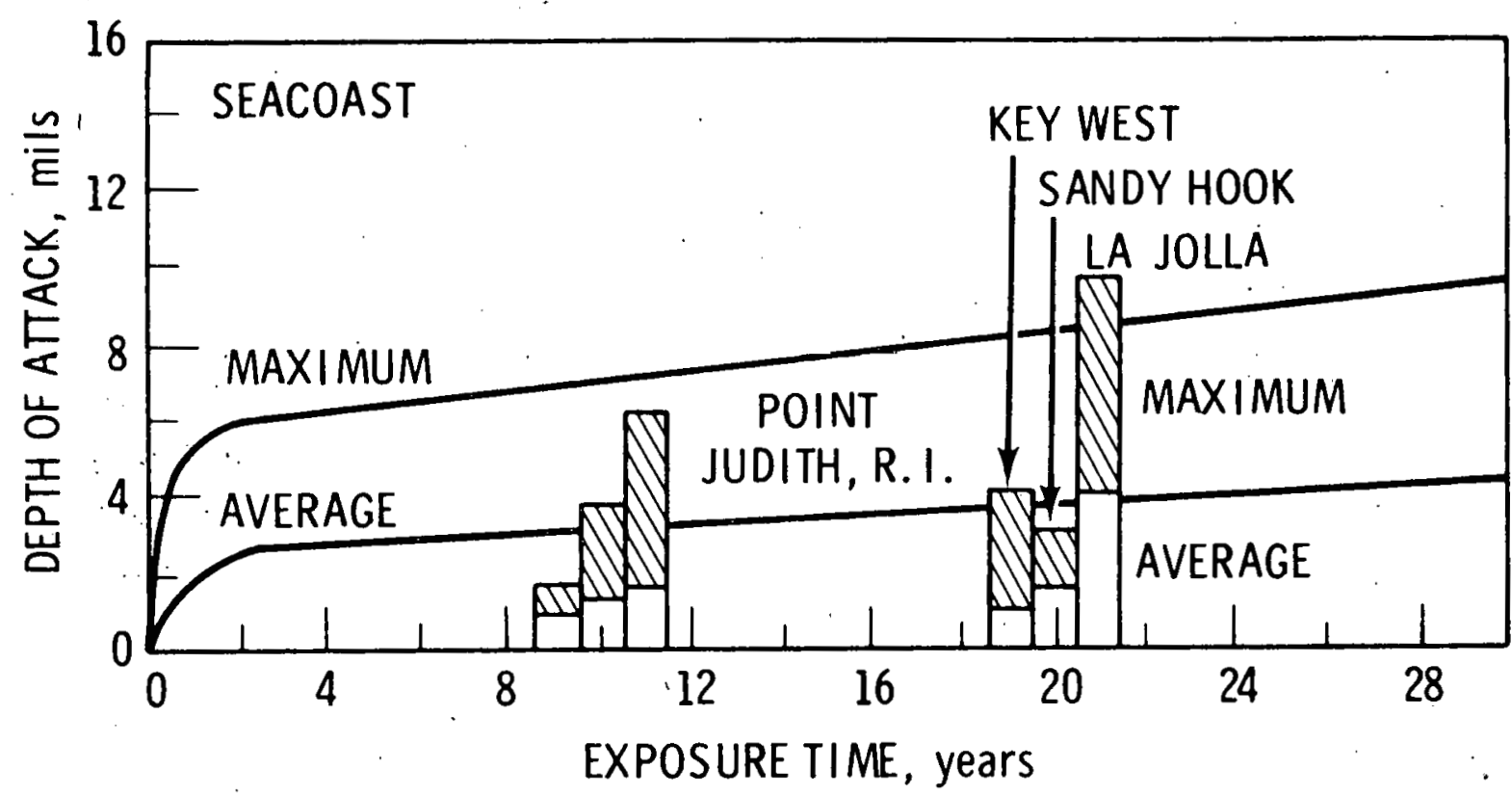

FIGURE 35. Measured Depths of Attack of Aluminum Alloy 3003-H14 at 10 and 20 Year Periods Superimposed on Curves Obtained on Related Alloys $(1100,3003,3004)$ Exposed at Point Judith, R. I. (83)

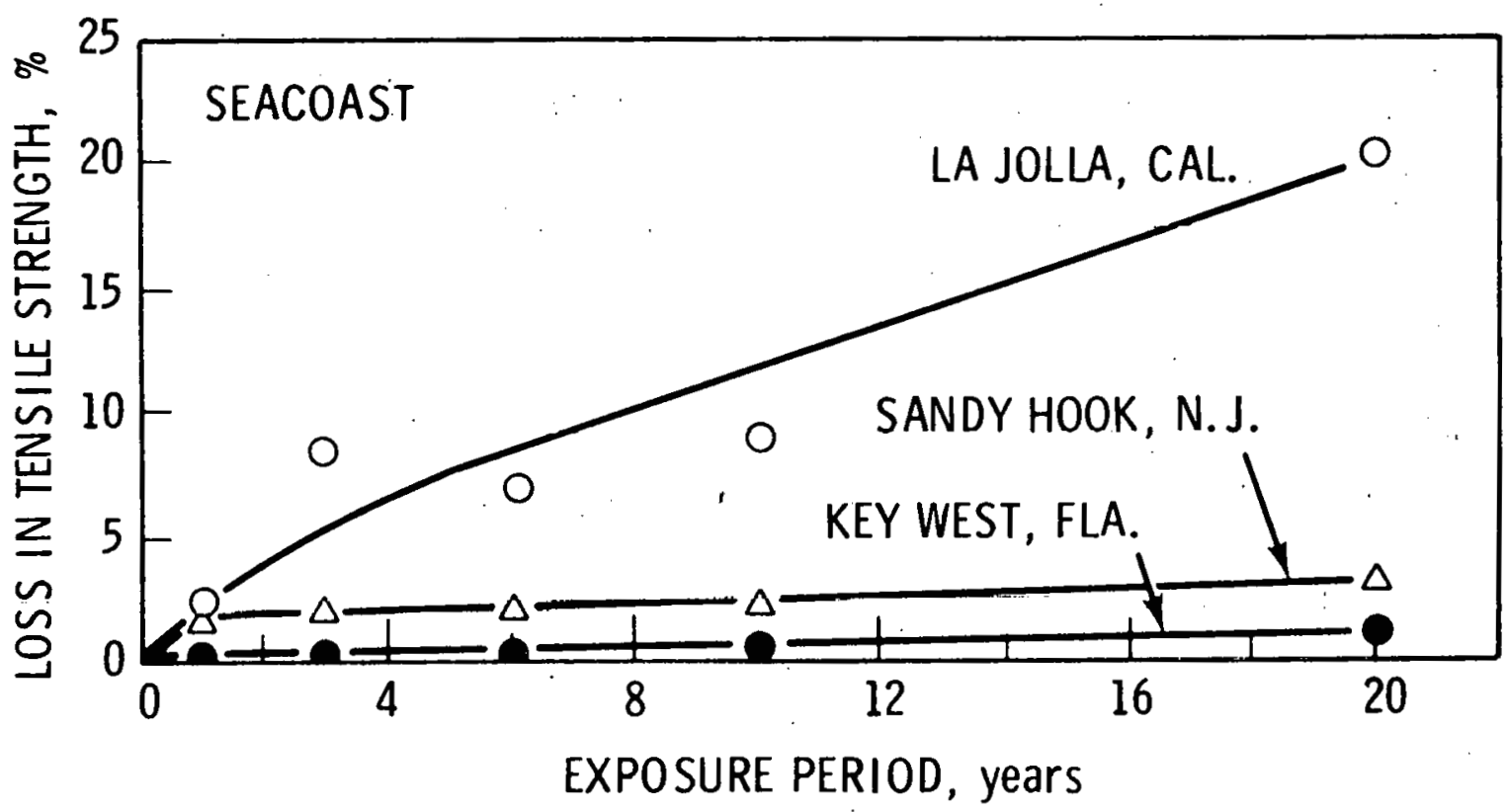

FIGURE 36. Rate of Weathering of Aluminum Alloy 3003-H14 in Seacoast Envirgnments as Measured by Loss of Tensile Strength. (83) 
Aluminum corrosion under average rural conditions is minimal. Figure 33 indicates this by the data for the Phoenix and State College sites added to the plot at the 10 and 20 year points. (83) The low rates at rural sites is borne out by our own observations on aluminum fins from several gas compressor engine coolers.

As indicated in Section 1, preliminary data from aluminum fins collected from dry coolers at several locations in the U.S. indicate mild corrosion at most sites, including 18 years adjacent to the Columbia River and 16 years 1.5 miles from the Gulf of Mexico. Severe intergranular attack occurred on aluminum fins exposed at a marine site where certain sulfur compounds were also a contaminant. The conclusion from thesc obscrvations and the foregoing discussion is that aluminum functions satisfactorily in most ambient atmospheric and dry cooling tower exposures. The few environments where aluminum does not function satisfactorily, such as some seacosts or alongside a chemically polluting plant, need to be recognized and avoided.

Alcad aluminum provides protection against deep pitting that might lead to perforation in environments where electrochemical rather than direct chemical attack is the mechanism. Alcad alloys that might be considered for air cooler construction normally are composites of a core alloy chosen for mechanical or other characteristics and a cladding alloy normally containing $1 \%$ zinc with the balance aluminum. The cladding alloy has a solution potential electronegative to that of the core alloy and under conditions where both core and cladding are exposed, the cladding provides cathodic protection.

Organic coatings also have been effective in extending aluminum life under some aggressive conditions, but with penalties on cost and heat transfer. The most desirable solution for large power plants appears to be to predetermine the suitability of uncoated aluminum for a given site and el iminate sites where aluminum cannot function satisfactorily on its own merits.

It is appropriate to consider the significance of the data in Figures 33 to 36 to dry cooling technology. Fin cross sections of 0.2 to $0.3 \mathrm{~mm}(0.01$ to 
0.015 in.) are typical. The data for average penetrations seem most relevant to fin integrity, since a few localized pits will not interfere substantially with fin integrity or heat transfer. Considering that corrosion proceeds from both surfaces, the data for New Kensington indicate that the average corrosion penetration would be $2 \mathrm{mils}$ per surface, or a total of $4 \mathrm{mils}$ on a 10 to $15 \mathrm{mil}$ cross section. However, the indicated penetra-... tions apply to aluminum exposed at ambient temperatures. Under power plant operating conditions, the corrosion rates will be much lower than those indicated in Figures 32 and 34 except when it fogs, rains or snows.

The loss of tensile strength will also be correspondingly lower than the values in Figures 33 and 35 . Because the fins are not loadbearing, LOTS is not a critical factor if the fins are adequately protected from hail by screens or louvers and are not subjected to human weight during maintenance.

The importance of quantifying corrosion data under dry-cooled conditions at a variety of sites is most strongly illustrated by data for the La Jolla seabeach site, where the average penetration in the corrosion sites measured appears to project to 25 mils after 30 years, suggesting that a $10 \mathrm{mil}$ fin thickness would be essentially consumed. However, some of the original surface remains unaffected for many years. Under dry cooled conditions the rate may be substantially lower, but direct measurements would be necessary to confirm this.

It is important to note that data reported $(86,86 a)$ from another West Coast marine site (Point Reyes, California) indicate an average calculated corrosion rate, based on weight loss data, of 0.0035 mpy on 3004-H34 aluminum. Projecting this rate linearly for 30 years indicates a reduction in fin cross section of only $0.2 \mathrm{mil}$. While direct comparison with the LaJolla data is not valid, it does show that generalizations of atmospheric corrosion are not consistent, even within a single category, such as marine corrosion. The difference between various seacoast areas, as shown in Figure 36, can be great since they are influenced by the direction of the prevailing winds. Also, labelling an area as "industrial" is a gross generalization since air quality will vary widely from one industrial area to another and with time. 


\subsubsection{Corrosion Mechanisms}

Atmospheric corrosion of aluminum al loys proceeds by attack at local anodic sites, which builds up a shallow, self-limiting oxide. The attack then develops at other anodic sites, gradually progressing over the entire surface, finally reaching a low steady-state rate. The low rate generally is reached after 2 to 3 years and continues unless the protective character of the oxide is disturbed. Chloride ion is a common depassivator of aluminum. ${ }^{(84)}$ Figure 37 indicates the relative effectiveness of halide species in lowering the pitting potential (the potential at which a rapid increase in corrosion occurs by a pitting mechanisism). Chlorlde was musl effective in reducing the pitting potential. (85)

The $\mathrm{pH}$ of the electrolyte is an important factor in aluminum corrosion as indicated in Section 3 (Figure 12, p. 41). Highiy basic or highly acidic solutions favor breakdown of passivation. However, the response of al uminum corrosion to $\mathrm{pH}$ depends strongly on the species which contribute to changes in $\mathrm{pH}$, as shown in Figure 12.

Reference 83 includes weathering data for five of the alloys from Table 14, exposed at 15 sites. The data indicate no significant differences in corrosion rate as a function of alloy composition.

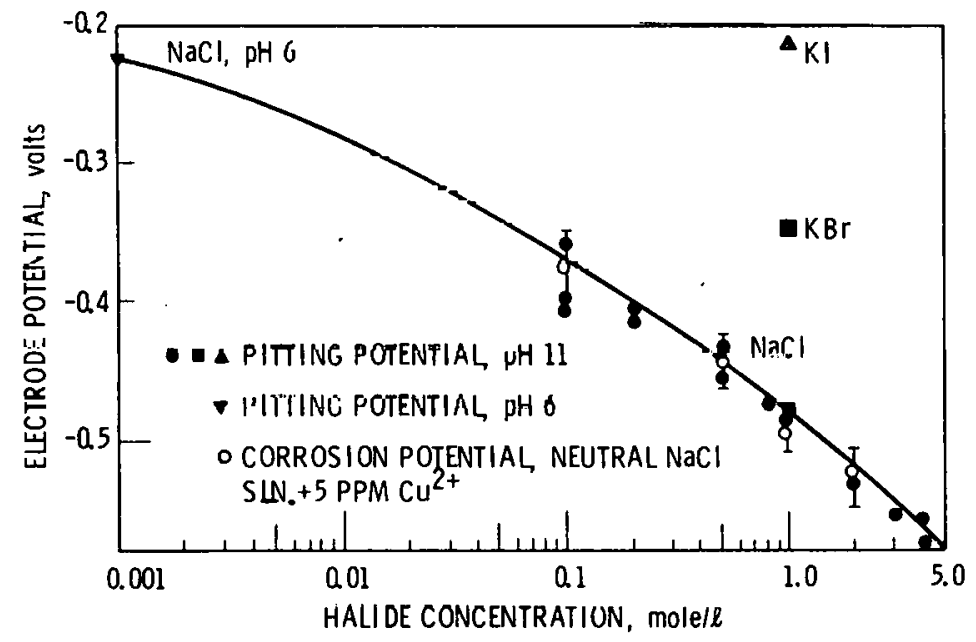

FIGURE 37. Breakthrough Potential of Aluminum (99.99\%) in Different Halide Solutions, and Open Circuit Corrosion Potential in Chloride Solutions Containing $5 \mathrm{ppm} \mathrm{Cu}^{++(85)}$ 
Stress corrosion cracking tendency increases with alloy complexity, al though there are interactions among additive elements which also tend to decrease the stress corrosion cracking tendency. According to Speidel, (87) the aluminum alloys 7079-T6, 7075-T6 and 2024-T3 account for more than $90 \%$ of the reported stress corrosion cracking incidents on aluminum alloys from 1960 to 1970. Thus, the alloys used in dry cooling tower service are not susceptible to stress corrosion cracking. Stress corrosion cracking has not appeared to be a significant problem in air-cooled equipment.

Hirschfelder ${ }^{(6)}$ expresses the fear that extruded aluminum fins are especially susceptible to corrosion because of the plastic deformation to which they are subjected in the extrusion process. This view is also expressed in a recent paper by Von Cleve. ${ }^{(88)}$ This may be true of aluminum alloys with a magnesium content of more than $3 \%$ ( $5 \times x \times$ series); increased severity of cold working, temperature, and time cause grain boundary precipitation and increased susceptibility to exfoliation, intergranular attack and stress corrosion cracking. However, aluminum alloy 6063 is the alloy most widely used for extruded fins, and it is not susceptible to increased corrosion as a result of fabrication cold working. (89) Tubes with extruded aluminum fins are widely used in petroleum refineries, natural gas processing plants and chemical plants, and no problems of this nature have been reported in 25 years of experience. (90)

Aluminum alloys are susceptible to crevice attack in some environments. Crevices arc a common feature in certaill dir cooler designs, which operate satisfactorily if the crevice remains dry through most of the plant life.

Intergranular attack of aluminum alloys used in dry cooling tower construction generally has not been a problem. However, in a case cited earlier, intergranular attack occurred on an 1100 series alloy exposed to a marine environment contaminated with sulfur compounds.

\subsubsection{Iron-Base Alloys}

Four classes of iron-base materials find extensive industrial use involving atmospheric exposures: ${ }^{(91)}$. 
- Mild Steel - not recommended in the uncoated condition for long term atmospheric exposure, but does serve satisfactorily in most environments when paints and coatings are properly maintained.

- Weathering Steels - has generally good resistance to atmospheric corrosion with uncoated surfaces. Is not recommended for severe marine environments. However, exposure results at Kure Beach $(250 \mathrm{~m}$ lot) show that weathering steels are superior to mild steel. (37) The material costs $20-30 \%$ more than carbon steel, but is stronger, requiring less material, resulting in lower shipping costs.

- Aluminized Steel - Aluminumi coatings approximately $25 \mu \mathrm{m}(0.001 \mathrm{ln}$. and $50 \mu \mathrm{m}(0.002 \mathrm{in.})$ thick are applied to steels by several methods. Presently only the heavier coating is recommended for atmospheric exposure. The steel has markedly better resistance to atmospheric corrosion than galvanized steel in most environments due to both blanket coverage and cathodic protection, although blanket coverage probably plays the greater role. ${ }^{(92)}$ This excellent atmospheric corrosion resistance of aluminum-coated steel compared with that of galvanized steel is attributed to the superior corrosion resistance of al uminum compared with zinc. (93)

- Ferritic Steels - Type 409 steel performs well in essentially al1 atmospheric environments. The cost is about double that of galvanized steet.

Galvanized materials comprise a fifth category which will be addressed in a separate section.

\section{Steel Compositions}

The nominal compositions of carbon or mild steel are:

\begin{tabular}{|c|c|c|c|c|c|}
\hline & c & $\mathrm{Mn}$ & $\mathrm{P}$ & $\mathrm{s}$ & Si \\
\hline & $06 / 0$ & $0.27 / 0.63$ & $0.048 \operatorname{Max}$ & $0.058 \operatorname{Max}$ & 0.2 \\
\hline & $0.35 \mathrm{Max}$ & $0.29 / 1.06$ & $0.048 \operatorname{Max}$ & 0.058 Max & $0.1 \mathrm{Min}$ \\
\hline
\end{tabular}

Compositions of several weathering steels are given in Table 25. Aluminized steel comprises a mild steel substrate and an aluminum-silicon alloy coating. (See Reference 91 for a description of fabrication.) 
The ferritic (Type 409) steel composition is:

$$
\frac{\mathrm{C}}{0.08 \operatorname{Max}} \frac{\mathrm{Mn}}{1.0 \operatorname{Max}} \frac{\mathrm{Si}}{1.0 \operatorname{Max}} \frac{\mathrm{Cr}}{10.5 / 11.5} \frac{\text { Other }}{\mathrm{T}_{\mathrm{i}} 6 \times \mathrm{CMin}}
$$

The $18 \mathrm{Cr}-8 \mathrm{Ni}$ austenitic stainless steels are candidates for some high- 1 temperature dry cooler applications, but are not likely candidate for large-scale usage in dry cooling towers for economic reasons.

\subsubsection{Corrosion Behavior-Steels}

Weathering rates are compared in Figure 38 for a carbon steel, a structural copper steel and a weathering steel. After 20 years in an industrial environment, the corrosion penetration is lower by a factor of six for the weathering steel, and the steady state corrosion rate is substantially. lower than the rate for carbon steel. For a study of the corrosion synergisms among the alloy constituents for low-alloy steels see Legault and Preban. (94)

As discussed earlier, periodic wetting is generally a more harmful corrosion situation than continuous immersion. It is interesting that under continuous immersion the weathering steels exhibit no significant advantage over ordinary carbon steels. The desired compact, protective, corrosion layer apparently requires alternate wetting and drying to fully develop.

The performance of several steels within the weathering steel family, under various severe industrial environments is shown in Reference 83 . For the condition of maximum exposure ( 2 years), the corrosion differential between the carbon steel and the weathering steels is not large (factors of two to four). Obviously, the alloying limits of the low alloy steels do not provide adequate resistance against aggressive environments which are outside the usual chemistry limits attributed to "atmospheric" exposure. The characteristic protective coating of weathering steels is affected by various industrial contaminants, particularly $\mathrm{SO}_{2}$, and the margin of advantage of. weathering steels over ordinary carbon steels may disappear under some cirrumstances. For exposure conditions requiring the stabilizing 
TABLE 25. ASTM Chemical Requirements (ASTM A-588) for WeatheringType Steels $(83)$ *

\begin{tabular}{|c|c|c|c|c|c|c|c|c|c|}
\hline \multirow[b]{2}{*}{ Element } & \multicolumn{9}{|c|}{ Composition, percent } \\
\hline & Grade $A$ & Grade B & Grade C & Grade D & Grade E & Grade F & Grade G & Grade $\mathrm{H}$ & Grade J \\
\hline Carbon & $0.10-0.19$ & $0.20^{(a)}$ & $0.15 \max$ & $0.10-0.20$ & $0.15 \max$ & $0.10-0.20$ & $0.20 \max$ & $0.20 \max x$ & $0.20 \max$ \\
\hline Manganese & $0.90-1.25$ & $0.75-1.25$ & $0.80-1.35$ & $0.75-1.25$ & $1.20 \max$ & $0.50-1.00$ & $1.20 \max$ & $1.25 \max$ & $0.60-1.00$ \\
\hline Phosphorus & $0.04 \max$ & $0.04 \max$ & $0.04 \max$ & $0.04 \max$ & $0.04 \max$ & $0.04 \max$ & $0.04 \max$ & $0.035 \max$ & $0.04 \max$ \\
\hline Sulfur & $0.05 \max$ & $0.05 \max$ & $0.05 \max$ & $0.05 \max$ & $0.05 \max$ & $0.05 \max$ & $0.05 \max$ & $0.040 \max$ & $0.05 \max$ \\
\hline Silicon & $0.15-0.30$ & $0.15-0.30$ & $0.15-0.30$ & $0.50-0.90$ & $0.15-0.30$ & $0.30 \max$ & $0.25-0.70$ & $0.25-0,75$ & $0.30-0.50$ \\
\hline Nickel & -- & $0.25=0.50$ & $0.25-0.50$ & -- & $0.75-1.25$ & $0.40-1.10$ & $0.80 \operatorname{miax}$ & $0.30-0.60$ & $0.50-0.70$ \\
\hline Chromium & $0.40-0.65$ & $.0 .40-0.70$ & $0.30-0.50$ & $0.50=0.75$ & -- & 0.30 max & $0.50-1.00$ & $0.10-0.25$ & -- \\
\hline molybdenum & -- & -- & -- & -- & $0.10-0.2 B$ & $0.10-0.20$ & $0.10 \max$ & $0.15 \max$ & -- \\
\hline Copper & $0.25-0.40$ & $0.20-0.40$ & $0.20-0.50$ & $0.30 \max$ & $0.50-0.80$ & $0.30-1.00$ & $0.30-0.50$ & $0.20-0.35$ & $0.30 \min$ \\
\hline Vanadium & $0.02-0.10$ & $0.01 \cdot 0.10$ & $0.01 \cdots 0.10$ & -- & $0.05 \max$ & $0.01-0.10$ & $=$ & $0.02-0,10$ & -- \\
\hline onium & -- & -- & -- & $0.05-0.15$ & -- & -- & -- & -- & -- \\
\hline Col umbium & -- & -- & -- & $0.04 \max$ & -- & -- & -. & -- & -- \\
\hline Titanium & -- & -- & -- & -- & -- & -- & $0.07 \max$ & $0.005-0.030$ & $0.03-0.05$ \\
\hline
\end{tabular}

(a) Maximum.

Many other weathering steels are also available as proprietary grades under ASTM A-242.

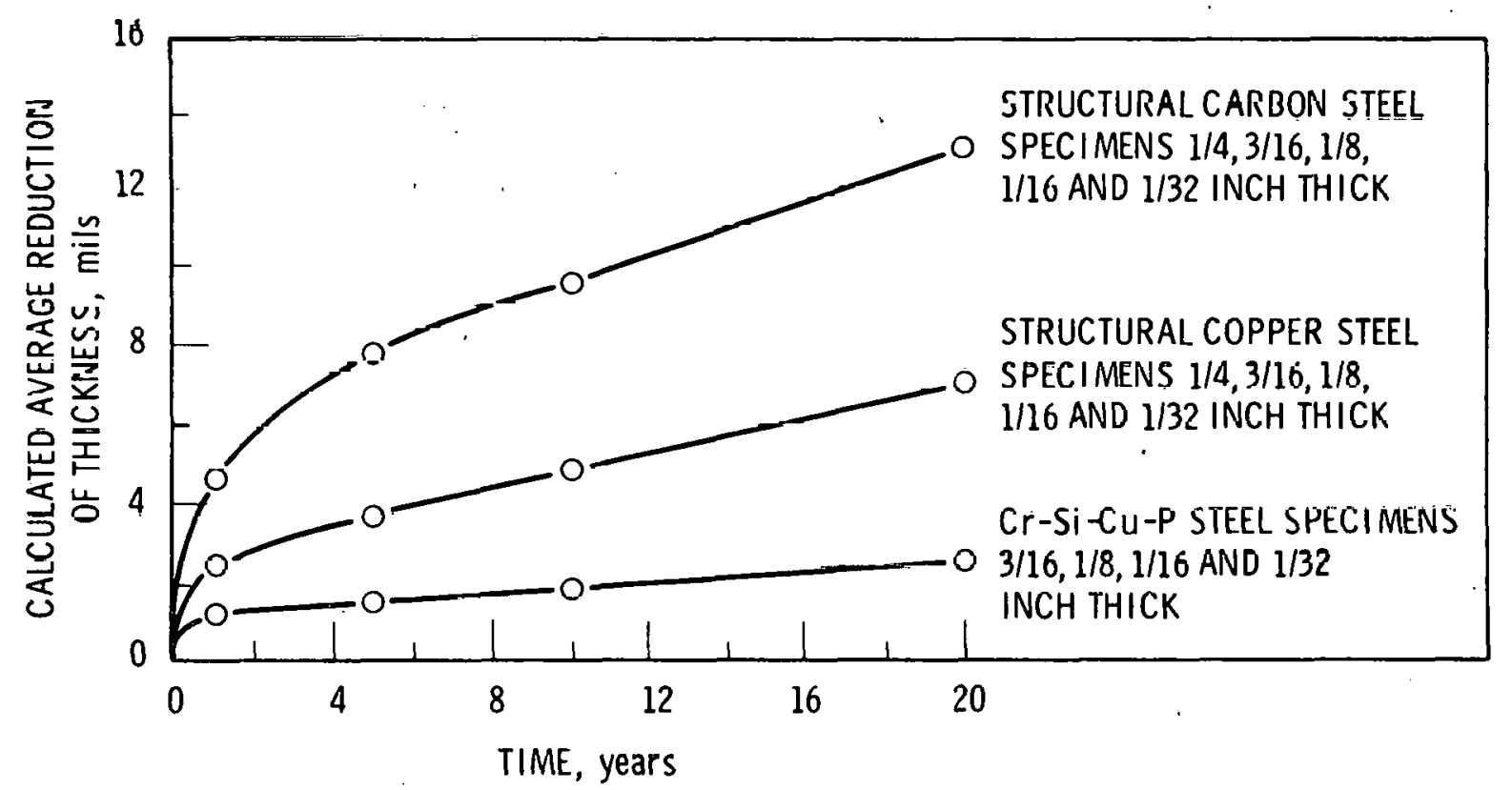

FIGURE 38. Comparative Corrosion of Steels of Varying Thicknesses, Industrial Atmosphere, Kearney, $\mathrm{NJ}(83)$ 
assistance of various coatings for either type of steel, obviously the higher cost weathering steels would be at a disadvantage.

Based on extensive testing of a large number. of iron alloys, under a wide. variety of industrial, marine and rural environments, by a number of workers, Rozenfeld ${ }^{(78)}$ summarizes the 12 best steels as shown in Table 26. The most effective major alloy elements appear to be copper, chromium, phosphorus, nickel, aluminum and beryllium. Manganese appears to be particularly beneficial in marine enivronments. Specific major alloy combinations which have yielded significant improvement in atmospheric exposures are: Cu-P-Cr-Si, and $\mathrm{Cr}-\mathrm{Ni}-\mathrm{Mo}$, iron-base alloys.

The relative corrosion rates of aluminized steels are compared to carbon steel in Table 27, showing à distinct advantage for steel coated. with the Al-Si alloy. (93) Table 28 compares atmospheric corrosion rates for aluminized and galvanized coatings in three atmospheres, consistently indicating an advantage for the aluminized steels.

\subsubsection{Corrosion Mechanisms - Steels}

Pure iron and iron base alloys up to the approximate alloy level represented by the weathering steels must be classified as reactive materials, subject to all of the atmospheric corrosion factors discussed earlier. Metallurgically, the iron base alloys afford as many, or more, possibilities for physical-chemical dissimiliarities within the given alloy framework as any material. Also, there is in the iron-base system a corresponding array of corrosion possibilities with, or without, stress assistance.

For a given environment; alloying will affect changes in the corrosion products relative to pure iron. As noted above, complex alloys generally afford more comprehensive corrosion protection for the iron base alloys. The prediction of specific alluy effects, or alloy element corrosion synergism remains largely empirical. Figure 39 compares the corrosion product morphologies for weathering and mild steels. (83) The oxide on the weathering steel is continuous and compact, contrasting with the noncontiguous, nonprotective character of the oxide on mild sleel. 
TABLE 26. Composition and Corrosion: Rates of 12 Russian Weathering Steels(78)

Chemical Composition, Percent Corrosion

Cr $\mathrm{Cu}$ Ni Other Elements Index $\mu / \mathrm{yr}$

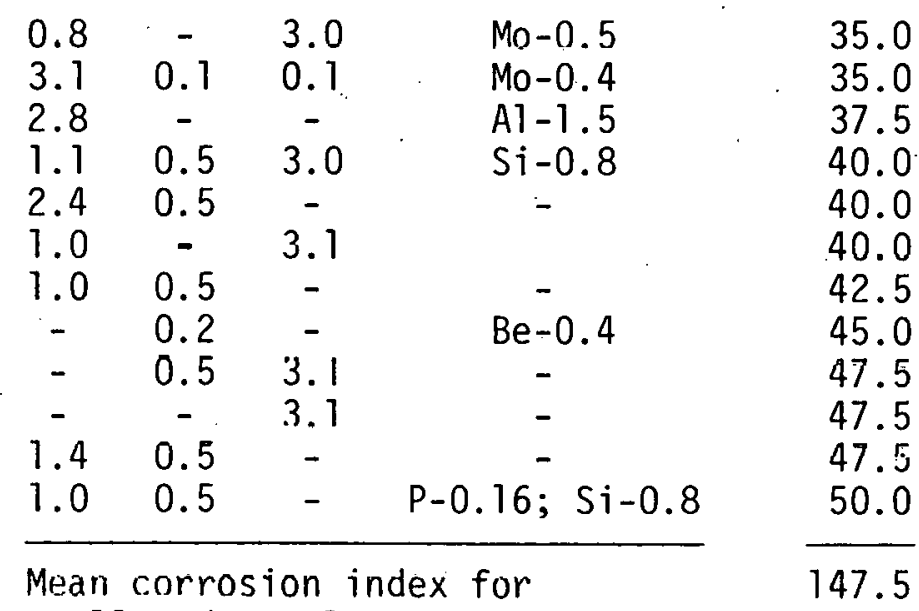

unalloyed steels

TABLE 27. Corrosion Performance of Aluminized Steel (yersus
Carbon Steel Alloy in Various Atmospheres $(93)$

\begin{tabular}{|c|c|c|c|c|}
\hline Material & $\begin{array}{c}\text { Time of } \\
\text { Exposure, } \\
\text { years }\end{array}$ & $\begin{array}{l}\text { Loss of W } \\
\text { Industrial } \\
\text { Atmosphere }\end{array}$ & $\begin{array}{l}\text { ight, grams } \\
\text { Semirural } \\
\text { Atmosphere }\end{array}$ & $\begin{array}{c}\text { per year* } \\
\text { Mdriirie } \\
\text { Atmosphere }\end{array}$ \\
\hline $\begin{array}{l}\text { Aluminum-Iron- } \\
\text { Silicon Alloy Coating }\end{array}$ & 8 & 0.118 & 0.079 & 0.254 \\
\hline $\begin{array}{l}\text { Aluminum-s111con } \\
\text { Alloy Coating }\end{array}$ & 2 & $0.07 ?$ & 0.031 & 0.016 \\
\hline Carbon Stee 1 & 7.5 & 6.6 & 4.1 & 5.6 \\
\hline
\end{tabular}

Iron base alloys are subject to pitting and intergranular corrosion. Factors controlling these types of corrosion are the same as discussed in connection with aluminum and in the introduction to this section. The $\mathrm{pH}$ influence on iron base alloys is indicated in Figure $40 .^{(32)}$ At high $\mathrm{pH}$ levels, the tendency of iron to form the soluble complex $\mathrm{HFeO}_{2}^{-}$leads 
TABLE 28. Corrosion Performance of Aluminum-Silicon Alloy Coatings

Versus Galvanized Coatings in Various Atmospheres(93)

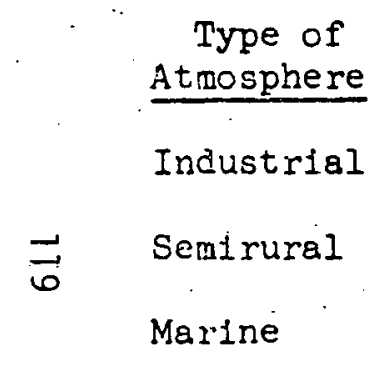

Type of

\section{Rate of Penetration, ${ }^{*}$ mils per year

Galvanized Aluminum-Silicon

Test S:te

Coating

0.159

0.027

0.074

0.016

0.061

0.010

$$
(800-\text { foot lot) }
$$

Rat10 of

Rates, $\mathrm{Zn} / \mathrm{Al}$

5.9

4.6

6.1

* Rate of penetration based on average welght losses of coating metal from 4- by 6-inch specimens exposed for 2 and 4 years. 


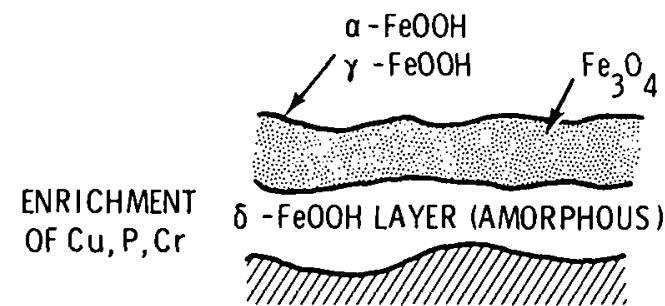

LOW ALLOY STEEL

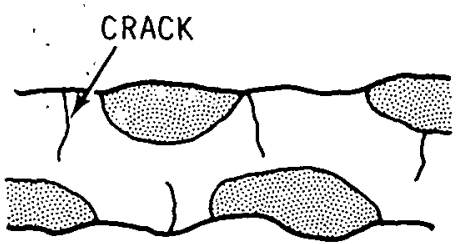

MILD STEEL

FIGURE 39. Schematic Representation of the Rust Layers on Steels After Exposure to the Atmosphere for Long Periods(03)

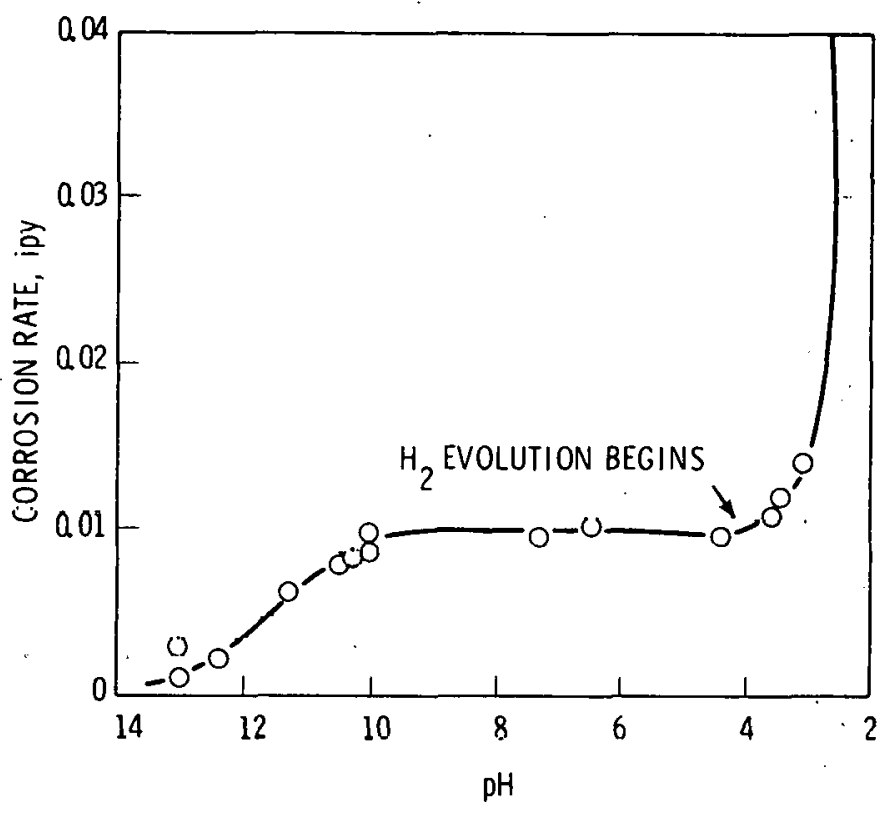

FIGURF 40. Effect of $\mathrm{pH}$ on Corrosion of Iron in Aerated Soft Water at Room Temperature (32).

to rapid attack. At low $\mathrm{pH}$ levels, the iron passivation is prevented by the acid solubility of its corrosion products.

Hydrogen liberated by electrochemical reduction at cathodic sites, or introduced by various other agents, may lead to the hydrogen embrittlement of steels, with the effect being particularly potent for high strength steels. The ferritic structure, although not close packed, cannot accommodate hydrogen which may permeate the structure. Under stress or low strain rate conditions, the ability of a ferritic structure to accommodate 
stress via plastic flow may be seriously affected by very low concentrations of hydrogen within the metal matrix, leading to brittle failure under stress.

Stress assisted corrosion (stress corrosion cracking, corrosion fatigue, etc.) also affects ferrous base alloys. Uhlig ${ }^{(95)}$ lists the following species as being particularly agressive to steels with regard to stress assisted corrosion:
Mild steel:
$\mathrm{NO}_{3}^{-}, \mathrm{OH}^{-}$
Medium strength steel: $\mathrm{HCN}^{-}$
High strength steel: $\quad \mathrm{H}_{2} \mathrm{O}, \mathrm{H}_{2}$

Although the statement is sometimes made that ferritic iron alloys are insensitive to chloride stress corrosion cracking, this ion has a potent effect on normally passivating films on iron base alloys and it certainly must have considerable potential for participation in the stress corrosion cracking process under appropriate metallurgical, stress, and environmental conditions.

As noted previously, the composition limits of low alloy steels do not allow comprehensive protection against corrosion. The cost effective position of these materials in dry cooling tower installations at aggressive sites will be strunly sensitive to the use of protective coatings which provide either barrier protection (paint, plastics, etc.) or barrier/ sacrificial (cathodic) protection, as in the case of zinc (galvanizing) or aluminum.

Correlations between steel corrosion and atmospheric pollutants have been published by Haynie and Upham. ${ }^{(96)}$

The mechanism for corrosion protection of aluminum layers does not appear, in most cases, to involve cathodic protection, as it does in the case of zinc layers. (93) Rather, it appears to involve formation of a protective oxide on the aluminum surface. However, because of its active 
position in galvanic series, aluminum will provide sacrificial protection to the steel substrate in aggressive environments which compromise the protective character of the oxide.

\subsubsection{Copper-Base Alloys}

The characteristic of copper and copper alloys which is most attractive to designers to heat exchangers is high thermal conductivity. The thermal conductivities for pure copper range from 224-218 Btu/hr/ft/ ${ }^{\circ} \mathrm{F}$, and pure aluminum from $117-119 \mathrm{Btu} / \mathrm{hr} / \mathrm{ft} /{ }^{\circ} \mathrm{F}$, over the temperature interval $32-212^{\circ} \mathrm{F}$; thus, the advantage for copper is about a factor of two. (97) Alloying of copper can quickly reduce this thermal conductivity advantage. For example, in the same units as above, the $k$ value for a $70 \mathrm{CU}$ - $30 \mathrm{Zn}$ brass ranges from 56-60 Btu/hr $/ \mathrm{ft} /{ }^{\circ} \mathrm{F}$. A necessary correlative characteristic of copper and copper alloys is the ability to develop stable corrosion product films in a wide variety of service environments, dry and aqueous. However, atmospheric corrosion compilations (Reference 86, Figure 30) indicate that copper is less corrosion resistant than aluminum on the basis of uniform corrosion. This ranking appears to be at some odds with the various galvanic series (e.g., Table 24), which consistently assign copper a substantially more noble (less active) position. The answer to this seeming contradiction is that, generally, the corrosion product film developed on aluminum is relatively more passivating than the patinas which develop on copper alloys. In many service situations, the margin of difference in corrosion response between aluminum and copper, while still favoring aluminum in most cases, would be acceptable for design purposes. However, the heat exchanger industry regards aluminum and galvanized materials as more cost effective than copper for fin fabrication in recent years. Copper alloys continue to be used for tube fabrication in some dry cooler applications.

\subsubsection{Atmospheric Corrosion Data - Copper Alloys}

Rozenfeld ${ }^{(78)}$ summarizes extensive atmospheric testing for a number of copper-base alloys under a variety of environmental conditions. Table 29 gives the compositions for the various alloy designations. Reference 78 gives a description of the various test environments, (coded by Roman 
TABLE 29. Copper Alloys Tested for Atmospheric Corrosion (78)

\begin{tabular}{|c|c|c|}
\hline Al loys & Designation (1) & Chemical Composition \\
\hline Electrolytic Copper & A. & $99.9 \% \mathrm{Cu}, 0.03 \% \mathrm{n}_{2}$ \\
\hline Phosphor copper & B & $99.9 \% \mathrm{Cu}, 0.02 \% \mathrm{P}^{2}$ \\
\hline Silicon bronze & C. & $95.8 \% \mathrm{Cu}, 3.1 \% \mathrm{Si} ; 1.1 \% \mathrm{Mn}$ \\
\hline Tin bronze & D & $99 \% \mathrm{Cu}, 8.0 \% \mathrm{Sn}, 0.1 \% \mathrm{P}$ \\
\hline Al bronze & $F$ & $92.0 \% \mathrm{Cu}, 8.0 \% \mathrm{Al}$ \\
\hline Brass (high strength) & K & $\begin{array}{l}60-68 \% \mathrm{Cu}, 20-24 \% \mathrm{Zn}, \\
2.5-5.0 \% \mathrm{Mn}, 3-7 \% \mathrm{Al}, \\
2-4 \% \mathrm{Fe}\end{array}$ \\
\hline Red bronze (Tompac) & I & $85 \% \mathrm{Cu}, 15 \% \mathrm{Zn}$ \\
\hline Brass, $70-30$ & M & $70 \% \mathrm{Cu}, 30 \% \mathrm{Zn}$ \\
\hline Brass-naval & $N$ & $70 \% \cdot \mathrm{Cu}, 29 \% \mathrm{Zn}, 1 \% \mathrm{Sn}$ \\
\hline$r-N i-Z n$ & $P$ & $75 \% \mathrm{Cu}, 20 \% \mathrm{Ni}, 5 \% \mathrm{Zn}$ \\
\hline Copper-Ni-Sn & $Q$ & $70 \% \mathrm{Cu}, 29 \% \mathrm{Ni}, 1 \% \mathrm{Sn}$ \\
\hline
\end{tabular}

numeral in Figures 41 and 42). The corrosion rates are compared in Figure 41. Figure 42 gives corresponding comparisons for loss of tensile strength. In general, copper and high copper alloys were more stable in industrial environments than the alloys with a lower copper content. The aluminum bronzes, $\mathrm{Cu}-\mathrm{Ni}, \mathrm{Cu}-\mathrm{Zn}$, and $\mathrm{Cu}-\mathrm{Ni}-\mathrm{Sn}$ alloys gave particularly good resistance to both marine and industrial environments. Considering only the marine atmospheres, the aluminum bronzes are exceptional, with the naval brasses $(N), \mathrm{Cu}-\mathrm{Ni}-\mathrm{Zn}(\mathrm{P})$, and $\mathrm{Cu}-\mathrm{Ni}-\mathrm{Sn}(\mathrm{P})$ alloys also very good. In rural atmospheres, the corrosion is minimal for all the materials tested. Electrolytic copper and phosphor copper give good stability in industrial atmospheres. The corrosion effect on strength loss is generally somewhat more severe than is predicted from the uniform penetration (Figure 42), suggesting that local penetration may be a significant problem with selected copper alloys in some environments. However, the tendency to local penetration is generally considerably less for copper alloys than for aluminum alioys.

Zinc-rich copper alloys are prone to dezincitication (selective leaching of zinc from the metal), which accounts for most of the strength loss noted for these alloys in the above compilation. Strength loss for the nickel 

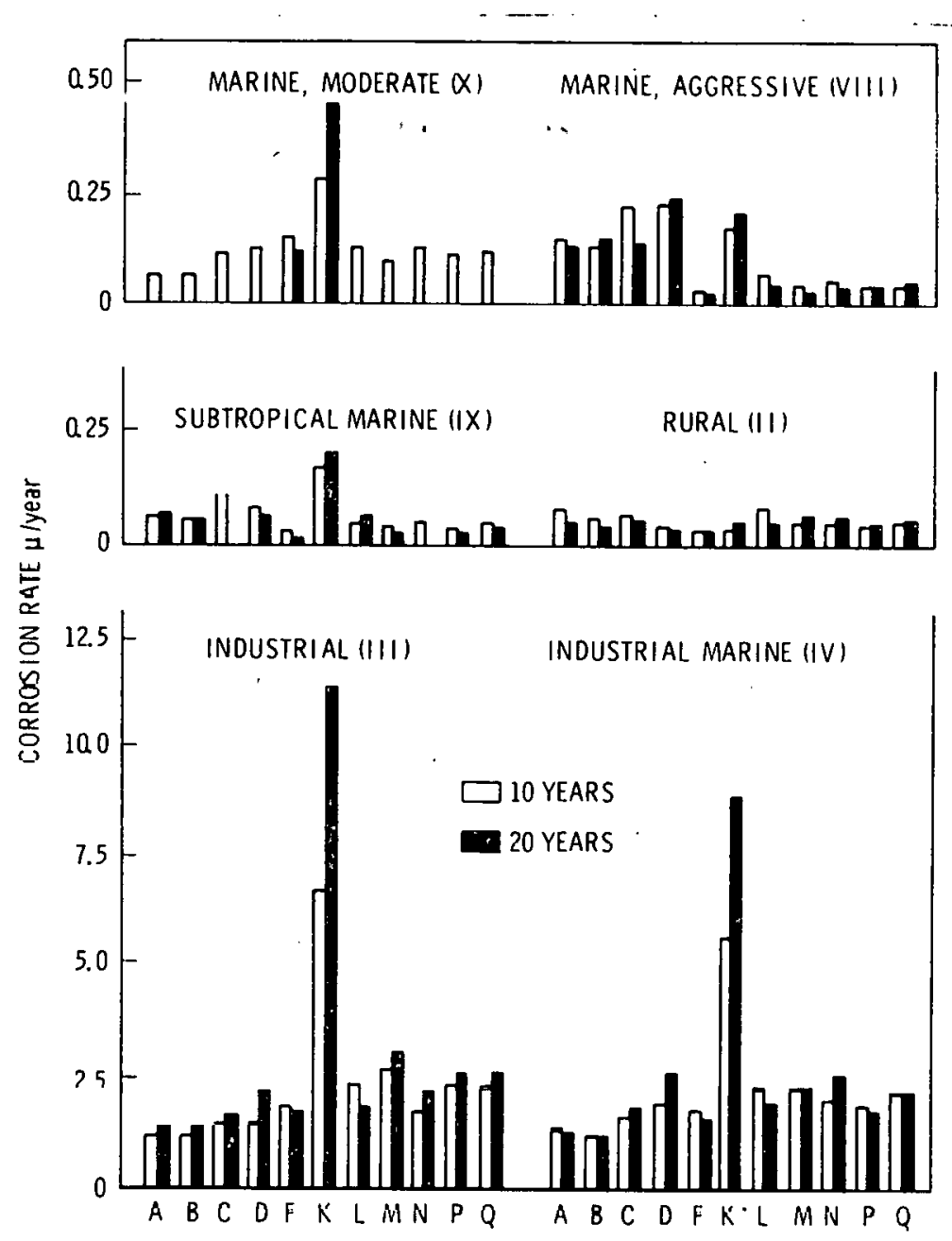

Letters on the abscissa axis, arbitrary designations of alloys corresponding to Table 29.

FIGURE 41. Corrosion of Copper Alloys in Atmospheric Tests (78) $25.4 \mu \mathrm{m}=0.001 \mathrm{in}$.

bearing copper alloys is probably attributable to the hygroscopic corrosion products developed in these alloys. Rozenfeld's data indicate that atmospheric corrosion environments affect copper alloys in the following order of decreasing corrosion severity: industrial > marine > rural. 


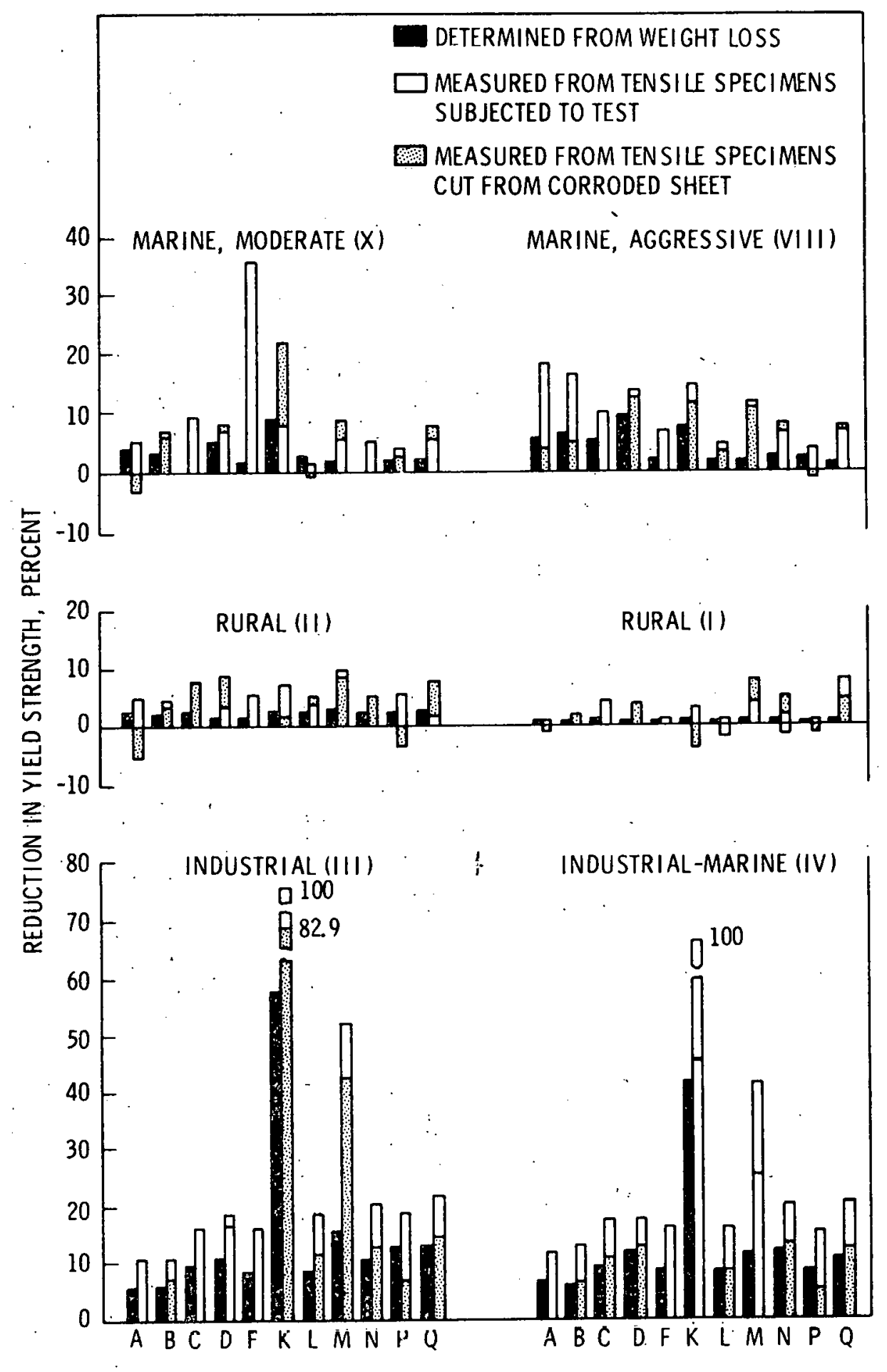

Letters on the abscissa axis, arbitrary designations of alloys corresponding to Table 29.

FIGURE 42. Corrosion of Copper Alloys from Atmospheric Tests $(78)$ (loss of tensile strength) 
Table 18 gives the CDA (Copper Development Association) designation and composition for a number of copper alloys. The most frequently used copper alloys for tubular heat exchangers are: CDA Nos. 122, 194, 443, 687, 706 and 715 . (98)

The harmful effects of the chloride ion and $\mathrm{SO}_{2}$, derived from marine and industrial sources respectively, have been discussed previously. Sulfurbearing contaminants are generally inimical to the corrosion stability of copper and copper alloys, with $\mathrm{SO}_{2}$ predominant in this respect. Corrosion due to $\mathrm{SO}_{2}$ depends on the presence of condensed water; therefore, corrosion in an $\mathrm{SO}_{2}$ atmosphere would be sensitive to both $\mathrm{SO}_{2}$ concentration in the air and relative humidity. The relevance of this fact for copper is illustrated in Figure 43, showing the corrosion effect (weight gain) as a function of exposure time for various combinations of relative humidity $(\mathrm{RH})$ and $\mathrm{SO}_{2}$ concentration. (78) Curve (1) corresponds to dry air (0\% RH) with $10 \% \mathrm{SO}_{2}$. This condition gives minimal corrosion, somewhat less than a moist $(100 \%$ $\mathrm{RH})$ atmosphere with no $\mathrm{SO}_{2}$ contamination (curve 2). The maximum corrosion is caused by the $50 \% \mathrm{RH}-10 \% \mathrm{SO}_{2}$ combination (curve 8 ). While alloying would change these corroston characteristics, all copper-base allnys have increased corrosion rates in sulfur-bearing cases. The practical consequences of this fact depend on the particular service application and the ability of the copper alloy to develop a protective film coating incorporating sulfur species.

While the chloride ion is an aggressive species for most metals, copper is among the few metals which can develop passivity in a chloride bearing electrolyte. In consequence, if the exposure conditions permit formation of a protective film, incorporating the chloride ion, then copper alloys will exhibit good stability under marine atmospheres. The relative potency of the chloride and sulfate ions in promoting anodic activity of copper is shown in Figure 44, showing the applied potential-corrosion current characteristics for chloride and sulfate solutions. (87) Curve (4) corresponds to the sulfate solution under a large volume of electrolyte. There is no tendency to polarize (develop resistance to anodic current) in this case. The 


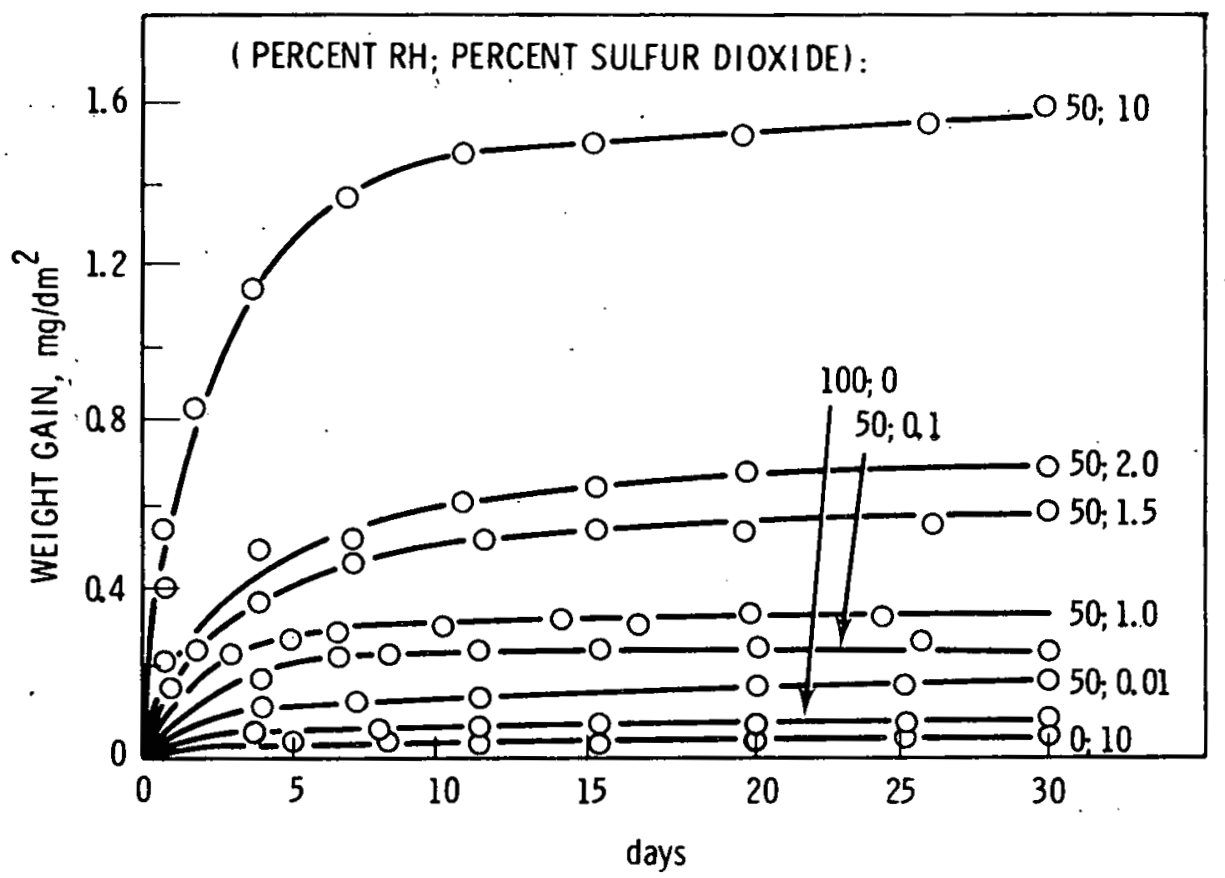

FIGURE 43. Effect of $\mathrm{SO}_{2}$ Concentration on Copper Corrosion at Various Relative Humidities $(\mathrm{RH})(78)$

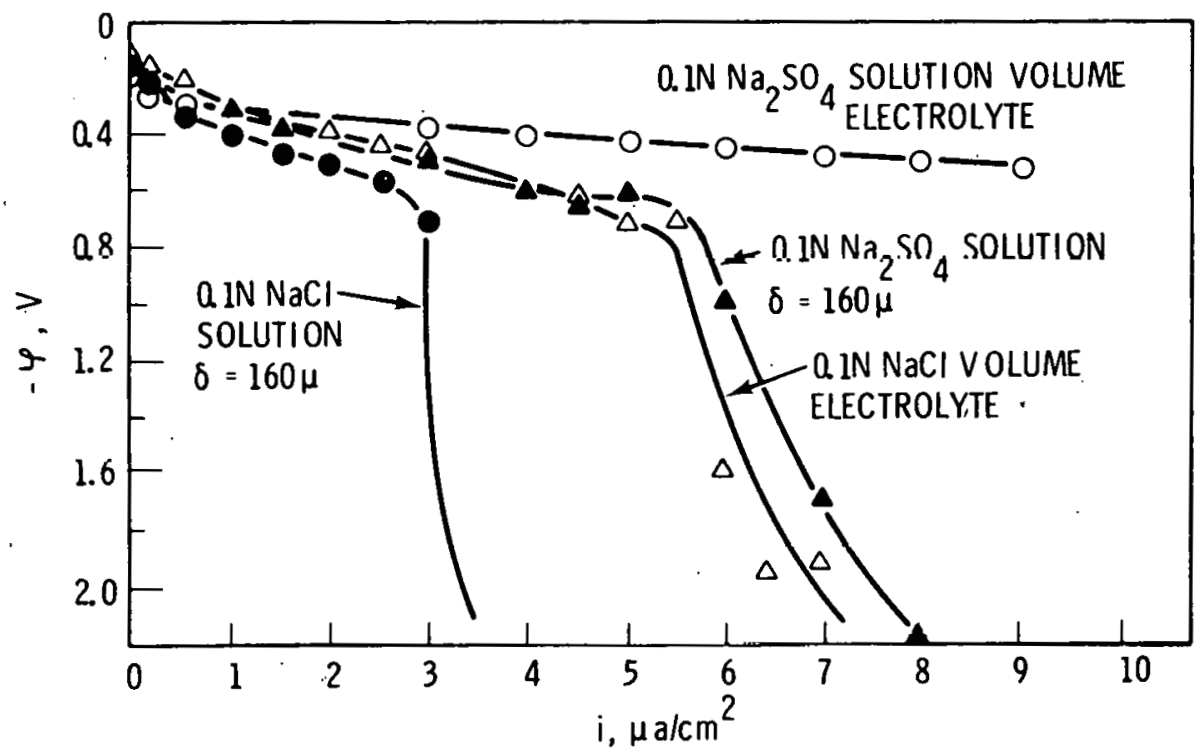

FIGURE 44. Curves of Anodic Polarization of Copper in $0.1 \mathrm{~N}^{\mathrm{Na}_{2} \mathrm{SO}_{4}}$ and $0.1 \mathrm{~N} \mathrm{NaCi}$ Solutions of Different Thickness $(87)$ 
curve for the chloride solution (curve 2) exhibits a strong polarization (sharp rise in positive potential needed to drive the cell at increasingly higher anodic currents).

The protective film developed on copper and copper alloys is called patina. In the presence of chloride ions, the patina may be largely basic copper chloride $\left(\mathrm{CuCl}_{2} \cdot 3 \mathrm{Cu}(\mathrm{OH})_{2}\right)$. In the presence of $\mathrm{SO}_{2}$ or other sulphurbearing species, the patina may consist of basic copper sulfate $\left(\mathrm{CuSO}_{4}\right.$. $\left.3 \mathrm{Cu}(\mathrm{OH})_{2}\right)$. In marine-industrial atmospheres, the patinas may incorporate both of the above basic copper compounds. According to Rozenfeld, (78) the copper sulfate patina predominates on a worldwide basis.

Guttman and Sereda $(99)$ attempted to correlate copper alloy corrosion with the following environmental factors: time-of-wetness, specimen temperature while wet, $\mathrm{SO}_{2}$ and $\mathrm{Cl}$ levels of atmosphere. Up to about 12 months, copper corrosion correlated well with the factors. For longer periods, of more practical interest, the influence of these factors was secondary to the control exerted by the corrosion product film which had developed on the alloy during the previous 212 -month exposure.

\subsubsection{Corrosion Mechanisms - Copper Alloys}

In accord with previous discussion, it is evident that many factors control the ability of a copper alloy to develop a protective patina. For example, patinas generally form more rapidly on boldly exposed surfaces facing south (northern hemisphere). Where there is persistent air contamination, patinas will form faster when exposed to the prevailing wind. As an added factor, solar radiation is believed to stimulate corrosion reactions on a cöpper surface. (83)

Ammonia is a strong complexing agent for copper and in the presence of water, ammonia solutions are strongly corrosive to copper and copper alloys. Halogens ( $\mathrm{C} 1, \mathrm{Br}, \mathrm{I}, \mathrm{F})$ and their hydrogen compounds react strongly with most copper alloys. At elevated temperatures, in dry as well as humid atmospheres, tin bronzes will corrode severely due to the formation of volatile tin-halide compounds. 
Copper alloys are generally subject to stress corrosion cracking under suitable stress, moisture, contaminant and metallurgical conditions. The brasses, with over $20 \%$ zinc, appear to be particularly susceptible to stress corrosion cracking. The cracking tendency tends to increase with increasing alloy complexity, in accord with previous comments on the SCC of aluminum alloys. Pure copper is practically immune to SCC, but can be cracked by strong $\mathrm{NH}_{3}$ solutions. The $\mathrm{Cu}-\mathrm{Ni}$ alloys are considered to be resistant to SCC. Ammonia over a wide range of concentrations in aqueous solutions is a particularly aggressive species causing SCC of copper alloys. Sulfur dioxide, under somewhat more restrictive concentration ranges, is also aggressive. Papplewe1] and Gearing present data for stress corrosion resistance of 25 copper alloys in atmospheric exposures. $(100)$ Specimens of the U-bend design did not fail after 8 years for many of the alloys. However, alloys containing more than $20 \%$ zinc were susceptible to failure. Industrial sites were more aggressive than marine sites.

Copper alloys exhibit pitting corrosion, crevice attack and intergranular corrosion under some conditions. Many of the factors involved in these aspects of corrosion have been discussed previously. Of the specific chemical species active in these processes, the sulfur-bearing gases, ammonia and ammonia derivatives, are most prominent. The chioride ion promotes copper corrosion, though as noted above, copper and copper base alloys have a relatively good resistance to chloride intrusion. 


\subsubsection{Galvanized Steel}

As indicated earlier, galvanized steel is one of the two materials now used for finned tube construction in operating power plant dry cooling towers. The galvanizing process used for heat exchanger components involves application of a zinc coating to the steel finned tube assembly by immersion in a zinc metal bath. The simultaneous coating of tubes and fins precludes crevices at the fin/tube joint. The galvanizing process temperature is $2450^{\circ} \mathrm{C}$ ( $840^{\circ} \mathrm{\circ} F$ ). Process details are discussed by Nishimura. (101) Bonding of the zinc to the steel substrate occurs through intermetallic layers which form during the galvanizing process.

For a rimmed (unkilled) steel,* immersion in a molten zinc bath coats the steel with a minimum of 2 oz of $z i n c / \mathrm{ft}^{2},(102)$ which corresponds to a. coating thickness of $3.4 \mathrm{mils}(0.086 \mathrm{~mm})$ on each surface of the material being galvanized (per ASTM A-123). For semi- and fully-killed steels, $t$ the coating weight can be at least twice this amount. Reference 102 indicates typical coating thicknesses of $27 \mathrm{mils}$ for heat exchangers. The total fin thickness from GEA finned tube samples is 15 to 17 mils. The galvanized film thickness was found to be 2 to 3 mils.

Depending on the required lifetime and the atmospheric contaminants, heaviei cualiny weighls lllay be required. (103) In addition to the ettects of steel chemistry on coating weights referred to above, the galvanizer can exercise a limited degree of control in the process to produce a nominally heavier coating than normal even for an unkilled steel chemistry.

The utility of galvanized steel is indicated by the fact that more zinc is exposed to the atmosphere, on an area basis, than any other metal.(83)

* A rimmed steel is a low-carbon steel containing sufficient iron oxide to give a continuous evolution of carbon monoxide while the ingot is solidifying, resulting in a case or rim of metal virtually free of voids. Sheet and strip products made from the ingot have very good surface quality.

t A killed steel is steel that is deoxidized with a strong deoxidizing agent such as silicon or aluminum in order to reduce the oxygen content to such a level that no reaction occurs between carbon and oxygen during solidification. 


\subsubsection{Atmospheric Corrosion Data - Galvanized Steel}

Figure 45 shows galvanized coating service life as a function of zinc coating thickness and the type of atmospheric environment. (102) In clean air, zinc is attacked only slightly, even with high moisture contents. When the air contains impurities, effects of moisture are correspondingly more severe. The relationship between service life and plate thickness is essentialiy linear.

Table 30 summarizes life expectancy data for galvanized steel sheets exposed to industrial, rural and marine environments. The table shows time to rust and to perforation for $2.5 \mathrm{oz} / \mathrm{ft}^{2}$ coatings and estimated time to first rust for $4.1 .0 z / \mathrm{ft}^{2}$ coatings. Field repair procedures are

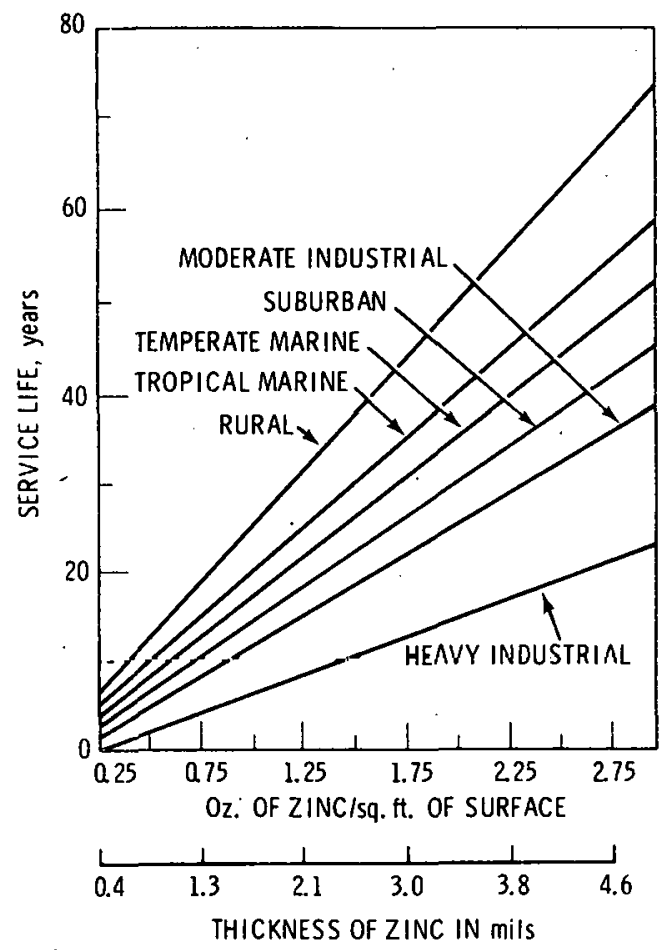

SINCE THE LENGTH OF TIME A ZINC COATING WILL LAST IS DIRECTLY PROPORTIONAL. TO THF THICKNFSS RF THF ZINC COAT, EACH OF THE STRAIGHT LINE GRAPHS SHOWN ABOVE MAY BE EXTENDED TO SHOW THE LIFE EXPECTATIONS WITH HEAVIER COATS OF ZINC.

FIGURE $45 . \quad$ Service Life of Zinc Coatings Versus
Zinc Thickness $(102)$. 
TABLE 30: Life Expectancy of Galvanized Steel Sheets (102)

$\therefore \quad$ Covering Periods 1926 to $1965-21 / 2 \mathrm{oz} / \mathrm{ft}^{2}$ of Coating

(ASTM A-5 SUBCOMMITTEE XIV)

\begin{tabular}{|c|c|c|c|c|c|}
\hline Site & $\begin{array}{c}\text { Years } \\
\text { lst Rust } \\
\end{array}$ & $\begin{array}{c}\text { Years } \\
100 \% \text { Ruct }\end{array}$ & $\begin{array}{l}\text { First } \\
\text { Perfor- } \\
\text { ation } \\
\end{array}$ & $\begin{array}{l}\text { Uncoated } \\
\text { Steel Coat } \\
\text { Perferation }\end{array}$ & $\begin{array}{l}\text { First Rust* } \\
\text { Calculated } \\
4.1 \text { oz/ft }{ }^{2} \\
(7 \mathrm{mil}) \\
\end{array}$ \\
\hline $\begin{array}{l}\text { Sovore (I) } \\
\text { Industrial }\end{array}$ & 5.9 & 14.4 & 19.5 & 2.0 & 20.0 \\
\hline $\begin{array}{l}\text { Severe }(2) \\
\text { Industrial }\end{array}$ & 4.6 & 11.2 & 17.5 & 4.3 & 15.0 \\
\hline Rural (3) & 28.7 & $\begin{array}{c}\text { none after } \\
39 \text { years }\end{array}$ & $\begin{array}{c}\text { none after } \\
39 \text { years }\end{array}$ & 24.0 & 96 \\
\hline $\begin{array}{l}\text { Atlantic (4) } \\
\text { Coast Marine }\end{array}$ & 13.1 & $23(\min )$ & $\begin{array}{l}\text { none after } \\
25 \text { years }\end{array}$ & 4.9 & 42 \\
\hline $\begin{array}{l}\text { Rural (5) } \\
\text { Marine }\end{array}$ & 19.8 & -- & $21.5 \mathrm{~min}$. & 3.6 & 64 \\
\hline
\end{tabular}

(i) Brunot Island - Pittsburgh, Pa.

(2) Altoone, $P a$.

(3) State College, Pà.

(4) Sandy Hook, N. J.

(5) Key West., Fla.

*Calculated years to first rust at $4.10 \mathrm{oz} \mathrm{ft}^{2}$. A free zinc layer may be absent in semi- and fully-killed galvanized steels, and the coating may exhibit traces of rust at a fairly early date. This staining should not be misinterpreted as failure of the coating. 
available for galvanized coatings. However, the fin geometries on drycooled assemblies would appear to present difficulty for any large scale repair operation.

Reference 78 presents corrosion rates and loss of tensile strength data for various galvanized coating thicknesses after 10- and 20-year exposures. Industrial and industrial/marine environments were the most aggressive.

\subsubsection{Corrosion Mechanisms - Galvanized Steel}

The protective character of zinc in atmospheric exposures has two principal aspects:

- The general corrosion resistance depends on formation of a protective oxide. Zinc oxide gives optimum protection; basic zinc carbonate also is protective.

- At holidays or breaks in the film the zinc provides sacrificial protection to the steel substrate, being anodic to steel.

Figure 46 shows the influence of $\mathrm{SO}_{2}$ and moisture on the corrosion of zinc, demonstrating increasing corrosion rates with increasing concentration of both species. ${ }^{(83)}$ Periodic wetting is generally more harmful than continuous immersion.

Like aluminum, zinc is amphoteric; both acid and basic solutions will dissolve the zinc corrosion products. Zinc corrosion passes through a minimum, with increasing $\mathrm{pH}$, as does aluminum. ${ }^{(32)}$ Zinc exhibits pitting corrosion under certain conditions. This includes situations where there is a differential oxygen supply to the zinc surface, and physical-chemical dissimilarities, as discussed in connection with aluminum. However, zinc generally shows less pitting tendency than copper or aluminum, because it develops general overall corrosion. Uniform penetration data are usually a good basis for judging the severity of corrosion attack.

Figure 47 provides an interesting correlation between the corrosion effect (weight loss) and the amount of $\mathrm{SO}_{2}$ absorbed by zinc (a measure of $\mathrm{SO}_{2}$ content in the atmosphere), as a function of the calendar month. (83) The 


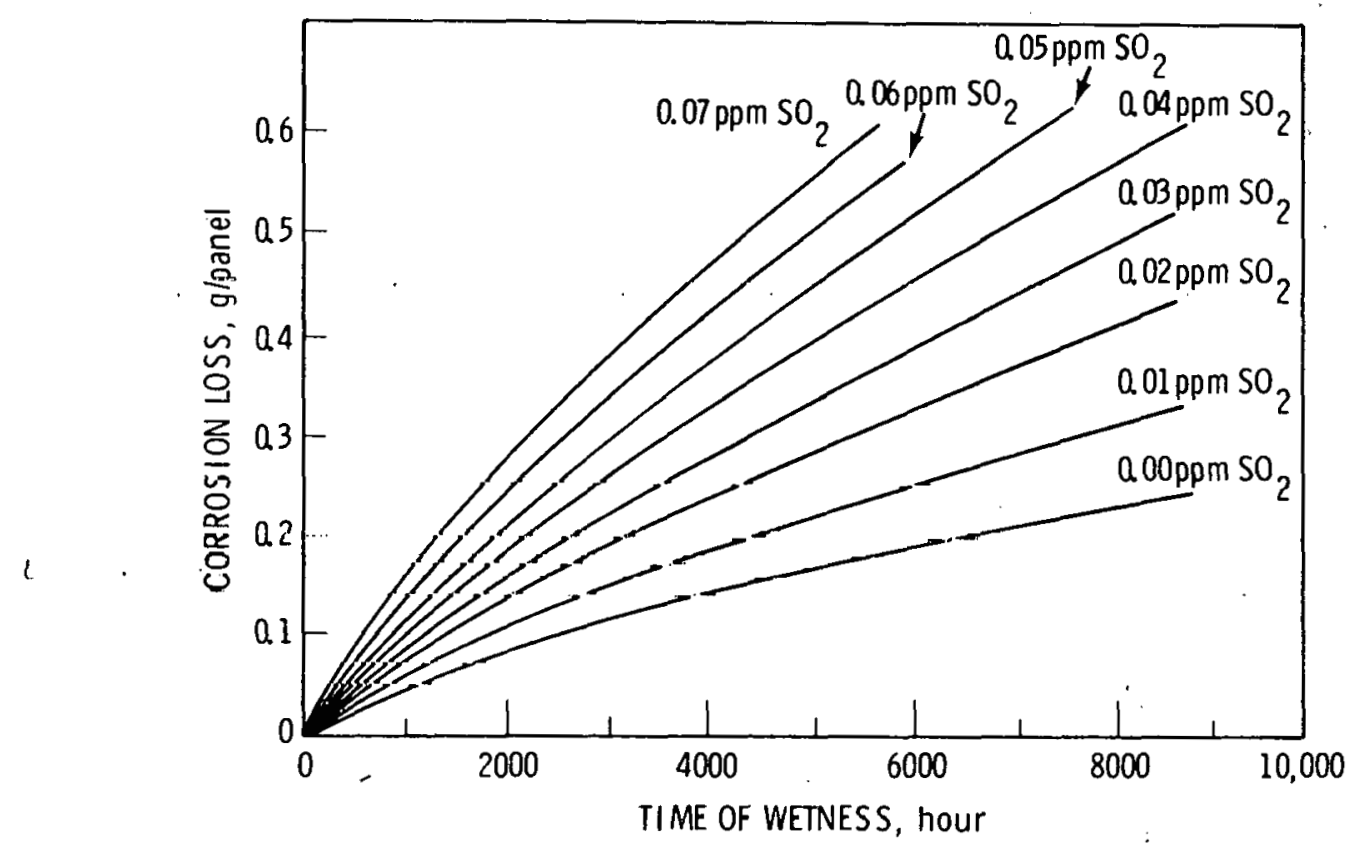

FIGURE 46. Graphical Presentation of Empirical Equation . $y=0.0005461$ (A) $0.3152 \times(3+0.02359)$

Showing the Effects of Time of Panel Wetness and Atmospheric Sulfur Dioxide on the Corrosion of Zinc (83)

corrosion-date characteristic follows the $\mathrm{SO}_{2}$-date curve quite closely. Ihe fact that the highest corroston occurs during the coldest period again illustrates the complex, and often surprising, temperature effect in atmospheric corrosion. Here, the season and the low temperature apparently favored a greater incidence of condensed water on the specimens. This, together with the high $\mathrm{SO}_{2}$ concentration, maximfizes the corrosion despite the relatively low temperatures.

Zinc occupies a nearly extreme position on the anodic (corrosion active) end of the galvanic series yiven previously. While this position is reflected under some extreme corrosion situations, generally zinc develops a stable corrosion film during atmospheric exposures. These characteristics provide the basis for the strong competitive position of. zinc among possible metallic plating materials. 


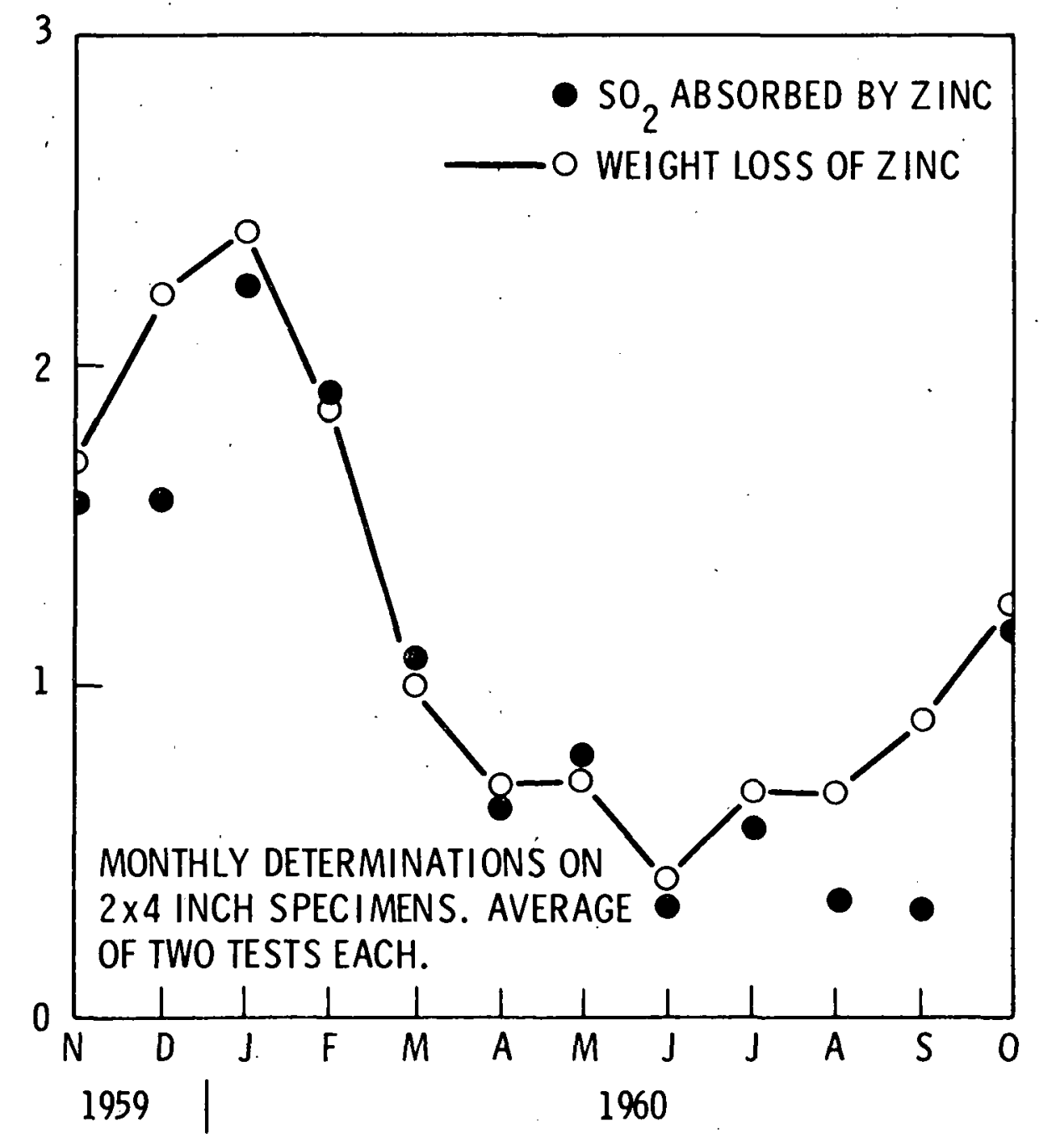

FIGURE 47. Equivalence Between Sulfur Dioxide Taken up by Zinc and Atmospheric Corrosion of Zinc at Stuttgart(83)

\section{DRY COOLING TOWER CORROSION REFERENCES}

Several publications have addressed corrosion and material performance in dry cooling towers. Most have been previously referenced, but are briefly described here to indicate the scope of relevant U.S. literature available and the general topics which each discusses.

1. Dry Cooling Towers Study, prepared for West Associates, by Bechtel Corporation, April, 1971. 
- Advantages and drawbacks of aluminum, steel, galvanized and copper materials. Copper cannot compete with steel and aluminum, due to cost.

- Carbon steel corrosion after system is drained - need for nitrogen blanketing of internal system during outages.

- Water chemistry control.

2. Research on Dry-Type Cooling Towers for Thermal Electric Generation, TID-26515, R. W. Beck and Associates, December, 1973.

- Materials selection.

- Fin design.

- Marley corrosion tests.

- Hudson views on corrosion and coatings.

- Corrosion and water chemistry in operating plants: Ibbenburen, Rugeley, Volkswagen and Wyodak.

3. E. S. Miliaras, Power Plants with Air-Cooled Condensing Systems, The MIT Press, Cambridge, MA, 1974.

- Corrosion and water chemistry in several operating direct and indirect dry cooled plants.

4. Study of Dry-Type Cooling Towers and Their Application to Large Nuclear Power Plants, Catalytic, Inc. COD-2391-1, 1974.

- Comparison of advantages, disadvantages and coats of numerous coating alternatives.

- Service life for galvanized coatings.

- Rugeley corrosion problem.

5. David R. Clements and R. A. Bonewitz, Performance of Finned Aluminum Heat Exchanyers in Power Plant Dry Cooling Tower Service, ALCOA, 1972 . 
- General atmospheric corrosion characteristics of aluminum.

- Procedures for measuring atmospheric corrosion rates.

- Atmospheric corrosion data for aluminum in various environments to 30 years.

- Comments on Marley corrosion tests and corrosion at Rugeley, Ibbenbüren, Gyönogös and in the process industry.

- Projection of corrosion of aluminum in dry cooled plants.

6. W. H. Caruthers, Jr., Corrosion Performance of Aluminum Finned Dry Cooling Tower Coils at Neil Simpson Station, Wyodak, WY, Reynolds Metals Co., January, 1973.

- Description of aluminum alloy performance after 11 years at Wyodak.

7. R. E. Cates and J. A. Nelson, Dry Cooling Towers for Large Power Installations, Marley Co., March, 1973.

- Presentation of corrosion data from accelerated atmospheric corrosion tests of aluminum alloy fins.

- Presentation of aqueous corrosion data from condensate flowing through aluminum and copper alloy tubes.

8. J. E. Hall and G. C. Blaze, Performance of Aluminum Alloys at Black Hills Power and Light, Neil Simpson Station, Wyodak, WY, Alcoa Rept. 5-XE-533, June, 1973.

- Results of inspections of aluminum alloys used in various applications in a dry-cooled power station, after 11 years of exposure. 


\section{DRY COOLING TOWER CORROSION RESEARCH}

\section{CORROSION RESEARCH NEEDS}

The foregoing survey provided insights to the areas where additional research is needed to supplement or clarify existing information. These are suggested areas of research for the long-range application needs of dry cooling tower systems directed to power plant applications. Much of this is already under development and application by the industry and is continued to be researched and updated as new information surfaces. Industrial firms have been researching aluminum and galvanized steel corroston for over 40 ycars and are continuing to do so. The air cooler manufacturers are aware of field problems and are continually upgrading their designs and materials. New wet/dry cooling systems are being proposed and tested in many areas of the world.

This suggested list of research needs is specifically directed toward dry cooling tower systems for power plant application. This list should not be construed to mean that large dry cooling towers could not be purchased today and used with reasonable confidence by the electric utility industry. The designs, the metallurgy and the ambient atmosphere must a 11 be compatible for trouble-free, long-life, application. Current knowledge and technology makes this possible today; however, further quantitative data in the areas listed below would be very useful in minimizing the penalties of corrosion.

\section{Research Related to Air-Side Corrosion}

1 - Quantitative corrosion data under dry cooling tower operating conditions are needed. The data should be obtained, when possible, with parallel data under ambient atmospheric conditions at the same sites.

2 - Effects of temperature on corrosion by major atmospheric contaminants and contaminant combinations need to be assessed for dry cooling tower operating conditions.

3 - Effects of fin design on heat transfer degradation by corrosion need to be studied as a function of contaminant species and concentrations. 
4 - Corrosion monitoring methods need to be developed, beginning during site evaluation, extending through plant construction and operation. The monitoring methods should include provisions for corrosion observations in the plant operating temperature regime.

5 - Optimum procedures need to be identified for pre-installation, prestartup, and layup storage of corrosion-prone equipment.

6 - Optimum cleaning methods for fin surfaces need to be identified as a function of fin design and contaminant species.

7 - Studies are needed to evaluate corrosion and deposition in deluge systems as a function of fin material and water quality.

\section{Research Related to Steam/Water Corrosion}

1 - A systemmatic assessment is needed of the conditions which promote troublesome corrosion product transport and deposition in systems utilizing dry cooling towers. Circuits where there is a mechanism for cyclic removal of dissolved corrosion product are particularly vulnerable, such as condensate flowing to the boiler, returning as steam to the tower. Some operating dry-cooled plants have experienced mild corrosion product transport problems. Problems of this type would be magnified due to much larger tower surface areas in large ( 21000 Mile) plants.

2 - Assessment of optimum water treatment methods is needed for makeup water of various qualities found in water-scarce areas, from the standpoint of corrosion control and cost-effective water treatment.

3 - Indepth assessment is required of identifiable localized corrosion failure mechanisms which could result in component failure in dry cooling tower operating regimes, supplementing the preliminary assessment provided in this report.

4 - Reconfirmation of aluminum on an engineering scale as a surface condenser candidate material is needed. Aluminum surface condensers have been built and some are still operating. However, corrosion problems have resulted in removal of aluminum from the current list 
of surface condenser candidates. The most difficult corrosion problems have arisen from once-through cooling water. In dry cooling tower systems, water chemistries will be more benign and aluminum appears to be an attractive candidate for surface condensers in drycooled systems.

5 - The water chemistry control options for various dry-cooled concepts need further evaluation including:
a) the "neutral" method
h) the alkạline method
c) inhibitor methods

6 - The cost effectiveness of additional dry cooling tower candidate materials, such as copper-base alloys and titanium should be updated periodically.

7 - Some basic corrosion data appear to be lacking in dry cooling tower operating regimes, such as corrosion rates as a function of steam and water flow rates for the principal dry cooling tower circuit materials under prototypic water chemistry conditions. 


\section{FUTURE DEVELOPMENT OF A DRY COOLING TOWER CORROSION DATA BASE}

The successful design and operation of a dry-cooled power station depends on two essential factors: a) availability of an adequate data base for proper selection of materials and operating procedures; b) translating the principles of successful operation into practice. Improper materials selection and process specification can result in problems due to corrosion. Some problems occur due to factors which could not have been foreseen at the time the plant was designed. However, all to frequently, corrosion problems occur from improper or incomplete application of known procedures.

Looking ahead to the prospect of large dry-cooled power plants, there are major incentives to prevent untimely replacement of the tower components, including the sizable capital expenditure, the expense of replacement power if plant capacity is reduced, and the growing need to minimize wastage of resources.

Much corrosion information relevant to dry cooling tower technology has been published and a major cross section of the information is referenced in this report. The recommendations for additional corrosion studies, outlined above, include a) assimilation of existing information; b) generation of essential data which are not now available in laboratory and pilot studies; c) systemmatic studies of materials performance in operating drycooled plants.

As the various corrosion problems are addressed, forums for presentation and discussion of experimental results will be necessary. Corrosion symposia specific to dry cooling tower technology will need to be organized, under the auspices of major societies. The National Association of Corrosion Engineers (NACE) has standing committees in the areas of aqueous corrosion ( $T-11)$ and behavior of coatings in atmospheric exposures $(T-6 H)$, and Atmospheric Corrosion (T-3R). Under the American Society for Testing and Materials (ASTM), Committee G-1 has made major contributions in the area of atmospheric corrosion. Involvement of an organization such as the Heat Exchange Institute, at least in an advisory capacity, also appears desirable. 
Foreign participation in the corrosion forums will be important, both from the standpoint of basic studies and operating experience from drycooled plants.

No formal plans have been developed for dry cooling tower corrosion symposia, but there are tentative plans for a symposium at the NACE Conference, CORROSION/78, to be held in March 1978, at Atlanta, Georgia.

Consideration needs to be given to the most effective methods to provide a substantial basis to avoid major problems due to corrosion. Development of a dry cooling tower corrosion handbook appears to offer the type of focused data presentation which is needed. The scope of the handbook would include air-side corrosion data under ambient and dry cooling tower operating regimes, and corrosion data for candidate materials in water and steam.

Another major method to bring the available corrosion technology to bear on the specific needs of dry cooling towers is through the development of corrosion standards and operating guides for industrial plants. Standards development for both air-side and aqueous corrosion control should be considered.

Existing heat exchanger and condenser standards do not make provisions for protection against corrosion of fin, tube and condenser materials. For example, the publication: Standards for Direct Contact Barometric and Low Level Condensers, * indicates a value for corrosion allowance, but does not indicate procedures for corrosion control.

The existing standards can be broadly categorized as: a) testing standards; b) standards for plant construction and operation.

The principal sources of corrosion standards are:

- American Society for Testing and Materials (ASTM)

- National Association of Corrosion Engineers (NACE)

* Copyright 1970 by the Heat Exchange Institute, 122 East 42nd Street, New York, NY 10017 
- Military and Federal Standards and Specifications (MIL, FED)

- American Society of Mechanical Engineers Pressure Vessel-Code Material Specifications (ASME)

- Foreign Standards

- Specific Industry Standards, for example, Nuclear - U.S. Atomic Energy Commission (Now Energy Research \& Development Administration), Division of Reactor Development and Technology (RDT) - Heat Exchange Institute Standards; American Petroleum Institute (API) Standards.

A 1973 ASTM publication summarizes industrial corrosion standards in ten segments of industry. (104) While the needs of the dry cooling industry are not addressed directly, the publication provides insights to the general approaches and levels of sophistication regarding the application of corrosion standards in various industries.

Numerous testing standards for pre-operational evaluation of materials have been developed and documented. These involve methods of atmospheric corrosion testing, use of salt spray tests, various environmental chambers, and electrochemical corrosion tests.

The application of corrosion standards and operating guides to plant construction and operation is much less advanced. Examples of areas where documented guides and standards appear to have potential value are:

- packaging, shipping, storage, installation and layup procedures for various dry cooling tower components ;

- optimun cleaning procedures for dry-cooled modules as a function of material and finned tube design;

- corrosion monitoring procedures for air-side and aqueous corrosion control;

- water treatment procedures as a function of water quality and system design.

Dry cooling tower technology development over the next decade should factor in the timely generation of a corrosion data base which will minimize the economic penalties of corrosion in its own industry and provide standards and guides of potential valuc to other segements of industry. 


\section{REFERENCES}

1. D. E. Peterson, G. F. Bailey, S. L. Engstrom and P. M. Schrotke, Thermal Effects of Projected Power Growth: The National Outlook, HEDL-TME-73-45 (July 1973).

2. Dry Cooling Tower Program: Results of Industrial Contacts Through August 1974, BNWL-1878, November 1974.

3. J. P. Rossie and E. A. Cecil, "Research on Dry-Type Cooling Towers for Thermal Electric feneration," R. W. Reck and Associates, renort. prepared for the Federal Water Quality Administration, November 1970.

4. Dry Cooling Towers Study, prepared for West Associates by Bechtel Corporation, Aprii 1971.

5. E. S. Miliaras, Power Plants with Air-Cooled Condensing Systems, The MIT Press. Cambridge, MA, 1974.

6. D. Hirschfelder, "Dry Cooling Tower for the 300 MW TH R Nuclear Power Plant Schmehausen," AEC-tr-7428, 1973.

7. J. Buxmann and H. Heeren, "Surface Condensers for Dry Cooling?" Power, 80, Apri1 1975.

8. M. E. Lapides and E. Zebroski, "Use of Nuclear Plant Operating Experience to Guide Production Improvement Progress," EPRI SR-26-R, November 1975.

9. J. P. Rossie. R. D. Mitchell and R. O. Young, "Economics of the Use of Surface Condensers with Dry-Type Cooling Systems for Fossi1Fueled and Nuclear Generating Plants," Report prepared for the USAEC by R. W. Beck Associates, December 1973.

10. W. V. Loscutoff, Prel iminary Evaluation of Wet/Dry Cooling Concepts for Power Plants, BNWL-T969, Uecember 1975.

11. E. C. Smith and A. Y. Gunter, "Cooling Systems Combining. Air and Water as the Coolant," ASME 72-HT-29, 1972.

12. W. Kals, "Wet-Surfare Aircoolers," Chem. Engrg., 78(14),90 July 1971.

13. Report of the USA Dry and Wet/Dry Cooling Tower Delegation Visit to the USSR, ERDA-105, (May 26-June 7, 1975).

14. R. E. Catcs and J. A. Nelsnn, "Dry Cooling Towers for Large Power Installations," The Marley Company. 1973.

15. A. J. Haygood and J. D. Minford, "Aluminum Cooling Towers and Theory Treatment," Corrosion, 15, 20t, January 1959.

16. J. G. DeSteese and K. Simhan, "European Dry Cooling Tower Operating Experience," BNWL-1995, 1976. 
17. A. Berzins, J. V. Evans and R. T. Lowson, "Corrosion of Aluminum in Pure Water and Dilute Solutions," AAEC/E-270, 1970.

18. J. Draley and $W$. Ruther, "Aqueous Corrosion of Aluminum - Part 1 , Behavior of 1100 Alloy," Corrosion, 12, 441t, 1956.

19. R. L. Horst, Jr., and R. T. Marchese, "Aluminum Surface Condenser Tubes for Steam Power Plants," ASME 62-WA-300, 1962.

20. W. W. Binger, E. H. Hollingsworth and D. 0. Sprowls, "Resistance to Corrosion and Stress Corrosion," in Aluminum, vol. T, American Society for Metals, Metals Park, OH, 1967.

21. R. H. Wagner and B. H. Wyma, "Aluminum Equipment for Handling HighPurity Water and Steam Condensate," ALCOA, Application Engineering Division, Report TR-519, February 1963, (not released for publication).

22. W. W. Binger and C. M. Marstiller, "Aluminum Alloys for Handling HighPurity Water," Corrosion, 13, 591, 1957.

23. A. Bakay and I. Szabo, "Water Chemical Experiences with the Neutral Water Cycle in Power Stations with Air-Cooled Condensation," Appendix VI of Reference 13.

24. E. G. Brush and W. L. Pearl, "Corrosion and Corrosion Product Release in Neutral Feedwater," Corrosion, 28, 129, 1972.

25. S. G. Sawochka and W. L. Pearl, "Cutting Corrosion Products in Nuclear Plants," Power, 83, October 1971.

26. R. K. Freier, "Deckschichtbildung Auf Stahl Durch Sauerstaff in Neutralem, Salzfreiem Wasser," Sonderdruck VGB-Speisewassertagung, $11,1969$.

27. P. J. Christopher and V. T. Forster, "Rugeley Dry Cooling Tower System," Proc. Instr. Mech. Engrs., 184, (1)197, 1969.

28. "Seminar on the Performance of Condensers on Nuclear and Fossil Power Plants," Cosponsored by EPRI, ASME and OSU, Columbus, OH, June 1975.

29. D. R. Clements, "Aluminum Condenser Tubing for Electric Generating Facilities," ALCOA Memorandum (June 1969).

30. S. Mori and J. E. Draley, "Oxide Dissolution and Its Effect on the Corrosion of 1100 Aluminum in Water at $70^{\circ} \mathrm{C}, " J_{2}$. Electrochem. Soc., 114, $352(1967)$.

31. J. E. Draley, S. Mori and R. E. Loess, "The Corrosion of 1100 Aluminum in water from $50^{\circ} \mathrm{C}$ to $95^{\circ} \mathrm{C}$, J. Electrochem. Soc., 114, 353 (1967). 
32. H. H. Uhlig, Corrosion and Corrosion Control, Second Edition, John Wiley \& Sons, Inc., New York (1971).

33. N. Cabrera and N. F. Mott, Repts. Prog. Phys., 12, 163 (1949).

34. J. E. Draley and W. E. Ruther, "Aqueous Corrosion of $2 S$ Aluminum at Elevated Temperatures," ANL-5001, (February 1953).

35. R. L. Dillon, "Observations of the Mechanisms and Kinetics of Aqueous Aluminum Corrosion II," HW-71756 (November 1961).

36. R. L. Dillon, "Observations on the Mechanisms arld Kinetics of Aqueous Aluminum Corrosion," Corrosion, 15, $13 t$ (1959).

37. F. W. Fink, Battelle Columbus Laboratories, personal communication, May 13, 1975.

38. T. Pearson and H. Phillips, "Corrosion of Pure Aluminum," Met. Rev., 2, 305 (1957).

39. H. P. Godard, W. B. Jepson, M. R. Bothwell and R. L. Kane, The Corrosion of Light Metals, Wiley, New York (1967).

40. W. D. France, Jr., "Crevice Corrosion of Metals," in Localized Corrosion--Cause of Metal Failure, ASTM Special Technical Pub7ication 516,164 (1972).

41. K. Videm, "Pitting Corrosion of Aluminum in Contact with Stainless Steel," Institutt for Atomenergi, Kjeller Research Establishment (May 1962).

42. J. Draley and W. Ruther, "Some Unusual Effects of Hydrogen in Corrosion Reactions," J. Electrochem. Soc., 104, 329 (1957).

43. J. E. Draley, S. Mori and R. E, Loess, "The Corrosion of 1100 Aluminum in Oxygen--Saturated Water at $70^{\circ} \mathrm{C}, "$ J. Electrochem. Soc., 110, 622 (1963).

44. K. Lehner, Wisconsin Electric Power Company, personal communication, March 6, 1975.

45. J. L. English and J. C. Griess, "Dynamic Corrosion Studies for the High-Flux Isotope Reactor," ORNL-TM-1030, (1966).

46. R. F. Ford, Jr. and B. M. Gallaway, "Galvanic Corrosion with Mild Steel in a Dilute Sodium Dichromate Electrolyte," Texas A\&M Univ. Sea Grant Publ. No. 206 (1970).

47. R. Baboian, "Investigations of Galvanically Induced Localized Corrosion," in Localized Corrosion--Cause of Metal Failure, op. cit. 145. 
48. W. Stumm and J. J. Morgan, Aquatic Chemistry: An Introduction Emphasizing Chemical Equilibria in Natural Waters, Wiley, Interscience, New York (1970).

49. L. Caruso, "Choosing Cu-Alloy Tubes for Heat Exchangers," Power, $\underline{115}(8)$, 1 (1971).

50. S. F. Hager, "Application of Reduced Wall Copper--Nickel Condenser Tube," presented at the CDA-ASM Conf. on Copper, Cleveland, Ohio (October 1972).

51. S. D. Reynolds and F.W. Pement, "Corrosion Failures in Power Plant Auxiliary Heat Exchangers," Mater. Performance, 13, 21 (1974).

52. F. W. Fink and W. K. Boyd, "Corrosion Problems in Power Plant Steam Condensers," Topical Report to the Copper Development Association (May 1971).

53. D. H. Thompson, "How to Prevent Stress--Corrosion Cracking of Copper Alloys," Chem. Engr., 130, (1961).

54. D. H. Thompson, "Stress Corrosion Cracking of Copper Metals," Stress Corrosion Cracking of Metals--A State of the Art, ASTM Special Technical Publication 518, 39 (1971).

55. D. H. Thompson, "Probability as Related to Stress Corrosion Cracking of Copper Alloys," Corrosion, 15, 433t (August 1959).

56. P. Brunn and M. Schmidt, "Effect of Arsenic on Resistance of Aluminum Brass Condenser Tubes to Stress Corrosion Cracking," Proceedings 2nd International Congress on Metall ic Corrosion, NACE, P. 37 (1963).

57. S. Sato and T. Nosetani, "Effect of Additional Elements on the Stress Corrosion Susceptibility of Aluminum Brass, "Journal of the Japan Petroleum Institute, 11 (11), 857 (1968).

58. E. Kanczor, "Corrosion Fatigue Fracture," Prak. Metallogr., 2, $67(1965)$.

59. P. D. Miller and W. K. Boyd, "A Survey of Corrosion Inhibitors and Related Additives to Improve the Corrosion Resistance and Heat Transfer of Copper and Its Alloys," Report sponsored by International Copper Research Association, New York (June 1969).

60. J. R. Myers and M. F. Obrecht, "Performance and Selection of Materials for Potable Hot Water Service," Mater. Prot. and Perf. , 12, 17 (1973).

61. E. S. Johnson and H. Kehmna, "Some Relations Between Deposition and Corrosion Contamination in Low Make-up Systems for Steam Power Plants," Corrosion, 14, 429t (1958). 
62. E. G. Brush and W. L. Pearl, "Corrosion Behavior of Nonferrous Alloy Feedwater Heater Materials in Neutral Water with Low 0xygen Contents," Corrosion, 25, 99 (1969).

63. B. A. Johnson, "The Dissolution of Metal Corrosion Products in Deionized Water at $38^{\circ} \mathrm{C}, "$ Nucl. Appl. and Tech., 858 (1970).

64. G. Resch, "Neue Richwerte fi ir Kesselspeise und Kesselwasser--Ein Beitrag zur Neufassurg 1972," VGB Kraftwerkstechnik, Mitteilungen der VGB, 52 (5), 385 (October 1972).

65. G. Resch, "Eirfluss der Sauer'stoffkonzentration auf die Beständigkeit von Stahl in Wässerigen Lösurgen," VGB Kraftwerkstechnik, Mitteilungen der VGB, $49(6), 453$ (December 1969).

66. T. P. Hoar and J. G. Hines, "The Stress-Corrosion Cracking of Austenitic Stainless Steels, Part 1," J. Iron \& Steel Inst., 182, 124 (February 1956).

67. S. Barnartt and D. Van Rooyen, "Anodic Behavior of Austenitic Stainless Steels and Susceptibility to Stress Corrosion Cracking," $\underline{\mathrm{J}}$. Electrochem. Soc., 108, 222 (March 1961).

68. K. C. Thomas, H. M. Ferrari and R. J. Allio, "Stress Corrosion of Type 304 Stainless Steel in Chloride Environments," Corrosion, 20, 89t (March 1964).

6.9. K. Sugimoto, T. Maekawa and M. Kagawa, "Effects of Chloride Ion and Dissolved Oxygen on Stress Corrosion Cracking of Austenitic Stainless Steel in High Temperature Water, " Corr. Engr., 14, (April 1965).

70. M. Henthrone, "Intergranular Corrosion in Iron and Nickel Base Alloys," in Localized Corrosion--Cause of Metal Failure, op. cit., p. 66 .

71. W. E. Berry, "Corrosion Standards and Control in the Nuclear Power Industry," Industrial Corrosion Standards and Control, ASTM Spec. Tech. Pub1. 534, $144(1974)$.

72. I. Feng and H. Uhlig, J.Appl. Mech., 21, 395 (1954).

73. G. Butler and E. G. Stroud, "The Influence of Movement and Temperature on the Corrosion of Mild Steel. II. High Purity Water," J. App.1. Chem., 15, 325 (1965).

74. B. J. Milleville, "The Case for Higher Velocities in Feedwater Piping," Proc. Am. Power Conf. , 30, 475 (1968).

75. W. Stumm and G. F. Lee, "The Chemistry of Aqueous Iron," Sonderabdruck aus Schweizerische Zeitschrift fur Hydrologie, Birkhaüser Verlag Basel 22 (1960). 
76. P. J. Sereda, "Weathering Factors Affecting Corrosion of Metals," Corrosion in Natural Environments, ASTM STP 588, American Society for Testing and Materials, 7-22 (1974).

77. Anonymous. "Corrosiveness of Various Atmospheric Test Sites as Measured by Specimens of Steel and Zinc," Metal Corrosion in the Atmosphere, ASTM STP 435, American Society for Testing and Materials (1968).

78. I. L. Rozenfeld, Atmospheric Corrosion of Metals, National Association of Corrosion Engineers, Houston Texas, 187-200 (1972).

79. Fred H. Haynie, "The Economics of Clean Air in Perspective," Mater. Performance, 13, 33-38 (1974).

80. N. D. Tomashov, Theory of Corrosion and Protection of Metals; The MacMillan Co., New York, $(1966)$.

81. K. R. VanHorn (Ed.), Aluminum, 1, American Society of Metals, 209 (1967).

82. G. Wranglen, An Introduction to Corrosion and Protection of Metals; Halstead Press (John Wiley), New York, (1972).

83. W. K. Boyd, F. W. Fink, "Corrosion of Metals in the Atmosphere"; MCIC-74-23, Battelle Memorial Institute, (1974).

84. Z. A. Foroul is and M. J. Thubrikar, "On the Kinetics of the Breakdown of Passivity of Pre-anodized Aluminum by Chloride Ions," J. Electro. Soc. 122, 1296-1300 (1975).

85. H. Kaesche, "Pitting Corrosion of Aluminum and Intergranular Corrosion of Aluminum Alloys," NACE Conference on Localized Corrosion, Williamsburg, VA, NACE-3, 516 (1974).

86. F. I. Mr.Geary, T. 1. Sımmersnn and W. H. Ailnr, ilr., "Atmnspheris. Exposure of Nonferrous Metals and Alloys--Aluminum: Seven-Year Data," Metal Corrosion in the Atmosphere, ASTM STP 435, American Society for Testing and Materials, 141 (1968).

86a. W. H. Ailor, "Seven-Year Exposure at Point Reyes, California," Corrosion in Natural Environments, ASTM STP 588, American Society for Testing and Materials, 75-81 (1974).

87. M. 0. Speidel, "Stress Corrosion Cracking of A1 Alloys," Met. Trans. 6A, Apri1, 631 (1975).

88. H. H. vonCleve, "Comparison of Different Combinations of Wet and Dry Cooling Towers," ASME 75-WA/Pwr 10, 1975.

89. E. T. Wanderer, Application Engineer, Aluminum Company of America, Personal Communication, 1976. 
90. M. W. Larinoff, Vice President, Hudson Products Corporation, Personal Communication, 1976.

91. J. D. Swan and M. E. Komp, U.S. Steel Research Laboratory, Monroeville, PA, Personal Communication, April 18, 1975.

92. W. C. Patterson and J. E. Hal1, "Batch Hot-Dip Aluminizing," SAE 700448, 1970.

93. R. J. Schmitt and J. H. Rigo, "Alumidum-Coated Steel - A Product With Corrosion Resistance and Heat Resistance," Mater. Prot. and Perf., $5,(4), 46$ (1966).

94. R. A. Legault, A. G. Preban, "kinetlcs of the Almuspheric Currusiun of Low Alfoy Steel in an Industrial Atmosphere," Corrosion, 31 (4) 117, (Apri1 1975)

95. H. H. Uhlig, "Stress Corrosion Cracking," Fracture, Academic Press, New York, 645 (1971).

96. F. H. Haynie and J. B. Upham, "Correlation Between Corrosion Behavior of Steel and Atmospheric Pollution Data," Carrosion in Natural Environments, ASTM STP 558, American Society for Testing and Materials, 33-51 (1974).

97. W. H. McAdams, Heat Transfer, McGraw-Hil1, New York, (1942).

98. W. E. Berry, F. W. Fink, BCL Memo to A. B. Johnson, Jr. June 16, 1975, Subject: Corrosion of Candidate DCT Materials.

99. H. Guttman and P. J. Sereda, "Measurements of Atmospheric Factors Affecting the Corrosion of Metals," ASTM STP-435 American Society for Testing and Materials, 326 (1968).

100. J. M. Popplewel1 and T. V. Gearing, "Stress Corrosion Resistance of Some Copper Base Alloys in Natural Atmospheres," Corrosion 31 (8), 279 (August 1975).

101. Glen Nishimura, "Hot Dip Galvanizing, Process, Progress and Potential," Paper No. 72, Corrosion/75, Toronto, Canada, Apri1, 1975. Nvailable from National Association of Corrosion Engineers, Box 1499, Houston Texas, 77001 .

102. Anonymous, "Study of Dry-Type Cooling Towers and Their Application to Large Nuclear Power Plants," Catalytic, Inc. COD-2391-1, 1974.

103. B. Davis, President, GEA Air Exchangers, Inc., Personal Communication, 1975.

104. F. H. Cocks, Editor, Manual of Industrial Corrosion Standards and Control, American Society for Testing and Materials, ASTM STP-534, 1973. 


\section{ACKNOWLEDGEMENTS}

We gratefully acknowledge the following individuals for their review of the manuscript and helpful suggestions: Dr. Robert L. Dillon, Dr. Brent C. Fryer, and Dr. Benjamin M. Johnson. Also, we deeply appreciate the assistance of $\mathrm{Mr}$. Robert $\mathrm{C}$. Lawrence in gathering operational experience data from several industrial contacts.

We express appreciation also to the firms which provided data with regard to their experiences with the operation of dry-cooled equipment.

We are grateful to the following firms for helpful information and review of the report:

Aluminum Company of America .

American Hot Dip Galvanizers Association, Inc.

Battelle Columbus Laboratories

Copper Development Association, Inc.

Ecodyne, Cooling Products Division

Ecodyne, MRM Division

GEA - Gesellschaft für Luftkondensation, m.b.H.

Hudson Products Corporation

Kaiser Aluminum and Chemical Corporation

Marley Cooling Tower Company

Niagara Blower Company

Reynulds Metals Comilianiy

Scovill Manufacturing Company

United States Steel Corporation Research Laboratory

Wean United, Inc.

Wisconsin Electric Power Company

Wyodak Resources Development Corporation

Other firms which contributed to the report have chosen not to be identified for proprietary reasons. 


\section{APPENDICES}

\subsection{DRY COOLER OPERATING EXPERIENCE}

The following questionnaire was sent to several natural gas transmission companies to evaluate the severity of various aerial cooler problems. To date (March 1976) three companies have responded, with one of these companies sending data for a specific compressor station as well as data for the company at large. The results of this questionnaire survey to this point are summarized below. (Company designations compare with those in Table 2 of the main text)

- How dn youl ratee the severity nf the following nrnhiems with aprial coolers? (See rating scale below)
a) Vibration - . - . . . . . . . -
b) Finned tube corrosion (air side)
c) Tube corrosion (internal)
d) Tube scaling or fouling (internal)
e) Fin fouling (air side)
f) Fan blade failure : - . . - . . . . - -
g) Fan motor failure - - . - . - . - . -
h) Gear box failure _... - . . . . -
i) Freezing - . - . . . . . . . . -
j) Hail damage - . - . . . . . . . -
k) Hot air recirculation - - - . - - - -
1) Environmental impact - . . . . . -
Problem Severity Rating: 0 - Never 2 - Frequent
1 - Occasional 3 - Severe

- Please comment on the units which had problems with severity ratings of 1 or greater, specifying a) the age of the units, b) the location of the units, c) application in which the units are used, d) type of environment, e) cause of the problems, f) your solution to the problems, and $g$ ) other pertinent comments. Please use an additional sheet if necessary. 


\section{Problem Severity Ratings}

\section{Company A, General A, Specific Station E $E$}

\section{Problems:}

Vibration

Finned Tube Corrosion (air-side)

Tube Corrosion (internal)

Tube Scaling or Fouling (internal)

Fin Fouling (air-side)

Fin Blade Failure

Fan Motor Failure

Gear Box Failure

Freezing

Hail Damage

Hot Air Recirculation

Environmental Impact

other

$\begin{array}{lllll} & 1 & 1 & 0 & 1 \\ \text { (int) } & 1 & 0 & 0 & 0 \\ & 0 & 0 & 1 & 1 \\ & 1 & 1 & 1 & 1 \\ & 1 & 2 & 0 & 1 \\ & 1 & 1 & 0 & 0 \\ & 1 & 1 & 1 & 1 \\ & 0 & 0 & 1 & 0 \\ & 1 & 1 & 1 & 0 \\ & 1 & 0 & 1 & 0 \\ & 1 & 2 & 0 & 1 \\ & 1 & 0 & 0 & 0 \\ & 0 & 0 & 0 & 0\end{array}$

\section{Comments}

Company A. Vibration is due to loose supports and unbalanced fans. Occasional finned tube corrosion (air-side) is due to bad atmospheric conditions, specifically sulfur contamination in a marine environment. Tube scaling or fouling (internal) occurs with horizontal engines and is due to oil leakages into the circulating water and bacteria. Fin fouling (airside is by dirt, pollen, insects, etc.; the fins are cleaned with water or steam detergent. Fan blade failure is due to bad blades. Fan motor failure is due to bad motors and poor maintenance. Freezing has occurred in cold climates when antifreeze was not used and circulation stopped. Hot air recirculation has been a problem in some old forced draft units. 
Company E. The most frequent problems with internal tube corrosion have occurred in coils in engine jacket water, oil cooling water and steam condensing service. Some fan motor failures due to bearing failures have been experienced. Gear box failures have occurred due to shock loads and loss of lubrication from leaking seals. In some cases these are being replaced with larger size gear boxes. Some freezing problems have been experienced in coils in steam condensing service. In some installations, this problem has been solved by installing louvers on top of the coils or the sides of the fin fan structure or both. In some installations automatically controlled, variable pitch fan blades are used. Hail screens and/or louvers are used on top of the coil sections to protect the fins from hail damage.

Company F. Every four months, bearings are greased on motors, fan drives and gearboxes; and vibration levels are checked. Repairs are made as required, which is seldom. Tube fouling, scaling and currosiun dre nul siynificant problems. A few tubes have been replaced and others plugged on older units. The leaks are generally on water coolers and are normaliy confined to the area where the tube connects to the header. Most cooler fins are cleaned with compressed air each winter, which keeps them operating efficiently. 
10.2 COST OF CANDIDATE DCT MATERIALS

P. A. Ard, Battelle, Pacific Northwest Laboratories

Current (September 1975) materials cost data have been collected by PNL from the following tubing suppliers:

Copper-base alloys: Bridgeport Brass Co.

Aluminum 6061-T6

and 3003-H14: A7coa

Aluminum 3003-0: $\quad$ Tube Sales of Seattle

Carbon Steel: Kilsby Tube

Babcock \& Wilcox

Titanium: Timet

The material cost data for candidate dry cooling tower tubing materials are shown in Table B-1. All costs are FOB for large quantities $(\geq 50,000 \mathrm{ft})$ of tubing in 30-foot lengths. In general, these data can be applied to an equation of the form:

$$
\begin{aligned}
C_{t} & =C_{\ell m}\left(W_{\ell}\right)+C_{\ell}^{\prime} \\
\text { where } C_{t} & =\text { total tubing cost, } \$ / \mathrm{ft} \\
C_{\ell m} & =\text { material cost, } \$ / 1 \mathrm{~b} \\
W_{\ell} & =1 \mathrm{~b} / \mathrm{ft}=12 \pi \mathrm{P}_{\ell} D_{\ell}{ }^{*} \\
C_{\ell}^{*} & =\text { fixed cost, } \$ / \mathrm{ft} \\
& * P_{\ell}=\text { density, } 1 \mathrm{~b} / \mathrm{in}^{3} \\
D_{\ell} & =0 \mathrm{D}, \text { inches } \\
T_{\omega} & =\text { wall thickness, inches }
\end{aligned}
$$

to obtain total cost of tubing over a range of outșide diameters and wall thicknesses.

Total cost $\left(C_{t}\right)$ is plotted against wall thickness for one-inch tubing of seven candidate materials in Figure B-1. 
Schleithoff* reported costs of various condenser tubing ilaterials in Germany. Except for Type 304 stainless steel he reported higher costs relative to admiralty. His figures are compared with the data collected by PNL, using admiralty as the base, in Table B-2.

TABLE B-T. Linear and Condenser Tubing Costs and Densities

\begin{tabular}{|c|c|c|c|c|}
\hline Material & $\begin{array}{c}\text { ASTM } \\
\text { Specification } \\
\end{array}$ & $\underline{c}_{\ell}^{\prime}(\$ / f t)$ & $\underline{c}_{\ell m}(\$ / \#)$ & $\underline{P}_{l}\left(\# /\right.$ in. $\left.{ }^{3}\right)$ \\
\hline Admiràlity (443) & $B-111$ & 0 & 1.30 & 0.308 \\
\hline Copper & $B-111$ & 0 & 1.34 & 0.323 \\
\hline $\mathrm{Cu}-10 \mathrm{Ni}$ (706) & $B-111$ & 0 & 1.52 & 0.323 \\
\hline $\mathrm{Cu}-30 \mathrm{Ni}(715)$ & $B-111$ & 0 & 1.83 & 0.323 \\
\hline 6061-T6 Al & B-234 & 0.08 & 1.40 & 0.0975 \\
\hline 3003-H14 Al & $B-234$ & 0.04 & 1.36 & 0.0975 \\
\hline 3003-0 A1 & $B-210$ & 0.05 & 1.04 & 0.0975 \\
\hline Steel (seamless) & $A-179$ & 0.38 & 0.44 & 0.284 \\
\hline Steel (welded) & $A-214$ & 0.12 & 0.32 & 0.284 \\
\hline $304 \mathrm{~S} / \mathrm{S}$ (welded) & $A-249$ & 0.20 & 1.63 & 0.29 \\
\hline litanium Gràde 1 & $B-338$ & 0.15 & 7.60 & 0.163 \\
\hline Titanium Grade 2 & $B-338$ & 0.10 & 7.00 & 0.163 \\
\hline
\end{tabular}

TABLE B-2. Relative Costs of Condenser Tubing Materials

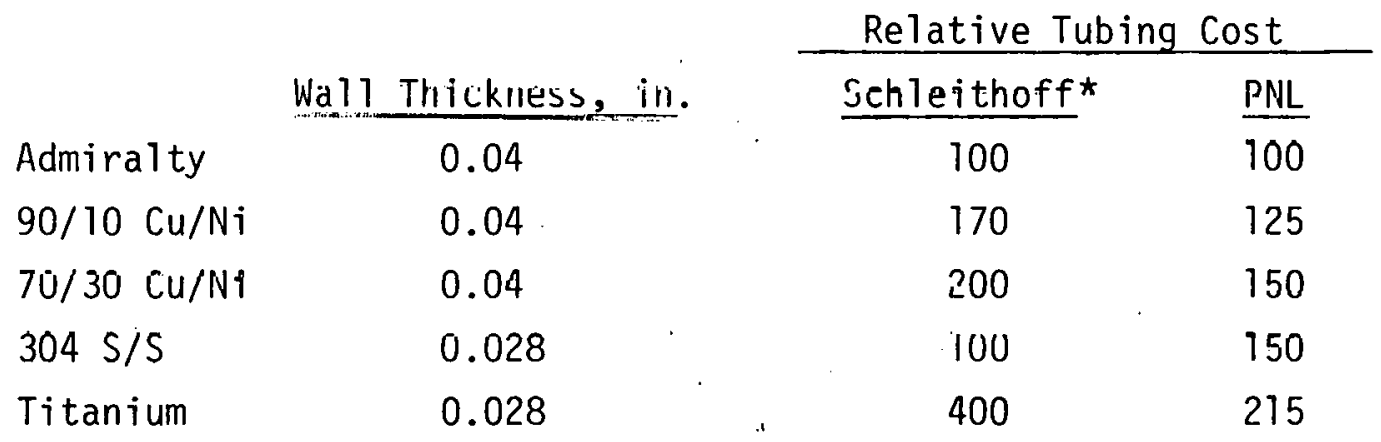

\footnotetext{
*K. Schieithoff, "Engineering Experience - German Utility Industry," Seminar on the Performance of Condensers in Nuclear and Fossile Power Plants, Columbus, OH (1975).
} 


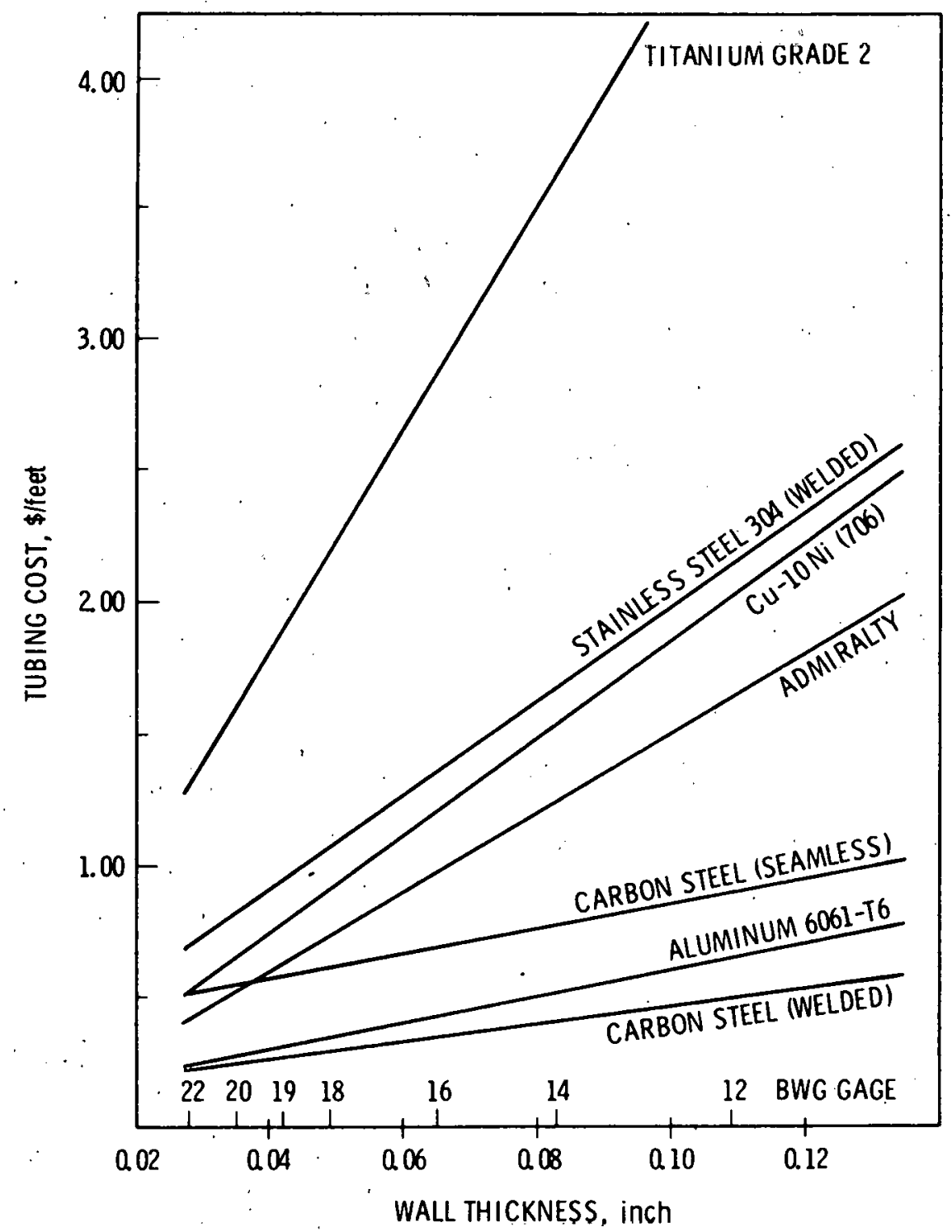

FIGURE B-1. Tubing Costs Versus Wal1 Thickness 


\subsection{WATER TREATMENT COSTS}

Following are tables which show the cost, in 1975 dollars, of treating raw water of varying quality to various purity levels. Table $c-1$ shows the capital, operating and total costs (in terms of $\$ / 1000$ gal) of a three-mgd*treatment plant. Data are given for five raw water types and four treatment levels, which are defined in Tables $\mathrm{C}-2$ and: $\mathrm{C}-3$.

As these data show, the cost of treating water varies widely and depends on the quality of the raw water and the level of treatment desired. Columbia River water can be treated for potable service for a cost of about $25 \$$ per 1000 gallons; if this water is to be treated for use as boiler feedwater, the cost would be about $81 \$$ per 1000 gallons. Similarly, a fairly hard surface water with a high level of suspended solids will cost about $44 \phi$ per 1000 gallons for treatment to potable quality and about $\$ 1.17$ per 1000 gallons for treatment to boiler feedwater quality.

The data which provide the basis for the cost figures in Table $C-1$ were provided by Dr. John $\dot{S}$. Nordin, Betz Environmental Engineers, Inc.

* million gallons per day. 
TABLE C-1. Water Treatment Costs, 3-MGD Treatment Plant (1975 Dollars)

\begin{tabular}{|c|c|c|c|c|c|}
\hline $\begin{array}{l}\text { Desired } \\
\text { Quality } \\
\end{array}$ & $\begin{array}{r}\text { Raw } \\
\text { Water } \\
\text { Type } \\
\end{array}$ & $\begin{array}{l}\text { Capital } \\
\text { Cost, } \\
\$ \times 10^{-5} \\
\end{array}$ & $\begin{array}{c}\text { Capital } \\
\text { Cost,* } \\
\$ / 1000 \text { gal } \\
\end{array}$ & $\begin{array}{c}\text { Operating } \\
\text { Cost, } \\
\$ / 1000 \text { gal } \\
\end{array}$ & $\begin{array}{r}\text { Total } \\
\text { Cost, } \\
\$ / 1000 \text { gal } \\
\end{array}$ \\
\hline \multirow[t]{5}{*}{ Potable } & $A_{1}$ & 4.4 & 0.087 & 0.162 & 0.249 \\
\hline & $\mathrm{A}_{2}$ & 8.6 & 0.171 & 0.204 & 0.375 \\
\hline & $B$ & 9.6 & 0.191 & 0.240 & 0.431 \\
\hline & C & 10.1 & 0.201 & 0.234 & 0.435 \\
\hline & D & 1.7 & 0.034 & 0.061 & 0.095 \\
\hline \multirow[t]{5}{*}{ Pure } & $A_{1}$ & 4.4 & 0.087 & 0.162 & 0.249 \\
\hline & $A_{2}$ & 8.6 & 0.171 & 0.204 & 0.375 \\
\hline & $B$ & 17.6 & 0.350 & 0.352 & 0.702 \\
\hline & C & 10.1 & 0.201 & 0.234 & 0.435 \\
\hline & D & 19.9 & 0.395 & 0.454 & 0.849 \\
\hline
\end{tabular}

High

Purity

$A_{1}$
$A_{2}$
$B$
$C$
$\vdots$

13.4

0.266

0.441

0.707

17.7

0.352

0.461

0.813

B $\quad 17.6$

0.350

0.588

0.938

C 21.1

0.419

0.630

1.049

23.4

0.465

0.652

1.117

$\underline{\text { U1tra }}$

\begin{tabular}{|c|c|c|c|c|c|}
\hline \multirow[t]{3}{*}{ Pure } & $\mathrm{A}_{1}$ & 15.9 & 0.316 & 0.496 & 0.812 \\
\hline & $\mathrm{A}_{2}$ & 20.2 & 0.401 & 0.516 & 0.917 \\
\hline & $B$ & 20.1 & 0.399 & 0.643 & 1.042 \\
\hline & C & 23.6 & 0.469 & 0.704 & 1.173 \\
\hline & $D$ & 23.4 & 0.465 & 0.700 & 1.165 \\
\hline
\end{tabular}

* Fixed charge rate $=17.4 \% ;$ Plant capacity factor $=80 \%$ 


\section{TABLE C-2. Raw water Types}

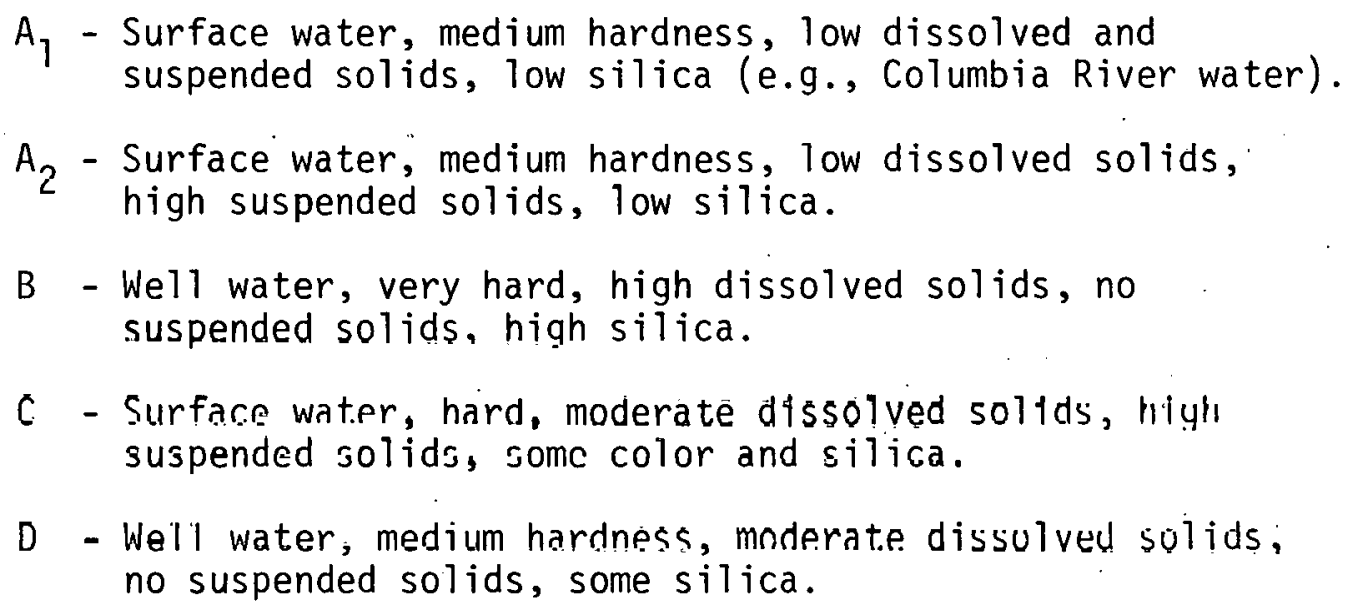

TABLE C-3. Treatment Levels

Potable Fure High Purity Ultra Pure

$\mathrm{pH}$
6. . - -9.0

$6.5-7.5$

$6.5-7.5$

$6.5-7.5$

Hardness,
mg/liter
as $\mathrm{CaCO}_{3}$

$50-150$

$20-40$

$2-4$

$<0.05$

Iron, mg/liter $\quad \leq 0.3$

$\leq 0.1$

$<0.1$

$<0.01$

Silica, mg/liter 10-20

2

$<0.1$

$<0.01$

Dissolved

Solids,

$100-250$

$50-100$

$5-10$

$<0.05$ 


\section{DISTRIBUTION}

No. of

Copies

OFFSITE

A. A. Churm

ERDA Chicago Patent Group

U.S. ERDA

9800 So. Cass Ave.

Argonne, IL 60439

U.S. ERDA Office of Assistant General Counsel for Patents Washington, DC 20545

ERDA Technical Information Center

4 W. F. Savage

Advanced Concepts

Evaluation Branch

ERDA Division of Nuclear Research and Application

Washington, DC 20545

G. W. Cunningham

Acting Deputy Director

for Technology

Division of Nuclear Research and Application

U.S. ERDA

Washington, DC 20545

A. J. Pressesky

Acting Assistant Director

for Technology

Division of Nuclear Research and Application

U.S. ERDA

Washington, OC 20545

G. A. Newby

Acting Director

Division. of Nuclear Research and Application

U.S. ERDA

Washington, DC 20545
No. of

Copies
D. H. Groelsema

Chief, Engineering and

Components Development Branch

ERDA Division of Nuclear

Research and Application

Washington, DC 20545

T. Beresovski

Chief, Advanced Concepts

Evaluation Branch

ERDA Division of Nuclear

Research and Application

Washington, DC 20545

B. R. Dickey

Allied Chemical Company

550 2nd St.

Idaho Falls, ID 83401

J. S. Joyce

Allis-Chalmers Power Systems, Inc.

1135 So. 70th St.

West Allis, WI 53214

E. T. Wanderer

A) uminum Company of America

Alcoa Technical Center

Alcoa Center, OH 45069

H. J. Janzon

American Electric Power

2 Broadway

New York, NY 10004

T. Woods

Arizona Public Service Co.

2121 W. Cheryl Dr.

Phoenix, AZ 85021

J. P. Budliger

Battele-Geneva

7 Route De Drizi

¡227 Geneva, SWITLERLANU 
No. of

Copies

K. Simhan

Battelle Institute eV. 6000 Frankfurt/Main 90

Postfach 900160

GERMANY

G. C. Creel

Baltimore Gas \& Electric Co. Gas \& Electric Bldg.

Baltimore, MD 21203

E. Schinner

Baltimore Nircoil Co., Inc.

P.0. Box 7322

Baltimore, MD 21227

G. E. Collins

Research Cottrell

Hamon Cooling Tower Division

P.0. Box 750

Bound Brook, NJ 08805

W. Kals

Niagara Blower

405 Lexington Ave.

New York, NY 10017

M. W. Peterson

Babcock \& Wilcox

Fossil Power Division

20 So. Van Buren

Barberton, $\mathrm{OH} 44203$

W. Keel

Texas Electric Service Co.

115 W. Seventh St.

Fort Worlh, TX 76102

R. J. Meyer

Louisiana Power \& Light Co.

142 Delaronde St.

New Orleans, LA 70174

S. Ragone

Virginia Electric \& Power Co.

$700 \mathrm{E}$. Franklin St.

Richmond, VA 23261
No. of

Copies

H. T. Wilson

Tampa Electric Co.

P.0. Box 111

Tampa, FL 33601

P. Leung

Bechtel Corporation

P.0. Box 60860

Terminal Annex

Lo's Angcles, CA 90060

G. R. Retti

Bechtcl Corporation

P.0. Box 3965

San Francisco, CA 94119

J. P. Rossie

R. W. Beck \& Associates

400 Prudential Plaza

Denver, CO 80202

W. J. Westre

Black Hills Power and Light Co.

H.U. Box 1400

Rapid City, SD 57701

J. Sell

Carolina Power \& Light Co.

336 Fayet.tesville St.

Raliegh, NC 27602

J. Morse

Catalytic Construction Corp.

P.0. Box 11402

Charlotte, NC 28029

R. H. Holyuak

Commonwealth Edison

One First Plaza

P.0. Box 767

Chicago, IL 60690

C. L. Newirlan

Consolidated Edison Co.

of New York, Inc.

4 Irving Place

New York, NY 10003 
No. of

Copies

F. K. Moore

Cornell University

Ithaca, NY 14850

R. C. Haberski

Curtiss Wright Corp.

One Passaic St.

Wood Ridge, NJ 07075

S. K. Blackley

Duke Power Co.

P.O. Box 2178

Charlotte, NC 28201

J. K. Swindt

Ecodyne Cooling Products Co.

San Rosa, CA 95403

J. Maulbetsch

Electric Power Research Institute

3412 Hillview Ave.

P.0. Box 10412.

Palo Alto, CA: 94304

L. Geller

Empire State Electric Energy Research Corp.

1250 Broadway

New York, NY. 10001

F. H. Rainwater

Environmental Protection. Agency

Pacific Northwest Water

Laboratory

200 S.W. 35th St.

Corvalitis, OR 97330

A. M. Rubin

Franklin Institute

I wentieth \& Parkway

Philadelphia, PA 19103

B. Davis

GEA Airexchangers, Inc.

46 Worthington Dr.

Maryland Heights, MD 63043
No. of

Copies

D. A. Nelson

General Atomics

P.0. Box 81608

San Diego, CA 92138

E. H. Miller

General Electric Co.

Large Steam Turbine Division

300 Nott St.

Schenectady, NY 12301

J. F. Sebald

Gilbert Associates, Inc.

525 Lancaster Ave.

Reading, PA 19603

J. E. Taboric

Heat Transfer Research Inc.

1000 S. Fremont Ave.

Alhambra, CA 91802

E. C. Smith

Hudson Products

6855 Horwin Dr.

Houston, TX 77036

M. W. Larinoff

Hudson Products

6855 Horwin Dr.

Houston, TX 77036

C. Rocco

Italimpianti - Societa

Italiana Impianti p.a.

Piazza, Piccapietra 9

18121 Genoa, ITALY

J. L. Mulloy

Los Angeles Department of Water and Power

111 N. Hope St.

Los Angeles, CA 90012

R. Landon

Marley Co.

5800 Fox Ridge Dr.

Mission, KS 66202 
No. of

Copies

L. R. Glicksman

Massachusetts Institute of Technology

77 Massachusetts Ave.

Cambridge, MA 02139

W. G. Hoydysn

New York University

University Heights

New York, NY 10453

R. H. Meyer

Northeast Utilities

P.0. Box 270

Hartford, CT 06101

F. F. Mautz

Pacific Gas \& Electric

77 Beale St.

San Francisco, CA 94106

P. G. Humphries

Pacific Power \& Light Co.

Public Service Bldg.

Portland, OR 97204

T. Rozenman

PFR Engineering Systems

$1417 \mathrm{~S}$. Georgia St.

Los Angeles; CA 90015

A. C. Smith Power Generation Cooling,
Systems

4714 52nd St. S.

Seattle, WA 98118

R. F. Walker

Public Service of Colorado

5900 E. 39th Ave.

Denver, CO 80207

E. D. Kist

Public Service of New Mexico

Corporate Planning Dept.

Albuquerque, NM 87103
No. of

Copies

B. Caruthers

Reynolds Aluminum Co.

Reynolds Metallurgical Research Laboratory

Richmond, VA 23261

Prof. Ing. Carlo Roma

Piazza delle Muse 8

Rome, ITALY

R. G. Lacy

San Diego Gas \& Electric

101 Ash St.

San Diego, CA 92107

R. L. Skone

Seattle City Light

1015 Third Ave.

Seattle, WA 98104

J. Rasband

Southern California Edison 2244 Walnut Grove Ave.

Rosemead, CA 91770

P. Sporn

Consultant Englneer

74 Trinity Pl., Suite" 511

New York, NY 10006

J. Y. Parce

Stearns and Roqers

700 S. Ash St.

Denver, CO 80222

D. H. Guild

Slune \& Webster [ngineering Corp.

225 Franklin St.

Boston, MA 02107

G. J. Kidd

Union Carbide Corp.

ORGDP - K-25

P.0. Box. D

Oak Ridge, TN 37803 
No. of

Copies

G. A. Engelson

United Engineers \&

Constructors

IVB BIdg.

1700 Market St.

Philadelphia, PA 19105

J. F. Kennedy

University of Iowa

Hydraulic Research Institute

Iowa City, IA 52240

L. P: Davis

Dept. of Mechanical

Engineering

Oregon State University

Corvallis, OR 97330

C. E. Wicks

Dept. of Chemical Engineering

Oregon State University

Corvallis, OR 97330

J. H. Hutchinson

Utah Power \& Light

1407 W. N. Temple

Salt Lake City, UT 84103

G. H. Soule West Associates

Sierra Pacific Power Co.

100 E. Moana Lane

Reno, NV 89510

K. A. Oleson

Westinghouse Electric Corp.

Steam Turbines Division

Lester Branch

P.0. Box 9175

Philadelphia, PA 19113

G. J. Silvestri

Westinghouse Electric Corp.

Steam Turbines Division

Lester Branch

P.0. Box 9175

Philadelphia, PA 19113
No. of

Copies

B. W. Walters

Tennessee Gas Transmission

P.0. Box 2511

Houston, TX 77001

L. C. Unger

Transcontinental Gas Pipeline Corp.

P.0. Box 1396

Houston, TX 77001

J. W. Cronenberg

El Paso Natural Gas

600 Building of the Southwest

Midland, TX 79701

W. Berry

Battelle Columbus Laboratories

505 King Avenue

Columbus, $\mathrm{OH} 43201$

E. H. Phelps

U.S. Steel Research Laboratory

125 Jamison Lane

Monroeville, PA 15146

J. S. Slotnik

Ecodyne Corp.

MRM Division

607 First Street S.W.

Massillion, $\mathrm{OH} 44646$

E. G. Bauer

Wean United, Inc.

1400 Grace Ave. N.E.

P.0. Box 1769 Station A

Canton, $\mathrm{OH} 44705$

G. Rogers

Scovill Manufacturing Company

99 Mill Street

Waterbury, CT 06720

D. Brodine

Ford Motor Company

P.0. Box 177

Lima, $\mathrm{OH} 45802$ 
H. G. Gillit

Northwest Pipeline Corp.

275 East $200 \mathrm{~S}$.

Salt Lake City, UT 84111

T. Summerson

Kaiser Aluminum

P.0. Box 870

Pleasanton, CA 94566

K. Lehner

Wisconsin Electric Power to.

231 W. Michigan Ave.

Mi Twaukee, WI 53203

R. S. French

Copper Development

Assoc., Inc.

405 Lexington Ave.

New York, NY 10017

M. D. Orton

Pacific Gas \& Electric Co.

77 Beale St.

Room 2844

San Francisco, CA 94106

G. H. Horne

Standard 0 il Co.

P.0. Box 3069

San Francisco, CA 94119

R. E. Moore

Texas Eastern Transmission Corp.

P.0. Box 1612

Shreveport, LA 71130

D. Tonini

American Hot Dip

Galvinizers Assoc., Inc.

1000 Vermont Ave. N.W.

Washington, DC 20005

J. S. Nordin:

Betz Environmental Engineering

One Plymouth Meeting Mal1

Plymouth Meeting, PA 19462
D. K. Traverse

Southern California Gas Co.

Box 3249 Terminal Annex

Los Angeles, CA 90051

B. Hadley

Michigan Wisconsin Pipeline Co.

1 Woodward AVenue

Detroit, MI 48226

R. I. Lindberg

Reyilulds Meldis Company

Fourth and Canal Streets

Richmond, VA 23219

ONSITE

ERDA Richland Operations Office Program Division

B. J. Melton

Westinghouse Hanford Company Hanford Engineering Development Laboratory

J. F̄letcher

87. Battelle-Northwest

R. T. Allemann

1. W. Ambrose

H. A. Ard

J. W. Currie

D. E. Deonigi

J. G. Desteesse

R. L. Dillon

D. W. Uragnich

D. W. Faletti

J. W. Finnigan

B. C. Fryer

C. H. Henager

A. B. Johnson, Jr. (10)

W. S. Kelly

R. S. Kemper

C. J. Knoll

Distr-6. 
No. of

Copies

Battelle-Northwest - (Cont'd)

W. V. Loscutoff

R. P. Marshall

D. E. Olesen

Y. Onishi

L. T. Pedersen

D. R. Pratt (10)

H. C. Riches

J. B. Schuette

G. C. Smith

J. S. Stoakes

A. M. Sutey

D. S. Trent

M. Vagins

R. A. Waiter

R. L. Watts

R. D. Widrig

R. K. Woodruff

G. E. Zima

File - B. M. Johnson (30)

Technical Information (3)

Technical Publications (2)

(1) 